
\title{
Rhythms of the rituals and
}

Afro-Atlantic World

Edited by Mamadou Diouf and Ifeoma Kiddoe Nwankwo 
Rhythms of the Afro-Atlantic World 



\section{Rhythms of the \\ Afro-Atlantic World}

Rituals and Remembrances

EDITED BY

MAMADOU DIOUF AND

IFEOMA KIDDOE NWANKWO

The University of Michigan Press 
Copyright $\odot$ by the University of Michigan 2010

All rights reserved

Published in the United States of America by

The University of Michigan Press

Manufactured in the United States of America

@ Printed on acid-free paper

$\begin{array}{llllllll}2013 & 2012 & 2011 & 2010 & 4 & 3 & 2 & 1\end{array}$

No part of this publication may be reproduced, stored in a retrieval system, or transmitted in any form or by any means, electronic, mechanical, or otherwise, without the written permission of the publisher.

A CIP catalog record for this book is available from the British Library.

Library of Congress Cataloging-in-Publication Data

Rhythms of the Afro-Atlantic world : rituals and remembrances / edited by Mamadou Diouf and Ifeoma Kiddoe Nwankwo.

p. $\quad \mathrm{cm}$.

Includes bibliographical references and index.

ISBN 978-0-472-07096-1 (acid-free paper)

1. Popular music-Caribbean area-History and criticism.

2. Blacks-Caribbean area-Music-History and criticism. 3. DanceCaribbean area-History. 4. Hip-hop-Africa. I. Diouf, Mamadou. II. Nwankwo, Ifeoma Kiddoe.

ML3486.A1R49 2010

$780.89^{\prime} 96-\mathrm{dc} 22$

2010004464

ISBN 978-0-472-02747-7 (e-book) 


\section{Contents}

INTRODUCTION

Mamadou Diouf and Ifeoma Kiddoe Nwankwo

\section{PART ONE: RELIGION}

The Economic Vitamins of Cuba: Sacred and Other Dance Performance

YVONNE DANIEL

Performing Pentecostalism: Music, Identity, and the Interplay of Jamaican and African American Styles

MELVIN L. BUTLER

"The Women Have on All Their Clothes": Reading the Texts of Holy Hip-Hop

DEBORAH SMITH POLLARD

\section{PART TWO: DANCE}

Rhythmic Remembrances

YVONNE DANIEL

Citizenship and Dance in Urban Brazil: Grupo Corpo, a Case Study

LUCÍA M. SUÁREZ

Muscle/Memories: How Germaine Acogny and Diane McIntyre

Put Their Feet Down

SUSAN LEIGH FOSTER

"To Carry the Dance of the People Beyond": Jean Léon Destiné,

Lavinia Williams, and Danse Folklorique Haïtienne 


\section{PART THREE: CONTEMPORARY MUSIC}

Motherland Hip-Hop: Connective Marginality and African American Youth Culture in Senegal and Kenya

HALIFU OSUMARE

161

New York Bomba: Puerto Ricans, Dominicans, and a Bridge Called Haiti

RAQUEL Z. RIVERA

178

Talking Drums: Soca and Go-Go Music as Grassroots Identity Movements DEIDRE R. GANTT

200

Warriors of the Word: Rapso in Trinidad's Festival Culture

PATRICIA VAN LEEUWAARDE MOONSAMMY

Timba Brava: Maroon Music in Cuba

UMI VAUGHAN

Salsa Memory: Revisiting Grupo Folklórico y Experimental Nuevayorquino JUAN FLORES AND RENÉ LÓPEZ

Epilogue: Performing Memories-The Atlantic Theater of Cultural Production and Exchange

CARROLL SMITH-ROSENBERG 


\section{Introduction}

MAMADOU DIOUF AND IFEOMA KIDDOE NWANKWO

Located simultaneously inside and outside Western modernities and aesthetics, Afro-Atlantic peoples have used music and dance to continually represent and reinvent their multiple bases of identity-physically, emotionally, and intellectually. ${ }^{1}$ Through the two genres, these communities dramatize, articulate, and appreciate their historical narratives in relation to their African, European, and American genealogies. As venues for the staging of these dramas of contact, conflict, and synthesis, music and dance are crucial sites for the narration of Afro-Atlantic modernities as well as key arenas in which Black agency, creativity, and dominance are at once recognized by the West and claimed by AfroAtlantic people. ${ }^{2}$

Along with linked modes of religiosity, music and dance have also figured prominently in scholars' approaches to documenting the results of the multidimensional cultural contact brought about by the Atlantic slave trade. The focus of pioneers like Fernando Ortiz on these genres was not a coincidence but, rather, a recognition of the fact that Afro-Atlantic music and dance simultaneously carry history and memory within them and show the ways communities have blended past with present realities, yielding wholly new cultures. Widely considered to be the most visible contributions of African-descended communities to the making of the Atlantic world, music and dance have been identified, along with orality, not only as the main modes of occurrence and dissemination in the world of black culture but also as linked channels of black expressivity and presence in the world scene. ${ }^{3}$ African music is "always music for dance," and African dances are "polymorphic music, with the upper and the 
lower parts of the body appearing to move to two different, related clocks." Not only are they "pleasurable and erotic," but they are also powerful spiritual grammars and rituals of socialization, languages of interventions in nature and society, contributing to the expression of African religious and cultural beliefs and manifestations of and engagements with historical (dis)continuities. ${ }^{4}$

This unique collection of essays connects nations from across the Atlantic-Senegal, Kenya, Trinidad, Cuba, Brazil, and the United States, among others-highlighting contemporary popular, folkloric, and religious music and dance as living evidence of the ironically productive potential of this age of consumerist globalization, especially for Afro-Atlantic artists and communities. In this most recent era of financially driven flows of culture and peoples within and among the nations of the Atlantic, Afro-Atlantic music and dance have become prime commodities. As economic commodities they fatten the bank accounts of multinational media companies and well-positioned artists. As cultural commodities they are employed by individuals and communities to craft cultural and ideological weapons for their battles against colonialism and neocolonialism, governmental corruption, and the inequalities created and perpetuated by the same multinational/mercantile system that makes this transnational weaponry possible. Religion and religious cultural products are key commodities in the contemporary moment of globalization, commodities that inspire, illuminate, and disseminate approaches to defining and enacting community and citizenship. Along with secular music and dance, these traveling consumer products are constitutive elements of Afro-Atlantic communities' perceptions, expressions, and enactments of conceptions of identity, often even when they appear to be wholly local. As such, they exemplify what can be usefully termed "globalization creolization."

By tracking the continuous reframing, revision, and erasure of aural, oral, and corporeal traces, the contributors to Rhythms of the Afro-Atlantic World collectively argue that music and dance are living indices of a constant (re)composition and (re)mixing of local sounds, gestures, epistemologies, and memories. These multiple and intersecting itineraries are transformed by continuous movements across time and geography, becoming at once more local and more transnational while also representing African and diasporic communities' economies of knowledge about the Atlantic world-particularly around issues of citizenship, consumerism, and the social and political mission of arts and artists.

Scholars have long sought to map the circuits of Afro-Atlantic music and dance, tracing the travels and revisions of specific sounds, forms, and gestures 
among sites. With regard to the role of drums brought along (by slaves) from the African coast, ${ }^{5}$ in particular, Ned Sublette notes that they "allowed slaves to dance at a certain place on deck" during the Middle Passage and on "Sundays and holidays or even at break," because the planters "realized that dancing was important for-it is not an exaggeration to say-keeping the slaves alive." ${ }^{\circ} \mathrm{Al}-$ though both forms are vital, music has been accorded more attention than dance. As noted by Alexander G. Weheliye, music, more than dance, "has and still continues to function as one of the main channels of communication between the different geographical and cultural points in the African diaspora, allowing artists to articulate and perform their diasporic citizenship to international audiences and to establish conversations with other diasporic communities." The plethora of books and articles on African and African American music, more specifically on jazz ${ }^{8}$ as the embodiment of American music, ${ }^{9}$ is ample evidence of this perception.

This valuing is not new. Building on Frederick Douglass's identification of the magnetic and soul-stirring power of the "sorrow songs," as he termed them, ${ }^{10}$ W. E. B. Du Bois, in The Souls of the Black Folk, ${ }^{11}$ devotes "[an] unforgettable chapter to the songs created in the doldrums of slavery in order to give them a serious and proper interpretation, just as later Mr. Henry Edward Krehbiel in his Afro-American Folksong: A Study in Racial and National Music gave them their most serious adequate musical analysis and interpretation." ${ }^{12}$ Du Bois's musical interpretation focuses on songs that "are indeed the siftings of centuries" and on "music ... far more ancient than the words and in it," in which "we can trace here and there signs of development." ${ }^{13}$ According to Du Bois, music is the foremost accomplishment of the black humanity, ahead of slave labor and the various modes and rituals of black religiosity. ${ }^{14}$ Alain Locke, editor of The New Negro- "our first national book ... representing a unified community of national interests set in direct opposition to the general economic, political, and theological tenets of a racist land"15_dedicated an entire section to music and dance, with articles contributed by himself on Negro spirituals, by J. A. Rogers and Langston Hughes on jazz, and by Claude McKay and Langston Hughes on dance. ${ }^{16}$ This tradition has been upheld and revised by scholars and activists, such as Amiri (Leroi Jones) Baraka, ${ }^{17}$ who are interested in the connection to African forms and/or the transforming effect of colonial musical influence. Music and dance have been used to restore the sense of humanity and rootedness that slavery took away, while participating very powerfully in their reconfiguration and reinvention by modernist traditions.

Edouard Glissant, by adding "the gift of speech [orality] gesture and dance" 
as "forms of communication"18 to Du Bois's "three gifts" of music, labor, and spirit, illuminates the historical connection between music and dance and the interwoven dialogue about both forms embedded within discourses on African and African American identity, memory, and cultural expression. Negritude authors Aimé Césaire and Leopold Sédar Senghor have eloquently ascribed to music and dance the critical functions of defining Blackness and Black presence in the world stage together or separately. In addition to Du Bois's invitation to listen to the "souls of Black folks," 19 Senghor stresses their physical and corporeal exposition. They are not only sung but danced, blending sensuality and spirituality through rhythm; thus they have to be seen. For Senghor, rhythm is "the architecture of being, the internal dynamics that gives it form." He explains, "Rhythm is the vibratory shock, the force that, through the senses, strikes us to the root of our being and expresses itself in the most material, sensual ways: lines, surfaces, colors, volumes and architecture, sculpture and paintings, accents in poetry and music, movements in dance. But, in doing so, it orders all this concreteness toward the light of the spirit." ${ }^{20} \mathrm{In}$ conversation with $\mathrm{Du}$ Bois, ${ }^{21}$ Senghor opposes rhythm, considered the defining feature of African musical and dance practices, to the two significant attributes of Western music, harmony and melody, thereby connecting the gifts of work, music, and spirituality. He describes the physical, oral, and aural enactment of rhythm as "constructing the last and only vestiges of the corporeal, sonically folding the body into the voice and vice versa." "In this process of folding," he continues, "the ear is directed toward the sound process itself, that is, the way in which a black voice performs and constructs its corporeality."22

Paul Gilroy's The Black Atlantic: Modernity and Double Consciousness is credited by many scholars with inspiring a vibrant discourse on the narratives of selfhood, community, and race embedded in the cultural products born of the movement of people of African descent throughout the Atlantic. He attempts to account for the place of music in modern black culture, affirming it a privileged place in diaspora cultures through the interactions of the performers and the audiences, and the intimate relationships to modernity, "beyond ethnically coded dialogue." In addition to explicating the Atlantic dimensions of the work of intellectuals such as W. E. B. Du Bois, Richard Wright, and Martin Delany, Gilroy sought to pay particular attention to the import of the creations of musical artists such as Soul II Soul. Houston Baker, in Modernism and the Harlem Renaissance, explores how music and certain black vernacular oral expressions are inscribed in African American literary works, in particular how certain sounds are replayed in literary artifacts. The work of music historians 
and musicologists such as Robert Bennett, Ingrid Morrison, Elijah Wald, and Alexander G. Weheliye also reveals an increasing attentiveness to the musical products of the Black Atlantic. New approaches in literary as well as in music and dance studies are attempting to attend to the complexities of the transactions between instruments (including the body and the technology of production and dissemination of music), sites of performance, innovations and repetitions, audience, and commodification, as well as the politics of music and dance in different regions of the Atlantic. Much of the work, particularly that published by major presses, has centered on U.S. African American music or Cuban music and, to a lesser degree, on African, British Caribbean, and nonCuban Latino/Latin American music. Nevertheless, lacunae remain, particularly in terms of religious/ritual/spiritual music. In addition, monographs published on other forms of music are often nationally bounded.

Rhythms of the Afro-Atlantic World seeks to fill those persistent voids by foregrounding the traffic between and among communities, the cross-cultural and/or transnational movement of Afro-Atlantic cultural products, their consumption by other Atlantic communities, and the extent to which they result in new forms of and approaches to defining and enacting citizenship. This moment has made it possible for communities to be even more aware of the strategies that others are using to "talk back," so that even when a community creates and/or enacts a form that is "local," it still has within it elements born of a translocal awareness, whether the signs of that are easily recognizable or deeply embedded. Consequently, local forms cannot easily be cordoned off or definitively distinguished from global ones. It is not that the local or the nation are disappearing but, rather, that the national citizen himself /herself, like the national music or dance itself, is constituted in part by a historical and presentday transnational. The essays in this collection are case studies of modes and means of exchange in the contemporary Atlantic cultural marketplace, more specifically of those that serve as a way for populations to empower themselves, express their power, and move their struggles against local inequality forward. The transnational traffic, therefore, becomes a medium for the production of empowered citizenries. The developments in music and dance explored here, born of circum-Atlantic capital and consumer goods flows, are responses to, critiques of, and consciously crafted alternatives to the top-down contact made possible by this most recent era of globalization-markers of processes of globalization creolization. Lateral engagements create an alternate route map for commodity traffic, albeit cultural and ideological traffic, enriching the local rather than dominating or silencing it or making it unrecognizable. As such, 
they demand greater attention from scholars working to delineate Afro-Atlantic peoples' places in and responses to this contemporary moment of globalization, especially since these peoples were the core/basis of the previous era of major trans- and circum-Atlantic traffic. Being attentive to the sorts of lateral engagements addressed here allows further insight into their position visà-vis this contemporary one.

\section{THE ESSAYS}

For decades, the tracking of Africanisms and creolization, often through studies of religious practice (i.e., syncretism), has been fundamental to studies of Afro-Atlantic culture, particularly those done by Atlanticist historians and anthropologists (e.g., Sidney Wilfred Mintz and Richard Price's The Birth of African-American Culture and Edward Kamau Brathwaite's The Development of Creole Society in Jamaica). The essays in the first part of this volume illustrate the extent to which this era of globalization creates a multidirectional cultural and economic traffic in religious music and dance, fueling the creation of new forms of religious expression and new approaches to linking the religious and the secular, genres that cannot be as easily comprehended through traditional syncretism/Africanism models. They acknowledge the foundational significance of the earlier scholarship on religious syncretism, particularly the extent to which it helped to provide the language and conceptual tools for talking about the cross-cultural dynamism inherent in Afro-Atlantic religious and cultural expression, while also illustrating the ongoing and particular importance of religion to Afro-Atlantic peoples' attempts to reconcile their multiple cultural, epistemological, and psychological worlds and identities in this era of consumer culture globalization.

In her essay titled “The Economic Vitamins of Cuba,"Yvonne Daniel argues that African diasporic dance and music practices in the Caribbean are important parts of religious ritual but are also targeted economic commodities that many governments use to boost tourism. As evidence, she discusses the ways in which Cuban worshipers and dancers use their own African dance practices as a form of public display, as spiritual offering, and as a national "guardianship" of the orichas, while the performers are also keenly aware of the government's economic interest in these practices and so perform for tourists in order to aid Cuba's struggling economy. Additionally, the large numbers of instructional workshops and dance and music festivals held on the island have lured international students to Cuba, thus creating a subtourist group that also contributes 
greatly to the nation's economic welfare. Additionally, the revenue from students allows instructors access to foreign goods and helps students form important professional connections, a greater knowledge of Cuban culture, and more expertise in their art. Nevertheless, the seductive lure that ritual performances like dance hold for tourists has also created some social problems, like the rise in the sex trade, prostitution, and HIV/AIDS. Nevertheless, argues Daniel, ritual performances are part of a secularization process that is inherent in Cuban communism/socialism, and dance and music will continue to be used strategically by Cubans for the greater benefit the national government, foreign visitors, and themselves.

In contrast to Daniel's essay, Melvin L. Butler's contribution to this volume discusses the ways in which African American and Jamaican reggae-influenced music has been received and appropriated among Pentecostal Jamaicans at home and abroad. He argues that music coming from the United States to the island of Jamaica plays a complex and often contradictory role in how churchgoers identify themselves in relation to religious and cultural outsiders. For example, younger Jamaican Pentecostals are now drawn to African American gospel music styles, often characterizing them as "black," though not necessarily "Jamaican." In fact, for many urban congregations, African American gospel styles provide a means of expressing a "modern" Pentecostal aesthetic while counteridentifying against the "white" hymnody and "white-sounding" traditional Pentecostal music of earlier generations. At the same time, "black" styles are also associated with the traditional "clap-hand" choruses that are characteristic of indigenous musical genres like ska and dancehall. Despite their global and local cultural connections, some Jamaican preachers are vehemently opposed to either of these influences and criticize contemporary church practices, which they contend have strayed too far from those of traditional Pentecostalism. Butler argues that for them, worldliness, "African Americanness," and gospel reggae all seem to be interchangeable terms. For many Jamaican churchgoers, though, gospel music with African American and island influences is a means of expressing both religious authenticity and cultural distinctiveness. Additionally, for Pentecostals living abroad, it can often serve as a source of personal strength and a foundation for minority group consciousness, allowing Jamaicans to partake in cathartic acts of cultural solidarity and celebrate a common national identity, even when they are far away from home.

Deborah Smith Pollard's "The Women Have on All Their Clothes" shows how the financial, lyrical, stylistic, and market infrastructure created by hiphop's success (evidence of the new ways and places capital circulates) opened 
doors for the creation and popularization of the gospel hip-hop hybrid, "holy hip-hop." Smith Pollard's chapter focuses almost exclusively on holy hip hop, the term she uses to discuss Christian rap music. She begins by outlining the controversy that often arises from the fact that, although its fans and practitioners see it as one of God's many ways to reach the "post-civil rights, postR\&B generation," many of holy hip-hop's opponents accuse the genre of being sacrilegious. However, Pollard argues, a closer examination of the testimonies and lyrics of many artists reveals that, even though their musical evangelism is generation-specific in its "packaging," the general goal of the music is the same as that of traditional gospel music: to bring Christianity to the masses. Furthermore, Pollard argues, in several of its performative elements and lyrics, holy hip-hop illustrates many cultural traditions of the African diaspora in general and of the African American church and its traditional gospel music in particular. Such traits include call-and-response, vocal intonation, testimony, and evangelical zeal.

The second section centers on dance, foregrounding the ways that dance inspires, reflects, and enacts the productive dynamics of cultural circulation in this era of globalization. Significantly, the essays here focus variously on the specifics of the body gestures born of cross-cultural and intercultural contact and on the politically and epistemologically subversive possibilities and implications of dance as an art form.

Linking Afro-Atlantic religion with the corporeal intellect inherent in sacred dance, Yvonne Daniel's "Rhythmic Remembrances" explicates how African-originated valuations of rhythm and ritual have persisted in the African diaspora, particularly in the "danced, sung, and drummed knowledge" that survived New World slavery and is now retained in the religious practices of Haitian Vodou, Cuban Yoruba, and Brazilian Candomblé. Daniel points out that although the general objectives of such rituals are to gain personal strength, achieve spiritual balance, worship divinities, and maintain the solidarity of the ritual community, some of their effects include the awareness of the "stored knowledge" within the human body and the discovery of the vast knowledge that still exists within the rituals of African diasporic religious performance. For example, some traditionally African religious chants contain rich information about the religious and therapeutic uses of herbs and plants, drum patterns exhibit sophisticated mathematical complexities, and dance movements challenge and strengthen the body's physiological and psychological capacities.

The bridging of healing, education, and arts, and the affirmation of their 
constant interactions with politics and resistance are central to Millery Polynés chapter in this volume. He examines the development of danse folklorique Haïtienne (Haitian folkloric dance) by Jean Léon Destiné and Lavinia Williams, discussing the ways in which each dancer employed it to entertain and educate their audiences on Haitian culture, as well as to better train Haitian dancers in the 1940 and 1950s. Polyné concedes that although they were not completely successful in eliminating all of the stereotypes associated with vodou and its sacred dances, their "innovation and transmission" of the art form educated dancers and their audiences on Haitian and West African-based cultural heritages that helped attract tourists to the island and advance Haiti's project of economic and cultural development. Through "cultural ambassadors" like Destiné and Williams, popular dance became evidence of Haiti's cultural progress, even as government officials and upper-class Haitians feared that Haiti's modern image was being challenged by dancing's focus on the "primitive" elements of the Haiti's vodou religion. Indeed, by advancing vodou-inspired Haitian culture, both the dancers who performed and the officials who supported them were making a bold statement against a Eurocentric Haitian (and global) society that ignored and demeaned African diasporic peasant art forms. By doing so, individuals like Destiné and Williams used the "popularity and evolving representation" of Haitian folkloric arts as a means to address both the economic and sociocultural challenges to modern development in mid-twentiethcentury Haiti.

A similar quest for economic development, cultural modernity, and a history and a historicity located in the performances, rituals, and reenactment of remembrances has created an obsessive search for alternative forms to Western modernity, and this quest has had a great influence on the Brazilian development project. In her contribution, "Citizenship and Dance in Urban Brazil," Lucía M. Suárez utilizes the concept of anthropophagy in order to discuss modern Brazil's failed and ever-evolving attempts at "aesthetic and economic progress." By arguing that the modern Brazilian city is in a natural but perpetual state of ruin, she contends that perhaps the dancing body can represent that city, since it, too, is in constant movement. She goes on to argue that dance memory performed by Brazilian artists celebrates a rich African musical, cultural, and religious past but is also an act of rebellion that challenges the rigidity of the country's complex class, gender, and racial hierarchies. For illustration, she examines the Grupo Corpo, a Brazilian dance company that has performed over thirty original choreographies in the last four decades. She argues that the company's technical style integrates ballet, African, and modern dance, thus mirroring 
Brazil's complex sociocultural history, and that with its first major performance, Maria Maria, it became one of the first "highbrow" dance troupes to do so on an "elite" national and international stage. According to Suárez, such events are important because the violence committed against the poor and other marginalized groups in a virtually lawless police state has placed Brazilian democracy in grave danger. Citing the 2002 documentary Bus 174 as proof of the desperation of the underclass, Suárez argues that groups like Grupo Corpo and its offshoot Corpo Cidadão are crucial in modern-day Brazil-they serve as powerful examples of how art and community can work together to better the lives of those most negatively affected by mid-twentieth-century Latin America's failed modernizing projects and most heavily affected by today's neoliberal economics and globalization. Suárez concludes by declaring that modern dance has become far more than a "rebel movement" against classical European dance forms; it now serves as the body's illustration of Brazil's "multiple narratives of tradition and progress" and as a tool for sociocultural change.

The line of inquiry opened by Du Bois and the Negritude authors on the conversation between the African and the African American through dance, a "form of [corporeal] communication" (Glissant), is at once recalled, revised, and restaged in this volume by Susan Leigh Foster, who shows how two contemporary women choreographers- the Senegalese Germaine Acogny and the African American Diane McIntyre-are able, through a repertoire of corporeal techniques, to recover, (re)imagine, and rescript their African heritage in order to index a range of experiences, emotions, practices, and narratives of the Black Atlantic. By "choreographing" black bodies, they reenact and unveil the histories of joy, sorrow, worship, war, pain, and pleasure, but they also (re)draw the geographies and itineraries carved in black skins and cut deep into black flesh. Using Bourdieu's and Foucault's theories of the corporeal memory in the oppressed, as well as scholarship on Africanist dance aesthetics, Foster explores conceptual possibilities of "muscle memory," the body's capacity to store and then evoke personal, psychological, cultural, and historical memories by muscular movement. She proposes that dancing has the capacity not just to remember but to reconnect the body to a cultural heritage by using a set of actions to evoke past instances of bodily movement.

Undoubtedly, this line of queries identifies music and dance as both marker and (re)enactment of black radical difference and alterity. Senghor, for example, considers musical and dance notations and rhythms as the mediating devices interconnecting music, speech, and dance as specific modes of represen- 
tation recurring in specific strategies aimed at producing "another reason," emotional and affective, "the reason of the touch of the Negro-African" rather than the "reasoning eye of the European." This essentialism has a radical subversive function: to deconstruct the ethnological invention of African cultural manifestations-dance in particular-as primordial, primitive, and prelogical forms of communication and cultural expression and as the privileged sites for the understanding of "primitive cultures."

The third section offers rich contributions on contemporary expressive and performative genres, paying close attention to emergent or totally ignored musical, discursive, or dance forms and particularly to the ways in which they are used by their practitioners to address issues of race and identity. This volume's concern with the organizing features and categories of the literature on the cultural expressions of the Atlantic world is remarkably reflected in the fresh exploration of the historical and continuing circulation and exchange that has shaped the poetics and politics of that world. These essays remap the different routes of the musical and dance waves by examining the multiple sites as well as the bridges between the performances, rituals, commodities, and expressive art forms aimed at enjoyment and political claims. Through focused case studies, this volume-particularly the third section-assesses the economies of knowledge and singular black modernities, narratives, and modes that the artists and their work create, thereby intervening in the debates surrounding "world music" and dance histories. Rhythms of the Afro-Atlantic World distinguishes itself as a collection that focuses on the circulation of cultural forms across the Atlantic world, tracing the paths trod by a range of music and dance forms within, across, or beyond the plethora of locals that constitute the Atlantic world. The editors and contributors of this volume do so, however, without assuming that these paths have been either always in line with national, regional, or continental boundaries or always transnational, transgressive, and perfectly hybrid and syncretic.

It is precisely from such a perspective that Raquel Z. Rivera examines, in this volume, the aesthetics of Puerto Rican and Dominican New York-based musicians and dancers who embrace traditionally Haitian and Afrodiasporic culture in their art. By doing so, she argues, they challenge the "hegemonic notions of Latin American/Latino nationality/ethnicity/panethnicity" that, though it claims to promote cultural inclusiveness, often ignores Latin Americans' rich and undeniable African heritage. These musicians forcibly introduce and celebrate their African heritage through various performances of bomba, the musical genre that most scholars and practitioners consider to be the oldest 
known of Afro-Puerto Rican forms, one that contains numerous subgenres and whose musical traits can be found in Cuba, Trinidad, the Virgin Islands, the southern United States, and, most important, Haiti. Indeed, bomba's use of Kreyól lyrics and devotional hymns to Vodun gods and its infusion of other Afrodiasporic-identified genres like rumba and hip-hop have angered many members of older generations, who want to retain bomba as a national product of Puerto Rico, not a genre that links together the African heritages of Caribbean New Yorkers. Nevertheless, asserts Rivera, bomba dancers and musicians "refuse to let their blackness be steeped in the bleaching waters of Latino self-denial," and this refusal allows for intercultural creativity and solidarity that is impossible through most of the overtly Eurocentric concepts of Latinidad, using Haiti as a much-needed bridge linking together the Afrodiasporic populations of the Spanish-speaking Caribbean.

Following the intensification of the music and dance traffic across the Atlantic animated by the youth, Halifu Osumare, in her essay titled "Motherland Hip-Hop," discusses the social dynamics of African hip-hop, using two rap groups-Positive Black Soul of Senegal and Kalamashaka of Kenya-as examples of hip-hop artists who have appropriated hip-hop music and are using it in an effort to improve socioethnic conditions on the continent. Using her theory of connective marginality, Osumare argues that overlapping global social spheres of culture, class, historical oppression, and youth itself complicate the typical explanation of American popular cultural imperialism for the perceived wholesale adoption of rap culture by global youth. By looking at groups like Kalmashaka (K-shaka) and Positive Black Soul (PBS), one is able to see that a large part of Africa's hip-hop movement is actually quite different from its contemporary American counterpart. According to Osumare, African hip-hop's focus on social critique, black liberation, and specific political challenges in various African nations is a far cry from the "bling-bling booty music" currently popular in the United States. She contends that African hip-hop, though comprised of a range of subgenres (many of which promote as much materialism and hedonism as their American counterparts), often promotes a rise in consciousness that actually has much more in common with U.S. hip-hop's earlier forms and its current underground scene.

This collection seeks to reorient the discourse on traveling cultural forms around and between Atlantic enclaves by being attentive to the specifics of the forms - their specific geneses, the specific uses to which they are put by their creators and consumers, and the specific ways in which they travel or churn in place. In doing so, it connects the attentiveness to music and trans-, circum-, 
and inter-Atlantic movements evident in the work of Atlanticist literary and cultural studies scholars with the linked explications of form and culture present in the work of ethnomusicologists and with the great emphasis on the particular nature of particular movements and/or particular locales in the work of Atlanticist historians such as Franklin W. Knight, Julius S. Scott, and Richard Price. This methodological blending widens the intellectual conversation while also pushing the scholarly discourse within the individual fields. For example, after giving a brief introduction to the origins and aesthetics of calypso, soca (the child of calypso), and go-go music, Deirdre R. Gantt presents her argument within such parameters, insisting that, despite differences in location and sound, both genres share a common goal: offering underrepresented populations the power to "negotiate and express their African heritage" and to "revise, affirm, and project their collective cultural identities" through music. Additionally, Gantt argues that both soca and go-go also share three African musical traits: polymetric ensemble drumming, call-and-response techniques, and the use of allusive repetition that can span the works of various artists over a number of years. After discussing the nuances of each of these traits in each genre, Gantt makes illuminating observations about how soca and go-go music have positively affected Trinidad's tourist industry and the public image of Washington, DC.

Patricia van Leeuwaarde Moonsammy, in her essay titled "Warriors of the Word," discusses rapso, an indigenous form of Trinibagonian music that, although it is a variant of calypso, is often overlooked as a part of the earlier genre's musical legacy. She argues that, like calypso, rapso artists often use their lyrics to enter into dialogue with the cultural, social, and economic politics of identity in their native land. By tracing rapso's offshoot from calypso through the experimentation of artists like Lancelot "Kebu" Layne, Moonsammy recovers the genre's long history of political involvement in union activism, labor strikes, and grassroots community development. Nevertheless, despite such a long activist involvement with the "downpressed," rapso is often ignored by Trinibagonian music lovers in favor of other, more popular (and, at times, less socially conscious) genres of music, like dancehall and American hip-hop. Moonsammy laments that cultural biases and unscrupulous owners of radio stations and record labels encourage rapso's marginalization; however, she also expresses hope that burgeoning technological advancements and a growing global cultural awareness will soon save it from the threat of obscurity.

In Timba Brava, contributor Umi Vaughan argues that timba is more than just an Afro-Cuban genre of music-it is also a rich cultural site on which sev- 
eral of Cuba's most heated social debates intersect, including those on economic policy, identity formation, gender roles, and, most important, the island's long history of complicated race relations. He further asserts that although it was born in the face of challenges posed by a radically changing Cuban society during the "special period" of the 1990s, timba is also the culmination of a centuries-old love-hate relationship between Cuba and its AfroCuban population. In fact, Vaughan dissects timba into four main stylistic elements (structure, timbre and texture, content, and context) and then focuses on the ways in which each area illustrates diverse musical influences-some of them traditionally Cuban, but many more of them Afrodiasporic. Even more interesting, Vaughan establishes very firmly that timba is heir to a long tradition in which Afro-Cuban culture persisted in the face of very strong opposition nourished by an upper class that wanted to present Cuba as a monolithic white country to the outside world. This history makes the genre most appealing during a time in which black and mulatto Cubans must assert their identities inside the country's rapidly changing culture and social structure. Vaughan concludes by stating that timba continues to negotiate complex relationships with the nation's government and international markets, maneuvering power and opportunity from a marginalized position to one of agency and power.

This volume closes with "Salsa Memory," a collaborative production by scholar Juan Flores and musician René López that enacts on paper the meeting of rhythms embodied in the pioneering salsa bands that are the focus of the piece. As a bridge between two political and musical eras (the 1970 and the present), René López and his bands enable an in-depth comparative case study that illuminates the possibilities inherent in the contemporary globalization moment. In tracing the historical and present-day versions of López's band and the ways in which they parallel and carry within them signal moments in the history and present of the conflicted story of salsa, "Salsa Memory" "amounts to an exercise in musical and cultural memory." Delving into the details of the bands' music, the role of each player and instrument in particular songs, and the very specific musical and cultural histories that rhythm and dynamic invoke, the essay lays bare the mechanics of various sorts of memory making through the aesthetic expressions explored throughout this volume. In this particular essay, the voice of the practitioner whose production process is underpinned by the corporeal and aural connection to the historical and rhythmic dimensions of the beats blends with the voice of the critic/historian/fan who cannot resist the call of the rhythm.

These interventions illuminate music and dance forms that at once restage 
and revise aesthetic, corporeal, aural, cultural, and political conversations about Africa, Europe, and America that have been going on at least since the beginning of the Atlantic slave trade. Born of this era of globalization, though, these forms also embody the distinctive tools available to Afro-Atlantic communities in this moment, not the least of which is the global market.

\section{Notes}

1. V. Y. Mudimbe, The Invention of Africa (Bloomington: Indiana University Press, 1988).

2. M. Wright, Becoming Black (Durham: Duke University Press, 2004).

3. In an interview with Benetta Jules-Rosette, Paulin Joachim, one of the first West African cineasts and an active participant in the Negritude movement, insists on such a quest of inserting "African culture into the civilization of the white man. It was to affirm our presence, pure African presence, because the colonizers have always negated our culture, as if they could be a people without a culture ... We wanted to create an African renaissance in Paris, to signify to the European in which we were immersed that blacks had their own culture and could assert that culture and that presence in the white world" (Benetta Jules-Rosette, Black Paris: The African Writers' Landscape [Urbana: University of Illinois Press, 1998], 35).

4. Ned Sublette, Cuba and Its Music: From the First Drums to the Mambo (Chicago: Chicago Review Press, 2004), 57.

5. Ibid., 58 .

6. Moreau de St Méry cited in ibid.

7. He adds CDs, twelve-inch singles, $\mathrm{MP}_{3}$ s, and videos to the repertoire of black Atlantic sound channels mentioned in Peter Linebaugh's remark that "the ship remained perhaps the most important conduit of Pan African communication before the appearance of the long playing record" (as quoted in Paul Gilroy, The Black Atlantic: Modernity and Double Consciousness [Cambridge, MA: Harvard University Press, 1993], 13).

8. For example, Robert O’Meally, Brent Hayes Edwards, Farah Jasmine Griffin, eds., Uptown Conversation (New York: Columbia University Press, 2004).

9. Robert O'Meally, ed., The Jazz Cadence of American Culture (New York: Columbia University Press, 1988).

10. Frederick Douglass, Narrative of the Life, ed. William L. Andrews and William S. McFeely, Norton Critical Editions (New York: W. W. Norton, 1997).

11. W. E. B. Du Bois, The Souls of the Black Folk (1903; repr., New York: Library of America, 1986).

12. Alain LeRoy Locked, ed., The New Negro (1925; repr., New York: Maxwell Macmillian International, 1992), 201.

13. Houston A. Baker, Jr., Modernism and the Harlem Renaissance (Chicago: University of Chicago Press, 1987), 60.

14. Du Bois, Souls of the Black Folk, 214. 
15. Baker, Modernism and the Harlem Renaissance, 77.

16. Locke, New Negro, 119-227.

17. Amiri Baraka, Blues People: Negro Music in White America (New York: William Morrow, 1963).

18. Edouard Glissant, Caribbean Discourse: Selected Essays (Charlottesville: University of Virginia Press, 1989), 248.

19. Du Bois, Souls of the Black Folk, 12.

20. L. S. Senghor, "L'esprit de la civilisation ou les lois de la culture négro-africaine," special issue, Présence Africaine (1956): 60-61. The translation, by Abiola Irele (The African Experience in Literature and Ideology [Bloomington: Indiana University Press, 1990], 76), is from the slightly modified version by F. Castaldi (Choreographies of African Identities: Negritude, Dance, and the National Ballet of Senegal [Urbana: University of Illinois Press, 2006], 23) (emphasis added).

21. R. Judy, "Introduction: On W. E. B. Du Bois and Hyperbolic Thinking," boundary 2 23, no. 3 (Fall 200o): 33 .

22. Alexander G. Weheliye, Phonographies: Grooves in Sonic Afro-Modernity (Durham: Duke University Press, 2005), 54. 
PART ONE: RELIGION 



\title{
The Economic Vitamins of Cuba: Sacred and Other Dance Performance
}

\author{
YVONNE DANIEL
}

\section{INTRODUCTION}

Dance practices are targeted economic commodities within the societies that I study. Although I am not an economist, I have had to account for the economic use of dance performance throughout my circum-Caribbean investigations over the past three decades. Particularly, African-derived religious performance has been included in and successfully promoted as tourist entertainment.

In Haiti, for example, the religious rituals of Haitian Vodou have been promoted in urban hotels and other tourist venues almost every night since the U.S. occupation in the early 190os, and they continue today. In the states of Salvador and Rio de Janeiro of Brazil, spectacular ritual dancing from the Candomblé and Angola religions are offered as part of Brazil's African heritage, acquainting eager tourists with at least two cultural elements of Brazil. Tourists are shown dynamic, African-derived dance practices of the coastal north and south in order to capture the exciting and exoticized image of the "brown dancing body"; however, in fairness, tourist directors use dance performance to broaden outside understanding of Brazil's diverse cultural palate. In Cuba as well, religious dance performance is presented with other types of dance as "cultural artifact" beneath the umbrella of atheistic, secular ideology, or Cuban communism/socialism.

In these circum-Caribbean locales, worshipers from the African-derived religions are not particularly upset with the transport of religious dance performance to the secular setting. They are quite used to the inclusion of sacred per- 
formances among secular, popular dancing in tourist enterprises. They conclude that the economic domain of the state or island nation indirectly supports African-derived religions and their dances. In Cuba, the geographical focus of this essay, worshipers know fully of the government's interest in their religions and utilize the national "guardianship" of the orichas, ${ }^{1}$ the inclusion of African dance practice in tourist settings, as their own public display, spiritual offering, and economic opportunity. They shrewdly suggest that their religious practices are support for good citizenship. They know that sacred dance, as well as secular forms of dance performance, gives small but continuous contributions to the economic health of the nation, as well as to their family congregations.

In this essay, I liken the linkage of dance performance and the economic situation of the Cuban nation to the role that vitamins play in the human body. Accordingly, I reexamine my Cuban dance data from the tourist setting, particularly sacred performance, and test my original findings from between 1985 and 1990. Early findings indicated that dance serves as "economic vitamins" to Cuba's ailing economy and as "aesthetic vitamins" and "spiritual vitamins" for hard-pressed international dance and music students.

\section{VITAMINS AND DANCE PERFORMANCE}

Vitamins are small amounts of complex organic substances that act as support elements and nutritional supplements for the healthy human body. As a minuscule economic product relative to other commodities, dance has emerged as a curious but supportive element for the health and well-being of Cuba's economy. Tourism is the most viable economic enterprise that the majority of Caribbean islands have at their disposal. As economic vitamins from the Cuban aesthetic system, dance performance has given vitamin-like nourishment to the Cuban economy, to Cubans, and to tourists alike. Cuba's difficult economic situation affords an example of how this happens-that is, how aesthetics and economic concerns interact.

Cuba's economic strategy has focused on cultural, ecological, and historical tourism, but since the 1990s, it has had to contend with the return of commercial, entertainment-focused tourism. Cuba has concentrated on the personnel and accoutrement of dance and extravaganza styles, and interestingly, this has included sacred dance. Yet economists and other observers of Cuba have generally neglected the effects of dance performance in terms of its contributions to Cuba's economy. ${ }^{2}$ The Cuban tourist industry has had to manage serious "rough spots" in its development, and dance performance has provided a 
buffering balm. In comparison with world tourist destinations, the Cuban tourist industry has had to confront limited goods, low levels of service, and aging or waning facilities. With the inclusion of a commodity that is literally "in motion" ${ }^{\text {"3 }}$ and formidably within Cuba's human resources, Cuba's competitive position and exchange potential have been augmented. My anthropological observations of dance in Cuba since 1985 have shown that dance performance has given "nourishment" to conventional economic and tourism development.

\section{A VIEW OF CUBAN ECONOMICS IN RELATION TO TOURISM}

Cuban tourism has been inexpensive for tourists relative to other Caribbean destinations, and Cuba has tapped a rather large European, Canadian, and Latin American market. ${ }^{4}$ Cuba's beaches, particularly Varadero in the northwest and Bacardi in the southeast, supply major percentages of tourist income. ${ }^{5}$ Joint ventures between Cuba and Mexico, Canada, Spain, and Japan, among other countries, have improved the Civil Aeronautics Institute, the hotel industry, and auxiliary service organizations, including hotel, road, and airport construction, as well as development of tourist management training. ${ }^{6}$ In fact, Cuban tourism grew from the 1970 s to the 1990s. By 1991 reports, tourism had equaled its formidable numbers in the Batista regime of the 1950s, when Cuba was the "backyard" of the United States and the "playground" of Europe and Latin America. ${ }^{7}$

Between 2000 and 2006, estimates for visitors to Cuba were projected from 160,000 to 200,000 visitors per year. ${ }^{8}$ Professor William LeoGrande, a specialist in international studies and Cuba, suggests that about thirty thousand of these were legal entries with U.S. licenses while twenty to fifty thousand were illegal U.S. entries through Canada, Mexico, and Caribbean nations. These estimates show that even with renewed and even more rigid restrictions from George W. Bush's administration (e.g., on cultural exchange in 2003 and education exchange in 2004), Cuban tourism has not been gravely affected by the ban on travel for U.S. citizens. ${ }^{9}$ Additionally, Professor Wayne Smith, former chief of the U.S. Interests Section and present senior fellow at the Center for International Policy, has stated that "while the new restrictions on the travel of Americans and Cuban-Americans to the island have of course reduced revenues from that source, overall revenues from tourism have not fallen, since Canadians, Europeans, and Latin Americans have continued to travel in even greater numbers." ${ }^{10}$

Heavy student travel from the United States to Cuba has diminished; in fact, only one of over thirty study abroad programs for U.S./Cuba exchange 
was in operation as of 2006. ${ }^{11}$ Again however, there does not seem to be a diminished interest in Cuba. "Cuban tourism has been thriving without us . . . The number of visitors has grown ten-fold since 1985, topping two million this year, and the revenue from tourism has grown twenty-fold," continues Professor LeoGrande. ${ }^{12}$ Indeed, revenue from tourism has seeded the tremendous growth in restoration and renovation projects throughout Cuba. Within these projects, dance has been incorporated into pivotal tourist shows and routine nightly socializing.

Tourists—called "special visitors" or "guests" in Cuba-have always found dance interspersed within eco-, historic, and cultural tourism. ${ }^{13}$ The Castro government has utilized its natural resources in ecotourism development, for example, in the lush Sierra Madre mountain range of the east, in the fishing industry along the north-central and eastern coasts, in the contrasting desertlike central region of Camagüey, and in the "country" ambiance of Pinar del Rio and Isla de la Joventud in the west. ${ }^{14}$ Additionally, the government has poured some of its profits into the restoration of historic structures, as well as whole districts of its historic capitals in Havana and Santiago de Cuba. By 200o, plans to restore architectural treasures from the Cuban colonial period (from the 1500 forward) were in full swing. Regardless of the reasons why tourists travel to Cuba, whether for urban conferences, symposia, and festivals or for mountain, beach, or country treks, they expect dance and music.

Cuba is struggling to maintain its socialist principles in a capitalistic world order. ${ }^{15}$ The remaining global superpower is determined to neglect, isolate, and thereby suffocate Cuba's political structure. Simultaneously, Cuba is defiant in its sovereignty, to the point of causing severe health and economic crises for its population. It has turned to and relied on tourist enterprises that reduce its financial dilemmas and theoretically give relief to the Cuban population. In recent years, these efforts have also placed some of postrevolutionary Cuba's goals in jeopardy. Nevertheless, the Cuban government has organized and regularly promotes dance for the indirect economic benefits it brings. Like vitamins, Cuban dance provides small but consistent stimuli to Cuba's conventional economic development.

\section{DANCE IN THE CUBAN TOURIST SETTING}

Since 1979, dance performance has been prominently identified as a marketable attraction within the Cuban Ministry of Culture. ${ }^{16}$ The ministry has worked with the tourist bureaus of Cuba (CubaTur, HavanaTur, and InTur), as well as 
the tourist bureaus of Canada, Mexico, Jamaica, and the Bahamas and Marazul Tours ${ }^{17}$ in the United States, among other international tourist bureaus, to supply performances mainly but also dance workshops for a steady stream of tourist groups. Perhaps because there is little world interest in two of the three commodities that are in abundance inside Cuba—sugar, rum, and tobaccothe Castro government has developed its human resources as its "cultural capital," in order to maximize limited economic opportunities and to accumulate foreign exchange. ${ }^{18}$ It has used what has existed in abundance continuously on Cuban soil; it has publicly presented what is carried inside the Cuban body and in the Cuban air with few encumbrances: Cuban dance. Cuba has displayed its dance in public, cultural, and historical frameworks within casas de cultura (district culture houses), hotel lobbies and nightclubs, theaters, patios, and poolside entertainment bars. ${ }^{19}$

Historically, tourists came to know about Cuban dance as its forms spread internationally via the film and recording industries and the international arts market during the $1930 .^{20}$ Later, from the 1970 s forward, Cuban dance was used like the Cuban education and medical systems were used, as cultural capital that provided domestic economic advantage but also international publicity (e.g., "health tourism" and "biotechnological tourism"). ${ }^{21}$ The latest example of Cuba's musical prowess at the international level occurred during the U.S. Grammy Awards in 2000, with the nomination of Buena Vista Social Club (Ry Cooder, producer), by a renowned group of soneros, for Best Latin Tropical Music Album. The album was inspired by the award-winning film in 1999 by the same name (Wim Wenders and Ry Cooder, producers/directors).

Due to the political circumstances of the 1980s and 1990s, dance workshops and music festivals developed within Cuba more than international touring of Cuban musical groups or award-winning dance choreographies. Festivals and workshops registered significantly among international visitors, and gradually a domestic awareness of the economic value of these universal practicesdance and music - took hold. The small but enduring consequences of dance performance were realized in the danced journey from Cuban streets to the national and international stage, as well as from small family "houses" and neighborhood religious "temples" to professional and community theaters. ${ }^{22}$

Beyond the magnificent beaches and splendid nightclubs that dominate Cuba's tourist market, all types of dance and music performances gained prominence as desirable products in the tourist industry, but few were as successful as sacred dances. Several types of sacred dance are usually presented: Yoruba oricha dances, Kongo-Angola Palo dances, Abakuá secret society 
masked dances, and Arará or Fon-based dances. Most often, the sacred dance traditions are woven into a secular array of dances called Sábado o Domingo de la rumba (Saturday or Sunday rumba). Although Cuban rumba is the most emphasized dance, tourist versions of sacred performance are prominently featured also, as a series of dynamic solos or as stimulating ensemble works that depict specific African traditions and divinities. ${ }^{23}$

Dance performance generally and sacred dance in particular have activated a resourceful tourism and economic strategy for the Cuban nation. Despite the discomfort of small, tightly packed chartered planes and the extra expense of traveling to manageable entry points for Cuba, and despite the tedious bureaucracy, sometimes inadequate services, and the grim difficulties that are observed daily, Cuba has reaped the benefits of dance performance and has profited in terms of a healthier economic base. It would be advantageous to have data on the relationship between dance performance and tourist enterprises from economists working on Cuba; however, from the dance and anthropology perspectives, Cuba, like nations everywhere and especially in the Caribbean, is utilizing local dance and music to augment, regulate, stabilize, or at the very least influence the tourist setting and tourist enterprises. ${ }^{24}$

\section{TOURIST VIEWS}

Special visitors, guests, or tourists in Cuba have popular dance on their minds when they first arrive. They cannot help but be bombarded with dancer images and musical sounds that entice them to travel and encourage them to move rhythmically. Dance and music are the lures for eating, drinking, gambling, and socializing profusely-for a price. Tourists are attracted to and often mesmerized by "the tourist show," which is eventually used to justify the extravaganza stylization of sacred dance traditions within patio theater, cabaret, and hotel programming. There is no question that Cuban dance is riveting, and many tourists in Cuba take part in festive dance and music-making all day and all night..$^{25}$

Travel to Cuba is not simply for pleasure, relaxation, or leisure dancing, however. The Cuban tourist experience resembles the liminal world of ritual. ${ }^{26}$ It separates the tourist from the normal, everyday patterns to which she/he has become accustomed and immerses him/her in the fullness of an extraordinary experience, whether the framing is diplomatic, scientific, or aesthetic (i.e., whether the tourists have come as part of diplomatic congresses and meetings; for scientific conferences; or for film, music, or visual arts festivals). Visitors 
leave worlds that are comparatively affluent and, consequently, once in Cuba, they limit their diets (due to what foods are available), augment their exercise (due to the transportation limitations of a "third world environment"), prioritize their foci, and return to their foreign destinations, usually rejuvenated.

Like many Caribbean nations, Cuba has invested in tourism as one of its most viable commodities. In the light of severe sugar and other losses in the "special periods" that have marked the Cuban economy for the past fifteen years, the Cuban government has apparently risked the drain of energy resources in order to secure a booming tourism industry and accommodate tourist facilities, interests, and necessities. First by word of mouth, then in Caribbean travel magazines, and later on the Internet, Cuba has promoted its uniqueness, including its incredulous and diverse beauty, endearing hospitality, and relatively safe environment.

In the past, even if Cuba's tourists intruded on scarce resources (housing, water, telephone services, electricity, gas, etc.), they simultaneously advertised Cuba as a unique tourist destination. On their return home, tourists were able to counter travel warnings about Cuba by referring to Cuba's enviable tourist position and pronounced distinctiveness. Cuba does not have the huge numbers of homeless people, street crime, and drugs that the rest of the world sees on a daily basis in other tourist sites.

Between 1959 and 1990, brigada recruits (volunteer, politically motivated international workers), scientists, artists, economists, and so on from the United States, Canada, Switzerland, Sweden, Japan, France, Finland, and parts of Latin America fathomed the arduous journey through bureaucratic papers to reach Cuba for one or two weeks. These curious travelers witnessed the warm and cordial realities of daily existence in a small island nation, and travel to Cuba grew. Then, commercial sex tourism resurfaced in the mid-199os and provided its guaranteed source of foreign currency reserves. ${ }^{27}$ "Sun, sand, and sex" became the apparent motivation for travel to over two hundred beaches throughout the island.

European, Asian, and American men from across the Americas, as well as U.S. American and European women, connected with casual and sometimes more permanent personal relationships. Dance for these tourists was (and continues to be) a means to survey human merchandise, and the popular nightclub scene became the market space. Dancing in these circumstances was the prelude or overture movement for mostly female performers; it quickly led to the beach, the restaurant, or the hotel room.

Despite its counterrevolutionary essence, "sun, sand, and sex" tourism has 
grown since the late 1990s. Prostitution and the sex trade have reappeared since their virtual disappearance with the success of the Cuban Revolution in 1959. It is the only consequence of the tourist setting that has changed significantly over time in terms of its relationship to dance (cf. charts 1-3). Review of tourism and dance from 1985 to 1990 did not show noticeable evidence of sex tourism; however, by 1995, that trade was clearly visible. The severe penalties for those caught in prostitution or the sex trade (three years of incarceration for a first offense and twenty-one years for a second offense) prove that it had become a threat to the political status quo. Still, the sex trade permeated most tourist environments. ${ }^{28}$ Unfortunately, dance was instrumental in that trade, although sacred dance was not generally involved.

Additionally, intense humanitarian and philanthropic values have attracted other tourists to Cuba. Many tourists come to see for themselves the commitment of the Cuban people in dealing with and overriding their politico-economic dilemmas. Tourists admire the endurance and flexibility of the Cuban people, and often they are moved empathetically to identify with and assist one or more Cuban families or Cuban communities in their struggles. In addition to providing financial benefits, these tourists often take their new extended families to Tropicana and other nightclubs or hotels with shows, as well as relax with them in household environments with evening dancing and music-making. Some visitors become part of religious families and spend time dancing for the orichas. The intense aesthetic attraction to Cuba's dance performance is contagious; it contains an intrinsic sense of well-being that cannot be overlooked or underestimated, whether at house parties, Tropicana, or religious rituals.

Dance performance assists both tourists and Cubans-sometimes in incremental ways and sometimes with secured, periodic economic improvements. Tourists facilitate Cuban dance in its function as aesthetic and/or spiritual vitamins for themselves and as economic vitamins for their Cuban friends, their extended families, and, ultimately, the Cuban nation.

\section{INTERNATIONAL STUDENT VIEWS}

The term international students here refers to those international dancers and musicians who have been intrigued by the more qualitative aspects of the Cuban scene, who are mesmerized by Cuban dance and music performance, and who generally travel to Cuba to study performance practices and techniques. While international students are still special visitors, guests, or tourists 
to the Cuban government, they are also a subdivision of tourists. They are most often attracted to Cuba by the intense aesthetic appeal of its music and dance and by Cuba's tremendous influence on the dance and music history of the Americas. ${ }^{29}$ Consequently, international students, unlike more typical tourists, have given themselves in cyclical rites to Cuba's rhythms for aesthetic as well as spiritual nourishment.

The proliferation of instructional workshops and dance and music festivals created the category of international students and drew dance students to Cuba in growing numbers throughout the mid-1980s and the 1990s. International students provided needed foreign currencies to Cuban dance organizations and, in return, received lessons and concerts, which stimulated the development of related dance industries. Students paid for taping of instruction and performances; they bought particular souvenirs-for example, rehearsal dance skirts and scarves, drums, chekeres (gourds), CDs, DVDs, ritual beads, and religious books-as well as regular tourist items like T-shirts, rum, cigars, Caribbean shell items, traditional dolls, and so on. They generally returned home contented, and through them, Cuba's small manufacturing enterprises and artistic organizations profited.

As other researchers have noted, tourism opens the door to a betwixt and between world that permits artists and lovers of expressive culture to indulge in near-ecstatic experiences. ${ }^{30}$ Perhaps even more than for general tourists, Cuban tourism offers the magical world of liminality to international dance students. The intensity in the learning of music and dance texts, the professional intimacy with Cuban maestros, and the immediacy of context in the Cuban environment produces an "out-of-this-world," profound impression on international students. They gain knowledge of new forms, sustain close friendships with revered artists, and usually arrive at a deeper understanding of the Cuban aesthetic than they have had before.

Dancers and musicians are consequently transformed by their Cuban experience. Some join Cuban dance companies in other countries on their return, some commit to research of particular Cuban dance traditions, and others have been known to start Cuban dance ensembles of their own. Most important, many prepare to ritually repeat the tourist experience as a periodic artistic and spiritual "vitamin supplement" to their lives. As anthropologist Nelson Graburn explains, tourist experiences are "profane spirit quests," and international students often repeat their Cuban dance search as the required repetition from a spiritual domain that they inevitably access. ${ }^{31}$

The dire economic circumstances in Cuba, however, as well as the strained 
economic situation of many international students, often make the exchange of foreign currency and dance performance an "exchange of sacrifices." ${ }^{32}$ European and U.S. American students struggle to eat and to study their art with little or no help from national, state, or local community funding. Additionally, they receive little financial support from family structure. Most U.S. parents, for example, would prefer to support students in scientific, computer, or business interests rather than in the arduous struggle of their dance or music passions. Consequently, many international students from the United States, Europe, and Latin America are sacrificing when they travel to Cuba for dance or music study.

Likewise, although not always recognized publicly, Cuban dance organizations are sacrificing Cuba's scarce resources to house, feed, transport, and entertain international students in training workshops and festivals. Cuban dancers and musicians sacrifice professional time away from performing, creating, and maintaining their artistic skills for exceedingly small teaching bonuses to their regulated salaries and for "tips" that they receive from international students. They acquire huge personal expenditures (additional transportation costs and expense for food away from home), which are associated with teaching groups of international students. Their physical expenditures are also taxed beyond the regular walks and long bus rides to their workplaces, and their teaching of dance workshops is done in addition to their routine eight- to ten-hour workday or six-day-per-week work schedule. Their involvement is predicated on the potential access to needed (or wanted) items that international students have (cf. the sections on Cuban dancers and musicians in charts 1-3).

Therefore, the international exchange of Cuban dance is associated with economic sacrifices as well as economic profits. Over time, international students have become the nexus for economic growth among Cuban dancers, musicians, and arts organizations. In such circumstances, dance functions in small, supportive, and consistent ways-again, like vitamins that function in the human body.

\section{CUBAN RELIGIOUS COMMUNITY VIEWS}

As ritual performers learn to perform divinity in their ritual families-first as ensemble members and then as soloists-they guard and protect the spiritual interconnections between the material and spiritual worlds. Their religious practices and ritual dancing stimulate good citizenship in both the internal ritual community and the external secular world. ${ }^{33}$ As religious practitioners perform in the tourist setting, they become aware that the nation publicizes their 
religions to thousands of international tourists. Those performances, however, are designed to distance the "sacred" and minimize "spiritual orientation," among tourists as well as viewing Cubans. Ultimately, Cuban ritual performances in the tourist setting are part of a secularization process that is inherent or presumed in Cuban communism/socialism.

Secularization does not seem to be working (at least from the perspective of religious community members), and I am not aware of any research that has indicated a decline in sacred practices in Cuba (or in Haiti or Brazil for that matter). Some citizens who are more officially connected distance themselves from public affinity with African religions of Cuba because of the historical stigma they continue to retain, but despite the removal of sacred performance onto a secular tourist stage, the overwhelming consequence of sacred performance in Cuban tourist settings is increased acceptance and, potentially, increased understanding. Wherever sacred dance of Cuba is performed, it stimulates interest and sometimes fortifies belief.

Consequently over time, ritual community members are not dismayed by the secular environment of sacred dance. More often, they are readied for new contacts, eager apprentices, and the access to needed items, monetary gifts, and other presents that visitors are instructed to bring to the religious ceremonies, which often follow tourist performances. Religious community members take advantage of the economic exchanges that surface in both sacred and tourist settings, and they use tourist performances as supplemental activities that attract and provide possibilities for religious ceremonies, religious conversions, and economic improvements.

\section{SACRED DANCE IN THE SECULAR SETTING}

Sacred dance in Cuba initiates awe and propels fascination in both the sacred and secular settings. The consequences of performance in the tourist setting continue over time and include (1) crystallization of form, (2) cultural preservation, (3) dispersion to new sectors of the population, (4) intratraditional synthesis in new dance forms, and (5) secularization of content.

In each analytical review, sacred dance traditions were condensed or crystallized in the Cuban tourist setting, but crystallization did not render sacred dance ineffective. In fact, sacred performance is deceptively analogous to the miniaturized drums that are found for sale in tourist shops: visually representative, but presumed to be lacking in effectiveness. The difference between the effects of the drum artifact and dance performance is "experiential authentic- 
ity," that is, the profoundest of performing experiences. Experiential authenticity convinces both performers and tourists (or spectators) of the integrity, authenticity, or genuine nature of the performance. ${ }^{34}$ Even in its crystallized form, sacred performance in Cuba continues to be awe-inspiring, indelibly impressive, and potentially transformational.

Sacred dance in the tourist setting has also helped to preserve the four African-derived religions of Cuba. They have survived for four centuries and are the major African belief systems in the Americas today. Despite their endurance, worshiping practitioners have been persecuted in Cuba as religious counterrevolutionaries, particularly from 1959 to 1984. Yet the "sacred choreographies" are offered to tourists as Cuba's cultural history or African heritage and are thereby "folklorized" views of sacred rituals. From time to time, performances do stimulate research, as Cuban dance groups investigate traditional religions in order to portray the powerful choreographies and to choreograph intelligently, as well as creatively, for the tourist arena. ${ }^{35}$

Each review of sacred dance in the tourist setting has also documented the spread of sacred traditions globally. Dancers and drummers of differing ethnicities have studied the full range of Cuban rhythms as tourists and have transported sacred traditions internationally. Batá drumming, for example, which has historically been isolated in Cuban religious communities, has spread internationally as a musical style. Additionally, a change in the gender role of drummers has taken place. Originally drumming was a male tradition, but more recently, female percussionists, both inside and outside of Cuba, have become actively involved. They do not perform in ritual settings, but they have steadily increased among tourists to Cuba. ${ }^{36}$

Some intratraditional synthesis of sacred dance traditions has also appeared with each reevaluation. Batarumba is an innovative form of rumba that has evolved or reemerged in the tourist setting. It combines Kongo-Angola secular, Yoruba sacred, and Cuban secular drum rhythms with their corresponding dance movements; it mixes the sacred choreographies of the orichas, traditional rumba, and contemporary casino or salsa dancing. The result is a dynamic combination with rich diversity in both the music and dance portions of performance.

Timba, or "maroon music" is a more contemporary example that has emerged also. ${ }^{37}$ Here, the familiar ambiance of popular Cuban dance (son or casino/salsa) is heightened and nationally personalized within contemporary popular culture and global hip-hop audiences. Timba dance recalls the wild, unharnessed, and uncontrollable (read revolutionary, persistent, and resilient) 
characteristics of cimarron (runaway) existence in the enslavement era. Like the popular and more classic sones of generations past (e.g., Merceditas Valdez's Osain with Jose Maria Vitier's Ensemble, Celina González's ; Que Viva Changó!) or contemporary casinos/salsas (e.g., in Lázaro Ros's experiment with Síntesis), timba blends spiritual stances from African heritages within Cuba and traditional sociopolitical messages with postmodern, high-tech, and global stylization of lyrics, instrumentation, dance movements, and, most important, rhythms.

It is the secular ambiance of the tourist setting that has allowed both batarumba and timba to develop. It is also the tourist setting that has permitted the momentum of sacred performance to mesh with the popularity of social dance and gain domestic and international acceptance. The tourist setting has functioned as a strong vitamin for creative development of dance performance, a megavitamin.

In reexamining tourist dance performance of Cuba in 2008, the most consistent observation has been the use of sacred dance traditions. The overarching government attempt to minimize religion and marginalize spirituality seems to have been ineffective. As stated earlier, the Cuban tourist setting potentially compromises sacred dance by presenting it away from its sacred framing in orthodox ritual, but government secularization has not succeeded in destroying or inhibiting African religious practices. New combinations and different proportions of "the old" and "the religious" continuously surface. Even with the use of new technologies and contemporary perspectives inside the secular tourist environment, sacred dance traditions remain solid in Cuba and are not easily penetrated. Although innovation occurs and finds a comfortable residence in popular dance, sacred dance is resilient and apparently still strong in the tourist environment also.

Dance, often the product within tourist shows, is affected by its use as an economic vitamin; however, it is not as significantly changed as its performers and viewers are changed. Dance continues in all its varieties in the tourist setting and aids performers and tourists alike to enrich their lives, their bodies, and their opportunities. It also assists Cuba's precarious economic situation.

\section{CONCLUSION}

As charts 1-3 indicate, covering my observations since 1985, indicate, the Cuban government, tourists, international dance students, and the African religious communities of Cuba all share interests in dance performance within the 


\section{CHART 1. Effects of Tourist Dance Performance in Cuba, 1990}

\section{On Cuba}

1. Framing of international image: unique island-nation

2. Economic vitamins: increased foreign exchange; development of tourism, hotel, and related manufacturing industries

On Cubans (dancers, musicians, arts administrators)

1. Employment

2. Organizational development

3. Aesthetic nourishment: spontaneity, "jamming," creative opportunities

4. Access to professional items: tapes, recorders, batteries, foreign music, etc.

5. Access to nonprofessional items: rum, jeans, pullovers, cosmetics, etc.

\section{On Guests (tourists)}

1. Aesthetic nourishment: specialization, virtuosity

2. Cultural nourishment: knowledge of rarely viewed society and culture, research

3. Spiritual nourishment: liminal experience, indulgence in preferences

\section{On the Dance Product}

1. Form reduction or reshaping

2. Cultural preservation: protection of traditions, popularity, diffusion

3. Cultural conservation: aesthetic vitamins for vitality and aliveness, intratraditional synthesis, etc.

4. Secularization

tourist setting. For the Cuban nation, dance performance continues to be integral to historical and cultural tourism as well as ecotourism, and it is profitable as well. Since advertisements of tourist settings often feature the dancer and dance performance as symbols of carefree, sensual, leisure activity in order to entice international tourists, dance performance has played and will most likely continue to play a pivotal role in Cuban tourism (as well as in most Caribbean tourism). Tourist performance has increased opportunities for Cuba to augment foreign currency reserves, but since the mid-1990s, both benefits and deficits have been noted, particularly in connection with the sex trade.

For tourists, dance performance is "a must" in Cuba. It is an opening to unusual experiences, personal contacts, and sometimes economic enterprises. Tourists use Cuba as a retreat from work and stressful living; they plough into dance performance as aesthetic and, sometimes, spiritual vitamins that supple- 


\section{CHART 2. Benefits and Deficits of Tourist Dance in Cuba, 1995}

For Cuba

1. Framing of international image: unique island-nation with unique brand of tourism

2. Economic vitamins: increased foreign exchange; development of tourism, hotel, and related manufacturing industries

3. Potential increase of social problems: prostitution of women, men, and children; potential spread of venereal, AIDS, and HIV diseases; possible resurgence of machismo

4. Goals of revolution threatened with severe demand on human and natural resources

\section{For Cuban Dancers, Musicians, Arts Administrators}

1. Employment

2. Organizational development

3. Aesthetic nourishment: spontaneity, "jamming," creative opportunities

4. Access to professional items: tapes, recorders, batteries, foreign music, etc.

5. Access to nonprofessional items: tomato sauce, cooking oil, rum, jeans, pullovers, cosmetics, etc.

6. Increased entrepreneurial competition and individual opportunism

7. Potential loss of stewardship of cultural forms with both national and international appropriation

\section{For Guests and International Students of Dance}

1. Aesthetic nourishment: specialization, virtuosity

2. Cultural nourishment: knowledge of rarely viewed society and culture, research

3. Spiritual nourishment: liminal experience, indulgence in preferences

4. Consumer frustration, hunger, or greed leading to exploitation and/or disruption of cultural forms

\section{For the Dance Product}

1. Form reduction or reshaping

2. Cultural preservation: protection of traditions, popularity, diffusion

3. Cultural conservation: aesthetic vitamins for vitality and aliveness, encouragement of organic development of traditional forms

4. Radical change: intratraditional synthesis, interpenetration of innovation toward absolute change

5. Potential secularization of the "sacred" or secralization of the "touristic" 


\section{CHART 3. Effects of Sacred Dance in the Cuban Tourist Setting, 2006}

On Cuba

1. Additional, nonpolitical tourist attraction factor

2. Projection of religious openness for public, international image

3. Economic vitamins: adds to foreign currency reserves; adds to tourism, hotel, and related manufacturing development

4. Buffers the threat to revolutionary ideals: in the re-entrenchment of prostitution and the sex trade; potential spread of venereal, AIDS, and HIV diseases; women's liberation achievements

5. Augments sociability in ecotourism, cultural tourism, and historical tourism

On Cubans (dancers, musicians, arts administrators, and religious community members)

1. Employment

2. Opportunities for organizational development

3. Spiritual nourishment: gives knowledge of and acquaintanceship with African heritages in Cuba and thereby deepens religious affiliations; provides religious communities with connection to potential supporters of religious "houses"

4. Access to professional items: DVDs, tapes, recordings, batteries, "foreign" music, etc.

5. Access to nonprofessional items: rum, jeans, pullovers, cosmetics, deodorant, toothpaste, cooking oil, tomato sauce, etc.

6. Potential contact with or involvement in the sex trade

7. Potential contact with or involvement in the "black market" trade

On Tourists (guests and international dancers and musicians)

1. Spiritual nourishment: liminal experience, contact with knowledgeable mentors and spiritual workers

2. Aesthetic nourishment: specialization, virtuosity

3. Cultural nourishment: knowledge of "dancing religions"

4. Potential contact with or involvement in the sex trade

5. Potential contact with or involvement in the "black market" trade

On the Dance Product (sacred performance)

1. Crystallizes and condenses form

2. Conserves cultural traditions; encourages organic development of traditional forms

3. Opportunities for intratraditional synthesis; interpenetration of innovation toward change

4. Nominal potential for secularization 
ment their lives. They exchange their financial and personal resources for special recordings, sun, fun, a room for a few days, or an extended family experience. Some tourists have had opportunities to partner with enterprising Cubans and even create travel enterprises for international dancers and musicians. $^{38}$ Sacred performance remains a reliable attraction for tourists, offering spiritual support or simply heightened interest.

For international students, the extraordinary experience of Cuban tourism is enlarged over that of other types of tourists. Their proximity to celebrated Cuban dancers and musicians propels intense involvement that is more contagious than with other tourists, and the chances of their repeated visiting are increased. International students, however, often experience the difficult exchange between their limited resources as budding or struggling artists, and the equally limited resources of Cuban master dancers and musicians. International students usually return home committed to memories of Cuba through its dance traditions, and these are very often the sacred traditions.

For Cuban performers, dance in the tourist setting means reliable employment, pride, self-esteem, and professionalism. Their expertise is publicly acknowledged, and through their training and performance, they are alerted to Cuban history and Cuba's pivotal role as creator of many dances and major contributor to "American" dance. Their portrayals of dramatic spiritual entities are both challenging and rewarding, and as their expertise grows, they often deepen as spiritually committed performers.

For nonperforming Cubans, dance performance is entertainment and education. At the very least, the national public acknowledgement of Cuban dance provides education and activates or restores cultural pride in many Cubans. For Cuban religious practitioners, there is an ongoing or renewed connection to the ritual world with sacred dance in the tourist arena. Practitioners have hopes for the spread of sacred traditions across many tourist worlds. Performers, practitioners, and nonperforming Cubans look to the tourist setting for the possibilities of economic improvement.

In sum, dance constantly rejuvenates performers, international students, and tourists, and it has nourished postrevolutionary Cuba in the same way for almost fifty years. Dance performance is and will continue to be used strategically by the Cuban government, tourists, performers, and religious practitioners. Like vitamins, those complex organic substances, dance is a potent (albeit miniscule) nutrient that gives spiritual, aesthetic, and economic nourishment-sometimes to island nations, sometimes to tourist enterprises, and at other times to both tourists and Cubans. Like vitamins, dance performance op- 
erates critically in the regulation and functioning of Cuban tourism, and tourism strategies are absolutely necessary for Cuba's economic well-being.

\section{Notes}

I am grateful to Professors Nwankwo and Diouf and to the Atlantic Studies Initiative Conference Committee of the University of Michigan for the opportunity to publish further research on dance and tourism. I am indebted also to Smith College for facilitating research in Cuba over the years. I am equally grateful for writing time given through a Visiting Scholar Fellowship at Mills College's Women's Leadership Institute (1999-2000) and through a Rockefeller Foundation Fellowship at the Center for Black Music Research in Chicago and the Augustus Music Research Institute in St. Thomas (2005-6). Ultimately, my findings are based on almost annual fieldwork in Cuba from 1985 to 2000 and on later observations and study from outside of Cuba.

1. Oricha/orixa/ orisa refers either to an entire Yoruba-based religion or to the spiritual entities or divinities of those religions-namely, Cuban Yoruba or Santería, Brazilian Candomblé, and Nigerian or Beninoise Orisa, respectively. There are other spiritual divinities included in Cuban tourist performance, called nkisis from Kongo Angola-derived Palo, íremes from Carabalí-derived Abakuá, and vodunes from Fon-derived Arará religion. Here, I mention the orichas as the most popular and most frequently encountered spiritual entities within the Cuban tourist setting.

2. Levine, New Cuban Presence; Zimbalist, Cuba's Socialist Economy; Zimbalist, "Reforming Cuba’s Economic System"; Pérez-López, "Islands of Capitalism."

3. See Robert Farris Thompson's African Art in Motion, followed by his student Barbara Browning's Samba: Resistance in Motion.

4. Espino, "Tourism in Cuba," 155.

5. Economic Intelligence Unit, "Cuba," 19-31.

6. Fernandez, "Continuity and Change," 41-66; Espino, "Tourism in Cuba," 147-49, $152-55$.

7. Economic Intelligence Unit, “Cuba," 21.

8. LeoGrande, "Lift the Ban"; W. Smith, "New Cuba Commission Report."

9. LeoGrande, "Lift the Ban."

10. W. Smith, "New Cuba Commission Report."

11. LeoGrande, "Lift the Ban."

12. Ibid.

13. V. Smith, Hosts and Guests.

14. Medina and Santamarina, Turismo de naturaleza; Tamayo Torres, Pinar del Río.

15. Pérez-López, "Islands of Capitalism," ix-xviii.

16. Daniel, Rumba.

17. For almost thirty-five years, the only U.S. travel agency that was legally permitted to do business with Cuba was Marazul Tours.

18. Bourdieu, Outline, 177, 180; Distinction, 11-18.

19. Kaeppler, "Polynesian Dance"; Sweet, "Burlesquing 'the Other"”; Williams, "Traditional Dance Spaces"; and Gonzalez, "Mambo and the Maya."

20. Daniel, "Rumba Now and Then." 
21. Feinsilver, "Cuba as a 'World Medical Power'”; "Cuban Biotechnology."

22. Maquet, Introduction to Aesthetic Anthropology; Maquet, Aesthetic Experience; see also Graburn, "Anthropology of Tourism"; Cohen, "Authenticity and Commoditization"; Handler and Saxton, "Dissimulation"; Daniel, "Dance Performance."

23. Daniel, Rumba.

24. Ness, Body, Movement, and Culture, 177-98; Gonzalez, Jarocho's Soul; Gonzalez, "Mambo and the Maya"; Munsi, ed., Globalization and Dance; Espino, "Tourism in Cuba," $147-66$.

25. Cf. Silver, "Marketing Authenticity."

26. Van Gennep, Rites of Passage; Graburn, "Anthropology of Tourism," 9-33; Daniel, Rumba, 135-36.

27. Lombard, "Imagining and Performing"; Tchak, La prostitution á Cuba.

28. Daniel, field notes (1994, 1999-2001); Lombard, "Imagining and Performing."

29. Daniel, "Cuban Dance."

30. Van Gennep, Rites of Passage; Turner, Ritual Process; Graburn, “Tourism: The Sacred Journey"; Daniel, Rumba.

31. Graburn, “Tourism: The Sacred Journey," 21-36.

32. Georg Simmel quoted in Appadurai, "Introduction," 5.

33. Daniel, Dancing Wisdom. Cuban religious "houses" or temples operate in a mutual aid system or as a ritual family, but in Brazil, where the nation has not been as supportive of social services as Cuba has been, temple worshipers have taken more active roles in social citizenship. There, for example, huge religious families in large compounds often adopt orphans or rejected young boys, give assistance to HIV/AIDS patients, and care for homeless families, all of which are basically covered by the government in Cuba.

34. Handler and Saxton, "Dissimulation"; Daniel, "Dance Performance."

35. By 1998, Cuban dance/music artists were no longer denying or separating their religious affiliations from their cultural presentations or performances. Many artists, but also other Cubans, openly proclaimed official initiation in African-derived religions, according to my personal field observations in Havana and Matanzas.

36. See also Klein, Yorùbá Bàtá Goes Global.

37. Vaughan, "Timba brava."

38. Daniel, "Urban Festivals."

\section{Bibliography}

Appadurai, Arjun. "Introduction: Commodities and the Politics of Value." In The Social Life of Things, Commodities in Cultural Perspectives, edited by Arjun Appadurai, 3-63. Cambridge: Cambridge University Press, 1986.

Bourdieu, Pierre. Distinction. Cambridge: Harvard University Press, 1984.

Bourdieu, Pierre. Outline of a Theory of Practice. Cambridge: Cambridge University Press, 1977.

Browning, Barbara. Samba: Resistance in Motion. Bloomington: Indiana University Press, 1995.

Cohen, Erik. "Authenticity and Commoditization in Tourism." Annals of Tourism Research 15 (1988): 371-86. 
Daniel, Yvonne. "Cuban Dance: An Orchard of Creole Creativity." In Caribbean Dance: From Abakuá to Zouk, edited by Susanna Sloat, 32-93. Gainesville: University of Florida Press, 2002.

Daniel, Yvonne. "Dance Performance in Tourist Settings: Authenticity and Creativity." Annals of Tourism Research 23, no. 4 (1996): 780-97.

Daniel, Yvonne. Dancing Wisdom: Embodied Knowledge in Haitian Vodou, Cuban Yoruba, and Bahian Candomblé. Champaign: University of Illinois Press, 2005.

Daniel, Yvonne. Rumba: Dance and Social Change in Contemporary Cuba. Bloomington: Indiana University Press, 1995.

Daniel, Yvonne. "Rumba Now and Then: Quindembo." In The Social and Popular Dance Reader, edited by Julie Malnig. Champaign: University of Illinois Press. Forthcoming.

Daniel, Yvonne. “Urban Festivals: 'Dance for Sale.'” Paper presented at the American Anthropological Association (Festschrift for Professor William Shack), San Francisco, CA, November 22, 1996.

Economic Intelligence Unit (EIU). "Cuba." In Cuba, Dominican Republic, Haiti, and Puerto Rico: Country Reports, International Tourism Reports, 19-31. London, 1991.

Espino, Maria Dolores. “Tourism in Cuba: A Development Strategy for the 199os." In Cuba at a Crossroads: Politics and Economics after the Fourth Party Congress, edited by Jorge F. Pérez-López, 147-66. Gainesville: University Press of Florida, 1994.

Feinsilver, Julie. “Cuba as a 'World Medical Power.'” Latin American Research Review 24, no. 2 (1989): 1-34.

Feinsilver, Julie. "Cuban Biotechnology: A First World Approach to Development." In Cuba at a Crossroads: Politics and Economics after the Fourth Party Congress, edited by Jorge F. Pérez-López, 167-89. Gainesville: University Press of Florida, 1994.

Fernandez, Damien. "Continuity and Change in Cuba's International Relations in the 1990s." In Cuba at a Crossroads: Politics and Economics after the Fourth Party Congress, edited by Jorge F. Pérez-López, 41-66. Gainesville: University Press of Florida, 1994.

Gonzalez, Anita. Jarocho's Soul; Cultural Identity and Afro-Mexican Dance. Lanham, MD: University Press of America, 2004.

Gonzalez, Anita. "Mambo and the Maya." Dance Research Journal 35, no. 2-36, no. 1 $(2003-4): 131-45$.

Graburn, Nelson. "Anthropology of Tourism." Annals of Tourism Research 10, no. 1 (1984): 9-33.

Graburn, Nelson. “Tourism: The Sacred Journey." In Hosts and Guests: The Anthropology of Tourism, edited by Valene L. Smith, 21-36. Philadelphia: University of Pennsylvania Press, 1989.

Handler, Richard, and William Saxton. "Dissimulation: Reflexivity, Narration, and the Quest for Authenticity in 'Living History." Cultural Anthropology 3, no. 3 (1988): 242-60.

Kaeppler, Adrienne. "Polynesian Dance as 'Airplane Art.” Dance Research Journal 8 (1973): 71-85. 
Klein, Debra. Yorùbá Bàtá Goes Global: Artists, Culture Brokers, and Fans. Chicago: University of Chicago Press, 2007.

LeoGrande, William M. “Lift the Ban.” Cuban Affairs Quarterly Electronic Journal 1, no. 1 (2006): 1-16. http://www.cubanaffairsjournal.org.

Levine, Barry, ed. The New Cuban Presence in the Caribbean. Boulder: Westview Press, 1983.

Lombard, Stephanie. "Imagining and Performing the Intersections of Race and Sexuality: Global Information Flows and Sex Tourism in Cuba's Special Period.” PhD diss., University of California, San Diego, 2005.

Maquet, Jacques. Introduction to Aesthetic Anthropology. Reading, MA: Addison-Wesley Modular Program, 1971.

Maquet, Jacques. The Aesthetic Experience: An Anthropologist Looks at the Visual Arts. New Haven, CT: Yale University Press, 1986.

Medina, Norman, and Jorge Santamarina. Turismo de naturaleza en Cuba. Havana: Ediciones Unión, 2004.

Munsi, D. Urmimala Sarkar, ed. Globalization and Dance. New Delhi, India: Tulika Books.

Ness, Sally. Body, Movement, Culture: Kinesthetic and Visual Symbolism in a Philippine Community. Philadelphia: University of Pennsylvania Press, 1992.

Pérez-López, Jorge. "Islands of Capitalism in an Ocean of Socialism: Joint Ventures in Cuba's Development Strategy.” In Cuba at a Crossroads: Politics and Economics after the Fourth Party Congress, edited by Jorge F. Pérez-López, 190-219. Gainesville: University Press of Florida, 1994.

Pérez-López, Jorge, ed. Cuba at a Crossroads: Politics and Economics after the Fourth Party Congress. Gainesville: University Press of Florida, 1994.

Silver, Ira. "Marketing Authenticity in Third World Countries." Annals of Tourism Research 20 (1993): 302-18.

Smith, Valene L., ed. Hosts and Guests: The Anthropology of Tourism. Philadelphia: University of Pennsylvania Press, 1989.

Smith, Wayne. "New Cuba Commission Report: Formula for Continued Failure." La Alborada, July 10, 2006.

Sweet, Jill. "Burlesquing 'the Other' in Pueblo Performance." Annals of Tourism Research 16 (1989): 62-75.

Tamayo Torres, Guillermo. Pinar del Río: Tourismo verde. Havana: Editional José Martí, 1999.

Tchak, Sami. La prostitution á Cuba: Communisme ruses et débrouille. Paris: L'Harmat$\tan , 1999$.

Thompson, Robert Farris. African Art in Motion. Los Angeles: University of California Press, 1974.

Turner, Victor. Ritual Process: Structure and Anti-structure. Chicago: Aldine Publications, 1969.

Van Gennep, Arnold. Rites of Passage. 1909. Translated by Monika Vizedom and Gabrielle Cafee. Chicago: University of Chicago Press, 1960. 
Vaughan, Umi. “Timba brava: Maroon Music in Cuba.” PhD diss., University of Michigan, 2008.

Williams, Drid. "Traditional Dance Spaces: Concepts of Deixis and the Staging of Traditional Dance." International Journal of African Dance 1, no. 2 (1994): 8-20.

Zimbalist, Andrew. "Reforming Cuba's Economic System from Within." In Cuba at a Crossroads: Politics and Economics after the Fourth Party Congress, edited by Jorge F. Pérez-López, 220-38. Gainesville: University Press of Florida, 1994.

Zimbalist, Andrew, ed. Cuba's Socialist Economy: Towards the 199os. Boulder: Lynne Rienner Publishers, 1987. 


\title{
Performing Pentecostalism: Music, Identity, and the Interplay of Jamaican and African American Styles
}

\author{
MELVIN L. BUTLER
}

A growing trend in contemporary African American gospel has been the incorporation of West Indian influences in performances and commercial recordings. This trend is not particularly surprising, since for decades, music scholars have recognized the transnational ties between Jamaica and the United States. These ties have had a profound impact on the development of sacred and secular musical practice in both locales. Kenneth Bilby, for example, has noted that a significant amount of Jamaican popular music recorded in the 1970 s is imbued with a hymnlike quality that suggests the influence of African American church worship on Jamaican expressive culture. ${ }^{1}$ This essay discusses African American gospel artists and their music as a dynamically recontextualized, African diasporic phenomenon and focuses primarily on the reception and appropriation of island-influenced gospel recordings among Jamaican churchgoers at home and abroad. I seek not only to emphasize the transnational flows of gospel music from the United States but also to call attention to the ongoing negotiations of identity that occur as a result of these flows. In ways that are understood to be controversial, young Jamaican Pentecostals often strive to make this music by African American gospel artists their own, even as many religious leaders vehemently protest its perceived negative impact on Jamaican youth and the congregations to which they often belong.

Pentecostalism has been developing steadily in Jamaica since the 1920s, thriving along with belief systems such as Kumina, Revival (or Pocomania), and Rastafarianism. In a Caribbean nation where this brand of Christianity is, according to recent studies, now the professed faith of as much as a quarter of 
the population, ${ }^{2}$ believers see the music through which they articulate their faith as intimately connected to their religious and cultural identities. African American gospel music coming from the United States plays a complex and at times contradictory role in how Jamaican Pentecostals identify themselves in relation to religious and cultural outsiders. While in Jamaica in 2002 and 2003, I became increasingly fascinated with how Jamaican Pentecostals were appropriating music recorded by African American gospel artists. This music is transmitted to the island when U.S.-based gospel groups tour internationally; through Jamaicans traveling to and from the United States; and, most noticeably, by way of global cable networks, such as Black Entertainment Television, and through Jamaica's gospel radio station, Love 101 FM. Among Jamaican Pentecostals, television has traditionally been deemed an aspect of "worldly" living that is to be avoided as church members seek to lead a sanctified life centered primarily on asceticism and spiritual devotion. Although restrictions on television sets have loosened dramatically (since the turn of the twenty-first century), TVs are still viewed with suspicion by older Pentecostals, and it is only since the mid-1990s that radio has emerged as a significant medium for the transnational spread of North American gospel styles.

I therefore find it remarkable that many Jamaican Protestants and Pentecostals with whom I spoke are now drawn to African American gospel music styles and that they often characterize these styles as "black," though not necessarily "Jamaican." For churchgoers living in the urban areas of Spanish Town and Kingston, African American styles provide a means of expressing a "modern" Pentecostal aesthetic while counteridentifying against the "white" hymnody and "white-sounding" imported gospel music that some Jamaican congregations seem to prefer. "Black" styles are associated mostly with contemporary U.S. gospel artists influenced by rhythm and blues and hip-hop, but also with the traditional "clap-hand" choruses and the ska and dancehall rhythms characteristic of contemporary Jamaican gospel music. Whether they emanate from Jamaican or foreign soil, however, I contend that the use of gospel styles experienced as "black" significantly impacts the experiential framework of church "local" musical-social activity.

Gospel concerts in Jamaica and the Jamaican diaspora often feature a variety of styles, including traditional hymns and gospel reggae, as well as music recorded by well-known African American gospel singers such as Yolanda Adams, Kirk Franklin, Donnie McClurkin, and Fred Hammond. These events offer youth an opportunity to enjoy a Christian form of entertainment while 
socializing with churchgoers outside of their regular congregations. However, gospel concerts are viewed by many older Pentecostals as a recently acquired trend of which true believers should be wary. Thus, there prevails a certain skepticism with regard to any musical practice that is seen as a departure from established tradition.

A fondness for the Jamaica of yesteryear resonates with the lyrics of songs popular among older Pentecostals, many of whom converted during the 1950 s and 1960s. These Pentecostals often talk about the way things "used to be," back when Jamaica was "such a paradise" and when churchgoers took pleasure in singing classic hymns and Jamaican choruses, many of which are unfamiliar to younger generations. Through verbal testimonies and through hymns with titles such as "The Old Time Religion" and "Old Time Power," believers retell conversion experiences and express nostalgic sentiments brought on by the historical consciousness of past events, as well as through a "re-membering" process that blends lived experience with the biblical account of the day of Pentecost.

The opposition that some Jamaican preachers express toward African American cultural influence takes the form of a scathing critique of contemporary church practices, which, they contend, have strayed too far from the more "authentic" practices of yesteryear. One of the perceived dangers in moving away from traditional practices is that Jamaican Pentecostal identities will be compromised as so-called worldly influences begin to infiltrate congregations. The "modern" musical activities of many Jamaican churches are deemed inauthentic or "artificial" to the extent that they rely on emotionalism and entertainment rather than on the Holy Spirit for their affective impact. Church leaders often express a desire for a return to old times characterized less by "emotional" musical practices that "tickle the ear" and more by the transforming power of God's anointing. One preacher's sermon lamented the many changes that he felt have moved the church away from a genuine experience of the Holy Spirit. "What we need today," he asserted, "is not more music and emotional singing, but we need the old time anointing." He added, "This generation has to make so much music because they have to create an artificial joy! In the old times, the people ... didn't even have a lot of instruments. But when they sang 'What a Friend We Have in Jesus,' oh my! I don't need no organ to help me preach!"

The significant point here is that worldliness and "African Americanness" are conflated, at least implicitly, in the discourses of some Jamaican Pentecostals. Indeed, most of the "changes" mentioned by the preacher are experi- 
enced by older Jamaican churchgoers not only as more "modern" and "artificial" but also as evidence of African American influence on traditional Jamaican Pentecostal practices.

The preacher's reference to the hymn "What a Friend We Have in Jesus" provides evidence of a Jamaican preference for the meaningful lyrics of traditional hymns and "sober songs" over the "one-liners" and simpler choruses whose appeal derives more obviously from rhythmic or melodic elements. Although hymn singing is practiced by many African American Pentecostals, it is noticeably more prevalent among Jamaican churchgoers. The emphatic statement "I don't need no organ to help me preach!" refers to the organist's practice of interjecting percussive chordal attacks in between a preacher's words during a sermon. This occurs most often when a preacher switches to a singing or "intoned" style of sermonizing, which is more characteristic of African American preachers than Jamaican ones. The use of the organ to complement or "help" the preacher is not commonly found in Jamaica's Pentecostal churches, although I did occasionally notice it in urban areas such as Kingston and Montego Bay, where churches often attract preachers visiting from the United States.

For many Jamaican churchgoers, island-influenced gospel music is a means of expressing both religious authenticity and cultural distinctiveness. It can even become a way of musically asserting, "Not only am I a Pentecostal Christian, but I am a Jamaican Pentecostal Christian." This type of assertion is most striking among Jamaican Pentecostals living abroad in places such as New York and London, where religious, cultural, and long-distance national identities become a source of personal strength and a foundation for minority group consciousness.

\section{PERFORMING JAMAICANNESS: DONNIE MCCLURKIN'S CARIBBEAN GOSPEL MEDLEY}

To illustrate the way in which Jamaicans express cultural identities through gospel music, I would like to focus on a gospel performance by African American gospel singer Donnie McClurkin, using his recording Donnie McClurkin: Live in London and More (2000) to underscore the relation between religious and cultural identity. The recording, which is available in both audio and video formats, is McClurkin's second commercial release and was a hit among both African American and Jamaican churchgoers at home and abroad. After the CD was released, McClurkin made his first professional trip to Jamaica, performing 
a gospel concert at Church on the Rock, a Pentecostal church in Kingston, in October 2000. ${ }^{3}$ Since then, McClurkin's popularity in Jamaica has continued to grow. Throughout much of my field research in 2002, one particular track from the recording, "Caribbean Medley," was played almost daily on Love 101 FM.

McClurkin's performance takes place at London's Fairfield Hall before a predominantly African Caribbean crowd of gospel music enthusiasts. A woman emcee introduces him as "a native New Yorker whose second home is London" and expresses pride in the fact that McClurkin has chosen London as the locale in which to make his live recording. McClurkin and his group perform several selections before launching into a series of traditional Jamaican choruses. As this track on the CD begins, McClurkin introduces the medley and makes a verbal appeal to Jamaicans in the audience. ${ }^{4}$

Well, then, we gon' sing us some Jamaican songs. But if we sing 'em, you gotta get outta those seats. And you gotta dance like you're really from Jamaica, or your parents were from Jamaica, or parents' parents were from Jamaica! But I want you to be true to who you are!

McClurkin humorously exaggerates a Jamaican accent, repeating the word $\mathrm{Ja}$ maica several times and placing emphasis on the second syllable, which is drawn out and melodized to mimic the vocal inflection of a native patois speaker. He uses the idiomatic expression "parents' parents" in an attempt to draw on colloquialisms familiar to Jamaicans in the audience. McClurkin also calls on his listeners to be true to themselves, suggesting that participation in Jamaican-style gospel music and dance is a way for his listeners to assert and confirm their island identities. As McClurkin speaks, the band begins a reggaestyle accompaniment, with characteristic keyboard/guitar offbeats. The first piece of the medley is "I've Got My Mind Up." When the vocal melody begins, the bass guitar and bass drum complete the sonic approximation of classic 1970s reggae accompaniment, characterized by what is sometimes referred to as the "one drop" rhythm, marked by a stress on the second beat of each measure.

The second piece of the medley is "Goodbye, World." The keyboards, drums, and guitar continue the reggae-style accompaniment throughout this piece, as the rhythm of the bass guitar changes somewhat to support the new melody and chord progression. From "Goodbye, World," the group moves into "Born, Born, Born Again," which is one of the oldest and best-recognized choruses in the medley. In the middle section of this piece, McClurkin's voice becomes more forceful, taking on a rougher character as he imitates the 
"dub"-style delivery of a contemporary dancehall DJ. He cries, "Born of the water, Spirit an' de blood. T[h] ank God I'm born again!” which is sung four times against an accompanying backdrop that has shifted into the more percussive and syncopated rhythm also employed in contemporary dancehall performances.

Next, McClurkin's rhythm section returns to the classic reggae groove that underlies a repetition of the first medley piece, "I've Got My Mind Made Up." The recurrence of this chorus establishes it as the medley's unifying theme. The reggae groove is maintained as the band segues into "I Am Under the Rock," followed by the chorus "Jesus Name So Sweet." At this point, the bass line varies once more, switching to a simple arpeggio pattern that, like the previous "one drop" bass pattern, accents the second beat of each measure in typical reggae fashion.

After repeating the chorus' initial couplet, the rhythm section replays the syncopated dancehall rhythm while McClurkin delights the crowd by adding the short patois refrain "Every rock me rock upon Jesus, Jesus name so sweet!" This phrase does not translate easily into Standard English. However, Jamaican churchgoers explained to me that the repetition of the word rock and the idea of rocking "upon Jesus" suggest the idea of "movement" with Jesus-literally, through holy dancing, and metaphorically, through life's ups and downs. The chorus thus celebrates the "sweetness" of Jesus, who serves not only as a spiritual dancing partner during collective praise but also as a guide and comforter amid the "rocky" road of everyday life. This idea of movement is underscored by the chorus' additional patois refrains, which, although not performed by McClurkin, are sometimes sung in Jamaican "country churches."

Me slip and me slide and me rock upon Jesus.

Jesus name so sweet.

Me dilly and me dally and me rock upon Jesus.

Jesus name so sweet.

He concludes the medley by returning to "I've Got My Mind Made Up." However, before the final repetitions of this chorus, the instrumentalists suspend the classic reggae groove as McClurkin tells one of his coperformers, "Okay, Juanita, we sing it like this." He then shifts gears by slowing the tempo and inserting the chorus of the traditional gospel hymn "Oh, I Want to See Him.” During this hymn, the singer reverts to his celebrated R\&B-influenced contemporary vocal style, and the rhythm section backs him with a smooth, un- 
derstated accompaniment reminiscent of the sound of African American church music. Although McClurkin's prefatory remark, "We sing it like this," reveals to the audience his awareness of the cultural difference between himself and the audience, collective participation in the medley ultimately helps to foreground the common spiritual ground between them. By sandwiching this hymn within the medley's reggae choruses, McClurkin thus skillfully appropriates the contrast between Jamaican and African American styles of gospel expression.

Both the audio and video recordings of McClurkin's performance fade out on "Fire, Fall on Me," leaving the listener (or viewer) to imagine the continuing moments of celebratory praise induced by the "Caribbean Medley" and heightened by its final piece. McClurkin eventually introduces the next song with remarks that once again reveal his ability to manipulate cultural musical difference and effectively evoke "place" through musical sound.

Well, that's how you all do it in England and in Jamaica. Now I gotta take you to my home. I'm a-show you how we do it in Perfecting Church in Detroit, Michigan, where the pastor and founder is Marvin L. Winans!

McClurkin sings the last phrase, placing special emphasis on the church's pastor, a renowned contemporary African American gospel singer who later makes a guest appearance during the concert. After the short introduction, the band begins a bass-heavy funk groove, setting the stage for McClurkin's next piece, "Hail, King Jesus." Although McClurkin portrays this piece as emblematic of African American gospel expression, the song's musical style is viewed by more conservative African American Pentecostals as too worldly because of its perceived similarity to secular hip-hop genres. In fact, the musical styles of McClurkin and other African American gospel artists such as Kirk Franklin are often deemed wholly inappropriate for use in a Pentecostal church context. While these styles, sometimes referred to as "hip-hop gospel" or "holy hip-hop," may succeed in expressing an African American cultural identity, they fail to resonate with the religious identities of African American Pentecostals who fear the loss or contamination of the gospel tradition that they experience as vital to their contemporary practice.

I mention the interplay between religious and cultural identities among African Americans because it bears some resemblance to musical negotiations of identity among Jamaican Pentecostals. There is indeed a fascinating tension that arises between the way in which McClurkin employs musical style in his "Caribbean Medley" to signify cultural distinctiveness and the manner in 
which many Jamaican churchgoers use it to assert their Pentecostals identities. The Jamaican Pentecostals I interviewed express great pride in their "Jamaicanness." Moreover, they are adamant in their belief that their Pentecostal faith does not in any way make them "less Jamaican," even though their standard of holiness prohibits involvement in certain quintessential Jamaican musical genres. Although many Jamaican Pentecostals find the classic reggae style of McClurkin's medley entertaining in a concert setting or for radio listening, such a style is rarely performed during actual church worship. The same choruses are often sung, but the rhythmic accompaniment does not draw so obviously on a classic 1970 reggae sound, because it evokes images of the contemporary dancehall (where this style is still featured), Bob Marley, ganja smoking, and Rastafarianism.

In Jamaica's Pentecostal churches, traditional choruses are typically sung at a slightly slower tempo than that employed by McClurkin, albeit with a denser, more quickly moving underlying accompaniment. Pentecostal church musicians sometimes described their style to me as "old R\&B" or "ska," referring to the commercial popular music genre that developed on the island during the late 1950 and 1960s. At Mount Olivet and Riversdale Pentecostal Church, I was often impressed by the ska-like rhythmic accompaniment that characterizes most of the up-tempo singing.

In some cases, Pentecostals take issue with both the musical style and the use of Jamaican patois in a traditional chorus. Although preachers do occasionally switch into patois during sermons, hymns and choruses are nearly always sung in Standard English, which is viewed as the more respectable language within Jamaican society. The tendency to steer clear of Jamaican patois in sung expression may indicate a desire to avoid the social stigma historically attached to Pentecostal musical and bodily expressions. To illustrate this point further, we need only reexamine McClurkin's performance of "Jesus Name So Sweet." While most of the Jamaican Pentecostals to whom I spoke are familiar with the patois versions of the chorus, I rarely heard these lyrics during church services. Some pastors to whom I spoke expressed negative views of McClurkin's medley. For example, one referred to it as "a tacky Jamaican imitation." Another pastor took issue with the use of the phrase "Every rock me rock upon Jesus." "It doesn't mean anything," she complained in response to my question about the significance of the lyrics. "It's just some words they throw together!" Among conservative congregations, praise and worship moderators choose lyrics closer to Standard English, such as "Every time I talk about Jesus, Jesus name so sweet," after which they generally repeat the initial couplet. 
Near the conclusion of a service I attended at Mount Olivet, a group of teenagers began singing the chorus as some congregants stood at the altar seeking the infilling of the Holy Spirit. They began with a traditional rendition of the lyrics, but then, feeling uninhibited since the service was nearly over, they switched into patois versions of the chorus. Picking up on this shift and being familiar with McClurkin's recording, the instrumentalists began playing a dancehall reggae accompaniment. By this time, the Spirit infillings and refillings had already taken place, and most congregants were simply "rejoicing in the Lord," enjoying the celebratory aspects of Pentecostal musical praise. However, Pastor Orie, who had been trying for the past ten minutes or so to calm things down and stop the musicians from playing so he could dismiss service with prayer, gestured more urgently for the musicians to stop. "Okay, okay," he admonished, "we're getting carried away. Let's stick to the original. We want the Holy Ghost to always be in control." For Pastor Orie, as well as for many of the congregants, the musical style of the chorus had begun to get too worldly, crossing the boundary of appropriate church music.

\section{FUN IN THE SON: GOSPEL REGGAE, CONCERTS, AND POPULAR ENTERTAINMENT}

In February 2002, when I arrived on Jamaica's north coast to begin my fieldwork, I quickly gained a sense of the popularity of discourses concerning worldly and holy expressive behavior. In the local paper The Western Mirror, an article announcing the opening of a new adult nightclub called "Pleasure Dome" was placed adjacent to a poem entitled "Christianity versus Heathenism," which called for the espousal of a holier, more biblically based lifestyle among Jamaica's citizens. The journalistic juxtaposition of these two pieces indexed for me a moral dichotomy that is particularly discernible among the island's evangelical Christians and also present within the broader Jamaican society.

What reinforced my sense of the pervasiveness of this dichotomy between the church and the world was that Jamaica's tourist sectors were in the process of gearing up for the annual return of "Spring Breakers," many of whom would be college students from the United States. According to the Jamaica Gleaner, "the spring break season usually lasts for six weeks beginning in mid-February and attracts more than 50,000 college students annually." 5 Each year, this contingent of party-hungry foreigners faithfully descends on Jamaican resorts in and around Negril, Montego Bay, and Ocho Rios, where all-inclusive resorts, 
such as Sandals, Breezes, Club Ambiance, and Hedonism, cater to pleasureseeking young adults who crave fun and romance in an "exotic" locale. While local news reports highlighted the positive impact of tourism on the Jamaican economy, commentators expressed concerns felt by many Christians that the tourists were having a negative moral impact on Jamaican society. Another article in the Gleaner commented on the history of "lewd and excessive conduct" among visiting Spring Breakers who reportedly "stripped naked and used their tongues to clean whip cream $[s i c]$ from each other's bodies, while a large crowd cheered them on at a popular establishment in Montego Bay." Following a great deal of public complaint, the Jamaica Tourist Board and the Jamaica Hotel and Tourist Association issued a code of conduct discouraging sexually explicit acts among patrons and threatening to take severe actions against establishments that allowed them.

By March 2002, the Jamaica Tourist Board launched the country's first gospel spring festival, entitled "Fun in the Son." This three-week festival is extremely popular among young Jamaican Pentecostals. For foreign tourists, it offers a spiritually acceptable alternative to the rowdy party scene usually associated with Spring Break. "Fun in the Son" features Jamaican gospel artists such as Carlene Davis, Papa San, Stitchie, Grace Thrillers, Prodigal Son, and Robert and Genieve Bailey, as well as internationally known African American gospel performers such as Hezekiah Walker and Ron Kenoly. The festival provides a charismatic Christian dancehall space in which participants enjoy intense bodily participation-jumping and waving their arms to the sounds of gospel reggae. However, for some conservative Pentecostals, "Fun in the Son" overemphasizes the celebratory aspects of musical praise, "tickling the ears" of participants but failing to minister to their spiritual needs. It is wrong, they say, to engage in musical practices that so closely resemble those of the secular dancehall.

The music of secular dancehall artists such as Beenie Man, Bounty Killer, Lady Saw, and Buju Banton is considered too worldly for inclusion in either worship services or gospel concerts. However, since the mid-199os, a number of dancehall artists have converted to Christianity and begun recording gospel reggae songs featuring dancehall rhythms set to Christian lyrics. Gospel reggae artists such as Stitchie, Papa San, and Judy Mowatt have renewed their images and reestablished themselves as legitimate gospel artists. However, as Stolzoff notes, some critics question the sincerity of these conversions and suspect that they constitute nothing more than "a savvy marketing ploy to capture the untapped demand for dancehall music among Christian teenagers whose parents forbid them to listen to mainstream dancehall music."' Beenie Man's parodic 
rendition of "Gospel Time," conspicuously positioned as the first track on his $\mathrm{CD}$, no doubt represents both a marketing strategy and also a tongue-in-cheek response to dancehall artists who, unlike him, claim to have converted. ${ }^{8}$

Some Pentecostals to whom I spoke feel that certain musical styles, especially gospel reggae, are simply too worldly and therefore unacceptable irrespective of the contextual frame in which they are performed. Most Pentecostal pastors simply view gospel reggae as too stylistically distant from the hymns and choruses of the Pentecostal tradition to be used in the worship service. Cheryl, age thirty-two, serves as youth president in her organization. When I asked her about the styles she felt were appropriate in her church, located near Montego Bay, she replied,

Churches use different styles. For example, we use a lot of hymns for congregational singing ... It's my personal conviction. There are a lot of different styles churches use. It really depends on the focus you want to get. Reggae doesn't fit. It crosses the line for me.

Nonetheless, some Pentecostals deem gospel reggae appropriate within a festival or concert frame because it helps to attract young people and keep them in the church.

Most Jamaican Pentecostal pastors I have encountered teach against wearing makeup, jewelry, chemically straightened hair, and pants, establishing a set of prohibitions that have to do mostly with the comportment of women and girls. African Caribbean Pentecostal women differ from their African American counterparts in that the latter are much more likely to have straightened hair. Beyond that, there is a great deal of variation in the degree to which Pentecostal congregations adhere to specific rules concerning dress.

Among the saints, there is often considerable debate regarding the necessity of women abstaining from wearing pants, cosmetics, and jewelry. Although Pentecostal organizations sometimes exert influence over the way in which "holiness" is interpreted, it is typically the pastor who establishes the dress code for his or her congregation. Liberal-minded Pentecostals sometimes view the dress code as old-fashioned, too rigid, legalistic, and lacking a sound biblical basis. They argue that the code is overly dependent on "man-made" traditions and has become an unnecessary hindrance to the growth of Pentecostal churches. More conservative Pentecostals cite biblical mandates to "lift up a standard" (Isaiah 59:19, 62:10), stressing that while holiness is a matter of one's heart and not defined by dress, it should manifest itself through one's daily 
comportment, including outward appearance. Moreover, it is largely through the dress code that Pentecostals seek to distinguish themselves from the world of popular culture. Preachers often lament the fact that some saints are too eager to adopt fashionable practices, many of which stem from the United States. Thus, for many African Caribbean Pentecostals, upholding the standard involves preserving one's island identity and maintaining a critical distance from things negatively associated with the United States.

Some women have told me that they follow a stringent dress code purely out of obedience to their pastor. Others adopt the holiness standard wholeheartedly, particularly when they view immodest apparel as an unwanted reminder of their preconversion lifestyle. I have spoken to several Pentecostal women who adhere to the dress code because they feel a need to maintain the Pentecostal tradition handed down to them by their mothers and grandmothers. For these women, the standard of holiness is a sacrifice to God that they view as a sign of virtue and humility.

Given the fact that dress codes seem more prohibitive for women than for men, I asked Sister Wright whether she felt holiness standards make it harder for girls than boys to stay committed to the church. "No, it's the same," she insisted, "because boys have more peer pressure to get sexually involved." One of the reasons women strongly outnumber men in most Pentecostal churches may be that secular symbols of womanhood do not clash as harshly with Pentecostal holiness standards as do symbols of masculinity, which include alcoholic drinking, gambling, and sex outside of marriage. As Austin-Broos notes, "The moral signs indicative of being a clean vessel ... bear on why [Pentecostal] practitioners are more often women than men."

The disproportionately large number of males in church leadership roles no doubt reflects a long-standing gender bias in the broader society. However, as Austin-Broos suggests, the "assertion of a patriarchal status [through a leadership role] mitigates the inevitable denial of [other] signs of masculinity." ${ }^{10} \mathrm{I}$ would add that musical participation, particularly instrumental performance, is also a highly significant way through which Pentecostal men derive a sense of empowerment, a vehicle for self-expression, and a vital means of male bonding within an overwhelmingly female socioreligious context.

Sister Wright also spoke to me about the temptations of "worldly music," which she defined as "the reggae beat." She explained, "Sometimes you hear it [on a sound system] and you want to start moving [imitates secular dance moves]. And the children have it hard because the bus driver and the car driver could play music loud, and you can't ask them to turn it down!" When I asked 
Sister Wright about the kinds of gospel music she dislikes, she responded, "Calypso ... I don't like the calypso." By this, she referred to the genre known as "gospel reggae," which is enormously popular among young Pentecostals but often critiqued by elders because of its dancehall-influenced characteristics.

I had the opportunity to speak with Pastor Orie on several occasions during my three-month stay in Liliput. I was most struck by his commitment to the hard work of evangelism. "I never wanted to pastor," he admitted during one interview. "The most important thing is for people outside the church to get saved. We spend too much time sitting down inside the church." Noticing that there were no Pentecostal churches in Liliput, he originally came to the area with the hope simply to reach lost souls by teaching and preaching the Word of God. During one early-morning prayer meeting in 1998, when a lady was filled with the Holy Spirit, Pastor Orie became inspired to continue his work. The church land was donated by a man who lived nearby in a small, one-room house. "I feel God sent you here," the man had said, "so I'm gonna give you this land." Pastor Orie concluded that it was God's will for Mount Olivet to be established in its current locale. The biggest source of frustration for Pastor Orie is that he lacks the money to "go out" and preach like he wants. "There are a lot of areas," he insisted, "that need to hear the gospel." Therefore, he prays for the means to purchase a truck so that he can carry the Christian message to more people.

Although Mount Olivet is considered a mainstream church because of its nominal affiliation with the United Pentecostal Church (UPC), this U.S.-based organization does not extend to Pastor Orie any financial support. In fact, Mount Olivet was built using money mostly from his own pockets. "The saints here don't have much," he explained. He noted that the UPC churches in Jamaica are "not that well organized," particularly in terms of actively maintaining ties to sister churches in Jamaica and to the international headquarters in the United States. Consequently, the construction of new churches, such as Mount Olivet, is often undertaken without organizational oversight and sometimes lacks even local support from other churches on the island.

The Jamaican UPC churches meet twice a year, during February and August. Pastor Orie dreams of someday attending an international UPC convention in the United States and hopes that his ministry might receive a financial boost through organizational channels. Despite serious difficulties, Pastor Orie expressed his plans to continue expanding his work in Jamaica by building a new edifice in the upcoming months. "We have to go out and claim the land," he often preaches, referring to the Old Testament Israelites' mission to occupy 
enemy territories. ${ }^{11}$ "We have a lot of work that need to be done, just like in America."

\section{Notes}

1. Bilby, "Jamaica," 170.

2. Austin-Broos, Jamaica Genesis.

3. Jamaica Gleaner, October 23, 2000, http://www.jamaica-gleaner.com/gleaner/ 20001023/star/star1.html

4. The video version of the concert shows McClurkin first asking for applause from various African and African Caribbean ethnicities. He solicits responses from Barbadians, Trinidadians, and St. Lucians before finally asking the Jamaicans in the audience, whom he apparently knows to be in the majority, to show themselves by applauding. After their enthusiastic response, McClurkin proceeds to introduce the medley of "Jamaican songs."

5. Jamaica Gleaner, March 21, 2003.

6. Jamaica Gleaner, March 21, 2002.

7. Stolzoff, Wake the Town, 268 n. 4.

8. This kind of intertextual dialogue across the sacred-secular divide goes in both directions, as gospel reggae artists sometimes mention secular dancehall DJs on recordings and in live performances. I see the musically embedded conversations that take place among Jamaican singers as a kind of signifying practice common throughout the African diaspora. See Gates, Signifying Monkey.

9. Austin-Broos, Jamaica Genesis, 123.

10. Ibid.

11. Num. 13:26-30; Josh. 1:1-11.

\section{Bibliography}

Austin-Broos, Diane J. Jamaica Genesis: Religion and the Politics of Moral Orders. Chicago: University of Chicago Press, 1997.

Bilby, Kenneth. "Jamaica." In Caribbean Currents: Caribbean Music from Rumba to Reggae, edited by Peter Manuel. Philadelphia: Temple University Press, 1995.

Gates, Henry Louis, Jr. The Signifying Monkey: A Theory of Afro-American Literary Criticism. New York: Oxford University Press, 1988.

Stolzoff, Norman C. Wake the Town and Tell the People: Dancehall Culture in Jamaica. Durham: Duke University Press, 2000. 


\section{"The Women Have on All Their Clothes": Reading the Texts of Holy Hip-Hop}

\section{DEBORAH SMITH POLLARD}

Hip-hop, a billion-dollar global phenomenon comprised of graffiti art, turntable artistry, break dancing, and rap, has evoked some of the most complex and incendiary public discourse of the last thirty years. With music and cultural critics citing rap music's role in educating youth and in showcasing the "pro-woman" lyrical power of some female emcees, on one hand, and the media focusing on the violence, misogyny, and materialism, on the other, it would appear that the discussion could not possibly become more layered. ${ }^{1}$ However, the inclusion of religious themes has added another, often more controversial element to the discussion.

While references to the tenets of the Nation of Islam and the Five Percent Nation, Rastafarianism, and Christianity can be found within some of the lyrics of global rap music, the goal of this chapter is to focus exclusively on Christian rap/holy hip-hop. ${ }^{2}$ The controversy arises from the fact that its fans and practitioners view the combination of these seemingly disparate forms-the gospel of Jesus Christ and rap-as providential, a means through which God intends to reach the post-civil rights, post-R\&B generation. In contrast, its detractors view this amalgamation as sacrilegious. Despite what some view as the oxymoronic nature of holy hip-hop, a closer examination of the testimonies and lyrics utilized by these artists reveals that their approach to the ministry is generation-specific in its packaging but age-old in purpose, that is, it mirrors, in several of its performance elements, as well as in text and intentions, many of the hallmarks of the Black Church and the African diaspora. 


\section{TERMINOLOGY}

There are a number of names by which these performers are known, including holy hip-hop artists, hip-hop gospel artists, Christian rappers, gospel rappers, Christian emcees, and poetic evangelists. However, there are others who prefer simply to be known as hip-hop artists or rappers. Because there is no unanimity regarding the label, in this chapter, I use holy hip-hop (HHH) or Christian rap to refer to the performance genre of all of the artists who use elements of hiphop, especially rap, as a vehicle for disseminating the gospel message.

The reasons why individuals gravitate toward one label and shy away from another are almost as numerous as the artists themselves. Some are reluctant to use anything that announces their affiliation with gospel, because they find they are often dismissed before they can get a fair hearing, particularly by those who think Christian rap would have to be, by definition, tedious and boring or by those who remember the awkward early days of the genre. Others shun what they consider a limiting descriptor, not because they are ashamed of their faith, but because their music often ends up in CD racks next to gospel artists who sing quartet or choir music when they would prefer to be placed with performers like Jay-Z, Kanye West, and other artists who are known for their verbal skills. The consumers that buy that music are the audience they hope to attract.

Among those who have embraced the use of adjectives to designate the kind of rap they present is William "Duce" Branch. A native New Yorker, Branch has been part of the holy hip-hop movement for more than fifteen years, first as half of a Christian rap duo, Children of Life, and then as a founding member and primary spokesperson for the Cross Movement, a highly popular and critically acclaimed Philadelphia-based group. ${ }^{3}$ The Ambassador has perhaps taken more time than most to contemplate what can happen when hip-hop and religion converge, having written his master's thesis, "The Theological Implications of Hip-Hop," at Dallas Theological Seminary. During an interview with Gospelflava.com about his 2005 solo release, "The Thesis," he explained why he finds using modifiers around the word hip-hop a positive step for those who minister through this musical form.

First of all, the Bible has not called us to destroy everything in the world ... Placing an adjective on it has altered this Hip Hop. We have termed it Christian Hip Hop or Holy Hip Hop. That's our way of changing it. So we don't change Hip Hop. That's just another earthly topic. We've modified it. Some people don't want to place Holy or Christian in front of it. They just want it to be Hip 
Hop. We have done it because we believe that the modification in light of what Hip Hop is makes you think. When you hear it, you think of all the things that are not related to God. We gladly added the term Christian to Hip Hop to let them know to expect something different from us. ${ }^{4}$

The term Holy Hip Hop has been attributed to two men, Danny Wilson and eDDie Velez ("Da Preachin Puerto Rican"), who founded a conference and awards program in the late 1990s. On their Holy Hip Hop Web site are the following words: "Our mission statement, since 1997, is to Take the Gospel to the Streets through the global proliferation of Spiritually-Enlightening Holy Hip Hop Ministry, Music \& Entertainment Glorifying Christ." ${ }^{5}$ Over the years, a number of Christian rappers and fans, including many not officially affiliated with the organization, have come to embrace the term. Since its founding, Wilson and Velez's Holy Hip Hop ministry has grown to encompass a weekly syndicated radio program; a series of compilation CDs called Holy Hip Hop: Taking the Gospel to the Streets, distributed by EMI and featuring Christian rappers from around the country; and alliances with a variety of other individuals interested in promoting Christian rap. ${ }^{6}$

There are those who disagree with The Ambassador and the founders of the Holy Hip Hop ministries about the use of adjectives to describe the genre. Among them is Detroiter Jason Wilson, who previously performed and produced secular hip-hop as a member of Kaos and Mystro. The duo was popular throughout the Midwest in the 1980s and early 1990s and even had spot dates as the opening act for Public Enemy, whose music they sometimes sampled. After rededicating his life to God, Wilson thought he would have to leave hip-hop behind, until he heard, through the performance and ministry of The Ambassador, that rap could be used effectively and artistically by Christians. ${ }^{7}$ Today, using the name Maji, Wilson is a founding member of The Yuinon (pronounced "union"), which brings together various artists, producers, and others who see rap as an evangelistic tool. He has produced gospel-themed hip-hop for locally based and national artists, including The Ambassador. His response to the question of nomenclature was this:

I try not to use any terms besides Hip Hop. Because of those titles ["holy," "Christian," etc.] "holy" hip hop has limited its territory and hindered its possibilities to be effectively used as a tool for ministering to the unsaved. When Eric B \& Rakim came out, no one referred to their brand of music as " 5 Percenter" Hip Hop. Or when Public Enemy came out, no one referred to their music as 
"Black Power" Hip Hop. It was just Hip Hop. So I simply call our genre Hip Hop. But the individuals who rap are Christians. ${ }^{8}$

It is worth noting that while Maji personally avoids using certain adjectives, the Web site for The Yuinon states that their recording division strives to produce "quality Christian hip-hop music that will challenge, encourage and address heartfelt needs and social issues."

Still another Detroiter offers a different perspective. Kimberly Williams, a seventeen-year veteran of the gospel music industry, was introduced to presenting the gospel publicly as part of her family's traditional singing group and as an instrumentalist for her father's church. The founder of G-Praize Music, a full-service marketing and promotions company, she has represented a variety of national artists, including Lisa McClendon and many performers who are part of Cross Movement Records. In the 1990s, she worked for Crystal Rose Records; while there, in 2003, she coordinated the nationally released compilation Pure Flava/Pure Gospel, featuring urban and hip-hop gospel performances. ${ }^{10}$ Williams, who raps and performs spoken word under the name Kiwi, calls what she performs "Christian hip-hop."

I think it flows better with any other genre we have-gospel jazz, Christian rock. I think the term holy hip hop is over the top. Maybe it's my upbringing and the whole "holier than thou" thing. I think your lifestyle and your lyrics and ministry will speak for itself. That goes back to the argument that some present to "just call it hip hop." After all, you don't say "Christian boxer."11

\section{CULTURAL AND HISTORICAL LINKAGES}

According to such scholars as Teresa L. Reed and Anthony B. Pinn, there has always been an intertwining of the sacred and the secular in Black music, despite the consternation that the fusion has often created. ${ }^{12}$ Reed traces this melding to the African continent, where there was no sacred/secular dichotomy prior to contact with Western mores. ${ }^{13}$ Religious themes have often surfaced in Black secular music, whether one examines the lyrics of work songs, blues, jazz, R\&B, or soul. Similarly, the Negro spiritual and traditional and contemporary gospel music owe much to their secular cousins, since each form has a nonsacred counterpart, including the "gospel blues" that bluesman turned gospel pioneer Thomas A. Dorsey created and the contemporary sounds of gospel made famous by Edwin Hawkins and Andrae Crouch, which were heavily influenced by 
the $R \& B$ and jazz they heard as teens in California. Of course, the list of contemporary performers who were trained in the Black Church and whose vocals reflect that influence includes such notable figures as Aretha Franklin and Al Green as well as Beyonce Knowles and Fantasia. ${ }^{14}$

The importance of the spoken word throughout the African diaspora is another reason rap and gospel music were bound to cross paths. Linguist Geneva Smitherman writes that admiration for those who handle language with dexterity and power has its roots in Africa, where respect for the well-turned phrase and the phrase turner is pervasive. The oral tradition, then, as Smitherman describes it in Talkin and Testifyin, is one of the cultural elements the African brought to the New World, a component that has survived both the Middle Passage and four centuries of contact with European-Americans. She explains,

The pre-slavery background was one in which the concept of Nommo, the magic power of the Word, was believed necessary to actualize life and give man mastery over things ... In traditional African culture, a newborn child is a mere thing until his father gives and speaks his name. No medicine, potion, or magic of any sort is considered effective without accompanying words. ${ }^{15}$

The reverence for competent speakers within the Black Church tradition connects the contemporary African American with his forerunners who worshiped in the praise houses and "invisible churches" of two centuries ago. Within the slave community, there was an ample supply of impressive speech, much of it generated by the Black preacher who was held in high esteem because of his rhetorical prowess. ${ }^{16}$ In God's Trombones, poet James Weldon Johnson pays tribute to these traditional Black "sons of thunder," as they were often called.

The old-time preacher of parts was above all an orator, and in good measure an actor. He knew the secret of oratory, that at bottom it is a progression of rhythmic words more than it is anything else. Indeed, I have witnessed congregations moved to ecstasy by the rhythmic intoning of sheer incoherencies. He was a master of all the modes of eloquence. He often possessed a voice that was a marvelous instrument, a voice he could modulate from a sepulchral whisper to a crashing thunder clap. ${ }^{17}$

Because this affection for verbal prowess runs throughout African American history and culture, individuals who are as different as "preachers and poets, 
bluesmen and Gospel-ettes, testifiers and toast-tellers, reverends and revolutionaries" are unified in their ability to "rap" and by the community's appreciation of their gift. ${ }^{18}$

Even a superficial glance at the history of the traditional Black Church reveals a deep reverence for the speaker and the spoken word. The apex of the worship event is, of course, the preaching of the sermon, or the delivery of "the message," usually by the pastor or spiritual leader of the congregation, as documented by such researchers as Arthur Paris in Black Pentecostalism and Walter Pitts in Old Ship of Zion, who examines the Afro-Baptist worship experience. ${ }^{19}$ Everything that comes before the sermon-the devotional service, with its uttered prayers and testimonies, as well as the music from the congregation and choirs-paves the way for this pivotal juncture of the worship, according to Paris's research. ${ }^{20}$ As a Baptist pastor's daughter, I have attended countless church services and made note of the fact that there is often a special stance taken by the members of the usher board as the sermonic Bible scripture is read and as the pastors "take their text," that is, as they announce the title and direction of their message. The ushers prevent departures and entrances of any kind during that period, and they often stand in a linear formation, cross right hand over left, and then place both over their hearts in indication of the sacredness of the moment.

As for the preachers themselves, special designations are given to those who are particularly adept at delivering the sermon according to cultural guidelines. A particularly competent preacher may be described as a "whooper" (a term that refers to a particular style of preaching and a unique sound made during the process), a "bench walker," or "somebody's preacher" (that is, a competent minister whom people gladly claim as their own). Grace Sims Holt, in the article "Stylin' Outta the Black Pulpit," offers the terms soul jerkers and spellbinders as descriptive titles given to Black preachers who use a range of rhetorical devices in order to captivate their audiences. ${ }^{21}$

Those who protest the fact that holy hip-hoppers utilize the vernacular to minister to their generation should consider that the successfully performed Black sermon usually contains what Gerald Davis calls "the weighted secular factor." Davis argues that the traditional Black sermon is rooted in "an identifiable African American aesthetic system, or systems," one which supports the production and perpetuation of both folk and popular performances. ${ }^{22}$ After evaluating sermons by a number of Black preachers, Davis reported that there are indeed specific characteristics for the performed traditional Black sermon. These sermonic elements (with provisions made for 
individual innovation) include a primary focus on language and meter, as exemplified by syntactic harmony, repetition, parallelism, and rhyme; ${ }^{23}$ elaboration and illustration achieved through the use of independent narrative blocks that are linked by thematic "bridges"; ${ }^{24}$ the utilization of vernacular and contemporaneity, otherwise known as "the weighted secular factor", ${ }^{25}$ and the employment of sermonphones, including the single word, the phrase, the nonarticulated sermonphone (grunts, groans, and hums), and the sound-absent sermonphone-all of which serve a variety of semantic purposes. ${ }^{26}$ While some of these elements are virtually synonymous with the performed traditional Black sermon, many of these rhetorical devices are also at the heart of what the most skilled Christian rappers deliver to their audiences.

Over time, gospel music performers created their own speech traditions. In fact, Pearl Williams-Jones and Mellonee Burnim demonstrated, in their separate research, that gospel music is comprised of Black forms of music, dance, and spoken word. ${ }^{27}$ The speech practices include, but are not confined to, song introductions, testimonies that might be interjected at any point within a song, the work of gospel radio announcers and live-event emcees, narratives such as those told by the extraordinary storytellers Shirley Caesar and Dorothy Norwood, and call-and-response patterns used to involve congregations in musical program or services. ${ }^{28}$ The oral customs also include the use of prayers and scriptures for a variety of reasons, among them the transformation of otherwise secular spaces, such as auditoriums and amphitheaters where gospel concerts are presented, into "churches." ${ }^{29}$ The phrases are often a combination of words taken from Black sacred repertoire as well as idiomatic expressions from Black secular culture that constitute what Smitherman refers to as "Black Semantics." ${ }^{30}$ Since the mid-1980s, the gospel community has often heard those expressions presented in the form of rap.

\section{THE CONVERGENCE OF HIP-HOP AND GOSPEL}

Holy hip-hop can be seen as a logical, virtually inevitable continuation of historical speech and musical patterns within the Black community in general and the Black Church community in particular. "Indeed," writes Horace C. Boyer, "many gospel music lovers insist that African American preachers were the first rappers and that gospel rappers have been long overdue." ${ }^{11}$ Simultaneously, it is a sacred adaptation of what the Sugar Hill Gang first commercialized in 1979 with the release of "Rapper's Delight." By the mid-198os, the "long overdue" experiments with holy hip-hop began. The late Tim Smith, a Detroit-based pio- 
neer in playing holy hip-hop on radio and a writer for several national music publications, responded to the question of his earliest memories of Christian rap by recalling Scott Blackwell, a prominent club DJ in New York, taking a sermon and putting beats behind it in the 1980s. "It was so cool," he remembered. "And it's like, 'This is what I hear on Sunday morning. Same thing.'" 32

Both the allmusic.com Web site and Breakaway online magazine place Stephen Wiley and Michael Peace as the pioneers of Christian rap, with their respective Bible Break and Rock It Right albums. ${ }^{33}$ In a one-line summary of Wiley's contributions placed on allmusic.com, Bill Carpenter, author and music reviewer, calls Wiley's work "lightweight." ${ }^{34}$ Smith, who recalled that Wiley wore suits when he performed, described his raps as having a "homogenized" sound: "It didn't have the heavy beats that you hear from Gospel Gangstaz [a popular HHH group], people like that. It sounded like 'Mary Had A Little Lamb' with uh, you know, I'm being real! It sounded like 'Mary Had A Little Lamb' with a bit of an edge to it. And that was our introduction to Christian rap." ${ }^{35}$

Whatever some may have felt Wiley's performances lacked, there was apparently a market for it, since its sales placed it among the top five on the CCM (Contemporary Christian Music) charts, as Smith remembered. Michael Peace, just a bit later in the 1980s, introduced the "hard-edge" rap sound for that time, marked by what Smith described as his "beats, his delivery ... his street look." ${ }^{36}$ Not readily received by the church, Peace reached out to those on the streets and worked with urban ministers and rapped to youth in schools, gyms, and anywhere else they would have him. ${ }^{37}$ Eventually, Kiwi recalls, these earliest gospel rappers were followed by a new generation, many of whom were signed to record deals: A-1 Swift (Gospocentric Records/B-Rite Music), Transformation Crusade (Benson Music), dc Talk (Forefront Records), and E.T.W.-End Time Warriors (Forefront Records). ${ }^{38}$

In their willingness to stand on street corners and evangelize if necessary, many of those who are involved in holy hip-hop are a link to the past. From its emergence at the end of the nineteenth century through much of the first half of the twentieth century, gospel music was used primarily as an evangelistic tool within the context of church services, of course, but also during outdoor revivals, tent meetings, and other less-structured settings. ${ }^{39}$ Many of today's Christian rappers continue that tradition of "takin' it to the streets" for at least two reasons: it allows them access to youth who would not ordinarily walk into churches, and it provides alternative platforms for their alternative ministry. Today, unlike the early days of $\mathrm{HHH}$, where the majority of sanctuaries were closed to them, the venues that welcome Christian rappers are multiplying every year. Both mainstream and Christian media, including the New York 
Times and Charisma, corroborate what I have found in my own research: churches around the country are now sponsoring holy hip-hop artists and services and even starting their own record labels in order to support the talented youth from their congregations. ${ }^{40}$ These churches, along with the various music concerts, festivals, and conferences that feature $\mathrm{HHH}$, have helped the genre to attract a wider audience. ${ }^{41}$

\section{PRIMING THE MAINSTREAM FOR HOLY HIP-HOP}

The artist who has assisted $\mathrm{HHH}$ the most in commanding more attention from mainstream media and conservative churchgoers is Kirk Franklin. This composer, arranger, producer, pianist, and rapper (he only occasionally sings) has a backstory that is dramatic enough to be adapted for the big screen, which is in the planning stage. Neglected by his teenage mother, he was raised by his great aunt and uncle. Mesmerized by his uncle's piano playing, Franklin himself began playing by the time he was four. Taken to church by his great aunt several times a week, he was already directing, playing piano, and arranging for choirs when he was a teenager. "Acting out" in a variety of ways to prove that he was as tough as the bigger guys despite his slight stature, he became a teen parent and a high school dropout. Despite these detours, his prodigious talents caught the attention of Milton Biggham of the Georgia Mass Choir and Gospel Music Workshop of America, Inc. But it was when he met Vickie Mack Lataillade, founder of Gospocentric Records, that history was made. ${ }^{42}$

Franklin has reportedly sold twelve million recordings, making him the most successful gospel artist in contemporary history. ${ }^{43}$ His music ranges from his first hit single, a ballad called "Why We Sing," to his song with the widest crossover appeal, "Stomp," from the recording God's Property from Kirk Franklin's Nu Nation, which reportedly sold 4.5 million copies and layers old George Clinton funk, rap, and a gospel message. His album The Nu Nation Project (Gospocentric Records, 2001), the first recording by a gospel artist to ship platinum, typifies the urban, in-your-face, not-your-mother's gospel music Franklin has produced.

Like his "hip, 'singing'" colleagues, including Mary Mary and Tonex, Franklin has been mistaken by the public as a hip-hop artist. ${ }^{44}$ Undoubtedly, these and similar gospel performers include elements of hip-hop in their presentations, including rap, attire, and dance. However, as is the case with his singing peers, the majority of Franklin's music is appropriate for and widely used in thousands of Black churches during the Sunday morning worship experience. His being viewed as an $\mathrm{HHH}$ performer is understandable, since 
some of his biggest hit singles (e.g., "Stomp" and "The Revolution") reflect his upbringing as a self-described "church boy" as well as his earlier career as a break-dancer known as "Kid Fresh."

"The Revolution," from The Nu Nation Project, is a prime example of how Franklin visually and textually has layered the traditional gospel message with hip-hop elements. The young people with whom I conducted feedback interviews reported that both the $\mathrm{CD}$ version and the video work to attract hip-hop "headz" for several reasons: the incessant beats are there, it has the look of an $\mathrm{R} \& \mathrm{~B} / \mathrm{hip}$-hop video (quick cuts, multiple outfits on the main artist, various performance scenarios, and stylized choreography), and the featured rapper is the esteemed hit-making producer Rodney "Darkchild" Jerkins, whose long list of credits includes Michael Jackson, Destiny's Child, and Mary Mary. ${ }^{45}$

Clearly, the hook for the hip-hop lovers-and the distancing device for those who are not-is the attire, the dancers, and the rap. These components allow Franklin to approach a new audience without looking or sounding radically different from them. In two of the three video scenes in "The Revolution," he and the singer/dancers perform with the casual/athletic wear popularized by hip-hop culture. The choreography reflects Franklin's break-dancing career in that it is far more street than sanctuary, without being sexually provocative. The movements are energetic - at some points, the singer/dancers seem to bounce on and off the floor-yet it is never lurid, as both male and female participants are clothed in unisex athletic wear.

However, just beyond these exterior aspects, there are layers of other texts that allow this song to be viewed as an evangelistic tool. Franklin begins the song and video by reciting a verse of scripture and engaging in a verbal exchange with one of the other young men in the production. He delivers words from the King James Version of Revelation 7:16-17 in his most dynamic sermonic style.

They shall hunger no more

Neither shall they thirst anymore...

For God shall wipe away

Every tear from their eye.

Interspersed between these phrases are the kind of Sunday morning responses generally heard in the traditional Black Church while the woman or man of God is delivering the Word. The listener and viewer are told from the onset of the song and video that the focus is ministry through several elements, includ- 
ing the church-appropriate call-and-response and the directive from the young speaker to Franklin to do what he was called to do- "Preach, preacher!" Other texts help to place the song within the gospel music tradition including a rap by Franklin that encompasses some widely held Protestant doctrine regarding the triune nature of God and the divinity of Jesus.

While at least one of the six feedback respondents found the dancing a distraction from the message, she did agree with the other five that the gospel was definitely discernible within "The Revolution." The gospel message is also identifiable within the other hip-hop influenced songs Franklin has recorded, including "Stomp," which features Cheryl Wray, formerly "Salt" of Salt-n-Pepa fame, rapping on the "urban" remix. ${ }^{46}$

\section{THE CROSS MOVEMENT}

Unlike Kirk Franklin, members of the Cross Movement (CM), whose lyrics are at the center of this investigation of Christian rap lyrics, are representative of those who use $\mathrm{HHH}$ as their primary evangelistic tool. Still, they can be viewed as unusual within the genre, in that they have experienced sales and other kinds of success most of their colleagues have yet to garner. The group originally consisted of five young men who were solo Christian rappers until 1995, when they decided to combine their verbal skills and "reach out to persons who were a part of Hip Hop Culture like themselves but did not know God." ${ }^{7}$

The name Cross Movement initially covered three entities that had similar missions but distinct personnel and officers. First was the performing group, currently consisting of four performers-The Ambassador (William Branch), Phanatik (Brady Goodwin), T.R.U.-L.I.F.E. (Virgil Byrd), and The Tonic (John Wells) - and the rap songs they write and perform. Second was Cross Movement Records (CMR), the brainchild of the Tonic and former CM member Earthquake (an original member who now focuses on the label), who created the independent label so that "no one could ever ask an artist signed with the label to 'water down' the Gospel." Besides the namesake group, CMR is also home to rappers Da Truth and Flame and singers J. R. and Michelle Bonilla. Third was Cross Movement Ministries, headquartered in Philadelphia, Pennsylvania, which emphasized teaching and disseminating the gospel and was headed by The Ambassador and Phanatik. ${ }^{48}$ The latter was replaced in 2006 by other initiatives, including ChristIaN Hip-Hopper.com, a Web site that aims to articulate a philosophy for ministry and to serve as a site that groups a number of effective Christian hip-hop ministries. ${ }^{49}$ 
Several music insiders have assessed the Cross Movement to be among the most influential artists within HHH. Kymo Dockett, a writer for What's the Word online magazine, explained, "Whether you judge success based on the number of lives reached for Christ, the number of albums sold, or the amount of projects dropped, Cross Movement have quite remarkable stats on all three fronts." ${ }^{\prime 0}$ The reasons for their three-pronged success are summarized by Jon Corbin: "The difference between this group and previous artists who had made such an attempt was that these guys were actually good."51

\section{THE PERFORMANCE AESTHETIC}

A live or video performance of the Cross Movement—or of any other Christian rap artist or group-initially appears to have the same performance aesthetics of any hip-hop concert: the artists in urban fashion, such as Timbs (Timberland boots), loosely worn jeans, and oversized shirts; a DJ mixer; and a hype crowd of young and young-minded fans, attired like the artists they have come to see, mouthing the words, and with hands raised or pumping the air as their favorite rappers take the mic on an elevated stage. But when I made a presentation to a group of young teens at the Calvary Baptist Church in Salt Lake City, Utah, in 2005 on this topic, I showed several videos, including "When I Flow (It's Gospel)" by CM, “The Revolution," by Kirk Franklin, and "Ste Pon Di Enemy" (Step on the Enemy) by Papa San. When I asked what made the performances holy and not just hip-hop, they replied, "The women have on all their clothes," an obvious reference to the sometimes scantily clothed and sometimes virtually unclothed "video vixens" that usually populate the screen as fully clad male rappers perform.

Kiwi explains, from her vantage point as an artist, what should be holy, sacred, or gospel about the genre: "Lyrics, ministry and lifestyle, what any Christian's lifestyle should be about. Unfortunately, once people think hip hop, their minds will immediately go to what the media portrays hip hop to be, the 40 's, bootie shorts, and gyrating. So, the term is used to give a distinction, 'No, we're not about that. We're about lifting up Christ through this music." ${ }^{52}$ Maji, when asked the same question, responded, "Nothing is holy about our genre, but there are some individuals in it that strive to live a Christian/holy/righteous lifestyle." Because the attire, beats, and presentation are so similar to what is found in nonreligious rap, lyrics become critical, since it is in the text that one finds the message of the gospel. 


\section{THE LYRICS}

Holy hip-hop artists often perform songs in which they describe the sins and conditions from which the Lord has delivered them. In this key way, they are as much a part of the gospel music continuum as any choir members or quartet singer. An oft-repeated floating lyric in the Black Church about having been changed by God is "He picked me up, turned me 'round, placed my feet on solid ground.” In the Cross Movement's song “Rise Up," the group offers a look back at their lives before they accepted Christ and, after doing so, thanks God that they are no longer involved in various "godless" pursuits, as they label them.

And though the world is godless we thank God that God has called us

From being ballers, and players, and pimps and alcoholics

Times are hard but even still we must run our hardest

"Run like Forest," with a limp, but we run regardless! ${ }^{53}$

Just as the apostle Paul could preach from experience about having a lifechanging encounter with Jesus Christ, some members of the holy hip-hop community, including the Cross Movement, can do the same. The Tonic, for example, who told a Washington Post interviewer that he had been a heavy drinker in the past, said during that same interview, "Look at us ... We were violent, we were sexually immoral. We come from that, and look at how we changed. In our eyes, we're walking miracles." ${ }^{4}$ Because they have been changed, they feel compelled to share the good news with others without delay, according to Hebrews 12:1-2: "Run with perseverance the race that is set before us [the believer].”

At the beginning of one of their most celebrated songs, "Blood Spilla”, The Ambassador describes the mission of the group: "We're the Cross Movement, which is an alliance of born again believers in Jesus Christ that are trusting God by His grace to become agents through whom He's gonna advertise salvation and also communicate His purpose for all of humanity." 55 Though it is not the norm for $\mathrm{HHH}$ songs to have a spoken introduction before the artists go into the fast-paced rap that is characteristic of the genre, these opening words from The Ambassador serve as both a mini description of their mission and a spiritual framing device for that which follows. This statement is reflective of what Christians call "the Great Commission," a directive given by Jesus Christ as recorded in Matthew 28:19: "Go ye therefore, and teach all nations." The proof 
that they have this specific objective is conveyed in the song's lyrics, which offer a number of cultural and spiritual allusions, beginning with the application of the words "thrilla' in Manila."

(2X) It's the thrilla' in Manila

Jesus Christ versus every man's killa'

Sin and death's got the whole world gettin' illa'

But I praise God for the Blood Spilla'

Here, the group alludes to the audacious young Muhammad Ali, who, in 1975 as he prepared to fight Joe Frazier, coined the memorable phrase "thrilla" in Manila" and then beat his opponent in a most humiliating fashion. The Cross Movement is using cultural shorthand, making reference to an occurrence that is three decades old, in order to convey their spiritual assessment of the contest between Jesus Christ and the twin adversaries of sin and death. It is a face off that must occur for two reasons: because it is a key Biblical prophecy and because, the group says, the world is getting further away from doing what is right. ${ }^{56}$ Since the face off will result in the eradication of the two ills that destroy mankind, they thank God for Jesus Christ, who will be triumphant over sin and death and who, according to Christian doctrine, shed his blood for the redemption of humankind. He is the one referred to here by $\mathrm{CM}$ as "the Blood Spilla."

Eschatology, the study of the final prophetic events mentioned in the Bible, is another topic to which Christian rappers have applied their skills, as CM does in "Cry No More," one of their most infectious tracks to date. The song is based on Revelations 21, the same section referred to in Franklin's "Revolution," in which the promise is that in the world to come, the faithful will no longer cry, because they will be removed from the sad things of this world and will live eternally in the presence of God.

One day I won't cry no more

Can't wait for the day when people won't die no more

Daddy's won't say, bye no more; lie no more

In the streets bullets won't fly no more

Right after the very singable chorus from which these lines are taken, CM goes into the spiritual reasons for wanting the prophecies to be fulfilled. 
One day we takin' off baby and ever since the Lord saved me

I've been waitin for the day we can say, it's all gravy

It's all crazy tryin to see life when its all hazy

How can I persist to do right when I'm all lazy?

Feel me? Too much pain it all ails me

Vexed, cause I can feel the effects of the Fall daily

The pain in my chest is strong, let's get on

Come Lord, quick, bring on the eschaton

End the search, start the new earth, flex your true worth

Honor your Son, let Him come, perfect the new birth

Within the lyrics lie references to several core Christian beliefs that a listener can follow without a biblical concordance. CM talks about the daily struggles of earthly life that can be traced to "the Fall" of Adam and Eve. However, they explain their belief that there will come a time when this life ends and God's promised new earth will replace the current one, which is one of the central eschatological prophecies of the book of Revelation. ${ }^{57}$ The group does not get embroiled in the pre-, post-, or midtribulation debates that center on whether believers will go through certain challenges during the end times or be spared from them altogether. Instead, they stick to the point on which all of these groups agree: "one day we takin' off baby." "Takin' off" ties into one of the most persistent images in Black folktales and the traditional songs of the Black Church: flying away to escape the troubles of this world. ${ }^{58} \mathrm{CM}$ reminds their listeners that believers in the gospel look forward to the establishment of a new theocratically ruled world ("Honor your Son; let Him come"), where God will give the true believers the ultimate reward for their faith and faithfulness: eternal life with him.

Another prevailing theme in gospel/Christian songs is the love believers have for God, a reflection of 1 John 4:19: "We love Him because He first loved us." It is the same kind of personal love connection depicted in the Cross Movement's "Blood Spilla," which, while focusing on the sacrificial death of Jesus Christ, also articulates the profound reverence, love, and awe the group feels for their Savior because of the price he paid to bring humankind back to God.

I step back to take a chill pill

just to let the thrills build

back up and now I have to say that I still feel 
goo-goo about the one the crew brings to you

died to woo you and bring you back like part two-ooh!

As expressive as these words are concerning the love the group members feel for Christ, they are equally bold later in the song in drawing a line in the sand to challenge those who suggest that their gods are on the same level as the God of the Bible.

If it's your God let him speak

I'll hide let him seek, I'll jump let him leap

Let him swim the deep. Did his blood leak?

Does your god love me?

Will he still propose even though I get ugly?

Can he turn trouble to ease?

Can his love make me "weak in the knees" like SWV?

If he can take the sins of the whole world-swallow' 'em

Experience death then resurrect, then I'll follow him

But if he can't then I'm stayin' with my camp

We a pack of theocrats gettin' amped 'cause our God is champ! 59

Using the language of love affairs, including talk of proposals and "getting weak in the knees," CM delivers lines that are simultaneously clever, vernacular, and accessible. ${ }^{60}$ They are clever in that they take us back to the original allusion to Muhammad Ali and the inevitable fight between God and Satan, vernacular in the description of who the performers are ("we a pack of theocrats gettin' amped"), and therefore accessible in that they are able to attract those who find $\mathrm{HHH}$ at times either too didactic or not as skillfully created as the work produced by secular artists. ${ }^{61}$

As one reviewer explained, "with clever wordplay and quality production, The Cross Movement does not disappoint." ${ }^{2}$ These words can also be applied to many of their peers, including Da Truth, Kiwi, Mahogany Jones, and the artists of Reach Records, two of whom, Lecrae and Tedashii, made unprecedented debuts in the number one and number two slots on the gospel charts with their respective releases Rebel (2008) and Identity Crisis (2009). The "Don't Waste Your Life" tour, featuring these two high-charting rappers, their equally skilled label mates Trip Lee and Sho Baraka, and Cross Movement Records artist Flame, was among the most anticipated and most successful for the genre in 2009. These performers are among those of their generation who have 
learned to balance the message of the gospel with the skills required within rap. Space will not allow the investigation of more lyrics here; those that have been analyzed demonstrate that the work these Christian artists perform is both holy and hip-hop, which makes it a spiritually and culturally important mode of expression worthy of academic investigation.

\section{Notes}

1. For a full discussion of some of the debates surrounding mainstream hip-hop, especially rap music, see Rose, Black Noise, 1-2; Watkins, Hip Hop Matters.

2. Anthony B. Pinn has edited a collection of essays that address the wide-ranging religious dimensions that can be found within rap music. See Pinn, Noise and Spirit.

A handful of individual academic articles investigate the hip-hop/gospel music connection. Garth Kasimu Baker-Fletcher examines and categorizes the rhymes of African American Christian rappers, using the theory that "the Christian message is expressed in rap music through the polarities of oppugnancy [creative forms of resisting oppression] and/or opacity [the tendency of oppressed people to simultaneously live with negativity and oppose it] using religious symbols and language" ("Facing Truth," 30). Guthrie P. Ramsey, Jr., explores the broader hip-hop aesthetic in the performances of such gospel artists as Karen Clark Sheard and Kirk Franklin ("Santa Claus," 190-215). Cheryl Renee Gooch looks at the fact that some Black Church leaders view the use of gospel rap as a complement to other religious music forms ("Rappin' for the Lord," 228-42). In a brief article, Michael Eric Dyson states that rap mirrors the weaknesses and strengths of society; and that examining it more critically would allow the church and others to identify their own shortcomings ("Rap Culture," 268-73).

The present essay differs from these works in that I argue that a close textual analysis of the lyrics of holy hip-hoppers reveals their commitment to delivering the gospel message of their forefathers in an aesthetic package that will attract their contemporaries.

3. Information on Cross Movement Records artists can be found at http://www .crossmovementrecords.com/pages.asp?pageid $=66461$.

4. Lacy, "Ambassador Interview."

5. Found on the home page for Holy Hip Hop.com.

6. Ibid.

7. Jason Wilson ("Maji”), personal interview, Detroit, MI, November 10, 2003.

8. Jason Wilson ("Maji”), email communication, January 31, 2008.

9. "The Yuinon's Mission."

10. Kimberly Williams ("Kiwi"), personal interview, Detroit, MI, January 7, 2004.

11. Kimberly Williams ("Kiwi”), email communication, January 29, 2008.

12. See Teresa L. Reed, Holy Profane, introd.; Pinn, Noise and Spirit, 2-12.

13. Reed, Holy Profane, 1-5.

14. Ibid., 10-13; Pinn, Noise and Spirit, 2-12.

15. Smitherman, Talkin and Testifyin, 77-78.

16. Raboteau, Slave Religion, 237. 
17. Johnson, God's Trombones, 5.

18. Smitherman, Talkin and Testifyin, 76 .

19. Paris, Black Pentecostalism; Pitts, Old Ship of Zion.

20. Paris, Black Pentecostalism, 54.

21. Holt, "Stylin' Outta the Black Pulpit," 196, 200.

22. Davis, I Got the Word, 28-31.

23. Ibid., 51-53.

24. Ibid., 101.

25. Ibid., 61, 105 .

26. Ibid., 98-100.

27. For a full discussion of the defining elements of gospel music, see WilliamsJones, "Afro-American Gospel Music," 373-85; Burnim, "Black Gospel Music Tradition," 164 .

28. For examples of the storytelling tradition within gospel music, see Caesar, "Hold My Mule"; Norwood, "Denied Mother." I examine the work performed by gospel radio announcers/DJs in my article "Gospel Announcers (Disc Jockeys)," 87-101.

29. I discuss how gospel announcers and singers use words to create spatial transformations in my article "Gospel Announcers (Disc Jockeys)," 94-96.

30. Smitherman, Talkin and Testifyin, 42-43.

31. Boyer, "African American Gospel Music," 486.

32. Tim Smith, personal interview, Southfield, MI, September 25, 2003.

33. Breakaway mentioned the two artists as $\mathrm{HHH}$ pioneers at http://www.family .org/teenguys/breakmag/features/aoo20488.html (the current URL for Breakaway is www.korministries.com); allmusic.com presents a one-sentence critique of Wiley, calling him "the original gospel rapper," at http://www.allmusic.com/cg/amg.dll?p= amg\&sql=11:cyec97u7krkt. An equally brief mention of Michael Peace, whom allmu sic.com has debuting in 1987, occurs at http://www.allmusic.com/cg/amg.dll?p= amg\&sql=11:kifyxqq5ldke.

34. Carpenter, "Stephen Wiley."

35. Tim Smith, personal interview, Southfield, MI, September 25, 2003.

36. Ibid., 2003.

37. Ibid., 2003.

38. Kimberly Williams ("Kiwi”), email communication, January 14, 2004.

39. Williams-Jones, "Afro-American Gospel Music," 271, 274; Boyer, "African American Gospel Music," 12-29.

40. See Leland, "Rappers Are Raising"; Gaines, "More Churches Getting in Step"; Pedrotti, "Holy Hip-Hop." Also see Smith and Jackson, Hip Hop Church.

41. The Edwin Hawkins Music and Arts Seminar, the Gospel Heritage Praise and Worship Conference, and the Bobby Jones Retreat have involved urban contemporary artists, including those who perform holy hip-hop, as panelists and performers. The Motor City Praisefest (Detroit, MI) is just one of many gospel music festivals that have made room for Christian rappers to perform.

42. Franklin shares his autobiography that will be the basis for the movie in Church Boy: My Music and My Life.

43. This designation does not include artists such as Aretha Franklin and Amy 
Grant, who sing both secular and gospel. The sales figure was provided by Tracey Artis, vice president of Gospocentric Records, during a 2007 telephone conversation.

44. Kia Jones, electronic communication, December 2004.

45. I conducted feedback interviews on February 3, 2000, while showing "The Revolution" and several other videos to six gospel music fans in Detroit who also serve as choir members, ministers, and/or praise and worship leaders in their churches. The interviewees included Portia J. Dye, Timothy Dye, Kyra D. Edwards, Sean C. Mosley, and DeRonae K. Smith.

46. Franklin, Kirk Franklin Presents God's Property. Lyrics can be found at http:// www.lyricsdomain.com/11/kirk_franklin/stomp.html.

47. http://www.crossmovement.com/start.asp (the current URL for Cross Movement is http://www.crossmovementrecords.com).

48. Ibid.

49. ChristIaN Hip-Hopper.com, June 29, 2006, http://www.christ-in-a-hip-hop per.com/pages.asp?pageid $=38574$.

50. Dockett, interview with Cross Movement.

51. Corbin, review of "Human Emergency."

52. Kimberly Williams ("Kiwi”), email communication, January 29, 2008.

53. Cross Movement, Holy Culture. The complete lyrics can be found at http://www.crossmovementrecords.com/articles_view.asp?articleid $=8341 \&$ colum nid $=1321$.

54. Segal, “Rap That MTV Won't Play," G1.

55. Cross Movement, Heaven's Mentality. The lyrics for "Blood Spilla" " can be found at http://www.lyricsbox.com/cross-movement-lyrics-blood-spilla-qsp4fnv.html.

56. Genesis 3:15 forecasts this confrontation when God says to Satan, "I will put enmity between thee and the woman, and between thy seed and her SEED. It shall bruise thy head, and thou shall bruise His heel." It is also to be found in many of the eschatological (end time) scriptures found in Revelation that the Cross Movement and other $\mathrm{HHH}$ groups reference frequently.

57. See, for example, Revelation 21:1: "And I saw a new heaven and a new earth: for the first heaven and the first earth were passed away; and there was no more sea."

58. For example, it is the mode of escape used by the slaves in the folktale retold in the book The People Could Fly, by Virginia Hamilton. The song "I'll Fly Away," a congregational song that has also been performed in traditional and contemporary gospel forms, contains the words: "One glad morning when this life is over, I'll fly away. To a land on God's celestial shore, I'll fly away ... Just a few more weary days and then, I'll fly away. When I die, Hallelujah by and by, I'll fly away."

59. Cross Movement, Heaven's Mentality.

6o. The phrase "weak in the knees" is an old description of an individual's response to his or her beloved as well as the title of a song made popular in 1992 by the R\&B girl group SWV (Sisters with Voices), which is referenced in the lyrics.

61. For a highly satirical look at how difficult deciphering some Christian rap lyrics has been deemed by some, see "Christian Hip-Hop Artist's Lyrics Too Theologically Complex for Rap Fans," http://www.holyobserver.com/detail.php?isu=vo2io1\&art=dawgma.

62. Capulong and North, "Cross Movement." 


\section{Bibliography}

Ambassador. Interview by Dwayne Lacy. Gospelflava.com, 2005. http://www.gospelflava .com/articles/ambassadorinterview2005.html (accessed June 26, 2006).

Baker-Fletcher, Garth Kasimu. "Facing Truth and Resisting It." In Noise and Spirit: The Religious and Spiritual Sensibilities of Rap Music, edited by Anthony B. Pinn. New York: New York University Press, 2003.

Boyer, Horace C. "African American Gospel Music." In African Americans and the Bible, edited by Vincent L. Winbush. New York: Continuum, 2000.

Burnim, Mellonee. "The Black Gospel Music Tradition: A Complex of Ideology, Aesthetic and Behavior." In More than Dancing, edited by Irene V. Jackson. Westport, CT: Greenwood, 1985.

Capulong, Maria, and Stan North. Review of Cross Movement's Higher Definition. Gospelflava.com, n.d. http://www.gospelflava.com/reviews/crossmovementdefini tion.html (accessed November 12, 2004).

Carpenter, Bill. "Stephen Wiley." Allmusic blog. http://www.allmusic.com/cg/amg .dll?p=amg\&sql=11:aifexqq5ldoe.

"Christian Hip-Hop Artist's Lyrics Too Theologically Complex for Rap Fans." Holy Observer, May 15, 2004. http://www.holyobserver.com/detail.php?isu=v02io1\&art= dawgma.

ChristianHipHopper.com. http://www.christ-in-a-hip-hopper.com/.

Corbin, Jon. Review of Cross Movement's Human Emergency. cMusicWeb.com, July 2002. http://cmusicweb.com/hiphop/crossmovement/humanemergency.shtml.

Cross Movement, interview by Kymo Dockett. What's the Word, 2004. http:// wtwmagazine.com/cross_movementinterview.htm (accessed April 10, 2006).

Cross Movement Records home page. http://www.crossmovementrecords.com/pages .asp?pageid $=66461$.

Davis, Gerald L. I Got the Word in Me and I Can Sing It, You Know. Philadelphia: University of Pennsylvania Press, 1987.

Dyson, Michael Eric. "Rap Culture, the Church, and American Society." Black Sacred Music: A Journal of Theomusicology 6, no. 1 (1992): 268-73.

Franklin, Kirk, with Jim Nelson. Church Boy: My Music and My Life. Nashville: Word Publishing, 1998.

Gaines, Adrienne S. "More Churches Getting in Step with Hip-Hop Music." Charisma, August 2003.

Gooch, Cheryl Renee. "Rappin' for the Lord: The Uses of Gospel Rap and Contemporary Music in Black Religious Communities." In Religion and Mass Media: Audiences and Adaptations, edited by Daniel A. Stout and Judith M. Buddenbaum, 228-42. Thousand Oaks, CA: Sage Publications, 1996.

Hamilton, Virginia. The People Could Fly. New York: Knopf, 2004.

Holt, Grace Sims. “Stylin' Outta the Black Pulpit.” In Rappin' and Stylin' Out: Communication in Urban Black America, edited by Thomas Kochman. Urbana: University of Illinois Press, 1972.

Holy Hip Hop.com. http://www.holyhiphop.com/ (accessed January 30, 2008).

Johnson, James Weldon. God's Trombones. 1927. Reprint, New York: Viking Press, 1976. 
Leland, John. “Rappers Are Raising Their Churches' Roofs.” New York Times, September 13, 2004.

Paris, Arthur. Black Pentecostalism: Southern Religion in an Urban World. Amherst: University of Massachusetts Press, 1982.

Pedrotti, Kay S. "Holy Hip-Hop: Saturday Night Gathering Captures Teen Talent, Emotions." Lutheran, July 2003. http://www.thelutheran.org/article/article_buy.cfm?arti cle_id=4030.

Pinn, Anthony B. Noise and Spirit: The Religious and Spiritual Sensibilities of Rap Music. New York: New York University Press, 2003.

Pitts, Walter F. Old Ship of Zion: The Afro-Baptist Ritual in the African Diaspora. New York: Oxford University Press, 1993.

Pollard, Deborah Smith. "Gospel Announcers (Disc Jockeys): What They Do and Why It Matters." Arkansas Review: A Journal of Delta Studies 31, no. 2 (August 2000): 87-101.

Raboteau, Albert J. Slave Religion. New York: Oxford University Press, 1978.

Ramsey, Guthrie P. “Santa Claus Ain't Got Nothing on This! Hip Hop Hybridity and the Black Church Muse.” In Race Music: Black Culture from Bebop to Hip-Hop, 190-215. Berkeley: Center for Black Music Research, 2003.

Reed, Teresa L. The Holy Profane: Religion in Black Popular Music. Lexington: University Press of Kentucky, 2003.

Rose, Tricia. Black Noise: Rap Music and Black Culture in Contemporary America. Hanover, NH: University Press of New England, 1994.

Segal, David. “The Rap That MTV Won't Play; Hip-Hop's Christian Contingent, Finding the Lord but Still Looking for Success." Washington Post, October 22, 2000, G1.

Smith, Efrem, and Phil Jackson. The Hip Hop Church: Connecting with the Movement Shaping Our Culture. Downer's Grove, IL: InterVarsity Press, 2005.

Smitherman, Geneva. Talkin and Testifyin: The Language of Black America. Boston: Houghton Mifflin, 1977.

Watkins, S. Craig. Hip Hop Matters: Politics, Pop Culture, and the Struggle for the Soul of a Movement. Boston: Beacon Press, 2006.

Williams-Jones, Pearl. "Afro-American Gospel Music: A Crystallization of the Black Aesthetic." Journal for the Society of Ethnomusicology 19, no. 3 (September 1975): 373-85.

"The Yuinon's Mission." The Yuinon. http://www.theyuinon.com/about/index.htm (accessed January 30, 2008).

\section{Discography}

Caesar, Shirley. Live in Chicago with Rev. Milton Brunson and the Thompson Community Singers. Rejoice Records, 1988.

Cross Movement. Heaven's Mentality. Cross Movement Records, 1997.

Cross Movement. Holy Culture. Cross Movement Records, 2003.

Franklin, Kirk. Kirk Franklin Presents God's Property. B-Rite Music, 1997.

Norwood, Dorothy. Dorothy Norwood and the Combined Choir of Atlanta, Georgia: "The Denied Mother." Savoy Records, n.d. 

PART TWO: DANCE 



\section{Rhythmic Remembrances}

\section{YVONNE DANIEL}

RÍTMOS, RITUALES Y RECUERDOS DE LA SABIDURÍA

Antes de bailar, cantar o tocar, hay ritmos, rituales, y recuerdos.

Antes de bailar, cantar o tocar los tambores, tenemos que saludar a Elegba, Elegbara,

el niño de negro y rojo y de la diversión y abiertas.

Es el que nos da permiso a cruzar la puerta $y$ comunicar bailando.

Es el al principio que nos ofrece la sabiduría del baile.

[Before dancing, singing, or drumming, there are rhythms, rituals, and memories. Before dancing, singing, or playing the drums, we must greet Elegba, Elegbara, the playful child of black and red. It is he who gives us permission to cross the doorsill and communicate spiritually as we dance.

It is he who first offers us dancing wisdom.]

In the dancing and music-making communities that I study, I see power, endurance, joy, and rapture; I see this in the visual display of worshiping, performing, believing dancers and musicians. When I witness the most common scenes of ritual performance in Haiti, Cuba, or Brazil, I am reminded of a stage full of Chicano couple dancers in California's Cinco de Mayo celebrations, large groups 
of young Irish girls performing to bagpipes on St. Patrick's Day in Massachusetts, and hundreds of Pacific Islanders performing traditional hula in San Francisco at the Ethnic Dance Festival. These are all, like my study groups, large ensembles enacting unison dance movement, and it is awesome as well as curious.

When unison movement is augmented exponentially in hundreds of performers, as it is in these secular, civil celebrations, the viewer is privy to a greater sense of what many dancing and believing ritual performers experience as they express themselves bodily in religious celebrations. ${ }^{1}$ Where there is ensemble movement based on a unison dance vocabulary, there is doubled and tripled power, vivid and often chilling dance/music expression. The ritual communities I have lived among have been performing as a unified ensemble with the same movements to the same rhythms for centuries. This essay focuses on those rhythms and deciphers rhythmic significance over time in the African diaspora. ${ }^{2}$

My field research has unfolded what I call "embodied knowledgeS," many sorts of knowledge within performance, such as botany, philosophy, physiology, psychology, history, mathematics, ethics, gastronomy, music, dance, and so on. ${ }^{3}$ While my companions within ritual communities do not name this knowledge as I do, I cannot avoid the standard disciplines that this knowledge references in nonritual institutions and societies. Since I am sharing what I have learned about different values and behaviors with members from my own society, I use the meaningful terminologies and relevant analogies of my society in an effort to explain understandings from other societies. In this essay, I concentrate on rhythm in danced, sung, and drummed knowledge in the religions of Haitian Vodou, Cuban Yoruba, and Brazilian Candomblé.

\section{OVERVIEW OF AFRICAN-DESCENDED RELIGIONS}

In ritual contexts of Haiti, Cuba, and Brazil, strong belief systems initiate regular, routine ceremonial performances. ${ }^{4}$ The ceremonies that have developed concentrate heavily on either the human body or the suprahuman body - that is, a human body that has been transformed by a spiritual incorporation. The communities meet according to a ritual calendar and form a mass of dancing bodies in periodic ceremonies. The dancing bodies accumulate intensity, energy, and spirit; they display power and enact, as well as disseminate, knowledge. Worshiping performers reenact what they have learned, what they have been told, what they feel, and what they imagine. They re-present spiritual understandings that are held within religious families, temples, or "houses."

Haitian famis, Cuban familias de santo, and Brazilian terreiros da santo are 
extended ritual families that are re-created in the image of a consanguine and religious ideal. In the countryside as well as in urban areas of these three sites, a head of household or a formally elected member of the ritual community serves as ritual leader, healer, and diviner for his/her blood relatives, many adopted members, and a few honorific members. It is within the ritual family, small or large, that proper performance instruction takes place.

The historical circumstances of enslaved African descendants have created a deep reliance on the abstract expressiveness of the dancing body and on nonverbal, communicative procedures. Meaning registers within visceral responses to kinesthetic and musical affect. ${ }^{5}$ As worshipers perform, they sense and learn. As they continue to perform over time, embodied knowledge is deciphered and consulted. For example, community members are first exposed to specific elements and processes that give general ritual knowledge. They are taught chants in archaic ritual language; they are introduced to unaccompanied drumming, as well as drumming with an array of dance sequences. They are encouraged to have a formal familiarity with flowers, plants, and herbs (including their specific placement in- and outdoors, their uses for bathing, and their recipes for drinking). They are taught distinct body manipulations (codified handshakes, turning salutations, bows, and other gestures on the floor). Also, members sustain short and long periods of isolation and quiet.

When the silence is broken, they are often asked about the bodily sensations they have experienced. Inevitably, community members are directed indirectly to survey what the body is communicating and to give voice to its mute delivery. The introduction of specific ritual elements, the inquiry, the focus on quiet, and the assessment of bodily discoveries all result in an ongoing method of observation, referencing, and periodic consulting. There is a dynamic, practical, current-referencing of the body that can mean many things over a lifetime of performance and reflection.

The general objectives of dance/music ritual are to achieve balance between the spiritual and human worlds, to praise the supreme Divinity and celebrate divinities, to gain individual strength and dignity, and ultimately to maintain and secure the social solidarity of the ritual community. The methods used to accomplish these objectives are instrumental and vocal music-making, dancing, praying, and spiritual transformation. One of the by-products of these efforts is awareness of stored knowledge within the dancing and music-making body. Over time, the musicians and dancers, those whom I call the "experiential librarians" of ritual practice, become consciously aware of the vast knowledge that exists within African diaspora religious performance. 


\section{EMBODIED RHYTHMIC KNOWLEDGES}

Experiential librarians store understandings and perspectives inside their bodies. They contemplate on and digest the knowledge that is found in observation, practice, and communal rituals. They sing, drum, and dance the codified and sequenced rhythms of the ancestors and provide opportunities for others to experience and learn.

\section{Chants, Songs, and Singing}

Through regular performances over time, whole and abbreviated texts of ritual prose and poetry have been repeated and passed on in prayers, but mainly in chants and songs of African nations. Many versions of these were conserved by the continuous input of arriving Africans in the transatlantic slave trade from the sixteenth to the late nineteenth centuries.

The Spanish and Portuguese initiated Africanness in the Americas, but they were not alone. ${ }^{6}$ The Spanish brought ladinos, or Afro-Spanish descendants, from the European immersion in African culture for over five hundred years, that is, through "Moorish" descendants in Spain and by means of their early exploration of both island and mainland territories of the Americas. Portugal intervened in continental African slavery and spread it north to Portugal and Madeira and eventually west across the Atlantic Ocean. ${ }^{7}$ Portuguese forts at Sao Tomé and "Angola" (now Gabon to Zambia) held supplies of Africans coming from Upper Guinea (now Senegal to Sierra Leone) from 1441 to 1700 . Africans from Lower Guinea (now Sierra Leone to Cameroon) and "Angola" were the main sources for human trade from 1700 to $1888 .{ }^{8}$ However, the Danes, the French, the English, and the Dutch were also heavily involved in the Atlantic slave trade. ${ }^{9}$ As a result of the continuous flow of African cultures, customs, and values across the Americas for four centuries and despite the horrific interruption to hundreds of African cultures, worshiping practitioners were able to retain many African chants and songs in the Americas. They did not always understand the lyrics in African languages, since the enslaved were often forced to take on the languages of the colonizers. ${ }^{10}$ Still, hundreds of songs and chants in African languages and some in European languages are sung as central elements in all three religious sites. ${ }^{11}$ The accumulated plant knowledge of the African-descended community can be found within the lyrics of this vocal literature; that is, ritual chants and songs reveal an embodied botany.

Plant knowledge spread from African herbalists to the larger African-de- 
scended community as medicinal knowledge; however, plant knowledge spread not only through ritual specialists but also through community singing of rhythmic texts and repeated religious stories. African descendants retained specific words, word concepts, and religious poetry that referenced plants. They adapted practices that were associated with the words and understandings, although in new contextual orders and perhaps occasionally with new meanings.

Embedded in the archaic and evolving African languages of ritual chantsand, importantly, also in ongoing social instruction - were references to the attributes of plants and their relationship to behaviors, characteristics, and preferences of cosmic divinities. Rhythmic singing of religious chants connected divine understandings and plant life. Sung rhythmic references kept religious history alive and simultaneously reinforced belief in cosmic divinities, their attributes, leaves, and herbs. In effect, the chants maintained knowledge for wellbeing and health by referencing botanical information that could be used for medicinal purposes. While ritual chants functioned musically to initiate the forward progress of a ceremony, they also functioned educationally to connect specific plant names and medicinal properties to specific African divinities.

In the research findings of Michel Laguerre and Harold Courlander for Haiti, Pierre Verger and Robert Voeks for Brazil, and Lydia Cabrera and Morton Marks for Cuba, we find lush examples of codified plant knowledge. ${ }^{12}$ Regarding Cabrera's vast contributions, ethnomusicologist Morton Marks says,

A complete botanical entry in Lydia Cabrera's El Monte thus consists of a Spanish common name, a scientific classification, the plant's Yoruba and Kongo names, and an orisha "owner."

Afro-Cuban herbalists knew the orisha owners, ritual applications, and curative powers of hundreds of trees, roots, barks, grasses, herbs, vines and flowers. In their exploration and classification of the Cuban forests and savannas, they were undoubtedly guided by the cognitive categories anthropomorphized as the "orishas." 13

Also through the translations of Yoruba chants to English by John Mason, we know that the chant liturgy is filled with oricha details including associated leaves and herbs and favored plants. ${ }^{14}$

In fact, the sung chant texts in each of the three sites made botanical information declarative; rhythmic singing of chants and songs made the texts forceful enough to be remembered and effective enough to assist healing and curing practices. ${ }^{15}$ The rhythmic remembrances within sung rituals of Haiti, Cuba, 
and Brazil have helped to maintain botanical references as embodied botany within their sacred mission.

\section{Drumming}

Dance analysis and cultural interpretation of ritual performance indicate that ritual music is predicated on a body of mathematical knowledge that was linked to it ages ago. ${ }^{16}$ In order to maintain the rhythmic relationships that structure and ignite spiritual transformations in ritual performance, important intervallic relationships and sequences are linked in the vital rhythmic content of liturgical music. I call this linkage "buried mathematics," the recessed or hidden mathematics of African-descended drumming traditions. I am referring to a fundamental rhythmic relationship between the tones or intervals that are heard in liturgical drumming. This relationship comprises the sequences of rhythms that render shape, form, and content to the religious drum traditions of Haiti, Cuba, and Brazil.

Musical relationships can be reduced to numerical expressions in the analysis of drum traditions. When pitches or tones of a drum are sounded, they are understood primarily in terms of musical relationships; however, they can also be expressed as intervallic, numerical, or ratio relationships. When the batá are readied for playing, for example, ideally their larger heads, or enus, and the smaller heads, or chachas, do not have the same pitches. All three drums (Iya, Okonkolo, and Itotole) are tuned by the shape of the drum itself, the stretch, tension, or predetermined inner dimensions of the skins, in relation to one another. If the enu of the itótole is the same pitch as the chacha of the okónkolo, drummers perceive the tone as "low" and tend to tighten the head of one or the other, so that there is a distinction (a "personalized sweetness") that characterizes each pitch. In mathematical terms, the drums have an intervallic relationship, that is, a second (2nd), a third (3rd), a sixth (6th), and so on, between each head.

While the drums are not tuned to relative or exact or tempered intervals, as a guitar or a piano is tuned, they are most often heard as 2nds, $3 \mathrm{rds}$, and 6 ths in relation to one another or to the primary iyá, or mother drum. The drummers I have interviewed have all agreed that even though Cuban ethnologist Fernando Ortiz and the batá masters of the 1950s explained the tuning of the drums in solfeggio terms, or in "Western" music-oriented terms, they did so for better understanding within a lay public. Most drummers say this is not the way of tuning in common practice today. Rather, they look for the "ring," for overtones of each drum head, and, most important, for a separation of pitches 
or tones among all heads, that is, for six heads to have six different tones or usually four to six pitches (some may be doubled at the octave). When they strike or manipulate the drums with their fingers instead of their hands (called a "muff"), the drum pitch moves up a half step; so the three-drum orchestra could potentially have twelve pitches as its basic tonal repertoire.

The mathematics of the drums (or of the twelve pitches) is ultimately the rhythms themselves. Even within one rhythm, like that of the güiros or chekeres (gourds) that play a single rhythm repeatedly for hours in a ceremony, the sounded variation of syncopated patterns is a nonrandom series of fractions. At some point in the history of the rhythms, the language of sacred orichas, liturgy emerged in the form of a specific regulated pattern for each drum. Through the marriage of the three rhythmic patterns within a drum orchestra, a consequent rhythmic core was created. Thereafter, the sequence of several successive core or fundamental rhythms, or a sequence of trataos, was established and retained. ${ }^{17}$

Music and rhythmic organization are a synthesis of sounded time, patterned fractions in mathematical, as well as tonal, relationships. A drum liturgy or a specific religious drum tradition is an order or a long series of specific rhythms, or trataos. Buried in the resultant music that is heard are not only musical but also numerical intervals, patterned fractions that make up the combined rhythms. Rhythmically timed relationships are fundamental to African descended drum liturgies, and they affect human response behavior in specific predetermined (spiritual) ways.

Each tratao has the potential tonal and rhythmic substance to initiate spirit, to move the dancing, believing, or prepared body. Much of ritual drumming assumes, but also attempts to initiate, a progression of emotive as well as rhythmic patterns. Ritual singing is in synchrony with specific rhythms that are effected into sound, repeated, and intensified (sometimes exactly in synchrony and sometimes "floating above" the resultant rhythms). As ritual singing intensifies rhythmically and tonally, as the drumming is augmented in terms of speed and intensity as well, and as rhythmic dancing is repeatedly performed in unison, the human body is sensitized, affected, pulled into communion with a community of knowing bodies and with altered consciousness.

When there is an indication that a dancer's movements have intensified such that the body is "open" within the style of the dance, is "ready" for or "on the edge" of manifesting divine spirit, ritual drummers support the worshiping dancer's energy. Sometimes they simply play steadily, and that firmness gives rise to the shift between the material and spiritual worlds, the divine moment of transition or "crossover." At other times, drummers give insistent slaps, 
kassées or "breaks," to push for change or transformation. Still at other times, drummers make "differences": they play a completely different rhythm; or they play faster, louder, more forcefully; or they use "muffs" and insert rhythmic and tonal changes-all to generate the proximity of the spirit world, all to effect an opening of the delicate but necessary gateway into the spirit world.

When the dancing body is readied - that is, when the dancing body has penetrated the sacred gateway - the central core of the trunk is either extended with the extremities spread apart or contracted and vibrating rapidly and erratically. Often the worshiping priest/medium/performer hops on one foot, then arches the back and exposes the entire body. Within the characteristic dance patterns for each divinity, there is a climax or augmented motion; a fullbodied display results, sometimes in sustained energy, as in a slow and complete body undulation (e.g., in the feint of yenvalu), and sometimes percussively, as in the preparation for a rapid strike or at an implosion of energy (e.g., in the broad steps of Chango or the swift and erratic shifts of Yansan). ${ }^{18}$

Musicians in Fon, Yoruba, and other African ethnic groups of the past came to understand that specific codified intervals, sounded as drummed rhythms in a series, were able to produce physical, emotional, and spiritual transformations inside the believing and prepared body. Later, musicians in Haitian, Cuban, and Brazilian ritual communities replicated the rhythmic remembrances, the rhythmic series for affect in the bodies of dancing worshipers. The repeated "sequencing" of specific rhythmic patterns that are made up of sounded codified intervals and series of fractions corresponded to emotional changes in the dancing body, that is, other states of consciousness in the worshiping body. Over time, musicians savored the formulas of musical mathematics as traditional rhythms for each divinity of each African nation. They exclusively rendered the rhythmic drum sequences on ritual occasions. Without verbal articulation of the numerical expressions, intervals, or mathematics that underlies each rhythmic pattern and comprises each drum tradition, musicians have played a "buried" or "recessed" mathematics for centuries.

Today, master drum musicians understand this type of mathematical knowledge as musical knowledge, but they express it as "love of the ancestors" in rhythmic remembrances. They share with their apprentices the sequenced sacred rhythms that constitute what the analyses here refer to as "hidden mathematics." The ritual community is grateful for the layering of properly timed musical relationships because proper musical mathematics helps to accomplish ritual objectives, that is, spiritual transformations and balance between the human and spiritual worlds. In predetermined rhythmic, tonal, and intervallic re- 
lationships (or "variable," "shifting," and "acceptable" musical relationships), ritual musicians display the "buried mathematics" of the dance/music liturgy. In order to facilitate human dancing and suprahuman transformation, they rely on rhythmic remembrances. ${ }^{19}$

\section{Dancing}

Within the religions of Vodou, Cuban Yoruba, and Candomblé, the human body is mapped by the divinities themselves, and the specialized tissue of a given part of the body, with its associated internal organs, is understood in terms of its anatomical, associated physiological, and emotional functions. Consequently, anatomy, physiology, and psychology are linked within the danced rhythms of African-descended religious rituals. For example, in Haitian Vodou, a particular part of the body is associated with each of the Haitian divinities, or lwas. Dancer, researcher, and one of my teachers, Madame Lavinia Williams Yarborough stated that in teaching Vodou dances,

The feet are dedicated to the god of war, Ogoun Feraille; the hips to the Congo's spirits of beauty and love; the chest to the brave warriors, the Ogouns [and Ibo spirits, 1970: personal communication]; the spine to the snake god, the water god and the rainbow goddess, Papa Damballah, Maitre Agwe, and Maitress Ayida Wedo respectively. The hands are dedicated to the spider spirit, Ghede Zarien. $^{20}$

From Yarborough's description and from discussions with other dancing worshipers and ritual specialists, I constructed the accompanying chart for my three ritual sites. ${ }^{21}$ Most of the African nations that were on the island of Haiti at the outset of the Revolution in 1791 are displayed in terms of lwas on specific parts of the human body. In the Cuban context, the mapping of the body with Yoruba orichas is slightly different from Brazilian Candomblé orixás, even though these two are both Yoruba belief systems in the Americas. This difference helps to remember and emphasize that there is tremendous variation within the African practices of the Americas.

My dance consultants have cautioned me to make clear that the dances for the lwas, orichas, or orixás utilize the dancing body as a whole and that performers are concentrated fully within their entire bodies as they perform in routine ceremonies for and with the ritual community. Within the dances for each divinity, however, the divinity-associated body parts are usually empha- 
sized. For example, in the yenvalu dance of Haiti, the constant whole body undulation (in the torso, in the rippling of the back and the lift and fall of the chest) emphasizes the stories and importance of the snake, called "Papa Dambala." In Haiti, the snake is coded with notions of ongoing life. Two snakes together, Dambala and his wife, Aida Wèydo, make an alliance and, in an arch, cover and protect the Vodou world. Their typical undulating movements reference continuity of life, copulation, birth, and rebirth. Continuous life is thereby codified in the yenvalu dance through the visual undulation of the torso and back, and yenvalu coincides with the specific Haitian lwas that are mapped on the spine.

Yoruba dances also articulate the associated body parts of each divinity, mainly in hand and arm gestures and/or foot patterns, despite the entire dancing body's involvement. In Cuba, Ochun is sparkling, bubbling, silky-strong water. She splashes over the whole body and, in her womankind essence, spreads water or honey over the entire body with her arms and hands. Her body stroking links her to all the blood vessels throughout the body, but she emphasizes her lower abdomen and the genital area to invoke her power in fertility and reproduction or childbearing. In Brazil, Yansan's hands and arms-waving in the air, beating the air as if in a storm-characterize the orixá as air, breath, the wind. Yansan's dance uses alternating rib and hip shifts over a fast-paced foot pattern, activating the body areas with which she is identified. Accompanying chants, stories, and life histories of the divinities also reveal their associated body parts. Similar anatomical associations lead to physiological understandings when coupled with associated medicinal plants, all of which combine within spiritual knowledge.

African-descended dance/music rituals are carefully constructed sets of rhythmic and sensory stimulation that result in specific emotional and associated physical behaviors. While the ritual practices unfold religious liturgies and sacred orders of chants, drumming, and dancing, the rituals also compound and layer physiological principles of the body, which result in ecstatic psychological experiences, both conscious and unconscious. ${ }^{22}$ Concentration on specific parts of the body implies knowledge about what occurs inside the human body within repetitious, codified and mostly unison dance behavior. Rhythmic dance sequences are structured events that have been calculated over time to reach the full range of any one body's physiological and psychological capacities. With multiple bodies in strong, unison and repeated movement, however, the rhythms stimulate affect tremendously. What results from the 
rhythmic remembrances of dance performance is suprahuman performance that displays embodied physiology and psychology.

\section{CONCLUSION}

For over five hundred years of enslavement, colonization, and postcolonial dominion of the Americas, there have been periods when the drums were outlawed and ritual paraphernalia were destroyed. Prejudice and repression against African-descended religious practices have been rampant; however, the ritual systems, the dancing religions, have continued in Haiti, Cuba, and Brazil. The dancing and music-making body has held forth, repeatedly enunciating Fon, Yoruba, Kongo-Angola, and other African understandings and displaying embodied rhythmic responses. African descendants in the Americas have consistently joined together in ritual practice to articulate the resultant rhythms and the ensemble unison dancing of their heritages; that is, worshiping musicians and dancers did remember. Unison dance expression of codified rhythmic patterns have constituted not only their religious faith but also their faith in the power of the dancing and music-making body, called aché in Cuba, axe in Brazil, and espri in Haiti.

In rhythmic rituals, the dancing/music-making worshiper was able to reinforce memory and enable, as well as retain, the embodiment of all sorts of knowledgeS-over centuries and across geographies. Embodied philosophy continues to frame the values and behavior of worshipers and reveals an understanding of a suprahuman and interactive world within ritual performance. Embodied botany continues to emerge from within sacred chant texts that have survived in the vocal repertoire and healed the bodies of worshiping African descendants. Embodied physiology continues to surface within the particular parts of the human body that are associated with spiritual divinities and also from within the totality of dance/music performance. Embodied psychology continues to unfold in efficacious transformations, supported and/or initiated by codified, rhythmic drum and dance sequences. Embodied mathematical knowledge ultimately directs drum orchestrations, excites choral singing, and instigates powerful unison ensemble dance movement, in order that worshipers experience and store knowledge bodily.

The accumulation of knowledge in ritual practice and the transposition and application of that knowledge to social life yield the wisdom within the dancing religions or embodied knowledgeS. Rhythmic rituals have guarded 
those knowledgeS, and those of us who dance and make music store them as rhythmic remembrances, only to share the resulting wisdom repeatedly in ritual performances. There have always been rhythms, for centuries-rhythms inside the drums and within the dancing body-and rituals continue the rhythms. There are also memories, images that surface from within the rhythms inside the rituals. The memories echo infinitely across time and geography. They send bodily messages, rhythmic remembrances. Dance rhythms, rituals, and remembrances leave us transformed, centered, balanced, fresh, and full. We in the ritual community dance the ancient body knowledgeS, the wisdom of aché, axe, and espri.

Al final de bailar, cantar o tocar, tenemos que reasumir a Elegba Para llamar a sus dimensiones de Ena y Echu, las cerradas.

La dualidad inmensa de esta fuerza vital nos deja organizados, en orden, completos y satisfechos a final del túnel espiritual.

Nos dejan rezando.

Nos dejan transformados.

La sabiduría siempre nos deja bailando.

[When we finish dancing, singing, and drumming, we must return to Elegba in his closing forms of Ena and Echu. The immense duality of his vital force leaves us clear, centered, completely satisfied at the end of a spiritual path.

The two sides of Ena leave us praying, transformed.

Wisdom always leaves us dancing.]

\section{Notes}

This essay is taken in large measure from my book Dancing Wisdom, which was condensed for a keynote address at the Atlantic Initiative Conference, University of Michigan, Ann Arbor, March 17, 2005. What follows is a more concentrated inquiry on rhythm. It is dedicated respectfully to the following musicians who have assisted my classrooms, my research, and my ritual life: drummers Gerald (Mamadi) Victory, Rick Blanton, the late Wilfredo (Fredi) Moreno, Victor (Papo) Sterling, Abi Holiday, Nelson Lebron, Michael Wingfield, Hiram Rivera, Nestor Citron, Butch Haynes, Tobagi Stewart, Ralph Eaglefeather, Sheila Escovedo, Pete Escovedo, Juan Escovedo, Dobru, Jessie, Edner, Fanfan, and Richard Doest, as well as pianist Julius Robinson-my fantastic friends and musical support.

1. There is always a measure of variation within "unison"; it is the intent of unison movement that differentiates it from genuine variation. Here, the term unison movement 
presumes the variation that always exists among performances of the same dance material, either in repeated performance of any one individual or among the performances of several or many performers intending to execute the same dance motions, activities, or behaviors.

2. The communities I draw my examples from can be seen in my videos: Public Vodun Ceremonies of Haiti and in the Palo section of Cuban Dance Examples. These show ensemble ritual dancing, which can be compared with solo performances in Cuban Dance Examples.

3. Daniel, Dancing Wisdom, 51-93.

4. Ibid., 148-62; Bolívar, Los orichas de Cuba; Desmangles, Faces of the Gods; Brandon, Santería from Africa to the New World; Harding, Refuge in Thunder. The authors of religious texts that are referenced within the present essay owe tremendous debt to the courageous undertakings of earlier investigators of African religious practices in the Americas: see, for example, Herskovits, Life in a Haitian Valley; Hurston, Tell My Horse; Courlander, Haiti Singing; Landes, City of Women; Bascom, "Focus of Cuban Santería," Ifa Divination, Shango in the New World, and Sixteen Cowries; Deren, Divine Horsemen; Cabrera, El monte, La sociedad secreta abakuá, Yemaya y Ochun, and Reglas de congo; Verger, Notes sur le culte des Orisa; Métraux, Voodoo in Haiti; Jahn, Muntu; Bastide, African Religions of Brazil; Dunham, Island Possessed.

5. Excellent examples of the psychological and physiological connection of dance affect can be viewed within the following films and tapes: Deren, Divine Horsemen (1967); Kramer, To Serve the Gods; Brewer, Bahia; Gonzalez Martin and Gallardo, Ache Moyuba Orisha; Quinones and Soto, Nganga Kiyangala; Vega, When the Spirits Dance Mambo.

6. Thornton, Africa and Africans, 129-334; Knight, Caribbean, 23-66.

7. Sweet, Recreating Africa, 13-86.

8. Ibid., 30. The trafficking in Africans ended slowly over a century in the sites of study-officially in 1804 (1791) for Haiti, in 1886 for Cuba, and in 1888 for Brazil.

9. See, respectively, Willocks, Umbilical Cord, 47-98; Saiton et al., Histoire et Civilisation; Williams, From Columbus to Castro, 136-55; Hartog, Curaçao, 159-9o.

10. For example, many songs and chants in both Cuban Palo and Brazilian Angola rituals are in Spanish or Portuguese, due in part to the early introduction and continuous assimilation of "Angola" or Kongo-Angola peoples to the languages of the colonizers from the sixteenth century forward. By the nineteenth century, the linguistic repertoires of these African-derived groups were diminished, and the languages of the dominant masters were often substituted in songs and chants-sometimes with just a few words or phrases, but at other times, they were fully transposed.

11. See, for example, Mason, Orin Orisa; Laguerre, Voodoo Heritage; Courlander, Haiti Singing and Drum and the Hoe.

12. Laguerre, Voodoo Heritage; Courlander, Haiti Singing and Drum and the Hoe; Verger, Ewé; Voeks, Sacred Leaves of Candomblé; Cabrera, El monte; Marks, "Exploring El monte."

13. Marks, "Exploring El monte," 229.

14. Mason, Orin Orisa.

15. Bloch, "Symbols, Song, Dance," 51-81. 
16. I am especially grateful for discussions I had during February, March, and April of 2008 with three knowledgeable batá drummers in the San Francisco/Oakland Bay area: Dr. Umi Vaughan, Rick Ananda, and Sandi Perez. What I posit here is heavily impacted by their views; however, whatever faults may be found in my argument are entirely mine. My consultants shared with me immeasurable insights to the path of those dedicated to the drums; some of their more descriptive words appear in quotes. I thank them here publicly.

17. Among Cuban professional dance specialists, the rhythm of the güiros or chekeres is most often called iyesa, and so is the dance step that accompanies that rhythm. These terms are not to be confused with the Iyesa drums, which are single-headed, more conical than barrel or hour-glass shaped, and used mainly in separate celebrations for Ochun. The Iyesa drums have a different set of rhythms than those used by güiros or chekeres.

18. The terms used in examples here refer to specific dance practices, dance names, and the divinities who are associated with each dance.

19. See also Fleurant, Dancing Spirits; Amira and Cornelius, Music of Santería; Klein, Yorùbá Bàtá Goes Global; Summers et al., Bata Rhythms from Matanzas.

20. Yarborough, "Dunham Technique," 159.

21. The chart is a skeletal account of what was generally accepted between 1990 and 2002. I am grateful to Haitian dance masters Jean Léon Destiné and Louinés Louinis; Brazilian dance specialists Pai Carlinhos, Augusto Soledade, and Isaura Oliveira; and Cuban dance specialists Ana Perez and Lourdes Tamayo. See also the computer drawings by Leah Smith of the human body and the spiritual divinities of Haiti, Cuba, and Brazil in Daniel, Dancing Wisdom, 62-63, 75-76.

22. Walker, Ceremonial Spirit Possession; Bourguignon, Trance Dance; Deren, Divine Horsemen.

\section{Bibliography}

Amira, John, and Stephen Cornelius. The Music of Santería; Traditional Rhythms of the Batá. Crown Point, IN: West Cliffs Media, 1992.

Bascom, William. “The Focus of Cuban Santeria." Southwest Journal of Anthropology 6, no. 1 (Spring 1950): 64-68.

Bascom, William. Ifa Divination: Communication between Gods and Men in West Africa. Bloomington: Indiana University Press, 1969.

Bascom, William. Shango in the New World. Austin: African and Afro-American Research Institute, University of Texas, 1972.

Bascom, William. Sixteen Cowries: Yoruba Divination from Africa to the New World. Bloomington: Indiana University Press, 1980.

Bastide, Roger. The African Religions of Brazil. 1960. Baltimore: Johns Hopkins University Press, 1978.

Bloch, Maurice. "Symbols, Song, Dance, and Features of Articulation: Is Religion an Extreme Form of Traditional Authority?" Archives Europénnes de Sociologie 15 (1974): $52-81$. 
Bolívar, Natalia. Los orichas de Cuba. Havana: Ediciones Union, 1990.

Bourguignon, Erica. Trance Dance. New York: Dance Perspectives Foundation, 1968.

Brandon, George. Santería from Africa to the New World: The Dead Sell Memories. Bloomington: Indiana University Press, 1993.

Brewer, Giovanni. Bahia: Africa in the Americas. Boston: Broadcast Video Productions, 1988. Video recording.

Cabrera, Lydia. El monte. 1954. Miami: Colección del Chichereku, 1983.

Cabrera, Lydia. Reglas de congo, Palo Monte Mayombe. 1979. Miami: Ediciones Universal, 1986.

Cabrera, Lydia. La sociedad secreta abakuá. 1958. Miami: Ediciones C.R., 1970.

Cabrera, Lydia. Yemaya y Ochun. New York: Colección del Chichereku, 1974.

Courlander, Harold. The Drum and the Hoe. Berkeley: University of California Press, 1973.

Courlander, Harold. Haiti Singing. Chapel Hill: University of North Carolina Press, 1939.

Daniel, Yvonne. Cuban Dance Examples: A Glimpse of Cuba through Dance. New York: Insight Media, 1992. DVD/video recording.

Daniel, Yvonne. Dancing Wisdom: Embodied Knowledge in Haitian Vodou, Cuban Yoruba, and Bahian Candomblé. Champaign: University of Illinois Press, 2005.

Daniel, Yvonne. Public Vodun Ceremonies in Haiti. Filmed, produced and directed by Y. Daniel, New York: Insight Media, 1997. DVD/video recording.

Deren, Maya. Divine Horsemen: The Living Gods of Haiti. 1953. Reprint, New Paltz, NY: McPherson, 1983.

Deren, Maya. Divine Horsemen: The Living Gods of Haiti. 1967. New York: Mystic Fire Video, 1985. Video recording.

Desmangles, Leslie. Faces of the Gods. Chapel Hill: University of North Carolina Press, 1991.

Dunham, Katherine. Island Possessed. Garden City, NY: Doubleday, 1969.

Fleurant, Gerdès. Dancing Spirits: Rhythms and Rituals of Haitian Vodun, the Rada Rite. Westport, CT: Greenwood Press, 1996.

Gonzalez Martin, Antonio, and Christina Gallardo. Ache Moyuba Orisha. New York: Latin American Video Archives, 1990. Video recording.

Harding, Rachel. A Refuge in Thunder: Candomblé and Alternative Spaces of Blackness. Bloomington: Indiana University Press, 2000.

Hartog, Johan. Curaçao: From Colonial Dependence to Autonomy. Aruba: De Wit, 1968.

Herskovits, Melville. Life in a Haitian Valley. 1937. Reprint, New York: Octagon Books, 1975.

Hurston, Zora Neale. Tell My Horse. Philadelphia: J. B. Lippincott, 1938.

Jahn, Janheinz. Muntu: The New African Culture. Translated by Marjorie Grene. New York: Grove Press, 1961.

Klein, Debra. Yorùbá Bàtá Goes Global: Artists, Culture Brokers, and Fans. Chicago: University of Chicago Press, 2007.

Knight, Franklin. The Caribbean: The Genesis of a Fragmented Nationalism. 2nd ed. New York: Oxford University Press, 1990.

Kramer, Karen. To Serve the Gods. New York: Erzulie Films, 1981. Motion picture. 
Laguerre, Michel. Voodoo Heritage. Beverly Hills, CA: Sage Publications, 1980.

Landes, Ruth. City of Women. 1947. Albuquerque: University of New Mexico Press, 1994.

Marks, Morton. "Exploring El monte: Ethnobotany and the Afro-Cuban Science of the Concrete." In En Torno a Lydia Cabrera, edited by Isabel Castellano and Josefina Inclán, 227-45. Miami: Universal, 1987.

Mason, John. Orin Orisa: Songs for Selected Heads. Brooklyn: Yoruba Theological Archministry, 1992.

Métraux, Alfred. Voodoo in Haiti. Translated by Hugo Charteris. New York: Knopf, 1972.

Quinones, Tata, and Louis Soto. Nganga Kiyangala. New York: Latin American Video Archives, 1991. Video recording.

Saiton, Jean-Pierre, Raymond Boutin, Richard Chateau-Degat, Lydie Ho-Fong-Choy Choucoutou, and Gerges B. Mauvois. Histoire et Civilisation de la Caraïbe (Guadeloupe, Martinique, Petites Antilles). Tome 1: Le temps des Genèses; des origines á 1685. Paris: Maisonneuve and Larose, 2004.

Summers, Bill, Michael Spiro, Duraldo Devar, and Vanessa Lindu. Bata Rhythms from Matanzas. San Francisco: Cabiosile, 2007.

Sweet, James H. Recreating Africa: Culture, Kinship, and Religion in the African-Portuguese World, 1441-1770. Chapel Hill: University of North Carolina Press, 2003.

Thornton, John. Africa and Africans in the Making of the Atlantic World, 1400-1800. New York: Cambridge University Press, 1998.

Vega, Marta Moreno, and Bobby Shepard. Cuando los Espiritus Bailan Mambo/When the Spirits Dance Mambo. New York: Franklin H. Williams Caribbean Cultural Center/African Diaspora Institute of New York City, 2002. Film.

Verger, Pierre Fatumbi. Ewé: O uso das plantas na sociedade iorubá. Sao Paulo: Editora Scharcz, 1995.

Verger, Pierre Fatumbi. Notes sur le culte des Orisa et Vodun á Bahia. Dakar: IFAN, 1957.

Voeks, Robert A. Sacred Leaves of Candomblé: African Magic, Medicine, and Religion in Brazil. Austin: University of Texas Press, 1997.

Walker, Sheila. Ceremonial Spirit Possession in Africa and Afro-America. Leiden, Holland: E. J. Brill, 1972.

Williams, Eric. From Columbus to Castro: The History of the Caribbean. 1970. New York: Vintage Books, 1984.

Willocks, Harold W. L. The Umbilical Cord: History of the U.S. Virgin Islands from the Pre-Columbian Era to the Present. Christiansted, St. Croix: H. Willocks, 1995.

Yarborough, Lavinia Williams. “Dunham Technique.” In Katherine Dunham: Reflections on the Social and Political Contexts of Afro-American Dance, edited by Joyce Aschenbrenner, 121-59. New York: Congress on Research in Dance, 1980. 


\title{
Citizenship and Dance in Urban Brazil: Grupo Corpo, a Case Study
}

\author{
LUCÍA M. SUÁREZ
}

\section{INTRODUCTION}

Arguably, civil society in certain countries of Latin America and the Caribbean is in a state of ruin. Perhaps because of that, the conceptualization of citizenship has become a critical point of interrogation. Arjun Appadurai and James Holston posit,

Citizenship concerns more than rights to participate in politics. It also includes other kinds of rights in the public sphere, namely civil, socioeconomic, and cultural ... It concerns the moral and performative dimensions of membership that define the meanings and practices of belonging in society. Undeniably, people use violence to make claims about all of these dimensions of belonging. ${ }^{1}$

In a country as large and complex as Brazil, formulations of and access to belonging are beleaguered by historical exclusions and economic disparity. Violence gives the disenfranchised a certain kind of voice- "insurgent citizenship," as Holston calls it in his recent book. Yet I am not convinced that insurgency leads to functional democracy; instead, it makes the democratic project ever more fragile. With these considerations of exclusion and insurgency, I look to the interstitial spaces that allow for claims to belonging, as suggested in the preceding quotation. In my research, I explore modalities of resistance and survival and new formulations of citizenship and/or pathways to social inclusion by focusing on dance companies, their development, their international success, and their eventual role as local sociocultural agents. ${ }^{2}$ 
Lately, I have found the theoretical formulations presented by Argentineborn Mexican cultural theorist Néstor García Canclini of great interest. He proposes a fundamental relationship between consumer markets and citizenship, arguing that to think about different kinds of market-driven consumption could lead to new theories of social renewal.

The articulation of consumption and citizenship requires a relocation of the market within society, the imaginative re-conquest of public spaces, and interest in the public. Consumption can be a site of cognitive value; it can be good for thinking and acting in a meaningful way that renews social life. ${ }^{3}$

How can social life be renewed by consumerism? In many ways, dance arts internationally marketed as signifiers of a national identity have been engaging this phenomena for quite some time. Dance, from my perspective, is clearly an object of consumption, valued highly on a global scale, capable of becoming an active agent in local and specific situations. Still, such a vast statement begs definition, elaboration, and qualification. Thus, I find myself caught up in the examination of the multiple, often seemingly unrelated narrative constellations produced by dance, choreography, and representations of violence.

With this essay, I point to contact zones between Brazilian cultural production and local sociocultural realities through specific examples of dance and film and argue that they define interpretations of Brazilian national identity and make important interventions to what is arguably a fragile democracy. ${ }^{4}$ In particular, I suggest that the creative trajectory of the internationally renown modern dance company Grupo Corpo and their grassroots project Corpo Cidadão (an NGO founded in 1999) serve as locations of action that intercept the harsh realities of extreme marginalization, poverty, and violence in Brazil. Arguably, as we will see, Grupo Corpo's work and artistic experience have functioned as a social catalyst that has recuperated national memory through the group's staged performance of Maria Maria (1976) and that is presently serving the city through Corpo Cidadão.

In the following pages, I draw out five sections through which I show how an elite stage choreography can represent a nation and the specific hybrid nature of its people; how a dance company, even despite itself, is symbiotically influenced by the city it occupies and the artistic movements that precede it; how a group performing a nonnarrative choreography tells a story of alienation and ritual spectacle anyway; and how the fame acquired by many years of international and national success put Grupo Corpo in a position to return to the city and its problems. In the course of the last four decades, Brazilian national 
representation has changed quite dramatically. In 1976, Grupo Corpo hit the world stage as a uniquely Brazilian phenomenon; today, ghetto movies have hit international screens as representative of an equally Brazilian condition. Both dance and film representations signal the impasses Brazil continues to experience as the nation shapes a much desired democracy and includes new citizens. I suppose that a succinct way to delineate my inquiry would be to ask, how do highbrow and lowbrow art forms intersect to create a crucial space of contact and possibility? Specifically, how does a dance company help redefine a nation, represent artistic growth, intervene violence, and interpolate citizenship?

\section{MODERNITY AND THE CITY}

In the 1920s, the anthropophagy movement in Brazil addressed the issue of Brazilian modernity, describing Brazilian uniqueness and calling for aesthetic and economic progress that would allow the country to stand on equal terms with developed nations. In particular, Oswald de Andrade forged an imaginary national identity through his exegesis of the Manifesto antropófago. His text states, "Anthropophagy alone unites us ... Socially. Economically. Philosophically ... sole law of the world ... My sole interest is in that which is not mine. Law of humankind." 5 The basic premise of the discourse of anthropophagy was that Brazil was able to ingest all that was foreign and give it a special twist, thus transforming colonial and imposed European ideology and philosophy into a uniquely Brazilian phenomenon. Andrade's anthropophagy inverted the negative representations cultivated in the sixteenth century that portrayed Brazilians as "natives who collected Brazil-wood for trading with Europeans, or by those who collected Europeans in order to devour them in complex anthro-

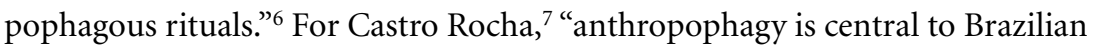
culture and has been present in three fundamental stages of Brazil's intellectual history, namely, in Romanticism, Modernism, and Tropicalism." ${ }^{8}$ For me, anthropophagy is ever present, particularly, in dance and performance.

In the 1950s, modernist architecture had a key moment of success with the construction of Brasilia. However, in a larger sense, successful modernism, where perpetual renovation is financially possible, has been constantly foreclosed by dictatorships, military regimes, and general government corruption. In the popular imaginary, Brazil is relegated to the status of a tourist country: the site of samba, sex tourism, exotic pleasures, and daring ecological travel. Brazilians have looked up to Europe and the United States, adopted their most attractive ideologies and patterns, and changed these to fit the particularities of Brazil's national circumstances. Because of Brazil's history as a colonized and 
postcolonial space, nothing seems to be new but, rather, an imitation, repetition, or translation. Critics such as Brazilian Wander Melo Miranda have described this phenomenon in terms of a late modernity in Brazil.

Brazil's late modernity engages novelty and celebration in both its accomplished feats and setbacks. The modernist project is, as Jurgen Habermas has insisted, an unfinished one. For this reason, I propose that, rather than looking with sadness at the cities that stand alone in the middle of the Sertão or amid the glaring poverty in the neighboring favelas as they struggle to rise to an unattainable greatness of modern symbolism with their short cycles of evolution, we should view and evaluate all of the attempts toward modernization with pride. I suggest that the project of modernity in Brazil is one of audacity and energy. It is an ever-new adventure that responds to the huge impediments imposed by national economic failures and the disintegration of sociopolitical stability.

Social critics have insisted that Belo Horizonte, the fourth largest city in Brazil, is a haven of the cruel contradictions of modernization in an economically and politically challenged country. For example, in the introduction of Arquitetura da modernidade, Brazilian critic Leonardo Barci Castriota quotes Claude Lévi Strauss's observations from a visit in the 1930 published in Tristes Tropiques. Lévi Strauss wrote that the cities of the New World suffer from a sense of "decadence." As soon as they are completed, these cities are immediately in need of reconstruction. The neighborhoods resemble a fair or an international exhibit constructed to last for a few months, rather than an urban space that would be a lasting symbol of the cities' modern status. With the lapse of time, the celebration ends, and the cities fall apart. Lévi Strauss concludes that they are not new cities as contrasted with ancient cities; instead, they are cities with a very short cycle of evolution. Barci Castriota agrees with Lévi Strauss's observations of the developing Americas and discusses how it applies to Belo Horizonte, where the city barely manages to establish itself before being engulfed by what he refers to as the destructive logic of modernization. ${ }^{9}$ The city attempts to become modern, both economically and aesthetically, but these attempts are precluded by lacking economic resources. ${ }^{10}$ Continual renovation and renewal is not possible. Consequently, urban decay becomes an integral part of the city. Theoretically, then, the central focus extends beyond any tradition of ruptures and continuities. Thus, understanding the city requires accepting the layers of ruin that result from failed attempts of modernization. As such, the city is organic. It is in constant transition, always responding to the relentless elements. Like most major cities in Latin America, Belo Horizonte ex- 
ists in a constant state of transitoriness. Its attempts at modernization are ceaselessly plagued by the reality of social and economic ruin, which is overtly visible in the streets-through homelessness and crumbling buildings. In his seminal works, Walter Benjamin has described that history is presented in transitory nature: "the process of natural decay marks the survival of past history within the present." 11

I would like to avail myself of these concepts of city in a state of ruin and of ruin as a natural state of transitoriness to entertain my own musings about the ways in which dancing bodies expose potential in space and thus intersect the city. If transitoriness is a viable state through which the ruins of sociopolitical failures can be challenged, then perhaps the human body and its movement in space offer a site of contestation. Perhaps bodies, albeit physical, real, and materially present, can be compared to the city, as they are never static. From birth, they are en route to death, through experiences of flourishing and inevitable decay. Bodies in space, in perpetual movement, defy decay. Unlike the citieswhich have proven to fail at the modernizing project—bodies engaged in a long legacy of dance traditions defy annihilation and historical erasure. Arguably, dance memory performed by dancers, both in the streets and on the stage, keep alive multiple and multiplying rhythms, steps, choreography, languages, and gods and challenge class, gender, and racial categories.

Art, dance, music, and community projects are active interveners against human and moral ruin through discipline and memory. They offer models of survival for individuals, communities, histories, and traditions. The arts challenge the state of aesthetic, economic, and social decay that so afflicts cities like Belo Horizonte. In this light, the arts are vital to processes of democratization. However, the process is convoluted and often not so simple to trace. In the following sections, I hope to support this affirmation by drawing out the more complex sociocultural interactions existent between a history of aesthetic modernity, elite choreography, African dance traditions, and market representations of violence through film. How do all of these signifiers of Brazilian reality intersect to present a larger narrative of rights, citizenship, and violence? How does dance play a pivotal role to counter the negative realities of poverty?

\section{GRUPO CORPO-THE BEGINNING: REPRESENTING THE COMPLEXITY OF THE BRAZILIAN NATION}

Grupo Corpo Companhia de Dança was founded as a cooperative dance company in 1975, during the last ten years of the Brazilian military regime. The 
troupe was established by a group of siblings and a close friend: Rodrigo Pederneiras (company director and choreographer), Pedro Pederneiras (stage manager), Paulo Pederneiras (lighting manager), and Miriam Pederneiras and Carmen Purri (dancers and ballet mistresses). Initially, they met in the basement of the Pederneiras family house, where they held rehearsals and eventually opened a school. They studied with the pioneers of dance who came from Europe in the 1960s, such as Rolfo Gelewsky, Klauss Vianna, and the Brazilians Carlos Leite and Marilene Martins. They also studied in Buenos Aires, where the dance world was more firmly established. Over the course of almost forty years, Grupo Corpo has performed over thirty new choreographies. The company's technical style integrates ballet, modern dance, and African movements and rhythms. This synchretic style underscores the company members' dance education and mirrors Brazil's complex sociocultural history. For example, the company's creative evolution can be subsumed under three key phases that reflect some of the changes the country has experienced. The first phase of the company's development (1975-80) is shaped by the recuperation of a multiple past and the affirmation of the present, leading to a much-needed sense of hope and future possibility. ${ }^{12}$

Among the first performances were Maria Maria (1976) and Último Trem (1980), which were created by the Argentine Oscar Araiz. While it might seem odd that an Argentine choreographer would be the one to stage a piece that is identified as representative of Brazilian culture, it was quite logical. He had been invited to set it, since years earlier, Rodrigo and Pedro Pederneiras went to study with him in Buenos Aires and had then developed a very close working relationship. Araiz became a teacher and mentor for the troupe, helping them realize their initial goal of organizing as a professional dance company. The piece is ultimately symbolic of a Brazilian national unity, but it also engages a universal story of survival against all odds. It was met with extreme success in Argentina, where they performed it annually in response to enthusiastic invitations. Recalling Benedict Anderson and Paul Gilroy, dance critic Randy Martin reminds us that "national states have only ever been composed of many distinct cultural groups and identities ... [that] are themselves projected, to both citizens and foreigners, as if they made some coherent whole, unity" (Critical Moves, 177). That unity is often cultivated and performed in relation to the specific circumstances of the artists. To a certain extent, it can be argued that Maria Maria is an exercise in self-exoticism that signals a more complicated situation. After my interviews with a number of the original company members, 
I believe that they were strategizing in order to enter an international scene of dance and national representation.

Maria Maria put the young troupe on the map of the international theater circuit. Importantly, Maria Maria served as an internationally marketed master narrative of a country that was foundationally shaped by African history and traditions. This kind of representation was novel for European audiences and deeply affirmative to the Brazilian masses, whose African roots had been until then historically negated and fairly absent in terms of national representation. With Maria Maria, Grupo Corpo becomes one of the first highbrow dance groups to introduce popular, African-based dance and tradition to the elite national and international stage. Set to music by Milton Nascimento and Fernando Brant, this performance also initiated a tradition of working with major Brazilian composers.

In the years that followed, Rodrigo Pederneiras became the sole choreographer, ${ }^{13}$ and the company eventually entered a second phase of production (1981-93), which visited the established "greats" of classical dance and music. The following list exposes a curious revisiting of European tradition: Rodrigo produced Sonata (1984) with music by Sergei Prokofiev, Prelúdios (1985) with music by Frédéric Chopin, Schumann Ballet (1988) with music by Robert Schumann, and Missa do Orfanato (1989) with music by Wolfgang Amadeus Mozart. ${ }^{14}$ In contrast to an original and nationally important work such as Maria Maria, this phase seems to negate the original, giving preference to imitation. However, literary critic Roberto Schwarz notes, "Copying is not a false problem, so long as we treat it pragmatically, from an aesthetic and political point of view freed from the mythical requirements of creation ex nihilo." 15 Thus, I suggest that this period of Grupo Corpo's artistic development is very Brazilian.

Arguably, Grupo Corpo's creative production finds its roots in the Brazilian tradition introduced by Oswald de Andrade (1809-1954) in his texts Manifesto da poesia Pau-Brasil (1924) and Manifesto antropófago (1928). Anthropophagy is that search for aesthetic excellence and a desire for a utopian state. Grupo Corpo engages this historical trajectory of Brazilian modernity and, consequently, highlights the interactivity between the African and folkloric influences that shape it. The company, in this second phase, is the quintessential antropófago (cannibal). It has ingested as much as it could of all classical and popular dance and performance forms and then added a unique and dynamic twist of its own. Any copying from European models actually informs 
the group's active exploration of national identity through the quagmire of inherited colonialism and global dance experiences.

In brief, during the second phase, the company was experimenting with classical dance language as it tried to discover its own place in the international dance circuit. Grupo Corpo also continued to figure out ways to return to uniquely Brazilian forms of expression. For example, Rodrigo choreographed to the works of famous national composers such as Ernesto Nazareth and Heitor Villa-Lobos and to contemporary vanguard Brazilian music such as Uakti. ${ }^{16}$ In 1979, the company traveled to Paris for a six-week engagement at the Theatre de Ville (formerly the Sarah Bernhardt Theatre), after which the young dancers were able to stay on for approximately six months and discover new trends in dance as well as improve their own techniques.

According to my timeline, in the third phase of the company's development (1994-present), Grupo Corpo has achieved a distinctive artistic maturity. With pieces like Sete ou oito peças para um ballet (1994) and Parabelo (1994), the staged works and the artists have become harbingers of a vanguard in movement that stretches beyond the limits of mere imitation of the classics. With the choreographies in this phase, Rodrigo Pederneiras legitimizes his company's originality. Now Grupo Corpo has integrated international dance language into choreography that is unique to and symbolic of Brazilian experience, without being trapped into any stereotype of Brazilian exoticization. Rodrigo is counted among the greatest choreographers of the twentieth century, along with such world-renowned creators as Merce Cunningham, Martha Graham, José Limón, and Pina Bausch. Within historical parameters, Grupo Corpo has functioned as a catalyst that has moved from the recuperation of Afro-Brazilian national history with Maria Maria (1976), to imitation with Schumann Ballet (1988), to the avant-garde with Sete ou oito peças para um ballet (1994), to reintegration into the city through its social project Corpo Cidadão (1999).

\section{MARIA MARIA: DANCE AS A MASTER NARRATIVE}

Maria Maria draws on a historical national identity shaped by slavery, violence, and censorship. It was first performed in the Palacio das Artes in Belo Horizonte in 1976. The piece tells the story of a heroine figure that metaphorically represents Brazil's multiple and multiplying histories and identities. The name Maria is extremely common throughout Latin America and Spain. The author of the text, Fernando Brant, claims that he fashioned this character according to his memory of two Marias: Maria Tres Filhos, a daughter of slaves who had wit- 
nessed his birth; and Maria Tatão, a contemporary of his who died at a young age. Nonetheless, he did not want to limit Maria Maria to the memory of these two women: "Maria Maria is more than a script of a woman following her destiny, [it is] something like the journey of a woman moving toward human solidarity." 17

Maria's character is performed by two or three different dancers, in order to highlight the multiple aspects of Brazilian life and womanhood. The text, composed of fifteen sections, narrates a lifeline from birth to death. The choreographed poem exposes the simplicity of a poor woman, the seminal role of colonialism, the resulting displacement and exploitation caused by the Middle Passage, and cultural/religious syncretism. The performance is a grand spectacle of a hybrid national identity and of suffering peoples surviving all odds. In the programs distributed at performances in Buenos Aires, the following description informed the public of this very Brazilian experience.

Maria Maria, a simple name of a woman. Black body with soft secrets, lively eyes sniffing the night, strong arms working the day ... A coming and going of cooks preparing delights for some grand feast. Among them: Maria. While they stir the kettles, they remember their ancestors ... The slaves recall their land of origin, their natural liberty ... Beaten and wounded, the memory of the gods they venerated in their land, the African gods, are always present in them ...., but in Brazil there are other gods that they did not know and whose influence they could not escape ... On her death-bed Maria tells her truths with profound sadness and a steely hope. Later, death, burial. All sing her song of death, her creed. ${ }^{18}$

Maria is one feminized nation composed of many experiences, races, and religions. The music and text are not about defeat but about triumph. Even as Maria goes to her grave, hers is a life that counts. As she recalls her life, the truths and sadness, she does not resign herself to dismay. This representation of human resilience also served as a metaphor of the country's overwhelming experience with a repressive military government.

This period of Latin American history was fraught with disappearances, torture, silencing, and general fear. The company's initial artistic production corresponded to a series of international, neighboring political conditions, such as the 1973 coup d'état that rendered Chile a military/dictatorial state under the leadership of General Pinochet and the continuing "dirty war" in Argentina under a repressive military regime that committed crimes of mass dis- 
appearances and murders. Brazil was experiencing its own extended period of military rule. The Argentine, Brazilian, and Chilean governments took violent, repressive action to eliminate all contamination and focused on-but were not restricted to- the communists. Such social conditions were volatile in many respects. Cultural elites created a climate of solidarity; they sought each other out and engaged intensively in artistic production as a response to the severe repression; thus, the presence of a number of Argentine artists in Brazil was no coincidence. They would escape their own dictatorships and live in obscure security in a neighboring country where their own revolutionary ideals were silenced, but not by violence (toward them). It was precisely because of this political climate that the Brazilian people needed a national narrative that would recover their past history and affirm their present lives.

Despite the economic hardships, military repression, racial incongruities, and general fear, the people never gave up. In 1975, while the military was "cleaning" the country of all undesirables, the fact remained that Brazil was not a homogenized nation and could never fulfill the dreams of fascist ideals of purity. Arguably, the military repression coalesced the vanguard movements throughout Latin America, and the innocent production of Maria Maria underlined this very dichotomy between a government that sought progress through intolerance and a country whose identity was shaped by its history of slavery, miscegenation, African traditions, and folklore. ${ }^{19}$ Maria Maria was a consequential response to this tension. Ultimately about Brazilian resilience, it is a master narrative that recognizes changes and rejoices in the continuities that arise from those very changes. This performance became an immediate success in Buenos Aires and Paris, and Grupo Corpo disclosed to the world the strength of the Brazilian people.

While Maria Maria was interpreted as a national narrative, it also played a pivotal role in locating Belo Horizonte on the map as a leading cultural city, alongside Rio de Janeiro and São Paulo. The dance piece relates specifically to Minas Gerais (the two Marias are from Diamantina, an important eighteenth century, colonial, gold-mining town). The musical score belonged to the Minas Gerais region on several levels. First, one section is composed of a poem by Mineiro ${ }^{20}$ writer Sérgio Sant-Anna, titled "I Am an Old Black Woman, Sitting Here in the Sun."21 Second and most important, the composition was exclusively performed by Milton Nascimiento and Nana Caími to Fernando Brant's lyrics. Nascimento and Brant were part of the group O Clube da Esquina, which included Lô and Marcío Borges, Ronaldo Bastos, Beto Guedes, Toninho Horta, and Carmelo Larrea. During the sixties and early seventies, they became 
a phenomenon of the people, especially of the Mineiros. They gathered on the street corner of Lô's house in Belo Horizonte and played for the kids of the neighborhood. The story goes that the group of friends would meet on a street corner in the working-class neighborhood of Sagrada Família. Their rehearsals on a street corner were highly symbolic. The group did not belong to any elite club; instead, it belonged to everyone, in a public space that was neither limited nor limiting. During repressive military times, bringing music into the streets resisted a sterile, official public sphere. Grupo da Esquina sang on corners and recorded major, international hits, reviving the local, popular memory of the peoples and becoming a national and international success story.

In an interview, Rodrigo Pederneiras emphasized the fact that Brazil is a colonial country shaped by mixed elements that are rooted in a certain kind of tension. He questioned how one could represent that and added that the sum is much richer than its parts. ${ }^{22} \mathrm{He}$ does not look at things in fractured terms. Instead, he aims at representing the multiple aspects of the world he sees as one unit. Grupo Corpo is ultimately a sum of dancers, experiences, social moments, dance styles, and choreographies that create one body. The group's name lends itself to a synonymous parallel between the dance company and Brazil. Grupo Corpo is neither a group nor a body but both. Without the group of dancers, directors, musicians, and composers that assemble the final spectacle and ritual, it is not a whole, a sum. The parts would not be able to function were they separated. Likewise, what is presented through the name Brazil is actually, as Mario de Andrade and Gilberto Freyre noted, a conglomeration of numerous cultural, racial, political, and geographic factors. One look at a map of South America reminds us of the vast geographic region the country occupies. It extends from the beaches of Bahia, to the Sertão, to the mountainous regions of Minais Gerais, to the Swiss-like south. Grupo Corpo represents Brazil: one nation that covers a vast and diverse geographic terrain and is construed by the very real experiences of contact between Africa, Europe, and the Americas.

\section{DANCE, EMOTION, AND SPECTACLE}

The choreographies that followed in the early part of the third phase explored nonlinear narrative forms. Rodrigo Pederneiras has stated that those pieces have no narrative thread or meaning, but after seeing several of them, I disagree. From my vantage point, I suggest that a number of the pieces underscore the stresses of industrialization on the body and invite one to think about experiences of alienation in the modern world. 
For example, when I saw Sete ou oito peças para um ballet, I thought about the ritual aspect of the theater. The moment of the performance felt, simultaneously, like a primitive ritual and a modern spectacle. In other words, I interpreted the performance as a ritual. It was repeatable but not reproducible. The lights that flooded the stage and the conspiratorial feeling of the audience awaiting a magical moment when the lights dimmed and the focus directed at another world - the lit stage, the rehearsed, and live motion-recalled, for me, a specific ritual gathering centered around an exhilarating experience of spiritual and intellectual communion. Randy Martin has noted, "The audience is not only part of the event's reason for being but also its means of becoming, which momentarily embodies the communicative idea of performance." ${ }^{23} \mathrm{He}$ argues, however, that "movement's 'object' is movement's purpose-its agency, if you prefer-but also its materiality as culture, its crystallization as experienced event." ${ }^{24}$ The contrast that Martin points to as the communicative idea of the performance and the crystallization of experienced event are what I interpret as performance as ritual.

When I viewed Sete o oito peças, I allowed myself to be transported to another world of illusion. The music was at once familiar and discomforting. It felt explicitly mechanical in many parts; but the dancers sometimes countered this when their movements became ripples reminiscent of movement in water. The elements were recalled throuth the choreography: water, fire, earth, and air. The dancers moved between patterns of unison, syncopation, repetition, and abruptness. As viewer, I was mesmerized by the action on the stage. The stage exuded energy as if it were molecular movement for the human eye.

Part of the stage was occupied by a large group of dancers, a crowd scene. In contrast, a solitary dancer in profile in a corner kept pace with the heartbeat in the music with nonstop sharp relevés ${ }^{25}$ with bent knees and sudden consistent contractions of the lower body. The "crowd" moved as a unit toward something. Could they be people in a subway or an airport? Could they be a colony of worker bees or ants? The steady movement was contrasted by the consistent tick - the quick, jerking plié and jeté-of a solitary dancer downstage on the right. I interpreted this dancer as a clock marking time. The music faded and a new sequence was introduced, an adagio of disconnected bodies. No one looked at the other. Even though they were performing the same steps, they were expressly not interacting. The looks on their faces emphasized boredom and isolation. Then, a new movement was introduced to the stage. The entire company was on, and the choreography emulated industrial mechanization with movements that reminded me of clocks, pegs, and other mechanical instruments. 
My interpretation of what was going on was inspired by the forceful repetition of dance steps. The bodies seemed to have become objects; the objects became machines; interjections of hip thrusts reminded me that there existed, nonetheless, suppleness implying human presence. This continued for long enough to drive a main thought: life is alienating, and comfort is found only in repetition, because it marks a degree of familiarity. However, after a while, the repetition also begins to feel alienating and frantic. I wondered how much longer the dancers could sustain such a relentless pace, paralleling mechanical movement but exhausting human capacities.

The insistent repetition and rhythm culminated in an abrupt halt. After all that noise and movement, silence suddenly pervaded the space. The only sound heard from the dancers was their heavy breathing from such athleticism. The audience's own respiration had been affected by this demonstration. The breathing was replaced by an enthusiastic explosion, the audience's burst of applause. The frenetic movement-normal for a machine, but too harsh for human bodieshad finally finished. The curtains came down and the ritual/spectacle came to an end. I thought about how the difficulties of life could be alleviated by a few breathtaking encounters with illusion. With these kinds of choreographies, Grupo Corpo became an international commodity, serving up spectacle of human possibility through technique and choreography. The story that came to mind with this supposedly nonnarrative performance focused on how people have been isolated by industrialization and its failed attempts at modernization. The performance of Sete o oito peças could have two meanings. On the one hand, it could point to human alienation. On the other hand, it could underscore the company's own separation from Brazil's many local realities.

I would like to meditate on this theoretically. For example, in The Society of the Spectacle, Guy Debord posits,

The whole life of those societies in which modern conditions of production prevail presents itself as an immense accumulation of spectacles. The spectacle appears at once as society itself, as a part of society and as a means of unification. As a part of society, it is that sector where all attention, all consciousness, converges. Being isolated-and precisely for that reason-this sector is the locus of illusion and false consciousness; the unity it imposes is merely the official language of generalized separation. ${ }^{26}$

"Spectacular society" is alienated from its origins. People are severed from the realities of everyday life. All that is left is a consumer society jonesing for the next spectacle and never satisfied; thus, Grupo Corpo courts the risk of becom- 
ing a spectacular representation emptied of the specificities of the history that have shaped it. But this does not happen. The troupe's position is double: it serves as a testimony of the modern aesthetic, both representing Brazil on an international level and affirming the possibilities of modern dance on a regional level. As a spectacle, the company might seem to be an alienated image in a world hungry for the new and the exotic, reproduced by pictures and advertising sound bites. This, however, points to the trajectory of success in Latin America. By becoming an object of international consumption, the group also becomes a local example of possibility through discipline, global dance languages, and international artistic engagements.

\section{THE BODY, CANNIBALISM, AND THE CITY}

The Brazilian national, sociopolitical reality in 2009 is dramatically different from what it was in 1976, when Grupo Corpo had its debut representing the nation with Maria Maria. Today's representations focus on crime-ridden favelas (shantytowns), which are inhabited by a largely Afro-descendant population. Films referred to as ghetto movies in the industry graphically highlight gang life. In particular, these films refer to a population explosion in cities because of the massive migrations from rural to urban areas.

Cities are at the epicenter, where claims for citizenship and rights are taking place. In their introduction to Cities and Citizenship (1999), Appadurai and Holston sum up the situation.

There is a broad criminalization of the poor at the same time that social groups at all levels come to support the privatization of security and the extralegalization of justice as the only effective means to deal with "marginals." In other words, there is a massive support for market forms of justice on the one hand (private security, vigilantes, enforcers) and, on the other hand, for extralegal and even illegal measures of control by state institutions, particularly the police (and related death squads) who kill large numbers of "marginals." This kind of violence further discredits the justice system and with it the entire project of democracy and its citizenship. ${ }^{27}$

With the continued criminalization of the poor and the marginalized and with a relatively lawless state, democracy is in a critical crisis. As a consequence, the struggle for democratic life is not only more acute but must be engaged creatively. Appadurai and Holston suggest, "As the social movements of the urban 
poor create unprecedented claims on and to the city, they expand citizenship to new social bases. In so doing, they create new sources of citizenship rights and corresponding forms of self-rule."28

The incipient violence that afflicts Brazilian urban cities has been clearly depicted by movies such as Pixote, Hector Babenco's 1981 award-winning film about a boy abandoned by his parents to the streets of Rio de Janeiro; O Cidade de Deus, Fernando Meirelles and Kátia Lund's 2002 film about violence in a well-known Rio favela; and Bus 174, José Padilha's 2002 documentary of the hijacking of a bus on June 12, 2000, in Rio de Janeiro. Bus 174, for example, underscores the dynamics of violence, its memory, and how myriad manifestations of violence emphasize exclusion. Sandro Nascimento, a marginal, poor, black youth, hijacked a bus and, for four-and-a-half hours, was televised cursing, accusing, and terrorizing his hostages at gunpoint. For four-and-a-half hours, the nation could not take its eyes off of the scene. He was murdered (once out of sight of the cameras) in the police car that should have taken him to prison and a later tribunal. This documentary raises many important social issues. Central are the origins and perpetuity of such extreme violence throughout Brazilian urban centers.

In a more complete and complex study of brutal transgressions in Brazilian culture, anthropologist Teresa Caldeira succinctly posits,

In its most general formulation, the dualist interpretation of Brazilian paradoxical developments suggests that Brazil has never become a fully modern society (a model identified with either Western Europe or the United States). Instead, Brazil is marked by a split between a hierarchical order (private, informal, personal) and egalitarian order (public, formal, legal), and the two relate in complex ways to produce the peculiarly Brazilian culture. ${ }^{29}$

Caldeira brings Roberto DaMatta's work to bear on her own interpretation of the problem: for DaMatta, "the hierarchical order is the legacy of colonial (i.e., slave-based) relationships and institutions." ${ }^{30}$ Inheriting traditions of brutality borne out of slave culture, the police have power and continue to empower themselves by daily using unwarranted, random violence. Such mistreatment does not afflict all. It is written, "Brazilian legislation guarantees preferential treatment by the police and prison system to anyone with a college degree." ${ }^{31}$ Violence, according to DaMatta and Caldeira is constitutive of Brazilian social order. ${ }^{32}$ When viewing a documentary like Bus 174 , it is critical to consider its message and social implications within an individual perspective (Sandro be- 
comes individualized through violence) and a larger, extremely complicated social and political reality (violence is used as a mediator that changes the position of the marginalized to central, with a voice, a story, and an impact).

Sociologist Luiz Eduardo Soares, who is interviewed in the film, argues that Sandro was one of many invisible bodies in the city who were hungry for social existence. Consequently, high on glue or cocaine, Sandro put on a little show for the cameras, which incited him to become even more violent. The media usually seek the most sensational of events. In front of the cameras, Sandro morphed from being marginal, abused, and invisible to becoming powerful, abusive, and "famous." According to Soares, Brazilian society is to blame for this kind of violence; despite its democracy, it still espouses ideals of order and progress that marginalize and criminalize the poor, and it condones inhumane methods to clean the streets and make the cities safe. Middle and upper classes alike coexist with the poor but do not want them in their way. As a result, closed communities have popped up in major cities. Also, as Yvonne Bezerra de Mello, the social worker interviewed in the documentary, points out, when polls were taken as to whether the street children should be eliminated at any cost, many people responded clearly. They wanted the "grime" off the streets. That "grime" happens to be human bodies, made invisible by their poverty. Soares notes that there are two ways of producing invisibility: one can be made invisible if the other's presence is neglected, and one can be made invisible if a stigma is cast over the presence of the homeless, thus replacing the singularity of a life with the prejudices of the dominant class. The disparities between the homeless and favelados (those who live in shantytowns and squatter colonies right alongside major cities and, often, affluent neighborhoods) still recall the cleansing projections of the dictatorship and military periods of Brazilian history. Bus 174 gives a voice and a history to the tragic life of Sandro and asks the viewer to rethink the bewildering infrastructures of violence.

When Sandro was six, his mother was stabbed to death. He was a solitary witness, screaming for help; but nobody came to his aid. According to Bezerra, who knew him, this trauma led to his running away to the streets of Rio de Janeiro. In July 1993, he was one of sixty-nine street children "living" in the Candelaria Church area. In an interview with one of the survivors, he remembers how some of the boys had had an earlier altercation with some police, who promised to punish the boys. It was a weekend, and the children did not take the threats seriously. But between eleven and midnight, a van pulled up to the area in the street where they slept. The youngsters believed that it was a soup truck, and all went over for some food. Instead, policemen jumped out and 
started shooting. Seven were killed, and sixty-two escaped. Yvonne Bezerra has studied the plight of the children who survived the massacre at Candelaria. Thirty-nine were murdered under different but equally violent circumstances, others disappeared, and the few who remain live in extremely precarious conditions. She notes that these children escape extremely abusive homes and go on to even more ruthless existences on the streets. Their lives are diminished to nothing - they have nothing to lose and can explode at any given minute.

Sandro was one of the survivors who lived to witness, tell, and retaliate. The film traces Sandro's life and interviews the people who knew him. During almost two years, he studied capoeira with Gil Velho, but this access to an art form did not help recuperate him from the path of anger and hatred. I want to believe that many happy stories can be incited by the arts, but it is also critical to understand the limitations. A capoeira dancer, Coelho, laments that Sandro was too hooked on glue sniffing and cocaine to be saved. (Sniffing glue is a common practice among street children that allows them to forget their hunger, and it is both addictive and lethal.) After years of incarceration and street life, Sandro's life was simply lost. According to Soares, boys like Sandro are hungry for social existence, and Sandro do Nascimento found his hours of social existence and inclusion through extreme violence.

I have detailed central parts of this documentary film not only to focus on the realities of ignored bodies and marginalized lives but also to invite considerations of alternatives to violence. In effect, the problem is economic, reflected on a defunct educational system, which further distresses the role of active citizenship in major cities and their corresponding nations. Education specialists Nelly Moulin and Vilma Pereira have noted,

Since the "economic miracle" of the 1970's, Brazil's economy has undergone successive recessions that have impoverished the wage-earning classes. Such drastic economic and social changes have had a profound effect on the socialization of all Brazilian children. Schools, responsible for shaping citizens and preparing children for entry into the economy, have assumed some of the socialization functions previously performed by the family. But Brazilian schools are unable to perform satisfactorily their traditional duties to mold citizens and workers. $^{33}$

With such severe limits on education, many are systematically precluded from citizenship, rights, and basic life possibilities. At this point, reminiscent of the slave period, music and dance both step in to offer alternative modes of sur- 
vival, resistance, and existence. Numerous studies have paid attention to this phenomenon. For example, anthropologist Victor Turner examined the role of the arts in marginal lives through his work on capoeira in the favelas. Turner claimed that the martial art gave the children and the communities something to focus on and relief from poverty's destructive effects. Barbara Browning's groundbreaking studies of samba and other popular Afro-Brazilian dances offer more nuanced analyses signaling both resistance and the insidious presence of racism and sexism in cultural interpretations of the AIDS epidemic. Most recently, the 2005 documentary film Favela Rising, directed by Jeff Zimbalist, focuses on another young, urban poor male to show that crime is not the only answer to invisibility. Similar to the circumstances of Bus 174, the war is between the police and the poor. In this case, drug lords in a Rio de Janeiro favela killed four policemen. In retaliation, the police slaughtered twenty-one of the shantytown's residents, regardless of their innocence to the previous crime. This documentary focuses its attention on Anderson Sá, one of the witnesses and survivors of the event. Certainly, he could have turned to greater violence, as was the case with Sandro; instead, he founded Grupo Cultural AfroReggae. The documentary tracks the work of this organization, which utilizes the popularity of music and dance to counter the violence and crime that the youth of that favela experiences daily.

So how does dance work its way into the city? How do cities that are being eaten up by violence reframe themselves to address the horrible results of invisible bodies wanting to make a mark? Anderson Sá offers some answers. Let us once again turn to the work of Grupo Corpo.

If the company lived through a period of its own version of anthropophagia, it did not explode as a victim of all it ingested. Instead, it has ingested experience and knowledge, and it is now sharing the nutrients (to continue the metaphor). Cultural, elite anthropophagia now confronts violent cannibalism of the masses that are desperately seeking a route to some kind of social inclusion and individual rights. Arguably, the moral demise of Brazilian society is a result of the modernizing project, which encouraged huge migrations to the cities. Almost two centuries ago, Schwarz aptly noted, "ways of rewriting the history of Brazil so as to understand the way that our backwardness formed a part of the development of modern society ... [help us understand that], backwardness was not something separate in the modern world, but a part of it." ${ }^{34}$

Much has been written on modernity, but these writings generally focus on the ills it has brought society. This leads me to pose a pertinent question: in a state of no return, wouldn't it be prudent to seek out alternative interpretations 
and modes of function that would lead to solutions? Artists, intellectuals, and communities can engage in an active dialogue between their crafts and their surroundings that could eventually help change the conditions of the cities they occupy. In order for dance to really be part of the city, it must embrace the histories of its people and the evolution of dance practice, both on and off the stage. Many small companies, NGOs, and alternative social programs are sprouting throughout the country to address the dire conditions of poverty and violence. Aware of the circumstances that highlight the clashes between the visions and projects of modernization in contrast to the astronomical rates of poverty, illiteracy, and crime that plague the country, five members ${ }^{35}$ from the body of Grupo Corpo initiated a project, Sambalelê, to bring dance to high-risk children on the borders of a favela in Belo Horizonte. Grupo Corpo, located at the center of a city surrounded by the poverty of shantytowns and challenged by growing violence, has turned its attention to its home city, Belo Horizonte.

In March 1998, Grupo Corpo initiated O Projecto Sambalelê, which brings music, dance, capoeira angola, and instrument classes to over 140 children in the Santa Efigenia region. Grupo Corpos's project statement describes the active role it plans to take in citizenship building.

O Projeto Sambalelê represents a step forward in this policy of collective action. It understands its identification with Belo Horizonte, with its population, with which it has created a passionate and reciprocal relationship for the past 24 years. With this project, Grupo Corpo can channel its accumulated experience to the most underprivileged segments of society by providing classes in dance, capoeira angola, music, and instrument making for the children receiving aid from sister sponsors ... Knowing that acts of solidarity make us a better people, a better Brazil, worthy of our cultural richness. ${ }^{36}$

Effectively, in 2000, the directors legally turned the growing outreach projects into an umbrella NGO, called "Corpo Cidadão." This program aims to help keep and/or get children off the streets-thus removing them from the oblivion of identity that tears at their lives-and to give them a sense of self and placement in the larger community. As per the mission statement, the project addresses the grave abuses experienced by street children and gives their otherwise ignored bodies the possibility of integration and citizenship. Concretely, 690 youngsters are enrolled in the program. When the director, Miriam Pederneiras, visited Ann Arbor with the photo exhibit Sambalele, she told the story of one child who went on to receive a scholarship to continue dance study at the 
main company studio. In the grand scheme of things, Corpo Cidadão reaches out to a very few. But Miriam insisted on the importance of changing one life at a time, rather than giving up and helping no one, ignoring en masse the growing numbers of globalization's victims.

Of course, we could be cynical and ask why the company did not do social work before or if it is not incited more by government tax breaks than by honest social concerns. Perhaps, I think, those are not the questions that merit sustained attention, since what counts is that important outreach work is being done. Perhaps we should welcome tax breaks, as they may be a key to indirect governmental support for the poor. Nonetheless, we must be aware of the documented impasses:

In the final analysis, while NGOs intend to help ameliorate the problems of street children and adolescents, by and large, they have instead perpetuated their problems because NGOs fail to help children get off the streets, to redirect them to their families, or to support their families. ${ }^{37}$

Indeed, studies suggest that citizenship is not so easy to attain as more complicated issues, such as home residency and family structures, are implicated. Still, could we hope that dance, with its transnational possibilities, might help get at least a few off the streets and onto the international stage? Could we envision an entryway into a paying job, an international skill, a home to build on, and a global world of open doors initiated by dance and performance?

I believe that Grupo Corpo and Corpo Cidadão offer a case study of growing examples of how dance/performance and the community/surroundings can connect to actively modify the conditions left behind by the debris created by failed modernizing projects in Latin America and by the new hierarchies brashly forged by the injustices of neoliberal economics and globalization. On the global level, Grupo Corpo has fulfilled an insatiable need for the spectacular and put the modern dance movement in Brazil on the map of international culture. On the local level, it is an integral part of the city of Belo Horizonte. Over the many fruitful years of its existence, it has trained dancers, offered scholarships to the children of the periphery, held special free performances for the public schools, and introduced an international dimension to its hometown. No longer is modern dance a rebel movement against and in response to classical ballet in Europe and the United States; instead, it is an interactive agent of multiple narratives of tradition and progress in cities such as Belo Horizonte. 
Brazilian cities mirror a series of classifications inherited from a long history of slavery, This inheritance is presently deployed by growing favelas and new "walled cities." Dance is a potent venue to defy established divisions between the rich and the poor.

\section{CONCLUSION}

Twenty-first-century reality is haunted by continued economic failures and plagued by growing violence. The spectacle of dance in the theater, only available to a select audience, is indeed another factor of modern alienation; but dance can play a role in the education of its environs when it is brought back to specific local sites. Spectacle is a complicated and important part of consumerism, recalling Néstor García Canclini's theory of consumers and citizens.

In this essay, I have described how Grupo Corpo concatenates with the historical trajectory of Brazilian modernity and impacts citizenship building. By examining the interrelated historical, artistic, and sociopolitical worlds, I hope to have exposed some of the links between the stage and the city, global culture and regional problems, and international spectacle and local realities. The company's work, as it has evolved over the years, emphasizes the plurality of histories, races, ethnicities, memories, rhythms, and possibilities. Dance creates constellations of communities, locally and globally, and thus reconfigures modes of belonging to community and nation.

In New York City, Angolan dancer and choreographer Júlio Leitão heads a group called "Batoto Yetu" that works with inner-city children, bringing them out of high-risk situations. Leitão has also worked in Brazil with Grupo Corpo, where new works were choreographed that included Angolan dance tradition, Brazilian rhythms, and Afro-American compositions. Similarly, in the United States, groups like the Alvin Ailey American Dance Theatre work very closely with inner-city children, bringing them a sensibility of the arts and survival that would otherwise remain amiss. The great late Katherine Dunham worked for years in Haiti, New York, and Brazil. Her anthropological dance research, revival, and choreography not only kept the transatlantic rhythms of dance, survival, resistance, and community alive but also introduced and integrated new ways of valuing the self, creating community, communing with a growing global culture, and challenging the abhorrent violence that the global economy wreaks on the poor. Dance transcends national borders, retains traditions, and, because of its nonstatic quality, confronts the ruins of late capitalism on a global scale, inciting us to consider the possibility of wider sociopolitical inclu- 
sion and its effects on local lives. The initial transatlantic trades that brought African lives to the Americas constitute a foundational history that is repeated by new formulations of violence manifested by police states and globalization's many injustices. Equally, as a challenge, the African rhythms that have mutated over the centuries inform new modalities of social renewal and expand citizenship to new social parameters.

\section{Notes}

Research for this essay was made possible by a Rockefeller Foundation Postdoctoral Fellowship administered by Wander Melo Miranda at the Centro de Estudios Literarios at the Universidade Federal de Minas Gerais; the generous welcome, support, and information proffered by Grupo Corpo; and a semester's leave and supplemental support from the University of Michigan. Muito obrigada to everyone in São Paulo and Belo Horizonte who gave of their time, resources, and contacts. Early guidance from my college mentor George Yúdice put me on track with this research as I wrote the proposal: obrigada, Profe. Special gratitude is extended to Maralice Souza de Neves and Charles Bicalho. Thanks also to Sueann Caulfied and Elizabeth Martins for proofreading my translations. A nascent version was presented to the Latin American and Caribbean Studies Program Brown Bag Series, and an abbreviated version was presented at the Atlantic Studies Initiative Conference "Rhythms of the Atlantic World," both at the University of Michigan in Ann Arbor. A part was also presented at the 2006 Ford Conference at the National Academies. Special thanks go to Yvonne Daniel for her continued support and conversation with respect to my longer-term ethnographic project. Many more of her wonderful points will be incorporated in the resulting book.

1. Appadurai and Holston, introduction to Cities and Citizenship, 14.

2. Doris Sommer's work on cultural agents to bring change to crime-stricken Latin American cities is crucial here. For example, she emphasizes the story of how, during his two terms in office, the ex-mayor of Bogotá, Antanas Mockus, was able to reduce the crime rate by putting mimes in the street and using creative venues to alter the levels of aggression and violence in the city.

3. García Canclini, Consumers and Citizens, 47.

4. In the 1992 book Imperial Eyes, Mary Louise Pratt based her study around the concept of "contact zones." For her purposes, she used this terminology to "refer to the space of colonial encounters, the space in which peoples geographically and historically separated come into contact with each other and establish ongoing relations, usually involving conditions of coercion, radical inequality, and intractable conflict" (6). She later elaborated, "A 'contact' perspective emphasizes how subjects are constituted in and by their relations to each other. It treats the relations among colonizers and colonized, or travelers and 'travelees,' not in terms of separateness or apartheid, but in terms of copresence, interaction, interlocking understanding and practices, often within radically asymmetrical relations of power" (7). It makes sense that Pratt, focusing on the eighteenth century, expounded on colonial encounters and offered a new reading of these 
dynamics. For my own work, I depart from her definition and propose an investigation of present-day contact zones created by market culture in a twenty-first-century global world. By examining the artistic production of a particular dance company and setting it against the backdrop of a longer history of Brazilian aesthetic and economic modernity, I describe new contact zones of representation and identity formation. The sites of contact that I analyze are carried out in spaces of performance.

5. Oswald de Andrade, translated in Schnapp, "Biting the Hand That Feeds You," $245-46$.

6. Castro Rocha, "Let Us Devour Oswald de Andrade," 7.

7. Castro Rocha presents anthropophagy as a problem that begs a contemporary reanalysis. In "Let Us Devour Oswald de Andrade," he argues that "discourses about identity are essentially useless, because they are inevitably tautological" (5). His essay presents an important overview of "the modernist writers' . . re-reading of anthropophagy" (8). He quotes Frances Picabia's Dada Cannibal Manifesto from 1920 and mentions Fritz Lang's 1926 factory whose "production core turned into an enormous mouth fed by the workers' bodies" and Paul Valéry's ideas interpreting artistic influence as a "matter of digestion" (12). Castro Rocha agrees with Mário de Andrade's presentation of the anxiety of cannibalism as a result of the trauma of World War I. Even with such literary and historical contextualization, Oswald de Andrade's systematic exposition of anthropophagy engaged a uniquely Brazilian process of ingestion of foreign materials and national production.

8. Ibid., 6 .

9. Barci Castriota, Arquitectura da modernidade, 19.

10. This concept is used in Shakespeare's The Tempest, Karl Marx's Communist Manifesto, and Marshall Berman's All That Is Solid Melts into Air.

11. Quoted from Buck-Morss, Dialectics of Seeing, 160.

12. Rodrigo Pederneiras choreographed Cantares, first performed at the Teatro do Centro de Arte Corpo in Belo Horizonte in 1978. With this piece, he made his debut as the company's official choreographer. However, during this period, it was Maria Maria and Último Trem that defined most keenly the company's production and popularity.

13. With the exception of the 1988 performance of Mulheres, which was choreographed by Susanne Linke.

14. See Katz, Grupo Corpo, for exact dates of opening performances.

15. Schwarz, in Beverley, Aronna, and Oviedo, Postmodernism Debate in Latin America, 281.

16. Most dance companies cannot survive without state and/or private sponsorship. Luckily, in 1989, Shell became an official corporate sponsor of Grupo Corpo, which was the first dance company in Brazil to find corporate interest that committed financial support to further the evolution of the creative dance work without imposing any restrictions on its production. Such clear-cut support guaranteed the company's stability for almost a decade. Many other companies have since followed this example of corporate and creative union.

17. "Maria Maria é mais que o roteiro de uma mulher pelo caminho de seu destino, algo assim como o cainho de uma mulher em direçao a solidariedade humana" (Martins, "Maria Maria," 11). 
18. From program in Spanish distributed during performance in Argentina in 1970 . "María María, un simple nombre de mujer. Cuerpo Negro de blandos secretos, ojos vivos olfateando la noche, brazos fuertes trabajando el día ... Un ir y venir cocineras preparando manjares para alguna gran cena. Entre ellas, María. Mientras revuelven las ollas, recuerdan a sus antepasados ... Los esclavos rememoran a su tierra de origen, su natural libertad ... Golpeados y heridos, siempre está presente en ellos el recuerdo de los dioses que veneraban en su tierra, sus diosces africanos ... pero en Brazil hay otros dioses, que ellos descononcían a cuyo influyo no pudieron escapar ... En su lecho de muerte, María dice sus verdades, con profunda tristeza y férrea esperanza. Luego, la muerte, el entierro. Todos cantan su canto de muerte, su credo ..." Due to spatial constraints, I do not elaborate this point here. An excellent study is presented by historian John Chasteen's National Rhythms, African Roots: The Deep History of Latin American Popular Dance, whose examination of African Dance, María de la O, and other important connections historically between popular dance, African dance, and staged dance merits sustained comparison in another venue.

19. I say "innocent" here because during interviews with the Pederneiras and Carmen Purri, they all claimed not to have been conscious of any rebellious act against the nature of things at the time. They mentioned that while they had to perform the piece before opening night to censors, they were not restricted in any way with what they did. Carmen Purri remembered that only minor changes were made to some sections upon the censors' recommendations. Of course, I wonder how much of that unspoken continued censorship remains when recalling that period of the company's initial years.

20. A "Mineiro" is someone from Minas Gerais.

21. "Eu sou uma preta velha aqui sentado ao sol."

22. "Que existe sempre uma coisa mais rica ... é a soma" (Rodrigo Pederneiras, interview by Lucía M. Suárez, April 1999).

23. Martin, Critical Moves, 38.

24. Ibid., xii.

25. Relevé is a ballet term that refers to the motion of the foot by which the heel is lifted and all body weight is concentrated on the ball of the foot and the toes.

26. Debord, Society of the Spectacle, 10.

27. Appadurai and Holston, introduction to Cities and Citizenship, 15.

28. Ibid., 12.

29. Caldeira, City of Walls, 140.

30. Ibid.

31. Ibid., 142.

32. Ibid.

33. Moulin and Pereira, "Families, Schools," 43.

34. Schwarz, Misplaced Ideas, xii.

35. Jacqueline Gimenes, Cristina Castilho, Carmen Purri, Pedro Pederneiras, and Miriam Pederneiras.

36. "O Projeto Sambalelê representa um passo adiante nesta politica de atuação comunitária. Compreende a identificação do Corpo com Belo Horizonte, come sua populacão, junto à qual, há 24 anos, vive uma história apaixonada e recíproca. Com o projecto, O Grupo pode canalizar para os segmentos mais desprivilegiados da cidade seu 
acúmulo de experiência, proporcionando cursos de dança, capoeira angola, música e confecção de instrumentos para crianças atendidas pelas entidades parceiras . . . Sabendo que as ações solidarias nos fazem um povo melhor, um Brasil melhor, digno de nossa riqueza cultural" (from a 1998 uncopyrighted handout package seeking funds).

37. UNICEF, 1992, quoted in Moulin and Pereira, "Familes, Schools," 51.

\section{Bibliography}

Appadurai, Arjun, and James Holston. "Introduction.” In Cities and Citizenship, edited by James Holston, 1-20. Durham: Duke University Press, 1999.

Barci Castriota, Leonardo, organizador. Arquitectura da Modernidade. Belo Horizonte: Editora UFMG, 1998.

Beverley, John, Michael Aronna, and José Oviedo, eds. The Postmodernism Debate in Latin America. Durham: Duke University Press, 1995.

Buck-Morss, Susan. The Dialectics of Seeing: Walter Benjamin and the Arcades Project. Cambridge: MIT Press, 1989.

Burt, Ramsay. Alien Bodies: Representations of Modernity, "Race," and Nation in Early Modern Dance. New York: Routledge, 1998.

Caldeira, Teresa P. R. City of Walls: Crime, Segregation, and Citizenship in São Paulo. Berkeley: University of California Press, 2000.

Chasteen, John Charles. National Rhythms, African Roots: The Deep History of Latin American Popular Dance. Albuquerque: University of New Mexico Press, 2004.

Debord, Guy. Society of the Spectacle. New York: Zone Books, 1995.

García Canclini, Néstor. Consumers and Citizens: Globalization and Multicultural Conflicts. Minneapolis: University of Minnesota Press, 2001.

Habermas, Jürgen. “Modernity_An Incomplete Project." In Postmodernism: A Reader, edited by Thomas Docherty, 98-109. New York: Columbia University Press, 1993.

Holston, James. Insurgent Citizenship: Disjunctions of Democracy and Modernity in Brazil. Princeton: Princeton University Press, 2007.

Katz, Helena. Grupo Corpo: Companhia de Dança. Belo Horizonte: Salamandra, 1995.

Martin, Randy. Critical Moves: Dance Studies in Theory and Politics. Durham: Duke University Press, 1998.

Martins, Sylvia. "Maria, Maria: A Música e a Mulher de Minas Num Contexto Universal.” Minas Gerais: Suplemento Literario, April 3, 1976.

Melo Mirando, Wander, ed. Narrativas da modernidade. Belo Horizonte: Autentica, 1999.

Moulin, Nelly, and Vilma Pereira. "Families, Schools, and the Socialization of Brazilian Children: Contemporary Dilemmas That Create Street Children." In Children of the Streets of the Americas: Globalization, Homelessness, and Education in the United States, Brazil, and Cuba, edited by Roslyn Arlin Mickelson, 43-54. New York: Routledge, 2000.

Pratt, Mary Louise. Imperial Eyes: Travel Writing and Transculturation. New York: Routledge, 1992.

Rocha, João Cezar de Castro. "Let Us Devour Oswald de Andrade: A Rereading of the Manifesto Antropófago." In "Anthropology Today?" edited by Jorge Ruffinelli and João Cezar de Castro Rocha. Special issue, Nuevo Texto Crítico 23-24 (2000): 5-19. 
Schnapp, Jeffrey T. "Biting the Hand That Feeds You (On the 7oth Anniversary of the Manifesto Antropófago).” In "Anthropology Today?" edited by Jorge Ruffinelli and João Cezar de Castro Rocha. Special issue, Nuevo Texto Crítico 23-24 (2000): 242-47. Schwarz, Roberto. Misplaced Ideas: Essays on Brazilian Culture. London: Verso, 1992.

Sommer, Doris. Review 71, "Art and Accountability." In "Review 71: Celebrating the Americas Society's 4oth Anniversary with a Special Supplement on Cultural Agents," 40th anniversary edition, Review 71 (November 2005): 261-314.

Turner, Victor. The Anthropology of Experience. Urbana: University of Illinois Press, 1986. 


\section{Muscle/Memories: How Germaine Acogny and Diane McIntyre Put Their Feet Down}

\section{SUSAN LEIGH FOSTER}

In this essay, I stage a duet between two contemporary choreographers, one Senegalese and one African American, both women of roughly the same age. I try to decipher the distinctive ways in which they vivify their African heritage in order to gain additional perspectives on how the body might participate in creating a sense of agency for a subject under duress. This inquiry grows out of my attempts to theorize tactics of resistance as more complicated and diverse than the terms resistance, opposition, mimicry, or strategic essentialism seem to allow. Although many of these terms implicate physicality in the project of contesting and undermining hegemony, I want to expand and also historicize the repertoire of corporeal techniques that could be implemented when confronting empire.

Pierre Bourdieu and Michel Foucault have shown that what gets stored within physicality as tacit knowledge includes memories from a cherished past about how to do things and also patterns produced by and from within systems of oppression. Theater historian Joseph Roach theorizes this systematic incorporation and reiteration of structurings of domination as a process in which bodies and places together construct vortices of behavior-patterns of action that congeal and become perpetuated over time. ${ }^{1}$ Bodies in the present are summoned into these vortical operations through a process of surrogation in which present bodies flesh out the gestures of the past. In what follows, I want to chart possible structurings of noncompliance with these gravitational flows.

Several dance scholars will be dancing along with these two choreographers, helping me to understand and describe their work. Brenda Dixon- 
Gottschild, inspired by Robert Farris Thompson, was the first to identify Africanisms such as polycentrism, high-affect juxtaposition, ephebism, and deadpan as central to an Africanist dance aesthetic. Examining the appropriation of these traits by choreographers such as George Balanchine and the postmodern Judson Church group, she showed how an Africanist aesthetic served to vitalize high and white forms and give them their cool. Thomas DeFrantz, building on Dixon-Gottschild's work, has also complicated the analysis of African American identity with considerations of sexuality and class in his study of Alvin Ailey. Kariamu Welsh Ashanti has illuminated the deeply complex and intertwined relationship between music and dance in African cultures, and Jacqui Malone has demonstrated this relationship in a variety of African American popular dance forms. Veta Goler has provided a powerful feminist analysis of the African American female body. Halifu Osumare, in her studies of hip-hop, has shown how to track the migratory paths of this world dance form. This essay builds from their visionary scholarly initiatives.

Here, I also want to explore possible meanings of a phrase commonly utilized in a variety of dance parlances: muscle memory. Dancers frequently refer to muscle memory as the capacity for memories to be stored in and evoked by movement of the musculature. Sometimes these memories are personal and psychological. At other times, memories insinuated into muscle reference cultural and historical experiences of a people. In this application, the term approximates the concept of embodied memory, also used to signify what Diana Taylor has called a "repertoire" of movements through which history is summoned up and reinvoked. ${ }^{2}$ Yet how, exactly, are such memories housed in the muscles? How are they acquired, and how do they endure? What, exactly, do they remember? I will propose that dancing has the capacity not to remember but, rather, to re-member, or to reattach the body to a cultural heritage in various ways. Dancing does not activate some historical past that lies dormant in the body, and the musculature does not function as a storage facility into which the past has been packed. Instead, dancing, as a set of actions, vitalizes a connection to past instances of dancing and other ways of moving. Both the muscles and the nerves that activate them engage in movements that reference, while never being the same as, a past way of moving.

In the same way that there can be no absolutely faithful replication of past movement, so there is no singular way to "put one's foot down." This phrase, colloquial for taking a firm stand on an issue, also implies an act of resisting. In what follows, I use the phrase to signify physical actions through which a resistive practice is constructed. Although "putting one's foot down" could suggest 
that one assumes a static and rigid position, choreographers Germaine Acogny and Diane McIntyre have each put their foot down repeatedly over the span of their careers, performing a move that has developed over time in relation to a changing point of contact. Their postures thus remain flexible and responsive to the moment in which there are engaged.

Before reading further, please focus on your foot for just a moment. What does your foot know at this moment? The texture and warmth of a sock or the contour and limits of a shoe? The sense of a thong between big and second toes or the circulation of air through space? What does your foot sense about its orientation in space at the end of the leg? It knows the angle of its extension from the calf and the degree of tension in all of its parts. Perhaps it registers the results of earlier actions in the form of pains, aches, weariness, or agitation. Perhaps it manifests the effects of routines or training regimens that have cultivated its structure, strength, or flexibility. Reading its physicality, what might we learn about what this foot remembers?

Germaine Acogny is the daughter of a Senegalese functionary who went to school in France to acquire the skills necessary to administer the colony and who also learned there to abhor dancing. ${ }^{3}$ Much to her father's dismay, Acogny showed exceptional talent at dancing from an early age. Like him, she went to France, where she studied ballet and modern dance in the early 1960s. Returning to Senegal, she began teaching dance classes in the courtyard of her home and also in the lycée where she was hired to be in charge of physical education. In these earliest classes, she began to develop a codification of what she calls "African dance" steps, inspired by the dance techniques she had learned in France. Although she borrowed from ballet its categorization of positions and steps and, I would argue, also a spatial stability to each position's look, she did not incorporate ballet's insistence on the geometric structure informing the poses.

The moves in her vocabulary continue to require a groundedness-a sense of dynamism moving from the ground up through the feet and inhabiting the entire body-that she describes as specifically African. What might it mean to be grounded? Does it refer to a distribution of weight, a quality of attentiveness, a focus on the body's core, or maybe all of these? Or do concepts such as "weight" and "core," in their assumption of universal applicability, run counter to the specificity required to relate foot to ground that is necessary for groundedness to emerge? Is groundedness a universal trait, or does it vary from ground to ground? 
In his study of the colonization of Australia, Paul Carter has argued that taxonomic projects, such as Linnaeus's classificatory system for botany, extracted each object of scrutiny from its ecology, "its historical and geographical surroundings. It loses all power to signify beyond itself, to suggest lines of development or the subtler influences of climate, ground and aspect. In short, its ecology, its existence in a given, living space is lost in the moment of scientific discovery." Groundedness, then, might require an enduring sensitivity to the relationship between the land and the body, a relationship that is specific to a particular land and a particular body.

Acogny's adaptation of ballet could seem to jeopardize her dance's groundedness, especially since ballet's classification of positions and steps comes out of a taxonomic project similar to that of Linnaeus. Along with all the academies of science, Louis XIV established the Academy of Dance, and sometime in the 1670s, he ordered his principal dancing master Pierre Beauchamps to "discover the means of making the art of dance comprehensible on paper." According to Beauchamps, he set about "shaping and disposing characters and notes in the form of tablature in order to represent the steps of the dances and ballets" in such a way that they could be learned "without need of personal instruction."

Three features of this mandate stand out as crucial to the way in which it disciplined the body's movement. ${ }^{6}$ First, it invented a regularized vocabulary of universal actions subtending all steps. Movement's significance was thereby reduced to a set of possibilities to elevate and lower, to move along a specified path, or to articulate rhythmic patterns with the legs and feet. Using this single classificatory rubric, the notation subjected dancing to laws that all movements appear to share. Cultural and historical specificities of particular dances were smoothed out or erased through the implementation of absolute conceptions of vertical and horizontal space as well as metricized time. ${ }^{7}$ Second, this system consolidated a single point of view from which to assess the body's progress throughout the dance. Rather than recalibrate one's actions in response to the movements of those around one, the dancer was taught to maintain awareness of his or her path in relation to a maplike rendering of the entire space. Third, the notation had as a principle objective the elimination of personal instruction. Body-to-body transmission of information was to be replaced by a textual literacy, one that would enable a much wider circulation of dances and also authorship rights to them. Taken together, these three features of the notation project had the effect of uprooting the body from its specific locality and establishing universal standards for the performance and teaching of dance. ${ }^{8}$

Although the dance notations that resulted from Louis XIV's mandate did 
not circulate widely, the pedagogical assumptions underlying this dance notation continued to inform the development of ballet up through the twentieth century. Acogny borrowed from this ballet pedagogy its identification of positions and steps, using it to establish a basic repertoire of moves for a new panAfrican dance form. Yet this borrowing enabled her to defy the colonizing project that the taxonomy had originally facilitated. Against the stereotypic Western conceptions of African dance as natural, impulsive, or genetically encoded, she used this codification to demonstrate its discipline, its virtuosity, and its artistry. Against the Western assertions about the unknowability of African dance, its "lascivious" tendencies or "chaotic" energy, she proposed a clear curriculum of study and identifiable criteria of competence.

Not only did she refashion ballet's classificatory framework into an anticolonial project, but she also infused its pedagogical precepts with new values. Specifically, her insistence on groundedness asks dancers to sense a variegated earth rather than to perform on an unmarked horizontal plane. For example, her current school, Ecole des Sables, boasts an exquisite, open-air dance studio with a sand floor. Students practicing technique experience the uneven terrain, the slight changes in pitch and texture of the ground, with each step they take. Thus, her approach affirms one's ability to respond to that earth in idiosyncratic or improvised ways rather than to execute a taxonomy of steps deriving from universal principles of movement. In addition, it insists on the need to learn the dance from another body rather than from a set of printed symbols.

Because of interest in codifying a lexicon of steps, Acogny was identified by Leopold Senghor, president of Senegal, and by Belgian-Senegalese choreographer Maurice Béjart, director of Brussels' prestigious Ballet du Vingtieme Siecle, to assist in the establishment of Mudra Afrique, one in a network of schools that Béjart hoped to establish to promote contemporary dance in relation to distinctive dance traditions worldwide. ${ }^{9}$ Initially Béjart specified the curriculum: daily classes in ballet, the Graham technique (based on the teaching of U.S. choreographer Martha Graham), Acogny's African technique, dance composition, and drumming. He also selected a Belgian director, who, in turn, chose the instructors. Of African ancestry, they arrived from Haiti to teach Graham and from the U.S. to teach ballet. Both men claimed to know African dance better than Acogny, and they attempted to take over her portion of her curriculum.

Acogny defiantly opposed this, confronting Béjart and refusing to continue with the project unless she was acknowledged as the sole director and authority of the school. Béjart consented, and Acogny, asserting her own leadership 
and reputation, allowed these foreign teachers to continue to teach their specialities. Thus, in her participation with Mudra Afrique, Acogny invited a colonial project into dialogue with her own dance practices, but she never allowed it to dominate. She put her foot down, offering Béjart her own leadership instead of the colonial structure he proposed.

As head of Mudra Afrique, Acogny maneuvered around colonial expectations in yet a third way. Teaching European students alongside those from several African countries, she learned to accept that their sincere efforts simply looked different. Rather than force conformance to a canonical repertoire, she began to integrate their variations into her teaching, thereby developing an ever-changing, constantly renewing practice. Even as the National Ballet of Senegal achieved increasing prominence, touring the world with its showcase of traditional tribal dances, Acogny defied the Western conception of an opposition between tradition and innovation, on which the National Ballet was based. ${ }^{10}$ Instead, she constructed an ongoing inquiry into African dance, treating its tradition as perpetually self-renewing. In addition, she began to forge a pan-African aesthetic, the hybrid product of the encounter between European contemporary dance and African forms, which extended beyond region or nation to invite participation from choreographers all over the continent.

Now look at your foot. Note the color of the skin. Survey the calluses, the exact shapes and lines of extension of the toes, the shape of the arch, the dryness or moistness of the skin. Look for scars, bunions, cracks in the skin. Note the length and color of the toenails. Does your foot indicate a class or gender or ethnic affiliation? What does its physicality say about its past? What do its appearance and internal sensations say about what it has been through?

At about the same time that Acogny was teaching in Mudra Afrique, African American Diane McIntyre graduated from Ohio State University, where she had received extensive exposure to modern dance through renowned faculty Vicki Blaine and Helen Alkire and such visiting artists as Anna Sokolow and Valda Setterfield. She moved to New York City in 1970 and founded her own company, Sounds in Motion, in 1972. As the name of the company suggests, McIntyre focused her choreographic inquiry on the collaborative interplay between music and dance, and she conceptualized musicians and dancers, equally, as members of a single company. In this interplay between sound and motion, McIntyre undertook to stage improvised choreography. Affirming improvisation as risky and cutting-edge, she also highlighted its history as an intrinsic feature of African 
American performance. Her dances used improvisation as a means to establish a danced dialogue about African American identity — celebrating and criticizing African American culture and, at the same time, casting its strengths and predicaments as issues of enduring human concern.

If Acogny was dancing within and against two hundred years of French colonial domination, McIntyre was dancing across the Middle Passage and all that it represented. Saidiya Hartman has shown that in the case of U.S. slavery, patterns of behavior have continued to mark the body and its cultural production more than a century after its supposed abolition. ${ }^{11}$ Hartman analyzes actions such as the slave being forced to dance on the auction block in order to sell himself by looking smart and lively. She demonstrates how these actions recur in minstrel entertainments as a central influence on such characters as the Sambo figure. ${ }^{12}$ Continually present even today in advertisements and popular culture images of all sorts, Sambo reiterates the master's mandate that the slave perform a simplistic enjoyment in dancing, one that proves the indefatigable and carefree disposition of the black body while also demonstrating the lack of intelligence and the subservience expected of subhuman beings. ${ }^{13}$

Hartman also suggests how dancing functioned to redress the pained and abject slave body. It fortified, in the face of "violent domination, dishonor, natal alienation, and chattel status," 14 the body held in servitude. Through such practices as "stealing away," in which slaves stole themselves away from the master to spend time in self-designated ways, or holding their own dances, in which they devised parodic versions of the master's social dances, slaves were able, partially, to stage a sense of their own agency. ${ }^{15}$

McIntyre determined to create anew this sense of agency by drawing on Africanist aesthetic principles such as the integral relation between music and dance. Buoyed by a substantial tradition of African American choreographers working in the modern dance tradition-Katherine Dunham, Pearl Primus, and Talley Beatty, among others — she worked to insinuate these principles into a contemporary moment where their enduring effectiveness could take on new significance. Unlike her predecessors, however, she also gave central place to improvised action. Improvisation functioned as an Africanist remembering, defying the Western opposition between choreography and improvisation, in which choreography is viewed as a fixed strategic plan and improvisation as an unstructured process of discovery. Working in a manner similar to jazz musicians, she asked dancers to improvise the choreography, making decisions in performance about how the dance would proceed. Not only did this use of improvisation confound traditional modern dance assumptions about the planned and 
the unanticipated, but it also functioned as a way of staging life on the edge, a highly pertinent focus especially for inner-city black culture resonating with the agendas formulated by the civil rights and Black Power movements.

In order to refine their improvisatory abilities and to forge an intimate relationship between music and dance, McIntyre and her company members spent long hours in the studio improvising with jazz musicians. Here they developed the abilities to trade rhythms; to imitate, embellish, or vary their responses to the calls of others; and to move beyond the familiar toward newly crafted movements and phrases. Prompted by this investigation, McIntyre also began to investigate earlier jazz dance forms and their histories in relation to the African diaspora. ${ }^{16}$ Two years after the founding of her company in 1972 , she traveled to Haiti, where she witnessed Vodou ceremonies and studied the integral relation between music and dance embodied in Haitian dance forms. Throughout the early 1970s, she also studied Lindy and its many variations, in order to deepen her understanding of possible relations between music and dance.

McIntyre worked with master dancers of the Savoy Ballroom era in order to establish the historical underpinnings of her own practice. From these studies, she expanded her vocabulary to include movement from the snake hips, jitterbug, cakewalk, truckin', Charleston, mess around, Suzy Q, and camel walk, and she was able to integrate these forms, their steps and their principles, with her modern dance background to achieve a distinctive and powerful signature style of moving. ${ }^{17}$ She also tapped the social dance tradition's mandate for inventive individualism as a way to approach collaborating with her dancers. Rather than develop a single vocabulary and technical standard against which all dancers were measured, McIntyre worked with dancers' individual strengths, building up a shared language of gestures and phrases that was implemented specifically for each piece.

McIntyre's interest in the past is particularly striking within the context of the modern dance tradition in which she had been trained. As defined through choreographic initiatives such as those of Isadora Duncan, Martha Graham, and Doris Humphrey, modern dance disdained the past, emphasizing instead the radical innovation in movement vocabulary. The choreographer might look to ancient mythology for the dance's subject matter, but the movement repertoire used to explore and express that subject necessarily appeared as new and individual. This newness helped to rationalize a new status for the female dancing body as elevated, spiritually motivated, and humanitarian-and hence radically distinct from representations in either ballet or burlesque. By con- 
ducting choreographic experimentation that ostensibly shunned both ballet and history, these artists secured an archetypal and universal status for their work.

As much as they claimed individual distinctiveness, the white modern choreographers' lexicons shared a striking commitment to groundedness, conceptualized and pursued in opposition to the nongrounded colonizing body of ballet. Unlike ballet, the bodies of these white feminist choreographers strongly moved into earth in order to reach toward the sky. Barefoot and unencumbered by corsets, embracing the earth and its gravitational force, they worked the body as dynamic flow between fall and rebound, contraction and release, centripetal and centrifugal momentums. Whereas ballet constructed an unmarked horizontal space into which the body ventures, these modern choreographers constructed an ahistorical interiority, whose universal impulses could be tapped and harnessed as impetus for movement. As in Feuillet's notation, the ground they embraced was thus rendered as ahistorical and unmarked, yet rather than a pure geometric space, the modern choreographers presumed an absolute gravitational flow that sustained all bodies equally within its dynamic tension.

With the psyche thus identified as purely individual rather than socially marked and with the ground identified as universal earth, these choreographers could place under erasure the inequities on which their success depended. As Susan Manning has shown, they largely ignored the absence of bodies of color on the concert stage, and, simultaneously, they indulged in their entitlement to represent all bodies. ${ }^{18}$ African American choreographers, such as Dunham or Primus, who attempted to participate in the modernist paradigm were thereby subjected to a double bind. They were seen either as "natural performers," when they foregrounded Africanist elements, or as "derivative," rather than "original," artists, when they attempted to experiment with more abstract vocabularies. Although black bodies began to populate the stage in larger numbers by the 1950 and 196os, they continued to be pressured to represent the specifics of their raced and classed backgrounds, while white choreographers could continue to claim the project of radical exploration of the new. For example, Alvin Ailey achieved renown for the depiction of African American life in the South or in Harlem, whereas Merce Cunningham's success grew from the ability to sequence the motions of unmarked, white bodies using chance procedures.

McIntyre's synthesis of historical materials and improvised action broke with the dominant white tradition of experimentation in modern dance, and it also radicalized African American modernism. Moving out from the Africanist 
connection between music and movement and using as source material events from African American history, literature, and popular culture, she showed work that was both historical and experimental. McIntyre grounded her choreographic project not in a place but in a process, that of continued improvisation with traditional materials. Like Dunham and Ailey, she drew from and valorized the tribulations and struggles that African American identity entails, yet she pushed beyond the depictions of specific communities and their narratives that her predecessors had utilized in their work. Instead, she showed a community of dancers, well-versed in traditional vocabularies yet capable of transforming them through inventive variation and recombination, who created new conversations about their contemporary world onstage. She put her feet down into the histories of white and African American modern dance, establishing a new way to affiliate with a specific identity and a set of universal concerns, both at the same time.

Now stop reading and go find another foot to compare with your own. Look closely at the differences in the size and shape of the toes, the arch, the heel. Note the differences in appearance, but also share the sensations that your foot is feeling with the other person. Together discuss these differences and speculate about their histories.

McIntyre's company Sounds in Motion operated within Harlem and beyond for over fifteen years, furthering the Black Arts Movement's rejuvenation of Harlem and also touring nationally. By the late 1980s, McIntyre decided to retire from running the company, because the business overtook the creative practice of making dances. She had to spend way too much time raising money and too little time working with dancers in the studio. Yet she has continued to work with groups of dancers and musicians on special projects, defying the pick-up company model of setting pieces quickly on hired dancers by working with artists for sustained periods of time.

After establishing a successful school of African dance in Toulouse, France, in the 1980s, Acogny began soliciting support for the establishment of a new school in Senegal. In 1998, Acogny celebrated the opening of Ecole des Sables, in Toabab Julau, forty miles south of Dakar. As in Mudra Afrique, Acogny has worked to create a strong sense of community between local inhabitants and the international students who attend the school. By inviting villagers to performances, integrating their labor and resources into the school's economy, Acogny keeps the village from becoming a museum, while affirming the 
lengthy history of its habitus. Acogny has further ensured that rejuvenation by canonizing a vocabulary, one that she continues to teach but that acknowledges the flexible interplay among all bodies that take it on.

McIntyre, in contrast, decenters and destabilizes the very notion of vocabulary by emphasizing improvisation and each dancer's distinctive skills of inventing and transforming movement. Her sense of community asks dancers to build together what it is that they share. Where Acogny tries to keep tradition alive by emphasizing the new, McIntyre incorporates history in order to keep the present accountable for the moves it makes. In these diverse ways, each choreographer has worked to build a community that is playful, critical, and continually renewing itself.

Both work to "re-member" Africa, yet each has formulated a contrasting set of tactics in response to distinct colonial histories. Acogny traveled to the colonizer, borrowing concepts that helped to elevate her own tradition in the colonizer's opinion. Accepting the colonial invitation to collaborate, she then used it to create Africa anew. Similarly, McIntyre schooled herself in traditional modernism but then constructed a radically alternative process of dance making, one that avowed her African American heritage while simultaneously constructing a new vision of the social and the ways that bodies can share and exchange movement. She moved out from a white tradition to uncover her own history, insinuating it into the white tradition in a way that both exposes and obviates the tradition's fundamental investment in whiteness.

Each choreographer's technique of putting her foot down is unique, responding to political and aesthetic exigencies of her moment. Acogny grounds her practice in a particular physical environs, cultivating an awareness of the specificities of a place called "Africa." McIntyre grounds her practice by cultivating the historical lineage of which she is a part. Both of these projects demonstrate how muscle memory is cultural memory and how cultural memory is muscular.

Now just give your calf a little massage. There are nine separate muscles in the calf that extend into the foot, enabling its ability to flex, extend, pronate, or supinate and to transfer the body's weight earthwards. See if you can sense their difference. Try to follow them from their attachment along the tibia or fibula across the ankle joint and down into the foot. Which ones are tense? Which ones are supple or twangy? Can you connect the pattern or muscular development to activities you perform regularly or to actions from your past? 
Turning for a moment to the investigations of perceptual theorists, we learn that muscles contain two types of nerve fibers, one that prompts the muscle into motion and a second that continually registers the amount of tension that the muscle is manifesting at any given moment. This second type of nerve fiber, called a "proprioceptor," delivers to the central nervous system the information concerning the ongoing location, whether flexed or extended, and effort, whether tensed or relaxed, of every part of the body. According to James Gibson, this information is then used as a point of reference in deciphering all forms of sensory input. ${ }^{19}$ Thus, our eyeball, for example, can give us relatively little visual information, but the eyeball in combination with the ocular musculature that surrounds it can tell us a great deal about our surroundings. Similarly, we know the location of a sound in relation to the orientation of the head as the sound is heard. We know what our foot is moving toward on the basis of how we are standing. These two kinds of nerves create what Gibson calls a "perceptual system." The senses do not passively receive stimuli that the brain then processes and determines a course of action, and the will (wherever that is located) does not command the muscles into actions such that they obey in order to produce action. Rather, sensation and action work together to create information.

Not only does action help to produce perception, but scientists are now positing that individuals, based on their heritage of past experiences, literally perceive the world distinctively. Neurophysiologist Alain Berthoz explains that "the oculomotor path followed to explore a face is completely different depending on what the observer is thinking: whether she thinks that the individual is rich, sad, or well-coifed, that his ears are protruding, and so on." ${ }^{20}$ Pleasure or fear or interest all influence the tiny motions of the eye, known as saccades, through which visual perception occurs. ${ }^{21}$ One's history of engagement with the environment profoundly affects how one sees and, consequently, what one sees. ${ }^{22}$ Knowledge production thus depends on the detection of a noticeable difference between two or more events, all of which are in motion.

Acogny's and McIntyre's careers make apparent this epistemological choreography. Each has persevered in an action of grounding rather than adopting a static posture or stance. They show us, each in a different way, that there is no absolute ground toward which the foot descends. Rather, the act of putting one's foot down entails a constant revaluing and reassessing of what is necessary to preserve dignity and claim worth. There is also no single action by which the leg moves toward and into the ground. Both bodies remain flexible as the leg descends, drawing sustenance from what is beneath, but not becoming hard as they defy that which is coming at them. However, Acogny has 
trained the sole of the foot as sensitized interface between the earthly and the corporeal, whereas McIntyre teaches it to weave between past and present.

Each choreographer thus re-members a past differently. In their teaching, in their work with groups of dancers, in their crafting of dances, each choreographer formulates sets of actions that build up a sense of the past. They actively create memory of a past through their commitment to a shared vocabulary of movements. These motions resemble a past way of performing and carry with them a history of significance, but they are only made meaningful through the consensus about them that is established as dancers and viewers collectively work out what they are doing and watching. Thus, Acogny and McIntyre do not use physicality as a storage unit within which some past set of actions is housed, nor do they bolster a body willing to proclaim a universal position from which to survey and remember the world. Instead, they vivify physicality as coproducer of memory: memory's pastness is defined by the presentness of the corporeality of the rememberer, and both are in motion.

Now stand up and then put your foot down. What is your foot feeling at this moment?

\section{Notes}

1. See Roach, Cities of the Dead.

2. See Taylor, Archive and the Repertoire.

3. Much of the following information about Acogny's life was acquired through a weeklong series of interviews with her that took place in the Department of World Arts and Cultures at the University of California, Los Angeles, in January 2004.

4. Carter, Road to Botany Bay, 22.

5. Quoted in Harris-Warrick and Marsh, Musical Theatre at the Court of Louis XIV, 84.

6. Literary historian Jean Noel Laurenti explains, "The French dancing masters had to unify a vocabulary of steps with diverse origins, from the provinces or from abroad: to discover what this vast repertoire had in common, it was necessary to first distinguish all the constituent parts. This would permit the use of the same signs (in different sequence of course) to note down a minuet or passepied, originally from the west of France, as well as a gavot or a rigadoon, imported from the southeast, or a "Spanishstyle" sarabande or chaconne. The Feuillet system thus reflects an approach which, by passing through the universal laws of movement, finally arrives at a kind of universal language of dance, allowing the different traditions to communicate" ("Feuillet's Thinking," 87 ).

7. See "Feuillet's Thinking."

8. Elsewhere I have argued that this project of inventing dance notation buttressed 
the colonial project. As Mary Louise Pratt and many others have argued, this disembodied synthesis of pure space and absolute viewpoint worked effectively to rationalize the colonial project. The corporeality that connected space and viewpoint extended itself outward from a central verticality toward a periphery, through an unmarked space. The act of moving through such a pure space was characterized as value-free, and any labor entailed in traversing this space went unregistered. Within such a space, neutral bodily features and motions, such as those specified by the notation, operated to confirm the existence of an absolute set of laws to which all bodies should conform. Implementing this bodily disciplining, the colonial regime could first institute protocols of comportment at home and then proliferate these standards and indexes of behavior to those foreign bodies that it desired to govern abroad. These protocols acquired their persuasive force by standing as the most basic and therefore universal units out of which human behavior is composed.

9. Acogny was brought to Leopold Senghor's attention when choreographing his famous poem "Femme Noire, Femme Nu," and he subsequently sent her to Brussels to be evaluated by Béjart. She had pressed on Senghor the need to include dance within his theory of Negritude, but he wanted Béjart's assessment of her philosophy and competence.

10. Castaldi, Choreographies of African Identities.

11. Her analysis attempts "to elucidate the means by which the wanton use of and the violence directed toward the black body came to be identified as its pleasures and dangers - that is, the expectations of slave property are ontologized as the innate capacities and inner feelings of the enslaved, and moreover, the ascription of excess and enjoyment to the African effaces the violence perpetrated against the enslaved" (Hartman, Scenes of Subjection, 26).

12. Hartman argues, "These displays of excess enjoyment seemed to suggest that the same natural law that established the liberty of all men also authorized slavery since the natural inclination of the enslaved was good cheer and they seemingly endured horrendous circumstances with ease" (Scenes of Subjection, 38).

13. Hartman writes, "This indelible image of a prostrate yet perky Sambo conjures up an idealized and fetishized state of servitude, in which the imputed consciousness of the enslaved ensures submission and docility more effectively than either the whip or the chain. In other words, the figure reconciles infantilized willfulness with the abject status of the will-less object" (Scenes of Subjection, 52).

14. Hartman, Scenes of Subjection, 72.

15. For an in-depth analysis of several of these defiant bodies, see Brooks, Bodies in Dissent.

16. The extent of McIntyre's research into the history of the Afro-American musical and dance traditions is particularly evident in Going North, 1881, a work that includes banjo songs, spirituals, harmonica, and slide guitar, and in the impressive diversity of musical sources used in her entire repertory.

17. McIntyre's efforts to transplant free jazz sequencing, with its rapid pace, startling disjunctures, and innovative harmonies, eventually consolidated a signature style of moving, described by Cynthia S'tembile West as follows: "Her jumps contain a torque, a suspension commonly seen in African dance, that freezes the dancer in midair. This re- 
quires rugged physical stamina, skill, nerve, guts, and knowing exactly when to 'take-off.' Precision and timing are crucial elements which heighten the drama and rivet attention. McIntyre's signature is defined by suspended buoyancy, swaggered sliding walks, hands flung out forcefully with each finger carving its own world in the space, and sustained balances that float on stage" ("Dianne McIntyre," 142).

18. See Manning, Modern Dance, Negro Dance.

19. See Gibson, Senses Considered as Perceptual Systems.

20. Berthoz, Brain's Sense of Movement, 196.

21. Ibid., 201.

22. Ibid., 221.

\section{Bibliography}

Berthoz, Alain. The Brain's Sense of Movement. Translated by G. Weiss. Cambridge: Harvard University Press, 2000.

Brooks, Daphne. Bodies in Dissent. Chapel Hill, NC: Duke University Press, 2007.

Carter, Paul. The Road to Botany Bay: An Essay in Spatial History. London: Faber and Faber, 1987.

Castaldi, Francesca. Choreographies of African Identities: Negritude and the National Ballet of Senegal. Urbana: University of Illinois Press, 2005.

Gibson, James J. The Senses Considered as Perceptual Systems. Boston: Houghton Mifflin, 1966.

Harris-Warrick, Rebecca, and Carol G. Marsh. Musical Theatre at the Court of Louis XIV. New York: Cambridge University Press, 1994.

Hartman, Saidiya. Scenes of Subjection: Terror, Slavery, and Self-Making in NineteenthCentury America. Oxford: Oxford University Press, 1997.

Laurenti, Jean Noel. "Feuillet's Thinking." Translated by Brian Holmes. In Traces of Dance: Drawing and Notation of Choreographers, edited by Laurence Louppe, 81-108. Marsat, France: La Source d'Or, 1994.

Manning, Susan. Modern Dance, Negro Dance: Race in Motion. Minneapolis: University of Minnesota Press, 2004.

Roach, Joseph. Cities of the Dead: Circum-Atlantic Performance. New York: Columbia University Press, 1996.

Taylor, Diana. The Archive and the Repertoire: Performing Cultural Memory in the Americas. Durham: Duke University Press, 2003.

West, Cynthia S'tembile. "Dianne McIntyre: A Twentieth Century Griot." In African Dance: An Artistic, Historical, and Philosophical Inquiry, edited by Kariamu Welsh Asante, 131-44. Trenton, NJ: African World Press, 1996. 


\section{"To Carry the Dance of the People Beyond": Jean Léon Destiné, Lavinia Williams, and Danse Folklorique Haïtienne}

MILLERY POLYNÉ

During the week of April 7, 1951, the Haiti Tourist Information Bureau (HTIB) and the city of New York sponsored a series of cultural events celebrating Haiti Week of New York. The festivities not only served as a platform to display the finest in Haitian culture but also functioned as an "appeal for collaboration" for the U.S. government and its citizens to fully participate in the economic revitalization of the Haitian republic. ${ }^{1}$ Key to the bureau's "appeal" was building a sound tourist industry in Haiti that encouraged "Americans from New York and other states of this great Sister Republic [to] get better and better acquainted with this Tourist Paradise that Haiti represents." ${ }^{2}$ The HTIB's reference to the United States as a "Sister Republic" echoed Franklin Roosevelt's Good Neighbor Policy, a U.S.-centered foreign policy that promoted nonintervention and cooperative economic and cultural programs in the Americas. Although there are ample critiques of asymmetrical hemispheric relations between the United States, Haiti, and a number of other Latin American countries, the Haitian government still courted collaborative financial ventures with the United States in order to alleviate Haiti's struggling economy. ${ }^{3}$

Haiti Week proved to be a critical moment in the development of Haitian tourism. Haitian cultural festivities in New York City were organized on the heels of significant political transition and economic depression in Haiti, particularly the coup d'etat against President Dumarsais Estimé by Paul E. Magloire in May 1950. Furthermore, operating within a politically charged environment of the cold war, where the absence of sociopolitical freedoms in the 
United States due to the threat of communism often pushed the more radical activist/intellectuals to call attention to the "cultural realm," Haiti Week can also be understood as a tool—or, rather, the stage in which — to advance the notion of material and cultural advancement. ${ }^{4}$ The reports and advertisements in the News of Haiti, an official publication of the HTIB, trumpeted Haiti's modern technical projects (construction of new roads and buildings), which offered the illusion of progress. ${ }^{5}$ Material advancement in Haiti accentuated the "illusions of pleasure" for the middle-class North American traveler despite the aftereffects of the nineteen-year U.S. occupation of Haiti, which offered minimal structural improvement and held the country in arrears to a number of U.S. investors. Celebrated Haitian and African American artists, dancers, and literary figures such as Jean Léon Destiné, Katherine Dunham, and Jean Brierre participated in Haiti Week programs, clearly sending the message that cultural arts, at this particular moment in time, served as Haiti's most valuable resource.

This essay focuses on the development of danse folklorique Haitienne (Haitian folkloric dance) by Jean Léon Destiné and Lavinia Williams and on how they employed it to entertain, to educate their audiences on Haitian culture, and to technically train Haitian dancers in the 1940s and 1950s. As early as the middle 1930s through the 1950s, the advancement and consumption of Haitian cultural arts gained full support by the Haitian government in order to develop Haiti's tourist industry. In fact, many Caribbean administrations encouraged tourism during this time in order to complement industrialization and answer the dilemma of debt, unemployment, and failing economies. ${ }^{6}$ The emerging popularity of Haitian dance, along with painting and music, attracted curious tourists and artists and also helped reinvigorate Haitian cultural production and consumption, which, in many ways, perpetuated elitist notions and racist images of Haitian culture as exotic and primitive.

The challenge for Haitian artists to escape "the trivialization of its culture as either exotic or demonic" in the minds of foreigners remained overwhelming. ${ }^{7}$ Influenced by the racist travel narratives and zombie films that proliferated the American landscape during U.S. occupation (1915-34) and postoccupation (1934-57), such as White Zombie (1932) and I Walked With a Zombie (1943), many tourists were intrigued by notions of a "primitive" and "mysterious" Haiti. Haiti was the Africa of the West, without the long voyage, and maintained some semblance of U.S. influence. Scholars Gérarde Magloire and Kevin Yelvington assert: "In the anthropological imagination of Haiti with its legacy of colonial and neocolonial ethnography, itself a cousin to travel narratives, 'Africa,' 'Vodou' and 'Race', among others, have remained key images in the rep- 
resentation of Haiti as a whole." with popular ideas, and the images of "Africa," "Vodou," and "Race" become "synecdoches, standing for 'African savagery' as part of a larger colonial discourse on the religions of 'primitive' people regarded as fetishistic, superstitious, [and] cannibalistic." Dance, Haitian folkloric dance in particular, among other cultural art forms, served as the vehicle for which many tourists would authenticate their racist and paternalistic beliefs. Destiné and Williams proved not to be completely successful in overcoming such bigoted perceptions of vodou and its sacred dances. Nevertheless, Destiné's and Williams's innovation and transmission of Haitian dance educated dancers and their audiences to Haitian and West African-based cultural heritage(s), helped to attract tourists, and also demonstrated that the cultural arts enhanced the modern project of economic and cultural development. ${ }^{10}$

I argue that their work sought to codify Haitian dance-discipline it, classify it, and theatricalize it—so as to exhibit Haiti's art form and its cultural ambassadors on the world stage and to educate their audience to Haitian history and culture. From the late 1940 os to 1956, the "golden age of tourism" in Haiti, Destiné and Williams transformed the pedagogy of Haitian folkloric dance by establishing national institutions in Haiti that focused on the technical development of dance (i.e., floor stretches, body conditioning, ballet training, choreography classes, etc.). ${ }^{11}$ The creation of a polished, well-conditioned and professional group of dancers, influenced by the class and cultural education of Destiné and Williams, presented a perceived cultured and more agreeable image to middle-class, liberal vacationers from the United States and Europe. More important, the establishment of cultural institutions and the training of Haitian dancers affirmed the creation of an alternative world by black dancers where African-based art forms were celebrated and in consistent dialogue with Western culture.

Haitian folkloric dance and Haitian paintings were arguably the most prominent and popular cultural art forms exposed to the international public. During the presidencies of Dumarsais Estimé and Paul Magloire (1946-56), the cultivation of Haitian art forms prospered because of noiriste state support, which promoted a dark-skin, populist agenda, and an effective public relations campaign that advanced Haiti's cultural capital so as to fascinate and charm potential tourists. ${ }^{12}$ However, this essay concentrates on the role of Haitian folkloric dance as opposed to Haitian painting or sculpture, because of its international exposure and acclaim, its choreographers, the magnitude of its audiences, its participatory elements, the frequency of its performances, and also its sym- 
biotic relationship with vodou religion and the growth of tourist entertainment structures such as hotels, clubs, and theater venues. Dance performances occurred in school auditoriums, theaters, open-air sites, and nightclubs entertaining small and large audiences on a nightly basis. ${ }^{13}$ The popularity of folkloric dance shows in theater settings motivated several hotels and clubs in Haiti to host performances similar to Broadway musicals and to appropriate the names of vodou divinities such as Hôtel Ibo Lele and its Shango Nightclub. ${ }^{14}$ Secular danse folklorique functioned as a more visible and tangible manifestation of sacred vodou ritual, the latter of which troubled the presidents Sténio Vincent (1930-41) and Élie Lescot (1941-46). The air of hopefulness that followed the end of U.S. intervention had also ushered in state-sponsored repression of sacred vodou, where Vincent and Lescot believed it to be politically and cultural regressive to the state and the (re)formation of Haitian national identity. Yet the state deemed folkloric dance- believed to be bled of its sacred elements-a viable cultural commodity to attract tourism. Therefore, folkloric dance, arguably more than Haitian painting, deserves particular attention to the growth of Haitian tourism, national development, and cultural nationalism.

\section{"WE HAVE AN ARTIST": JEAN LÉON DESTINÉ AT THE INTERSECTION OF FOLKLORIC DANCE AND VODOU}

In September 1935, some conservative elements of Haitian society, particularly Haitian elites and print media sources such as Le Matin, applauded President Sténio Vincent's legislation against les pratiques superstitieuses (superstitious practices). However, revisions in the penal code of the same year stated that popular dances or Haitian folkloric dance, void of any sacred ritual or sacrifice of livestock in submission to deities, were legal, despite their inextricable connections with vodou. ${ }^{15}$ Scholar Kate Ramsey asserted that these legislative changes occurred due to the development of cultural nationalism during the U.S. occupation period, which "mark[ed] the moment when it became politically desirable ... for the state to distinguish popular dance from prohibited ritual." ${ }^{16}$ Popular dance became evidence of a national culture and of Haitian cultural progress, while religious rituals perpetuated notions of Haitian primitivism and inferiority.

Since the late 1930s, the Catholic Church in Haiti promoted an antisuperstitious campaign with the support of the state. Intrusions by the Haitian police and Catholic clergyman on ounfò (temples) and other sites where Haitians were suspected of participating in vodou ceremonies disrupted worship and in- 
stilled fear in the practicing Haitian peasantry. Jean Léon Destiné, who was educated in Catholic churches and schools in St. Marc, possessed firsthand knowledge of the church's power on the Haitian aristocracy and middle class. Coming from a middle-class family of "modest means," Destiné explained that the Catholic Church "told us [Haitians] it [vodou worship] was a sin [and that] you're going to hell. All of us accepted it." ${ }^{17}$ In Haitian social politics, there existed a stark conflict between Christianity and vodou. Within the Haitian elite, Christianity operated antithetical to the complex philosophical and religious beliefs of vodou, the religion of the Haitian masses. It was perceived as backward and contradictory to Catholic theology. Yet the Haitian peasantry and certain indigéniste scholars, such as Jean Price-Mars, who critically advanced the cultural production of the Haitian masses, deemed vodou as symbiotic with Catholicism and also African-based. As Michel-Rolph Trouillot asserts, "to different degrees, they [elite and peasantry] shared religious beliefs rooted in the same African-dominated cosmology and took part in similar rituals." 18 This theological division along the lines of class was clearly noted by both Destiné and Katherine Dunham as they navigated the waters of folkloric culture and the illegal sacred rituals of vodou. Destiné stated, "Folksongs to them [the Haitian elite] were vodou songs-which is stupid! The minute there is drumming they think it's vodou." ${ }^{19}$ Dunham, an African American dancer and anthropologist, noted, upon her initial research trip in May 1935, how President Vincent "paid deference to 'folklore' for the sake of the growing interest of tourists in the island" but that "an air of secrecy clothed all the serious ceremonies." 20 The Haitian government, according to Dunham, frowned on "investigations" that unearthed the schism between "the thin upper crust of the Haitian elite ... [and] the black peasants, who really were by numbers and by historical content and character and humanness ... the true Haitian people."21 Destiné's and Dunham's remarks highlighted that class divisions, particularly ruptures triggered by elitist cultural denigration of vodou belief systems and vodou-inspired art forms, operated at the intersection of danse folklorique and vodou.

Destinés recollections of this class and legal conflict and its connections with Haitian national identity can be traced to an incident involving Lina Fussman-Mathon (a pioneering Haitian folkloric dance artist, pianist, and composer), a small group of young Haitian male singers/dancers, and the Haitian police. ${ }^{22}$ One Saturday night, Fussman-Mathon brought four boys (including Destiné) to a vodou ceremony in the rural section of Port-au-Prince, in order to expose them to the indigenous rituals and dances of the Haitian peasantry. Fussman-Mathon deemed it critical for their training because her dance and 
singing troupe had been formally invited to the National Folk Festival in Washington, DC. According to Destiné, this trip was his first direct introduction to vodou culture. Destiné trembled when he arrived at the ceremony, because he believed that he and the group committed sins against the Catholic Church. During the ceremony, members of the Haitian police force arrested the group of observers and participants. Destiné recalled the police reprimanding them, yelling, "Don't you know you are not supposed to be here?" Once they were brought back to the police station, Fussman-Mathon made a telephone call to government officials explaining that they were preparing for the folk festival in Washington, DC. The group was soon released with a strict warning. ${ }^{23}$ The troupe's release from police custody probably stemmed from several factors: President-elect Élie Lescot's support of the folk festival, the fact that the troupe trained to represent Haiti in the United States, and the influence of FussmanMathon and the boys' middle-class families. Yet the state's crafting of a modern image for Haiti was being challenged by the promotion of Haitian folklore, particularly dance, and its dependency on so-called primitive elements of the vodou religion.

In May 1941, Fussman-Mathon's folkloric troupe attended the National Folk Festival held in Constitution Hall, Washington, DC. Considered to be an example of Pan-Americanism at its best, the festival encouraged hemispheric cultural exchange and understanding. ${ }^{24}$ Destiné remarked that Haiti was one of the few countries that represented African culture in the festival. To his surprise, "there were no Cubans and no Brazilians" performing at the event. Brazil and Cuba, he asserted, were "the two strong African-influenced countries that could compete with Haiti," and "now we [the Haitian folkloric troupe] were the only real one that would bring Africa!" 25 Destiné's excitement about the troupe's representation of a West African-derived cultural past fused with Haitian elements may have been a product of many years of reflection on his part. However, it addresses varying angles of cultural perception and authenticity. From Destinés reading of the event, the dancers performed Haitian songs and dances inextricably linked with West African traditions, memories, and philosophies. Their creative involvement in the folk festival also afforded them the opportunity to travel, to obtain some level of notoriety and possibly access to monetary or cultural resources.

The Haitian state believed that the troupe's participation figured into a larger Pan-American project that could potentially reap the benefits of increased tourist activity and positive exposure for the nation. The reconciliation of these two views manifested itself in inter-American programs and Haiti's 
nouvelle cooperation, which explored ways to expand and strengthen relations between Haiti and the United States. ${ }^{26}$ African Americans, Caribbeans, Latin Americans and a few U.S. government officials understood that building and improving cultural programs and the exchange of ideas (economic, technical, and artistic) across boundaries might "break down some of the racial barriers in the U.S." and in the international arena. ${ }^{27}$ During the early 1940s, Walter White, executive secretary of the National Association for the Advancement of Colored People (NAACP), conveyed serious concerns to Nelson Rockefeller and others about the "success" of the Good Neighbor Policy if the United States did not address the issue of "color prejudice" and also highlight some of the contributions nonwhite citizens made to inter-American affairs. Robert G. Caldwell, a cultural relations official in the U.S. government, agreed with White. Caldwell affirmed that the United States could not "overlook ... the fairly complex racial question of Latin American peoples." ${ }^{28}$ Several intellectual and educational programs were implemented at the state and federal level, but few critically addressed race, racism, and imperialism in the Americas. ${ }^{29}$

The performance by the Haitian folkloric troupe at the National Folk Festival received enthusiastic reviews from the U.S. press, and according to Destiné, they frequently sent newspaper clippings back to Haiti. Destiné claimed that the Haitian people "couldn't believe" the overwhelming positive response given by American audiences: "You wouldn't dare do those things in [the Haitian] public ... and Washington was loving it." The troupe's exposure and acclaim planted the seed in Destiné's mind that he might have a future in dance in the United States, where monetary resources were more available and where audiences were much more welcoming.

When the troupe returned to Haiti, Destiné was forced to think about how he would make a living. He learned typography at the Haitian newspaper Le Nouvelliste during the summer of 1941 and later returned to the United States on a print media scholarship from the Rockefeller Foundation. ${ }^{30}$ Philanthropic organizations like the Ford and Rockefeller foundations often tailored their grants to U.S. foreign policy initiatives. In this case, President Franklin D. Roosevelt's Good Neighbor Policy and the ideals of Pan-Americanism encouraged technical development and international exchange in the Americas. Destinés Rockefeller grant functioned as an example of inter-American exchange. It was during his two-year stay in the United States that Destiné made initial contact with the world's leading dancers and choreographers, such as Martha Graham, Katherine Dunham, Pearl Primus, and Sierre-Leonean dancer Asadata Dafora, in order to learn the technical aspects of modern dance. ${ }^{31}$ 
Haitian officials and cultural elites heard about Destinés performances in the United States and were impressed by his ability to garner support and interest in Haitian folkloric dance. Haitian cultural officials asked Destiné to perform in Haiti-stating that the government would only invite "the elite and the educated, not the masses. This is art and you will be able to attract tourists." Destiné served now as an official cultural ambassador. Friends, Haitian politicians, and officials communicated to him that the government needed to send him back to the United States "to make people realize that we [Haitians] have an artist." ${ }^{2}$ By the late 1940s and early 1950s, Haiti's officials concentrated on exporting culture and attracting tourists' foreign capital because it demonstrated Haiti's cultural advancement and produced modest gains in the service economy. At the same time, the ripple effects of tourism placed a significant strain on the country's infrastructure, such as an increased need for electricity, a central water supply, and a sewage disposal system.

By 1946, Destiné returned to the United States with the intent of entertaining and educating American audiences on folkloric dance. Changing U.S. perceptions of African-descended peoples remained critical during the World War II period, when racial discrimination and hegemonic colonial governments in Africa and the Caribbean still reigned. Haiti proved to be a contested space where blackness and indigenous cultural expression battled the prevailing images and stigmas of black primitiveness and inferiority. ${ }^{33}$ Haitian educational institutions such as the Bureau d'Ethnologie in Port-au-Prince attempted to counteract beliefs in black inferiority, particularly concerning the rural black masses of Haiti. While working at Le Nouvelliste, Destiné attended classes at the bureau to learn more about vodou, Haitian folklore, and how the Haitian masses retained aspects of West African traditions. Studying under Jean PriceMars, Destiné remembered that Price-Mars's text Ainsi parla l'oncle (So Spoke the Uncle) became "the first book that started to open our eyes to tell us that we are not of European descent." This book highlighted the syncretic nature of African culture in Haitian life, which propelled many within the Haitian elite to question, "Who are we-Frenchmen or African?" Destiné believed that Haitians were rooted in a West African cultural heritage, even though many of the Haitian elite did not want to believe it.

According to Destiné, some African Americans during the interwar and post-World War II period refused to be associated with African culture; in addition, their knowledge of Haiti was quite limited. ${ }^{34}$ At the same time, black American intellectuals and artists like Katherine Dunham, Langston Hughes, and Paul Robeson proved essential in providing an alternative racial and ideo- 
logical framework of Africa and the Caribbean for many U.S. blacks. Additionally, these individuals advanced Destiné's career to a wider audience. Dunham invited Destiné to become a guest artist in her Broadway production Bal Nègre (1946). Langston Hughes requested him to sing and perform at parties in New York City. When the New York City Opera produced William Grant Still's production Troubled Island, a tragic story about the reign and death of Haitian emperor Jean-Jacques Dessalines, Hughes alerted Still about Destiné's dancing skills. By 1948, Destiné formed his own dance company and performed at a number of sold-out venues. His popularity allowed him to be in a position to entertain and educate American audiences on Haitian culture and also helped him to continue to establish relationships with African American intellectuals and artists.

In 1949, the Haitian government asked Destiné to organize a national dance troupe for its celebration of the bicentennial anniversary of the founding of Port-au-Prince, Haiti's capital city. ${ }^{35}$ La Troupe Folklorique Nationale served as the best publicity for Haiti. Under the leadership of President Dumarsais Estimé, the Bicentennaire Exposition Internationale showcased Haiti's excellence and advancement in cultural arts. Painters, dancers, and musicians played an essential role in inter-American cultural diplomacy. ${ }^{36}$ African American educator and race leader Mary McLeod Bethune's invitation to a presidential ceremony at the bicentennial exhibited Haitian/African American linkages to a common struggle. President Estimé honored Bethune at a "very dignified" ball at the royal palace for her tireless work on the improvement of Haitian education and the lives of Haiti's orphans. ${ }^{37}$ The ceremony organizers called on Destiné, now considered a Haitian cultural ambassador, to perform his heralded Slave Dance. This routine interpreted the evolution of enslaved African descendants from the point of bondage to their physical and psychological emancipation. At the moment of rebellion, Destiné struggled with the chains that imprisoned him and eventually broke free, energetically dancing throughout the ballroom, demonstrating the emergence of a revolution and the beginning of a free black republic.

Bethune seemed to interpret the dancer's breaking of the chains as an action with a very modern relevance. When Destiné severed the chains, Bethune walked over to the fallen chains, picked them up, struggled with them, and broke them again. ${ }^{38}$ This was a significant and symbolic gesture performed in 1949 in front of Haitian and international dignitaries. Racial discriminatory practices, racial violence, and social and economic inequality still plagued Bethune's United States. Bethune's connection with Destiné's Slave Dance ex- 
emplified African American hardship in the United States and echoed the transnational political and cultural engagements between both groups in the post-U.S. occupation era. Destinés artistic vision complemented the Haitian cultural roots of the peasantry and consequently entertained audiences by communicating an art experience that offered cultural awareness of Haitian life. His success served as one of the components that helped bring notoriety and European and American capital to an emerging tourist industry in Haiti.

\section{LAVINIA WILLIAMS AND THE TECHNICAL TRAINING OF HAITIAN DANCERS}

Lavinia Williams's participation in the cultural events of Haiti Week (mentioned at the beginning of this essay) in the spring of 1951 set the stage for her thirty-year relationship with the black republic. During these festivities, Papa Augustin, a Haitian drummer and cultural consultant to Katherine Dunham's dance company, invited Jean Brierre, a poet and director general of the Haitian State Tourist Office, to Lavinia Williams's dance school in Brooklyn, New York. After watching Williams's technique and approach to modern dance, Brierre remarked that it was "the kind of basic technique that I want my people to learn." Within two years, Alphonse Cimber, Haiti's Master of Drums and also Destinés drummer, mentioned to Williams that the Haitian government planned to invite a foreign dance teacher to improve the technical skill of Haitian dancers. Subsequently, with the help of Haitian cultural officials, the Haitian government invited Williams to become a national dance instructor for a period of six months. Excited, Williams wrote to Roger Savain, minister of propaganda, in December 1952, "it has always been one of my fondest ambitions to be given the chance to call upon my dance knowledge, and varied dance background, and present this knowledge to the people of Haiti." ${ }^{39}$

The Haitian government's offer to Williams highlights the question, why did Haitian officials seek out a non-Haitian to teach dance in Haiti? I contend that the Haitian government sought out classically and formally trained modern dancers who brought "technical" and "disciplined" training to Haitian performers. During this period of intensifying Haiti's exposure through tourism and cultural exchange, the Haitian Office of Tourism believed that Lavinia Williams also brought prominence and possibly access to U.S. cultural resources. In April 1957, the Haiti Sun reported, "Haitian artists, until a few years, knew nothing about modern dances, tap dancing or ballet. Now there are hundreds of young people assisted by a French teacher, several Haitian and Ameri- 
can teachers, who are being trained in other forms of the dance." ${ }^{40}$ Williams's dance pedigree, which included several years of experience with Eugene Von Grona's American Negro Ballet (1937-39), Agnes de Mille's production of Obeah (1940), Katherine Dunham's company (1941-45), and Noble Sissle's USO tour of Shuffle Along (1945-46), proved instrumental to her earning the national instructor position and significant to the perception that Haiti, culturally at least, continued to move forward. ${ }^{41}$

Born in Philadelphia, Pennsylvania, Williams's first memories of dance were joyful and painful. She recalled how she gyrated on top of a box at home to impress her family. During the degrading years of Jim Crow segregation, she entered through the back door of a segregated Virginia dance school to take ballet lessons. ${ }^{42}$ Studying ballet in the 1930s, Williams encountered racial discrimination as a young African American woman in a white ballet world. In an interview, she stated, "Being brought up in America you were told you were not supposed to be a ballet dancer because you're black and your behind is too big, and your feet are flat ... I could never get a job in America as [a] black ballet dancer because they took away that part of me, [they] took away my ballet technique and made it modern or acrobatic." ${ }^{33}$ Although Williams finally obtained work in ballet, specifically working in Eugene Von Grona's American Negro Ballet at Harlem's Lafayette Theatre, her statement highlights the prejudice that black dancers encountered with respect to the black female body and African Americans' approach to dance. African-descended dancers could not escape the primitive trope in the dance world, which, in the minds of some blacks, did not necessarily carry a negative connotation. It was often characterized as a source of origin or basic. ${ }^{44}$ Yet ideas on the primitive within the larger North American society and elite dance circles racialized and made inferior notions of primitive dance-images that blacks believed they had to continuously counteract. The description in the 1939 program for the American Negro Ballet perpetuated the belief that black dance was instinctive, simple, and primitive.

The stirring imagination of the Negro and his innate understanding of the fundamental values have left deep, permanent impressions on the arts. In the dance, however, this talent has been confined chiefly to dance-hall jazz and African rituals ... These limited dance forms-while reflecting man's elemental character-have provided no outlet for the deeper and more intellectual resources of the race. In his search for expression the Negro has made several attempts to enter the serious dance but he has been handicapped by economic conditions and the lack of artistic opportunity. ${ }^{45}$ 
Although the quote attributed the marginalization of black dancers to socioeconomic inequalities and the "lack of artistic opportunity," it is also important to note that even the American Negro Ballet deemed "dance-hall jazz and African rituals" as "limited dance forms" and not "serious dance," thus reinforcing hierarchies of cultural forms and the primitive nature of African-descended peoples.

After working with Von Grona's American Negro Ballet from 1937 to 1939, Williams joined Agnes de Mille's production of Obeah in August 1940. It was during this production that Williams acquired an interest in the culture and art of the Caribbean, which Williams asserted was "the missing link to Africa" and one of the roots that many black Americans ignored. Her skill and interest in Caribbean culture(s) made her transition to Katherine Dunham's company in 1941 smooth.

Williams's experience in the Dunham Company profoundly influenced her understanding of dance and the ethnology of dance in countries of African descent. In order to prepare and understand the Dunham technique, Williams noted the importance of understanding an ethnic group's art as a way to better comprehend a people's identity. Participation in a culture and obtaining a socalled authentic knowledge of why people danced and for what purpose proved central to the Dunham technique and Williams's understanding of dance. In her journal, Williams wrote, "Beginners should be well acquainted with the history of primitive peoples ... [and] make a careful study of authentic rhythms in song and dance and of their native costumes and customs." ${ }^{\prime 6}$ Additionally, Williams noted the significance of culture and movement as opposed to imitating it; this was vital to creating a better dance form, to producing a superior theatrical production, and to teaching students how to improve human relations. ${ }^{47}$

Williams's upbringing in the Christian church also facilitated her transition to vodou religion and other Caribbean faiths. Williams, who recalled her grandmother being blessed with healing powers, remembered watching people in church catch "the holy ghost." She maintained that she was drawn to the "Holy Rollers [and] the Sanctified people." 48 These experiences, Williams noted, prepared her for participation and education in vodou and for recognition of the differences between vodou worship and Christian worship. While in Haiti, Williams was possessed three times. In an interview, she remembered her possession experience to be one of elation and clarity.

You are at the peak in your mental approach to who you are, and the cycle goes up —and you come to terms with yourself, mentally, physically, everything. It's like a happy meeting with yourself. But in the U.S. when you get to the height, 
somebody's going to come and say "a heathen" [and] bring you smelling salts because sometimes they pass out. ${ }^{49}$

Williams's early Christian experiences provided her with a space to embrace vodou culture in Haiti. In addition, her participation and possession in vodou rituals carved out a space where she continued to learn and develop folkloric dance and also to realize the significance of being free of restraint or social judgment.

Discriminating opinions from friends surfaced when Williams decided to accept the teaching position in Haiti. Some of her friends commented, "Well, you want to go to the West Indies, that's like taking coals to Newcastle. They [West Indians] already know how to shake." 50 Common racial/ethnic stereotypes regarding African-descended peoples and their "intuitive" knowledge of dance persisted within U.S. cultural spaces, as in the American Negro Ballet's 1939 program description and Destinés early perceptions about African Americans. Williams, as well as other dancers and participants in vodou and folkloric dance, emphasized the tremendous amount of training and practice involved in dance performance. To such misinformed assertions, she responded, "It's not shaking that's important ... There is a discipline to knowing how to shake, that is important." Furthermore, Williams argued, "I know when I analyze the shoulder movements, for instance, it is like mathematics. Everything is according to music. The African and West Indian beat is so technical, that you can't just get up and do anything." ${ }^{11}$ Thus, Williams's formal training, her association with Dunham's company, and her extensive international travel shaped her into an ideal candidate for Haitian officials.

On April 23, 1953, she arrived in Haiti with her two daughters and was met by a committee of Haitian delegates, including Emerante de Pradines, a popular Haitian singer. ${ }^{52}$ Her technical responsibilities included dance instruction at the Lycée des Jeune Filles, training several teachers from the Bureau of Sports, offering physical culture classes and body conditioning exercises to the members of La Troupe Folklorique Nationale, and also acting as a special instructor to the troupe. Claude Barnett, founder of the Associated Negro Press, reported that Williams's "technical skill" facilitated the development of Haitian potential in the field of dance. He asserted:

What Miss Williams has done, of course, is to establish a systematic pattern for developing the Haitian potential for basic African dances; a potential that has long been a part of the island's culture, by applying technical skill; a sort of 
blending of the cultures of the two countries in one art form ... The ballet, voodoo dancing, the Latin rhythms and acrobatic dancing, as developed to a high degree on the American stage, have all been fused into what has come to be regarded as the Afro-Haitian dance. ${ }^{53}$

The Haitian government and African American leaders like Barnett maintained that Haitian dancers needed technical training in order to advance and attract tourists and modernize aspects of Haitian culture.

In fact, during this era of post-World War II development, the social, political, and economic aspects of Caribbean and Latin American societies were entrenched within a language of modernization. Modernization was often defined by a nation's ability to move progressively forward in technological and industrial development. It also encompassed cultural arenas, particularly dance and art in the Caribbean. Vodou-inspired folkloric dance, rooted in the cultural memory and modern experience of racial slavery and New World cultural syncretism, underwent a calculated transformation by black dancers and choreographers that required classification, disciplining, and packaging so that it could be shared with the modern world through formal dance instruction, Africanbased cultural awareness, and tourist entertainment. Rex Nettleford, a noted dance scholar, encouraged the "systematisation" of dance knowledge and history in order to build a "sound technique." Nettleford's ideas about the disciplining of Caribbean dance articulated the transmission of an Afro-modern consciousness made possible through sharing of cultural information, history, and talents among African-descended peoples in the Americas. ${ }^{54}$

In November 1954, Williams founded the Haitian Academy of Folklore and Classic Dance (HAFCD), a manifestation of the classification of Haitian dance. The academy married modern dance, classical ballet, and secular Haitian dance in order to create an innovative Haitian folkloric dance tradition. Williams sought to "carry [the] 'dance of the people' beyond its present 'accepted' stage and develop it so that it can be interpreted, classified and appreciated by all students of the dance and art lovers in general. ${ }^{55}$ HAFCD offered courses in ballet, choreography, and folkloric dance, each performing a particular function in the development of the modern Haitian dancer. Ballet, as stated in Williams's text Haiti Dance, operated as the classic foundation of dance, a universal language that conveyed a "mastery of body mechanics to increase the grammar and vocabulary of the dance for individual students." ${ }^{56}$ Trained Haitian choreographers, well-versed in the technique and methods of Martha Graham and Louis Horst and the "movement and exercises from ... Katherine Dunham, 
Michael Kidd, Helen Tamaris [and] Kyra Nijinsky," created new designs and modifications to sacred dance. Finally, the study of folkloric dance provided an understanding of the form and function of vodou dance and song and also its relationship to Haitian history.

For Williams and associated Haitian officials it was not simply a matter of incorporating European forms and exercises into Haitian dance in order to legitimize it or the cultural modernity of Haiti. Similar to the Bureau d'Ethnologie, which utilized European scholarship, the HAFCD served as an educational institution whose objective was to establish the significance and to promote the historical and cultural traditions of the Haitian masses. Nevertheless, Haitian sacred culture was being transformed-demonstrating the malleability and fluidity of a culture whose existence was being threatened by Haitian antisuperstitious laws. Subsequently, the academy created culturally astute dancersor, rather, ambassadors-for Haiti. Régine Mont-Rosier, an advanced ballet student at the academy, became one of Haiti's cultural ambassadors during the late 1950s, when she earned a scholarship to Ballet Arts at Carnegie Hall in New York City. Mont-Rosier's significant press in Haiti demonstrated not only Williams's success as an instructor but also Haiti's production of another potential artist. ${ }^{57}$

Williams's technical training and her relative fame as an American dancer proved to be a perfect match for Haiti. With the full support of the Haitian government, Williams became a central figure in tourist and socially elite circles. Williams broadcasted Glimpses of Haiti, her radio program, three nights a week in order to expose and educate tourists to the richness of Haitian history and culture. ${ }^{58}$ The national and international popularity of Haitian folkloric dance, coupled with the growing reputation of Haitian "primitive" art, created a sense of national pride for many Haitians, even among some Haitian elite, who typically shunned the cultural production of the masses. According to Gérarde Magloire and Kevin Yelvington, "folklore had been made to serve nationalist movements," and similar to the ways it was utilized in the texts of Jean PriceMars during the violent years of U.S. occupation, folklore was being resurrected to complement the perception of President Magloire's noirisme and also to build nationalist fervor in favor of the government's modernist projects. ${ }^{59}$ Williams's training in ballet bridged a gap between participating elites, the black middle class, and the masses. Although Williams explained that she initially received the most resistance from Haitian elites, who claimed "ballet belonged to [them]" or that their children were forbidden to dance folklore, the dance institutions allowed children of varying classes to interact in later years 
and introduced the Haitian masses to ballet as well as to the secular danse folklorique.

It is clear that Williams envisioned Haiti as a potential center of black cultural production in which "people could come from all over the world for study, and for rhythmical inspiration." In July 1954, Williams asserted that with the cooperation of the Haitian government and its people, "not only will a new group of tourists be coming to Haiti, but they can help us to realize an establishment which may someday incorporate not only dancing, but music, painting, drama, opera, and all of the other related subjects to help found a University of 'Beaux Arts of Haiti.'" 60 Institution building and social and economic development through cultural exchange, tourism, and an effective promotion of racial and cultural identity proved to be the manifestation of her internationalist ideals. The Haiti Sun reported that Williams was not only "developing choirs and cultivating the voices of the young Haitian" but also giving Haitians "an appreciation and a pride for their national art." ${ }^{\prime 1}$

Lavinia Williams spent the next several decades in Haiti and other countries of the Caribbean, teaching, dancing, and embracing Haitian culture. Indeed, it was a source of spiritual inspiration and creative fulfillment. When she heard the drumbeats in Haiti, which she deemed the "heartbeat in the bosom of Mother Africa ... that mediates you from the unknown to the known," she knew she belonged there. ${ }^{62}$ Her dance pedagogy sought to bring recognition to Haiti's shores and also to complement the work of the Bureau d'Ethnologie by educating many Haitian dancers on the form and function of Haitian folkloric dance so as to enrich their understanding and appreciation of Haitian and West African culture. She claimed that renowned dancer Isadora Duncan accomplished the same type of work: "She discovered modern dance and went all through Europe and Russia, and she sort of said that there's another way of doing things. And I've said the same thing with my black people."63

\section{CONCLUSION}

For Destiné and Williams, dance was indeed a form of entertainment. However, the art of these dancers possessed larger social and political implications that meant considerably more to them and Haitians than pure amusement. By advancing vodou-inspired Haitian culture, these dancers made a bold statement against an incredibly class-conscious Haitian society that ignored and demeaned art forms possessing peasant origins. These artists understood that creativity could be used as currency to aid in the advancement of Haitian na- 
tional identity and possibly further develop cultural pride and consciousness in the African diaspora. The popularity and evolving representation of Haitian folkloric arts operated as one of the means to address challenges to modern development in Haiti.

The activities of these Afro-modern dancers proved significant because these endeavors utilized the realities of antiblack and antipeasantry prejudices to advance a black internationalist consciousness and because they served as a means to develop Haiti through tourism and cultural redemption during the postoccupation period. The fusion of dynamic "folk" customs and "modern" ingredients were not contradictory but affirmed the culturally redemptive histories and experiences of African-descended peoples with Western dance forms, institutions, and discourses in order to produce new ideas, organizations, and conversations. ${ }^{64}$ With the international recognition of Haitian art forms, Haitian folkloric dancing was one way to articulate Haiti's right to participate in inter-American and global affairs.

\section{Notes}

1. News of Haiti, March 15, 1951, in Claude Barnett Papers, box 203, General Correspondence folder, 1951-54. The opening of the Haiti Tourist Information Bureau, an official government agency, at Rockefeller Plaza in New York coincided with the commencement of Haiti Week events.

2. News of Haiti, March 15, 1951, in Claude Barnett Papers, box 203, General Correspondence folder, 1951-54.

3. For more critical responses to U.S. Pan-Americanism, see Millery Polyné, From Douglass to Duvalier; Sheinin, Beyond the Idea; Aguilar, Pan Americanism; Ramirez Novoa, La Farsa del Panamericanismo; Martínez, De Bolivar a Dulles.

4. Plummer, Haiti and the United States, 137.

5. On March 15, 1951, News of Haiti reported the building of fifteen industrial centers throughout Haiti and the paving of new asphalt roads. Also, it informed readers of President Magloire's "New Deal" in Haiti, where "155 one and two-family dwellings" would be built in St. Martin Delmas, a suburb of Port-au-Prince. Scholar Michel-Rolph Trouillot asserts that Haiti became a nation of "projects" between 1946 and 1956 but that these development ventures, programs, and economic missions served only as an illusion of progress (Haiti: State against Nation, 140).

6. Cuba, Jamaica, the Dominican Republic, the Bahamas, and Puerto Rico were some of the islands that supported tourism as early as the 1930s. See Schwartz, Pleasure Island, 108-9. Also see Ramsey, "Without One Ritual Note."

7. The quote is from a comment made by Dr. Cary Fraser at the Association for the Study of African American Life and History Conference, October 1, 2004.

8. Magloire and Yelvington, "Haiti and the Anthropological Imagination," 146. 
9. Ibid.

10. Sibylle Fischer's work on the "disavowal" of Afro-Cuban art during the Age of Revolution proves to be significant to understanding the contributions of art to modernization. Fischer argues that art- "both visual and literary" (and I would add performative art)—and its representation "is part of modernization" and that "to the extent that modernization makes the environment representable, it is part of an artistic process; it is almost as if perspective were as much a quality of the world as of its representation" (Modernity Disavowed, 76).

11. For more information on the "golden age of tourism," read "Le Vogue Nègre" in Plummer, Haiti and the United States, 123-38.

12. Walter White, executive secretary of the NAACP, and his wife, Poppy Cannon, organized and implemented a detailed public relations campaign for Haiti in the late $1940 \mathrm{~s}$ through the mid-1950s. White and Cannon, in conjunction with the Haitian government, dedicated themselves to change the image of Haiti and transform it into an economically viable and tourist-friendly destination.

13. According to a 1959 souvenir book and shopping guide entitled Joie de Vivre en Haïti, four major hotels, including the Casino International, Hotel Castel Haiti, Hotel Ibo Lele, and Hotel Riviera, all held evening dance shows-in some places as much as two or three times a night. Souvenir book is in author's possession.

14. Ibo Lele is a nation of divinities remembered with a seven-mouthed pot. Shango is considered to be the god of thunder. See Consentino, Sacred Arts of Haitian Vodou.

15. Ramsey, "Without One Ritual Note," 11. Refer also to Kate Ramsey, "Prohibition, Persecution, Performance," 165-79.

16. Ramsey, "Without One Ritual Note," 13.

17. Destiné, interview.

18. Trouillot, Haiti: State against Nation, 115.

19. Destiné, interview.

20. Dunham, Island Possessed, 3.

21. Ibid. (my italics).

22. The influence of Lina Fussman-Mathon—or Lina Blanchet, as many knew her before her second marriage-cannot be understated. It is critical that more research be done on her artistic career in Haiti.

23. Destiné, interview.

24. For more information on the events and controversies leading up to and after the National Folk Festival, see Ramsey, "Without One Ritual Note," 7-42.

25. Destiné, interview.

26. Nouvelle cooperation was a term President Sténio Vincent used during the postoccupation period. It designated a new independent Haiti and the formation of an egalitarian partnership between Haiti and the United States along economic, political, and cultural lines. See Verna, Haiti's "Second Independence."

27. Rayford Whittingham Logan Papers, box 3, Personal Diary 1941 folder. At a luncheon with Maurice Dartigue (a Haitian educator), Richard Pattee, and Charles Thompson (chief of the Division of Cultural Relations in the U.S. State Department), Logan was optimistic about the development of inter-American cultural relations because Pattee and Thompson were "very liberal." 
28. Robert G. Caldwell to Walter White, October 7, 1940, NAACP Papers, Group II, box A 609, folder 5, General Office File Good Neighbor Policy. See also, in the same collection, Walter White to Sue Thurman, September 10, 1940; Walter White to Nelson Rockefeller, October 4, 1940.

29. See Hanson, Cultural-Cooperation Program; U.S. State Department, Program of the Interdepartmental Committee; Trueblood, U.S. Cultural Relations Program. At the local level, African Americans, Caribbeans, and a few liberal whites in the United States believed in the importance of informing the American public about two main issues in the context of inter-American affairs: first, there existed a significant population of Africandescended peoples in Latin America and the Caribbean; second, their struggles and achievements proved important to the success of race relations in the United States and of Pan-Americanism.

30. See Berman, Carnegie, Ford, and Rockefeller Foundations; Cueto, Missionaries of Science.

31. Destiné, interview. Interestingly, during Destiné's scholarship period, he picked up the name Jean. Destiné's original name is Léon Destiné, but he added Jean since he performed considerably and did not want the scholarship committee to hear about his extracurricular activities and possibly think that he was not fulfilling his academic duties.

32. Destiné, interview.

33. For a better understanding of Western perceptions of Haiti and its people, see Dash, Haiti and the United States.

34. Destiné's opinions about African American consciousness of Africa and black history in the Americas are valid. However, it is important to note the rich history on African American anticolonialism in Africa and the Caribbean. See the growing literature on African Americans and U.S. foreign policy in the twentieth century, including Plummer, Rising Wind; Von Eshen, Race against Empire; and Dudziak, Cold War Civil Rights.

35. Destiné assembled La Troupe Folklorique Nationale with dancers through Lina Fussman-Mathon. La Troupe Folklorique also had a fifteen-piece orchestra named Jazz de Jeune, three drummers, and several singers. According to Destiné, many Haitian dance teachers were upset with him because he visited Haiti sparingly and could recruit dancers away from Haitian teachers, possibly leaving them unemployed.

36. Americans and the U.S. government were invited and also participated in the bicentennial events. The Haitian government invited President Harry S. Truman and Eleanor Roosevelt as guests to the exposition (although they did not attend), and the U.S. Congress established a commission known as the United States International Exposition for the Bicentennial of the Founding of Port-au-Prince. See Pamphile, Haitians and African Americans, 153.

37. See Mary McLeod Bethune to Arabella Denniston, July 29, 1949, Mary McLeod Bethune Papers.

38. Destiné, interview.

39. Lavinia Williams to Roger Savain, December 2, 1952, Lavinia Williams Collection, box 2, Miscellaneous Letters folder (hereafter, the Williams Collection is cited as LWC). Roger E. Savain wrote Williams back, stating that Williams would also be "the 
special instructor of the National Folklore Troupe of Haiti." "In addition to that," he explained, "the Department of National Education will guarantee you \$50.00 a month, and it would like you to teach plastic dance only to the girls in one Lyceum and one Normal School" (Roger E. Savain to Lavinia Williams, January 22, 1953, LWC, box 2, Correspondence Letters Received, 1952-71).

40. Haiti Sun, April 21, 1957.

41. Lois Wilcken asserted that during Paul Magloire's presidency, Haitian intellectuals "expressed the need to temper Afro-Haitian dance with the aesthetic standards of ballet and modern dance" ("Spirit Unbound," 116).

42. Murray, interview.

43. Lavinia Williams, interview with Annette McDonald, LWC, box 1.

44. Destiné, interview. See also Torgovnick, Gone Primitive; Lemke, Primitivist Modernism.

45. Lavinia Williams, interview with Annette McDonald, LWC, box 1.

46. LWC, box 1, 1942-45 folder. Williams was still working for and learning from Katherine Dunham at this time.

47. The Dunham School and Dunham's company institutionalized this ethnological technique and aimed to provide a well-rounded education for its students. In January 1946, Dunham wrote to Williams discussing the expansion of the Dunham School in New York to include theater courses and cultural courses such as acting, elementary French, and general anthropology. Dunham wanted to give students "every chance to become equipped for the human race" (Katherine Dunham to Lavinia Williams, January 17, 1946, LWC, box 10, Katherine Dunham folder).

48. Lavinia Williams, interview with Annette McDonald, LWC, box 1.

49. Ibid. According to Williams, she participated in vodou ceremonies at least once or twice a month.

50. Lavinia Williams, interview with Annette McDonald, LWC, box 1.

51. Ibid.

52. Williams Yarborough, "Haiti," 42.

53. Undated newspaper clipping, "American Contribution to Haitian Culture: Dancer Making History as Director of Haitian Institute of Folklore and Classical Dance," LWC, box 2, Letters Received, 1952-71.

54. LWC, box 19, Printed Matter-Caribbean Dance folder. Lavinia Williams proceeded to teach Haitian folkloric dance, ballet, modern dance, and other Caribbean forms of dance in Jamaica, Guyana, and the Bahamas. See "American Teaches Haitian Dances."

55. Williams, Haiti Dance, 35.

56. Ibid.

57. LWC, box 4, Regine Montrosier folder.

58. Many of these programs were rebroadcast on Chicago radio stations, presumably because of her close relationship with Claude Barnett and his wife, Etta Moten Barnett, who were based out of Chicago, Illinois. Etta Moten Barnett hosted her own radio show in Chicago and, at times, broadcasted her show from Haiti.

59. Magloire and Yelvington, "Haiti and the Anthropological Imagination," 132.

6o. Haiti Sun, July 25, 1954. 
61. Haiti Sun, no date, LWC, box 4, Regine Montrosier folder.

62. Lavinia Williams, interview with Annette McDonald, LWC, box 1.

63. Ibid.

64. See Hanchard, "Afro-Modernity," 245-68.

\section{Bibliography}

Aguilar, Alonso. Pan Americanism from Monroe to the Present. New York: Monthly Review Press, 1968.

"American Teaches Haitian Dances to Jamaicans." Jet Magazine, October 2, 1958.

Berman, Edward. The Influence of the Carnegie, Ford and Rockefeller Foundations on American Foreign Policy: The Ideology of Philanthropy. Albany: State University of New York Press, 1983.

Claude Barnett Papers. Chicago Historical Society, Chicago.

Consentino, Donald J., ed. Sacred Arts of Haitian Vodou. Los Angeles: University of California at Los Angeles and The Regents of University of California, 1995.

Cueto, Marcos, ed. Missionaries of Science: The Rockefeller Foundation and Latin America. Bloomington: Indiana University Press, 1994.

Dash, J. Michael. Haiti and the United States: National Stereotypes and the Literary Imagination. New York: St. Martin's Press, 1997.

Destiné, Jean Léon. Interview with the author, July 9, 2002, Harlem, New York City.

Dudziak, Mary L. Cold War Civil Rights: Race and the Image of American Democracy. Princeton: Princeton University Press, 2002.

Dunham, Katherine. Island Possessed. 1969. Reprint, Chicago: The University of Chicago Press, 1994.

Fischer, Sibylle. Modernity Disavowed: Haiti and the Cultures of Slavery in the Age of Revolution. Durham: Duke University Press, 2004.

Hanchard, Michael. "Afro-Modernity: Temporality, Politics, and the African Diaspora." Public Culture 11 (Winter 1999): 245-68.

Hanson, Haldore E. The Cultural-Cooperation Program, 1938-1943. Washington, DC: U.S. Government Printing Office, 1944.

Lavinia Williams Collection. Schomburg Center for Research in Black Culture, New York, New York.

Lemke, Sieglinde. Primitivist Modernism: Black Culture and the Origins of Transatlantic Modernism. New York: Oxford University Press, 1998.

Magloire, Gérarde, and Kevin A. Yelvington. "Haiti and the Anthropological Imagination." Gradhiva 1 (2005): 127-52.

Martínez, Ricardo. De Bolívar a Dulles: El Panamericanismo Doctrina y Práctica Imperialista. Mexico City: Editorial América Nueva, 1959.

Mary McLeod Bethune Papers. Library of Congress, Washington, DC.

Murray, James Brigg. Interview, October 1983. Sound Division, Schomburg Center for Research in Black Culture, New York, New York.

NAACP Papers. Library of Congress, Washington, DC.

Pamphile, Léon D. Haitians and African Americans: A Heritage of Tragedy and Hope. Gainesville: University Press of Florida, 2001. 
Plummer, Brenda G. Haiti and the United States: The Psychological Moment. Athens: University of Georgia Press, 1992.

Plummer, Brenda G. Rising Wind: Black Americans and U.S. Foreign Affairs, 1935-1960. Chapel Hill: University of North Carolina Press, 1996.

Polyné, Millery. From Douglass to Duvalier: U.S. African Americans, Haiti, and Pan Americanism, 1870-1964. Gainesville: University Press of Florida, 2010.

Ramírez Novoa, Ezequiel. La Farsa del Panamericanismo y la Unidad Indoamericana. Buenos Aires: Editorial Indoamérica, 1955.

Ramsey, Kate. "Prohibition, Persecution, Performance: Anthropology and the Penalization of Vodou in Mid-2oth Century Haiti." Gradhiva 1 (2005): 165-79.

Ramsey, Kate. "Without One Ritual Note: Folklore Performance and the Haitian State, 1935-1946." Radical History Review 84 (Fall 2002): 7-42.

Rayford Whittingham Logan Papers. Manuscript Division, Library of Congress, Washington, DC.

Schwartz, Rosalie. Pleasure Island: Tourism and Temptation in Cuba. Lincoln: University of Nebraska Press, 1997.

Sheinin, David, ed. Beyond the Ideal: Pan Americanism in Inter-American Affairs. Westport, CT: Praeger, 2000.

Torgovnick, Marianna. Gone Primitive: Savage Intellect, Modern Lives. Chicago: University of Chicago Press, 1991.

Trouillot, Michel-Rolph. Haiti-State against Nation: Origins and Legacy of Duvalierism. New York: Monthly Review Press, 1990.

Trueblood, Edward Gatewood. The U.S. Cultural Relations Program with Latin America: The Formative Years. Gainesville: Felicity Press, 1977.

U.S. State Department Office of Public Affairs. The Program of the Interdepartmental Committee on Scientific and Cultural Cooperation. Washington, DC: U.S. Government Printing Office, 1944.

Verna, Chantalle F. 'Haiti's 'Second Independence': The Pursuits and Challenges of Haiti/U.S. Cooperation, 1934-1957.” PhD diss., Michigan State University, 2005.

Von Eshen, Penny. Race against Empire: Black Americans and Anticolonialism, 1937-1957. Ithaca: Cornell University Press, 1997.

Wilcken, Lois E. "Spirit Unbound: New Approaches to the Performance of Haitian Folklore.” In Caribbean Dance from Abakuá to Zouk: How Movement Shapes Identity, edited by Susanna Sloat, 114-23. Gainesville: University Press of Florida, 2002.

Williams, Lavinia. Haiti Dance. Frankfurt: Bronners Druckerei, 1959.

Williams Yarborough, Lavinia. "Haiti: Where I Teach and Dance." Dance Magazine (October 1956): 42. 

PART THREE: CONTEMPORARY MUSIC 



\section{Motherland Hip-Hop: Connective Marginality and African American Youth Culture in Senegal and Kenya}

\section{HALIFU OS UMARE}

On October 8, 2006, an important event in the evolution of African hip-hop took place in the Cargo Club in London, England. It was an African hip-hop festival called "Afrolution," featuring hip-hop music groups from five different countries_-Zimbabwe, Malawi, Kenya, Gambia, and South Africa. Produced by Afrolution Records, this festival represented the growing face of African rap music and hip-hop culture that has taken root in each country on the African continent, continuing a kind of cultural revolution that adapts and extends this received African American youth culture. Simultaneously, African hip-hop culture facilitates connections across nation-states, languages, cultures, and ethnic groups that have been often divided and in conflict. African hip-hop youth find that they have more in common than they have differences, offering a potential ameliorating force for some of Africa's long-standing problems. Festivals like Afrolution happen not only in Europe but on the African continent as well, such as the annual Gabao Hip-Hop Festival in Gabon. These festivals, whether in Africa or Europe, provide forums for youth from different African cultures to find a common voice for similar issues and concerns, linking youth on the vast African continent through rhymes, beats, dance moves, rebellious attitude, and particularized social critiques.

The youth subculture of hip-hop is a way of life that consists not just of the more pervasive element of rap music production and dissemination but also of deejay turntabling-mixing-producing; the daredevil acrobatics of b-boying and b-girling (dubbed by the media "break dancing"); the more recent rap 
dancing that accompanies today's rap music videos; aerosol "graf" art, or graffiti; and a general style, dress, and attitude about the world. The latter element of attitude is most important, because it is precisely this element, along with the obvious commodification of the subculture by American capitalism, that is most responsible for it proliferating from the South Bronx starting in the mid-1970s to nearly every continent, country, culture, and ethnic group on the planet, including Africa. The attitude of "flippin' the script"—or talking back to any system of marginalization, whether based on race, ethnicity, nationality, class, politics, neighborhood, or gender-posits hip-hop as a complex subculture not easily dismissed as a new fad that would dissipate, as the media pundits once pronounced in the mid-1980s about its then initial national commercialization in the United States.

Most youths globally seem to identify with this hip-hop attitude of "flippin' the script," offering alternatives to the master narrative prevalent in each particular locality. They also view the subculture's defiance as a unifying force across borders and governments. Hip-hop organizational Web sites, e-zines, and international b-boy competitions virtually and physically link hip-hop youth throughout the world into the concept of the "Hip-Hop Globe." This is a construct that is gaining increasing currency as young hip-hoppers grow up, become professionals, and link together across continents to accomplish various artistic projects.

Hip-hop in Africa (and outside of the United States generally) usually emphasizes the importance of counterhegemonic messages, one of the original penchants of the youth culture that has been obscured by its commercial "bling-bling" success in America. In South Africa, a crew called "Cashless Society" stands in literal and metaphoric contrast to Atlanta's Cash Money Crew in the United States. Cashless Society's name alludes to the realities of their situation as black South Africans in postapartheid Johannesburg, as opposed to the flaunting of money, diamond jewelry, and cars with twenty-five-inch rims sported by Cash Money Crew and many other commercial U.S. rappers. African hip-hop may offer a much needed alternative to hip-hop's near total usurpation by the U.S. multinational record industry and American capitalism. This essay is an exploration of these dynamics in African hip-hop, grounded in one popular rap crew in Kenya, with a brief discussion of a Senegalese group for contrast. In exploring the dynamics of why hip-hop resonates in Africa, I also engage my theory of connective marginality that I fully elucidate in The Africanist Aesthetic in Global Hip-Hop: Power Moves (2007). Connective marginalities of culture, class, historical oppression, and youth itself complicate the 
more familiar explanation of American popular cultural imperialism and its perceived wholesale adoption by youth globally.

\section{CONNECTIVE MARGINALITIES IN THE HIP-HOP GLOBE}

Imagine U.S. African American and Latino hip-hop culture at the center of a circle that has larger concentric circles emanating from it, each representing various sociohistorical realms that facilitate, inform, and motivate youth globally. These concentric, interrelating circles of influence are what I call "connective marginalities." 1 The generational connection of "youth" itself, as a marginal status in most societies, is the easiest connection represented by the largest outer circle. Often, the younger, coming-of-age generation in each society is in conflict with the adult population in control of various realms from government to social norms and rules of conduct. Youth rebelliousness becomes a natural aspect of this age-group, making hip-hop's rebellious tenets extremely alluring. Many nations, like Japan and Russia, connect with hip-hop simply because of its youthful rebellion.

Class is the second-largest social sphere of connectivity; worldwide, many ethnic and immigrant groups, perceived as either not indigenous or simply historically inferior in a particular society, are often relegated to second-class citizenship that results in a marginalized status. For youths among these "lowerclass" groups in various countries, hip-hop becomes a way of giving voice to their unrest. Class status is measured in financial wealth, political power, and family position in most societies; it is often inherited but sometimes ascribed through mechanisms of social mobility. For whole populations who have been assigned a lower social status in a particular society, it becomes difficult, if not next to impossible, to alter that status. Hip-hop's many rags-to-riches tales of wealthy rappers who were once ghetto dwellers are stories circumscribed by U.S. dynamics as the richest country in the world. In other nations, such as certain African countries, rap artists and hip-hop consumers coming from classmarginalized groups do not have that same social mobility. North African Arabs living in France, for example, are first-, second-, and third-generation immigrants from France's colonial empire. In 2005, it was precisely these youth who were the source of the social unrest in France.

Historical oppression and culture are the last two connective marginalities that help explain hip-hop's internationalization. Historical oppression, as the third-largest circle, explains the social status of a group who identifies with a long history of purposeful subjugation-one that can identify with the African 
American experience as a prototypical model of overt oppression over centuries, such as American Indians or Native Hawaiians or black South Africans. Culture, too, becomes an important resonance in global hip-hop. If a youth culture, like that on the African continent, comes from a society steeped in an Africanist aesthetic - that is, in artistic elements such as polyrhythm, call-andresponse, multiple meters, dance movements that privilege body isolations, and general improvisational skills, all posited within a battling/competitive mode that promotes energy as a vital force-then there will be cultural connections to the hip-hop aesthetic. This aesthetic has often been denigrated throughout the Americas as "low art," as opposed to the "high art" of Europe. The Africanist aesthetic has indeed been marginalized, even though it has been the underpinning of world popular music and dance. ${ }^{2}$

Hip-hop culture is the latest manifestation of this aesthetic that was transported throughout the Americas during the Atlantic slave trade. All of these artistic elements resonate with cultures where the Africanist aesthetic is also very prevalent. African countries become important sites where local youth view connections between hip-hop and their rhythms exported long ago, as well as oral traditions like the West African griots, as a shared history with the black Atlantic. The aesthetic-cultural connection gets overlaid with class and youth rebellion in the African urban ghetto context. In Africa, youths connect with hip-hop as an aesthetic returned home and feel very comfortable with its elements, including its penchant to "flip the script" and challenge the local status quo. My construct of connective marginality adds new dimensions to the debate about global American cultural imperialism in general, particularly on the African continent. The connections perceived by youth themselves mitigate the profit motive of global pop cultural industries such as MTV Africa and the international subsidiaries of the major record companies.

In Popular Music and Youth Culture (200o), British pop music scholar Andy Bennett examines dimensions of the global-local problematic inherent in the exportation of Western pop music to the rest of the world. Obviously, the biggest problem in dealing with popular music is the issue of "how to reconcile popular music's position in the marketplace with its function as a potentially counter-hegemonic cultural resource." ${ }^{3}$ Contrary to many of the early scholars in the field of cultural studies, scholars like Bennett analyze local agency as an important aspect of popular music consumption. According to Bennett, the local audience for popular music "becomes a discursive trope signifying the constantly shifting and radically heterogeneous ways in which meaning is constructed and contested in multiple everyday contexts of media use and 
consumption." ${ }^{4}$ In other words, the audience, as representative of the local values receiving the global commodity of U.S. rap music, can alternate back and forth in assigning meaning and value to this particular style of music. Bennett's further analysis of the significance of locality and particularity in this era of the massive exportation of American popular music validates my focus on agency implicit in hip-hop's connective marginalities. He notes, "Far from destroying local differences between national and regional cultures, globalization may in fact work to enhance such differences." ${ }^{5}$ He goes on to use media scholar James Lull's concept of "reterritorialization," where global commodities are reworked by local audiences to incorporate them into everyday local settings and, in the case of rap music, to critique particular social and cultural dynamics of their country. Viewing specific African localities illuminates connective marginalities and Bennett's use of reterritorialization.

\section{AFRICANHIPHOP.COM}

American popular culture hegemony ensured hip-hop music's popularity in Africa since the early 1980s. South Africa's wealth and connections to Europe made it one of the first to produce a recognized African hip-hop group-Black Noise, a crew from Cape Town, South Africa. They began as a graffiti and break-dance crew and started emceeing around 1989. South Africa's apartheid government initially tried to ban rap music due to its involvement in the struggle against the racist regime, speaking volumes about hip-hop's connective marginality of historical oppression. Thus hip-hop's tendency toward "flippin' the script" of the social order was a part of the culture's early inroads on the African continent, giving voice to youth participation in the antiapartheid movement. The South African government did not make hip-hop legal until 1993, when rap music began to be played on radio and when rap videos appeared on television. Its legalization has resulted in today's Channel O in South Africa as a hip-hop music video station complete with black celebrity veejays. During the late 1980 and early 1990s, hip-hop culture escalated all over Africa, each region privileging its own rhythmic style of rap, often in indigenous languages and musical rhythms. ${ }^{6}$

Today, the Internet serves as an important tool in facilitating hip-hop's unification process of local African youth cultures. One important Web site was originally known as "Rumba Kali-The Home of African Hip-Hop" and is currently called "Africanhiphop.com: The Foundation of African Hip-Hop Culture Online." That this community of African hip-hoppers is located on the 
World Wide Web, linking the primary sites of Dakar, Cape Town, Accra, Lagos, Dar es Salaam, and Nairobi, is indicative of the postmodern era where new global technologies coalesce with the long-standing need for African unity. Many hip-hop youths in Africa have transcended traditional rivalries of regionalism and tribalism and coalesced around common concerns through an artistic expression that originated in the African diaspora, a point to which I will return later in exploring Kenyan rap. Africanhiphop.com, as a hip-hop "zine," projects a fully democratized image of shifting voices from the various locations on the continent. One of the primary features of the home page of the Web site is its hyperlinked map of Africa, where one can click on any country to get the latest news about that site's hip-hop scene, often complete with downloads of rap artists' current hits.

Early on, Africanhiphop.com set its agenda for creating connections and collaborations on the continent and across the black Atlantic. A June 1998 theme for the Web site's home page was "Africa-Wake Up \& Unify." Rap crews from six African countries were invited to contribute their rhymes on that theme, often in their indigenous languages. Not only was African unity served, but Africa's connection to the roots of hip-hop in African American culture was declared. This latter point is implicit in any culture's participation in the global hip-hop youth phenomenon but is not always directly acknowledged. "AfricaWake Up \& Unify" also included American rappers KRS-One and Busta Rhymes, as two of the culture's "elders" from the United States. The site read, "With artists from six African countries and one verse contributed by KRSOne, we come full circle." The site also provided a link that month to American "old school tracks," described as "the oldies of which date back to 1983 !"”

This conscious use of hip-hop to create black Atlantic musical links continues in contemporary times. In August 2006, the Web site used the digital revolution, broadcasting over five hours of contemporary hip-hop via "African HipHop Radio." In December 2006, the Web site had a webcast of one of its bimonthly forums, called "The Satanic Verses versus the African Dilemma," hosted by deejays Drew and J4. The issues discussed via the webcast were listed as follows:

Bling Bling versus Pan Africanist, Revolutionary versus Terrorist, and Conscious versus Commercial: in 2006, African hip-hop artists are facing more dilemmas than ever before. What are the choices that they have to deal with in their careers, and which factors influence their decisions in the context of a globalizing and polarizing world? ${ }^{8}$ 
In the computer age, African youth are linking the continent through hip-hop in ways that their parents could have never dreamed, as well as tackling issues that are both local and global, while positioning their youth culture in the international marketplace of popular culture and attendant ideologies. In so doing, they interrogate their particular concerns in relation to the larger context of global capital generated by hip-hop youth culture.

This technological facilitation of African unity through hip-hop youth does not, however, negate international pop culture industry and technological hierarchies. Hip-hop culture takes its place within the larger context of Africa's neocolonialist umbilical cord, linking the continent to the Western-dominated media for news and popular taste. Although Africanhiphop.com is definitely pro-African and has served a salutary purpose since 1997, many of its literary contributors and critics are Europeans who either travel back and forth to Africa or live there. Malian film scholar Manthia Diawara observes that the global media "wired Africa to the West, ... to the extent that Africans are isolated from nation to nation, but united in looking toward Europe and America for the latest news, politics and culture."9 Even though the World Wide Web has ameliorated this dynamic to a degree by linking community to community and people to people, aspiring African hip-hop emcees are still in competition with the hegemony of American music promoted by the global pop culture media. African American rhythm and blues and jazz that influenced their parents' and grandparents' generations often dominate the airwaves. Indigenous rap music is only beginning to get mainstream radio airplay in most of Africa's urban centers, and when it does, American stars like Jay- $Z$ and Diddy are more likely to be featured than their own local rappers. Cultural resonances across Africa and its diaspora through hip-hop subculture are manifest within continuing international hierarchies and exigencies of global capital.

Yet even with the realities of these hegemonic forces, each country has created its own cadre of rap groups and break-dance collectives that can be found on Africanhiphop.com. One can go online and read interviews with emcees or rappers such as Positive Black Soul, Pee Froiss, BMG 44, and Shiffai in Senegal; Unsung Heroes in Nigeria; Rev Voltod from Cape Verde; Karim \& Sphinx from Egypt; Prophets of Da City, Cavera, and Maluka in South Africa; Pox Presha of Nairobi; Sos-Bi of Tanzania; Kalamashaka in Kenya; Mabulu in Mozambique; Tata Pound in Mali; and many more. African female rappers are also represented, such as Alif in Senegal, Nubian Sister and Godessa in South Africa, and Afrik Image in Cote D'Ivoire. All of these African hip-hop emcees link their artistic lineage to Africa and the black Atlantic with specific African American 
rappers, internationally known African singers such as Yousou N'Dour and Miriam Makeba, and Caribbean pop stars. For example, Afrik Image of Cote D'Ivoire is composed of Queen Afrik, who names her inspirations as both Queen Latifah and Miriam Makeba, and Magic Law, who says she was inspired by Tanya St. Val's zouk music of the Caribbean. In their online interview, they present a new determined African female voice: "We have a rage inside of us. We want to succeed. If women can rap in the U.S.A., [we say] why don't [we] try it in Ivory Coast." ${ }^{10}$

Cultural and aesthetic resonances across Africa and the diapsora affirm a connective marginality of culture through hip-hop. In Africa and its diaspora, hip-hop is less of a sign to be appropriated and adapted for indigenous purposes (although this is definitely happening in other sites) than it is a sharing across a root aesthetic. Kenya and Senegal are consummate examples.

\section{SENEGALESE HIP-HOP}

Hip-hop seems to have arrived in Senegal around 1985 with some of the first Senegalese rappers: MC Lida, MC Solaar (who went on to make it popular in France), and Positive Black Soul (PBS). PBS was one of the first emcees to mix rap with mbalax, the traditional Senegalese drum music played in West Africa for centuries. A received African American cultural form was immediately adapted to fit local rhythms. This is quintessential diasporic aesthetic intertext in the reterritorialization process. Some of the newer Senegalese rap groups that have emerged in the 1990 s are BMG 44, Shiffai, Las MC, Slam Revolution, and Daara J. Although, on the surface, second-generation African rappers, such as Shiffai, seem to be following more of an American aesthetic with overt braggadocio, their method still falls into a traditional call-and-response aesthetic that is as old as the griot tradition.

In the post-Senghor era of Senegal of the late 1980s, Positive Black Soul became the rap group in Senegal who put African hip-hop on the international map. Consisting of Doug E. Tee (Amadou Barry) and Didier DJ Awadi from the Sicap Amitie district of Dakar, the emcee and deejay duo replicate the image of Eric B. and Rakim as the quintessential rapper-deejay hip-hop model of the early days of the hip-hop Bronx. PBS's first internationally successful album was the 1996 Salam on the Mango Island label, earning them subsequent tours on the African continent, in the United States, and in Europe as the early ambassadors of African hip-hop. Yet given this international recognition, PBS continued to steep its aesthetic in local languages and indigenous musical styles. 
More recently, they have established collaborations with Senegalese mbalax musicians Dieuf Dieul and Hamet Maal (the brother of famed Senegalese singer Baaba Maal) and with Doudou Ndiaye Rose, a living legend of Senegalese traditional drumming. PBS's artistic choices continue to centralize a Senegalese image that clearly has them representing an indigenous cultural aesthetic, "keeping it real" in the truest sense of hip-hop culture.

Setting the tone for successful African rap being sung in indigenous languages, PBS's first successful single, "Boul Fale," meaning "Don't Worry," was sung in Wolof. Africanist Moradewun Adejunmobi says in relation to the use of indigenous languages and, by extrapolation, lyrics in musical choices, "The actions we undertake and the discourses we produce in respect of various languages are determined in part by our relationships to the places where these languages are or might be spoken." ${ }^{11}$ Utilizing local indigenous languages is combined with the international language of commerce and popular culture: English. Hip-hop youth in urban Dakar reflect this phenomenon of mixing several languages in conversation that rap music often reflects: "In Senegal ... a conversational Wolof that incorporates both French and English expressions, functions as the 'trademark' of young men and has become directly associated in the perceptions of the Dakarois with the talk of the jeunes bandits de Dakar, 'the young low-lifes." 12 These "jeune bandits de Dakar" include the hip-hop youths who either come from the streets or, following hiphop's tendency of ghettocentricity, image themselves in that context. Therefore, language in African hip-hop becomes a way of positioning oneself in one's local particularity, as well as in the global cosmopolitan arena of popular culture from which the cultural forms have been received. This reterritorializing process establishes a continuum from local traditional language, including localized slang, to Black English and hip-hop slang, as it is imported from U.S. rap.

PBS's choice of Wolof and Dakar street slang as their preferred rap language is based not only on their locality but also on the hip-hop tenets of "keeping it real" and "representing." As Murray Foreman announced, "the 'hood comes first," 13 and this penchant for localized representation ("repping your hood") extends into the international sphere. Representing is the process of taking on the mantle from the past in the present moment, connoting responsibility to one's present context—crew, family, and community. Brenda Dixon Gottschild clarifies that 'the individual is obliged to 'represent,' in the hip-hop sense of the word, to rise and be counted for a specific community, to positively and righteously stand up for a 'crew.'" 14 If one is to represent one's cultural context, then 
the use of indigenous language and local cultural expressions are crucial in hiphop's globalized subculture.

I want to telescope out for a moment to investigate the larger contexts of transmission and reception of American music globally. One way to understand PBS's rap content, as well as various African hip-hop artists who privilege local culture, is by examining popular music theory. PBS and their audience "flip the script" of commercial U.S. rap, using the form to address their needs and concerns. Not only are youth in Senegal not totally abandoning their local cultures to be MTV cool; they are examining their local cultural values that they want to change. PBS not only included a local Wolof-slang language mix but underpinned the entire remix of "Boul Fale" with a reggae rhythm, steeped in a Jamaican dancehall rhythmic delivery of Wolof. Thus African American rap was reimaged with West African relevance through a well-established Jamaican musical form. The dialogue within the popular music of the black Atlantic became clear early on in African hip-hop with Positive Black Soul's aesthetic mix. Poet Kamau Brathwaite calls this black Atlantic musical resonance "bridges of sound." In so doing, Carolyn Cooper argues, Brathwaite

... evokes the substrate cultural ties that connect Africans on the continent to those who have survived the dismembering Middle Passage. The paradoxical construct "bridges of sound" conjoins the ephemerality of aural sensations with the technological solidity of the built environment. ${ }^{15}$

Indeed, Western technology has in many ways facilitated these "bridges of sound"; but so has the Africanist aesthetic heard back and forth across the Atlantic that is lodged in various social and cultural marginalities. The easy reggae groove of "Boul Fale" is deceptive, for the Wolof lyrics are a scathing social critique. In the lyrics, PBS accuses national authorities of corruption, one of the themes of many young hip-hop artists on the continent of Africa. But what makes the entire album Boul Fale significant is that it set the trend of sociopolitical critique for which African hip-hop is known, making this approach acceptable throughout the continent.

\section{KENYAN HIP-HOP}

Thousands of miles away, on Africa's east coast, Kalmashaka (aka K-Shaka) is a hip-hop group based in Dandor, a poor district in Nairobi, Kenya. This dynamic rap group, who paved the way for Swahili hip-hop to become more 
mainstream in Kenya, is comprised of three members: Oteraw, Kama, and Johny. Formed in the mid-199os, Kalmashaka became popular with their single "Tafsiri Hii" in 1998. Like Powerful Black Soul, they have performed in other African countries, such as Nigeria and South Africa, as well as having toured European countries, such as Sweden and Holland. Their first full-scale album, $\mathrm{Ni}$ Wakati, released in 2001, was a hit with South Africa's Channel O when one of their videos from the album got major rotation. African hip-hop groups that have managed to get exposure on an international scale have often become opening acts for American emcees and established African American rap artists, and Kalamashaka is no exception, having opened for Coolio and Lost Boyz.

Although K-Shaka has brought Kenyan rap to a larger audience, they remain known for their socially and politically conscious lyrics. Ni Wakati addressed street crime, tribalism, politics, and Africa's continuing revolutionary conflicts. Like PBS on Africa's west coast, K-Shaka's vision is to use rap music to awaken a new generation to contemporary political and cultural issues that intersect with past African discourses. However, each African hip-hop scene has its range of artistic content and form. Party and hardcore gangsta rap have always challenged the so-called conscious rap of the two groups on which I focus here.

In Africa, the added dimension of indigenous pop music intersecting with rap complicates the field. In Kenya, the popularity of so-called genege musicanother "bridge of sound" between hip-hop, dancehall, and Kenyan traditional music - promotes a more danceable beat, often laced with "raunchy" lyrics, which has become very popular among Kenya's youths. Genege, along with another genre called "kapuka," vies with the more conscious rap produced by groups like Kalamashaka for record sales and radio airtime. Kenyan radio is often reluctant to play socially conscious music typical of Kalamashaka because it challenges the status quo and often specific government officials.

During the political upheaval and violence in Kenya over the supposed rigged political process that elected Mwai Kibaki to the presidency in December 2007, hip-hop was a central sociopolitical commentator in the social discourse. With the serious challenge by Raila Odinga of the Orange Democratic Party and a member of the Luo ethnic group, violence against the Kikuyu, the largest Kenyan ethnic group to which Kibaki belongs, escalated. This longstanding ethnic rivalry erupted as a result of the presidential election, with over a thousand people being killed and three hundred thousand left homeless. A young rap group called the "Hip Hop Parliament" became hip-hop's spokespersons, denouncing the violence and voicing their generation's outrage 
about the destructive life-and-death hatreds perpetrated by their father's and grandfather's generations. In the process, Roje Otineo of the Hip Hop Parliament situated Kenyan youth in a definition of "conscious rap": "We don't play traditional drums like our fathers, nor do we depend on western culture. We don't care what your tribe is: our hip-hop is about love." Nickson Mberam of the same rap crew illuminated further, "I have a duty to my country and young people like me; I don't want to be part of the problem; we want to be part of the solution." The centrality of their message through hip-hop was borne out when Kofi Anan arrived in Kenya from the United Nations to try and broker peace. The Hip-Hop Parliament presented him with their own written declaration of peace. ${ }^{16}$ These contemporary African urban realities are now immortalized in indigenous raps, making this music crucial to the struggle over politics, culture, art, and the minds of today's youth.

The struggle between commercial and more "conscious" rap music is rarely brought to the level of dominant public discourse in the United States. Due to the all-pervasive multinational popular music, television, and general telecommunications industries that actually make music decisions for us, awareness of choice in rap music is usurped by the ubiquitous hold on the means of communication and distribution by companies like BMG, EMI, Universal, Viacom, and others. Because they only have access to commercial rap music, the majority of American consumers are not even aware of the struggle over hip-hop's representation.

In Kenya, Kalamashaka has remained active and refuses to record the more commercial Kenyan music. As a way of bolstering their ranks of conscious Kenyan rap music, K-Shaka has helped spawn other local rap groups from their Dandora district. They have also developed musical collaborations throughout Kenya and Tanzania, forming the rap collective Ukoo Fani Mau Mau, with over twenty members from Nairobi and Mombasa in Kenya and from neighboring Tanzania.

In their title track from $\mathrm{Ni}$ Wakati, they make explicit a world black movement for liberation that harkens back to the early twentieth-century PanAfrican movement of W. E. B. Du Bois, George Padmore, and Kwame Nkrumah. "Ni Wakati" makes a direct connection between the 1960s black liberation movement in the United States and Kenya's liberation movement from the British. On the track, Kalamashaka opens with an excerpt from a speech by Malcolm X, who acknowledged Kenya's Mau Mau revolutionary movement in the 1960s. In the track's opening, Malcolm preaches, 
There's been a black revolution going on in Africa. In Kenya the Mau Mau were revolutionary. They were the ones who made the word Uhuru. They were the ones who brought it to the fore. The Mau Mau were revolutionaries.

Just as Malcolm X used Kenyan's peasant Mau Mau revolutionary movement against the British colonialists to promote black awareness and empowerment in the United States, Kalamashaka uses Malcolm X's rhetoric to reinvoke the discourse of freedom in Kenya against neocolonialism today. Even as PanAfricanism as a global political movement has faded in the twenty-first century, the Pan-Africanist nature of black cultural efforts that promote black freedom and empowerment is becoming prominent through hip-hop's globalization in Africa. This points again to connective marginalities of historical oppression that resonates within hip-hop youth culture. Conscious African rappers are reinvoking a Pan-Africanist message that links decades of struggle for empowerment across the black Atlantic.

Malcolm X's use of the word uhuru (freedom) evoked many historical moments and can be associated with specific political and cultural movements. Besides the message of freedom of Kenya's Mau Mau movement, there was the 1960 s Uhuru Movement led by the U.S. African People's Socialist Party, which emphasized internationalism in the liberation of African people's worldwide. Other African and diasporic allusions are associated with uhuru as well. Jomo Kenyatta, a member of Kenya's Mau Mau movement and first President of independent Kenya (1964-78), named his son "Uhuru Muigal Kenyatta," and that son went on to become the leader of Kenya's African National Union, one of the main political parties of postcolonial Kenya. Additionally, one of Jamaica's most famous reggae groups, Black Uhuru, took the name as a way of identifying with black empowerment for liberation. Therefore, Kalamashaka's use of Malcom X's speech that emphasized the symbolism of uhuru reinvigorates a weakening worldwide black discourse of continuing struggle for freedom within the hip-hop generation in Africa.

With groups like Kalmashaka in Kenya and Positive Black Soul in Senegal, Africa's hip-hop movement is in tension with the current Top 40 rap music heard on American commercial radio. African hip-hop's focus, for the most part on social critique, black liberation, and specific political challenges on the African continent, is a far cry from the bling-bling booty music currently popular in the United States. African hip-hop, though itself consisting of a range of genres, tends to promote a consciousness-raising that is associated with the 
U.S. hip-hop underground scene, rarely heard by the majority of America's pop music audience. ${ }^{17}$

\section{CONCLUSIONS: CONNECTIVE MARGINALITIES OF CULTURE AND HISTORICAL OPPRESSION}

African rap music has much to teach hip-hop youth and the general public in the United States about the sociopolitical power and potential of hip-hop culture and rap music. Manthia Diawara, as an African scholar who teaches in the United States, also offers cross-cultural analyses of hip-hop through his generation of West Africans. He captures a cross-cultural and cross-generational connection in "Homeboy Cosmopolitan," a chapter in his 1998 In Search of Africa, where he explores his generation's identification with an earlier manifestation of black cultural production in collusion with America's pop culture industry: namely, the exported Blaxploitation films of the 1970s. Being a Malian living in Monrovia, Liberia, in his early years, Diawara was struck by how much that West African country identified with the United States (which is not that surprising given its history with U.S. slavery and the debacle of the repatriation movement). He says,

I saw Superfly, Shaft, and other Blaxploitaiton films in Monrovia in the early Seventies. I remember being particularly struck by the opening sequence in Superfly — it seemed an extraordinary cinematic event. I was . . f fascinated with the movies, the music, the hairstyles, the hats, and the leather jackets what were popular among black Americans ... To my students [at NYU now], these films are at best corny, and at worst celebrations of black men's macho, violence, and misogyny. They also find exotic the fact that although I was living so far away and in a completely different culture, I could identify with Blaxploitation films.

But my students tend to overlook the elements of empowerment and pleasure and the subversive strategies that these films, and black American culture in general, make available to people oppressed because of the color of their skin. ${ }^{18}$

One of our foremost African film scholars and cultural critics has captured two important points about the transatlantic music and cultural exchange between African Americans and Africans: (1) historically, several African generations, including the current hip-hop one, have been fascinated with black American style and cultural production as the world black population setting 
global trends from the richest country in the world; and (2) this style is a part of an Africanist aesthetic that has provided, in Diawara's words, "elements of empowerment and pleasure" for black Americans themselves, as well as for blacks throughout the world, including Africa. The process of claiming one's power of identity in the face of oppression-whether it be racial as in the United States, or ethnic, class, or political, as in the case of many African countries-becomes an important process promoted by this aesthetic that has its latest manifestation in exported hip-hop culture.

Realistically, African American blues, swing, jazz, funk, and hip-hop have evidenced little conscious referencing of Africa, however much they may have shared aesthetic principles. Yet a continuing twentieth-century secularization of an aesthetic that originally made little distinction between sacred and profane realms is the historical legacy now bequeathed to the African homeland from its diaspora. Sub-Saharan black Africa, then, owes a great debt to its diaspora for the many manifestations of metaphoric embodiment and cultural recreations of its own ontology-like the centrality of music and dance for constituting community, as well as aesthetic principles such as polyrhythm, a danced orality, a call-and-response dialogue approach, and use of performance to represent social phenomena.

To be sure, Africa has recognized these New World resonances in the past, as evidenced by the midcentury rhumba orchestras of Kinshasa, the jazz bands of Accra, and the popular dance styles in Ghana's urban discos after the early 1970 S Soul-to-Soul tour with groups like Ike and Tina Turner and the Voices of East Harlem. The contemporary hip-hop movement has intensified this repatriation of black American music and dance, linking distant African sites such as Lagos, Dakar, Cape Town, Dar es Salaam, and Nairobi, among others. Connective marginalities of culture, class, historical oppression, and youth in opposition to adult sociopolitical authority facilitate these historical and contemporary resonances made manifest through rap music and hip-hop culture.

The Akan symbol known as sankofa is a bird with its head turned back toward its past. I view hip-hop in Africa in terms of this cosmological tenet of temporal circularity. The black Atlantic looks back to its African traditions and sends musical and danced messages filtered through its black Atlantic voices that are in turn heard and reinvented in Africa. In the cases of Senegal's Positive Black Soul and Kenya's Kalmashaka, we witness this theory in practice by their reterritorialization of an African American music form, recasting it in their own lived experiences and meanings. African American emcees and the entire U.S. rap audience have much to learn from African rap groups like Positive 
Black Soul and Kalamashaka. The reinvoking of a world black revolutionary movement, not yet finished, is an important contribution from African hiphop that could ameliorate current U.S. hip-hop's obsessive diversion in American capitalist materialism.

\section{Notes}

1. See Osumare, The Africanist Aesthetic in Global Hip-Hop: Power Moves (New York: Palgrave MacMillan, 2007), for a full explanation of connective marginalities. This is my theory of one of the primary reasons for hip-hop's international proliferation, particularly found in Chapter 2.

2. I define the "Africanist aesthetic" as African-based cultural forms and philosophical approaches existing in the African diaspora that continue to reflect similar musical, dance, and oral practices as those in Africa; though these forms and approaches are not African, enough resemblances in the performers' attitude and relationship to audience exist that cultural connections to African cultural practices are apparent.

3. Bennett, Popular Music and Youth Culture, 35.

4. Ibid., 55 .

5. Ibid.

6. See "African Hip Hop Music."

7. See "Africa-Wake Up \& Unify" (accessed July 1998).

8. Drew and J4, "Debate."

9. Diawara, "Toward a Regional Imaginary," 103.

10. Afrik Image, interview at Rumba Kali.

11. Adejunmobi, "Polygolots, Vernaculars, and Global Markets," 159.

12. Ibid., 166. Here, Adejunmobi quotes Swigart, "Cultural Creolisation," 7.

13. Forman, 'Hood Comes First.

14. Gottschild, Black Dancing Body, 231.

15. Cooper, Sound Clash, 231.

16. "Kenyan Hip-Hop Artists Use Music to Denounce Violence," Rock theVote.com, March 10, 2008, http://www.hiphoplinguistics.com/news/2008/03/kenyan-hip-hopartists-use-music-to-denounce-violence.

17. The so-called hip-hop underground is an important aspect of the subculture with which hip-hop entrepreneurs must continually engage. Street agency and the hiphop underground form a web of affiliations, associations, and cliques that supposedly "keep it real" without compromise of artistic integrity or "selling out" to pop culture gatekeepers. This branch of hip-hop argues that commercial hip-hop entrepreneurs cannot engage in effective counterhegemonic activity while courting capitalist materialism. The underground forms a perceived significant resistance to the commercial hiphop and rap industries. The lifestyle of the rich and famous that is lived by the black millionaire moguls of rap music is considered not "keeping it real" by many hip-hop communities across urban America who promote their own indie record labels, blackmarket street mixes (on tapes, CDs, and DVDs), b-boy collectives, and rivaling graffiti contingents. However, this dichotomy between underground and commercial is often a 
false one, adding an even more complex layer to the analysis of hip-hop outside the United States.

18. Diawara, In Search of Africa, 247, 250, 252.

\section{Bibliography}

Adejunmobi, Moradwun. "Polyglots, Vernaculars and Global Markets: Variable Trends in West Africa." Language and Intercultural Communication 4, no. 3 (2004): 159-74.

"African Hip Hop Music.” Wikipedia. http://en.wikipedia.org/wiki/African_hip_hop.

"Africa-Wake Up \& Unify." Rumba Kali: The Home of African Hip Hop home page. July 1998. http://www.africaserver.nl/rumba-kali. Accessed December 15, 1998.

Afrik Image. Interview at Rumba Kali: The Home of African Hip Hop, May 1996. http://www. africaserver.nl/rumba-kali/index2.htm. Accessed December 15, 1998.

Bennett, Andy. Popular Music and Youth Culture. New York: St. Martin's Press, 2000.

Cooper, Carolyn. Sound Clash: Jamaican Dancehall Culture at Large. New York: Palgrave Macmillan, 2004.

Diawara, Manthia. In Search of Africa. Cambridge: Harvard University Press, 1998.

Diawara, Manthia. "Toward a Regional Imaginary in Africa." In The Cultures of Globalization, edited by Frederic Jameson and Masao Miyoshi, 103-24. Durham, NC: Duke University Press, 1998.

Drew and J4, hosts. "Debate: The Satanic Versus The African Dilemma." Webcast, December 1, 2006. http://www.africanhiphopradio.com/. Accessed January 12, 2007.

Forman, Murray. The 'Hood Comes First: Race, Space, and Place in Rap and Hip-Hop. Middletown, CT: Wesleyan University Press, 2002.

Gottschild, Brenda Dixon. The Black Dancing Body: A Geography from Coon to Cool. New York: Palgrave Macmillan, 2003.

Osumare, Halifu. The Africanist Aesthetic in Global Hip-Hop: Power Moves. New York: Palgrave Macmillan, 2007.

Swigart, Leigh. "Cultural Creolisation and Languages Use in Post-Colonial Africa: The Case of Senegal." Africa: Journal of the International African Institute 64, no. 2 (1994): $175-89$. 


\section{New York Bomba: Puerto Ricans, Dominicans, and a Bridge Called Haiti}

\section{RAQUEL Z. RIVERA}

It must have been around 1995, and I had just witnessed an energetic performance by the Brooklyn-based Haitian roots music ensemble Dja-Rara at a show produced by the Caribbean Cultural Center in a large Manhattan theater space. Dja-Rara's main dancer had particularly captivated me: a short, stocky, young, light-skinned man with a rotund and bouncy belly. His moves were equal parts aqueous and fiery, stern and graceful—a beauty to behold.

I was still electrified by the musicians and dancers who had left the stage only minutes before and was only half listening to the mistress of ceremony, who was waxing eloquent about the cultural similarities between Latinos and other African descendants. The next group scheduled to perform was from the Spanish-speaking Caribbean, and her words were geared toward making the linkages between them and Dja-Rara.

A male voice behind me protested loudly, "Latino? Oh, hell, no!"1

Murmurs of approval floated toward me from the same direction. I was tempted to look back but resisted the impulse.

When the mistress of ceremony said the word Latino again, the same voice exclaimed, "We gotta stop with that 'Latino' thing. It just separates us from each other. If we're black, we're black. That's it."

I finally looked in his direction. He was only two rows behind me. It was the dancer from Dja-Rara, surrounded by a few other members of the group. My eyes met his bright yellow gaze, his impish smile.

Later that night, a mutual friend introduced us in the theater lobby. His 
name was José Figueroa. A Dominican in his midtwenties, he was born in New York City, raised between the Dominican Republic and New York.

I did not know then that, over the next decade, his path would cross mine many, many times. Back then I considered myself a music enthusiast, not a performer, so there was no way I could have suspected that we would become fellow members of the Afro-Dominican musical group Pa' lo Monte or that he would become my teacher, an important member of my immediate artistic community, and a key individual in the musical work that would be the axis of my intellectual, artistic, and social life in New York City for the next ten years.

Back when I met Figueroa, I was conducting my dissertation research on the role of New York Puerto Ricans in hip-hop culture. His bold interjections from the audience at the Caribbean Cultural Center's show struck me for many reasons, in part because they echoed the sentiments of a Puerto Rican MC by the name of Q-Unique that I had recently interviewed who also resented the label Latino. But Q-Unique's qualm with Latino had to do with Puerto Rican ethnic identity being subsumed under the Latino panethnic umbrella so that Puerto Rican specificities were glossed over. Q-Unique also disliked the erroneous and much-too-common assumption that Puerto Rican connections to African Americans were more tenuous than their connection to other Latino groups. It was not that Q-Unique identified as African American or black; on the contrary, he resented just as much being lumped under the African American or black umbrella. It was just that Q-Unique felt culturally and experientially closer to African Americans than to Chicanos-to bring in the concrete example he used at the time. ${ }^{2}$

While José Figueroa, like Q-Unique, also had qualms with the label Latino, the former's main objection was completely different: rather than the erasure of his national/ethnic identity, Figueroa took exception to having his ethnoracial identity as an African descendant and a black man from the Dominican Republic subsumed under the panethnic rubric. Figueroa is not alone either in his objections or in his commitment to combating - as an artist and cultural activist - the prevalent discourses of Latinidad (Latinoness), which claim to include blackness as a constitutive element yet also insist that the result is other than black. ${ }^{3} \mathrm{He}$ is part of a vocal and active transnational network of artists, scholars, educators, and activists who have, in the last decade, been stepping up a long legacy of efforts that promote a vision of the African diaspora that fully includes the Luso-Hispanic black Atlantic. One individual in that wider transnational network, Figueroa has also, for years, been an important fixture within 
a microcosm of folks who make and promote Caribbean roots music in New York. It is their efforts that I chronicle here.

This essay is a fragment of an ethnography (and a love letter of sorts) of an extended circle of New York musicians and dancers, most of them Puerto Ricans and Dominicans who also double as educators, cultural workers, and activists. Though an intergenerational group, I focus on those in their teens, twenties, and thirties. Through this discussion, I seek to document the artistic creativity, beauty, ideas, potential, and contradictions of a musical/social scene-a microcosm that I am also a part of.

My focus in this essay is these artists' foregrounding of Afrodiasporic expressions, traditions, myths, knowledge, identities, and solidarities for aesthetic, political, philosophical, social, cultural, educational, and spiritual reasons-a foregrounding that questions the hegemonic notions of Latin American/Latino nationality/ethnicity/panethnicity that, under the guise of inclusiveness, perpetuate the marginalization of blackness. ${ }^{4}$ Through their praxis, these artists counter the dominant approaches, efforts, pronouncements, and projects that claim to be celebrating "our black traditions" (nuestras tradiciones negras $)^{5}$ but that arguably succeed in colonizing, folklorizing, taming, and bringing these traditions back around to the business-as-usual white supremacist, Eurocentric, or "racial mixing as panacea" fold. ${ }^{6}$

Though ranging widely in terms of phenotype, the majority of the artists I write about here are black-identified-and all of them are fiercely invested in centering blackness and combating racist hierarchies. Their explicit black identification is an important tool in the artistic work that I document. ${ }^{7}$ However, this essay will not be devoted to grappling with the "contested politics of naming." 8

Robert Farris Thompson has often invoked the poignant image of New York as the crossroads of Afrodiasporic cultures. Hip-hop, salsa, dancehall, boogaloo, Latin soul, Latin funk, Cubop, and Latin jazz are but a few of his musical examples. The musical practices I discuss in this essay are contemporary testimony to the fact that New York is still a crossroads of the African diaspora. This image of the New York crossroads where the Puerto Rican and Dominican musicians featured here meet is just as important to this essay as the concept of Haiti as the mythical bridge that connects Dominicans and Puerto Ricans to each other, to the rest of the African diaspora, to ancestral knowledge, and to themselves. In a way, New York is the physical crossroads, while Haiti is the mythical/spiritual bridge-kind of like Guinee/Ginen ${ }^{9}$ has served for Haitians, as one of the artists I focus on in this article sharply observes. 


\title{
NATIONALIZING AND TRANSNATIONALIZING BOMBA
}

Bomba is an umbrella term that describes the oldest known Afro-Puerto Rican music. Probably developed during the seventeenth century, it encompasses numerous subgenres-known as seises, sones, golpes-like yubá, calindá, sicá, cunyá, bambulaé, and numerous others. Many of these same (or similar) terms or rhythmic patterns are/were found in Cuba, Haiti, Trinidad, the Virgin Islands, and the southern United States, among other locales. Bomba lyrics often incorporate words derived from Kongo-Bantu languages and Haitian Kreyòl, among many other linguistic sources. ${ }^{10}$

Among the best-known examples of Kreyòl-derived bomba lyrics is the following song that mixes Spanish and the Puerto Ricanized version of Haitian Kreyòl. By no means an obscure example, it is part of what has become the "bomba canon" as practiced in the late twentieth and early twenty-first centuries in Puerto Rico and the diaspora.

\section{Miserere congo misié}

¿Dónde está mi congo laré?

In an unpublished manuscript, Carlos "Tato" Torres translates the lyrics into Kreyòl as

\author{
Misey Kongo Misey \\ ¿Kotê ma Kongo Larèn?
}

He translates the same lines into English as

\section{My Sir Kongo My Sir \\ Where is my Kongo Queen? ${ }^{11}$}

As Torres notes in his analysis of this song, the Haitian influence is both linguistic and spiritual. While the song makes mention of the family of spirits in Vodou known as Larèn Kongo, other bombas pay homage to the lwa, or spirit, Damballah, as evidenced by the title of "Damba Yaribe"12 (in English, "Damballah/the Holy Serpent Has Arrived"), a song recorded in early twentieth-century Puerto Rico by the anthropologist J. Alden Mason. Damballah is also referenced in the following song collected by María Cadilla and cited by Luis Alvarez Nazario. 


\section{Dambambá, tinguiní;}

que la culebra comió el ají;

Dambambá, tinguiní,

ño Sico baila, culebra, ají. ${ }^{13}$

Widely acknowledged to be the most heavily African of Puerto Rican musical traditions, bomba is popularly explained as an exemplary product of the mythical racial trilogy that purportedly underlies the Puerto Rican cultural expressions branded "national." 14 Bomba is often described as a result of the combination of three "cultures": Taíno, Spanish, and African. ${ }^{15}$ Each of these cultures is frequently explained as visible in bomba through clichéd (and often misleading) characteristics. Thus, for example, the use of maracas, or gourd rattles, is identified as being of Taíno origin, but these were musical instruments also present in the African continent prior to the European colonization of the Americas; lyrics that are unintelligible to a general public today are assumed either to have always been gibberish ${ }^{16}$ or to have been derived from African languages, but they have often been imported from the creolized languages of neighboring Caribbean islands; and the "traditional" style of dancing and dress of performing groups is explained as deriving from Spanish sources, eliding how these "traditions" have been partly invented and partly reconstructed by privileging and branding as "national" the traditions of certain social sectors at certain points in time. ${ }^{17}$

The 2001 Banco Popular-sponsored music special Raices, though offering a more complex than usual portrait of bomba through the incorporation of multiple voices, narratives, and perspectives, still reiterates the much-touted trilogy. ${ }^{18}$ The myth of the racial trilogy purports to emphasize and promote Puerto Rican ethnoracial diversity and inclusiveness, but it has actually been a central tenet of Hispanophilia and Afrophobia, Latin American-style.

In an article dedicated to examining the "folklorization" of blackness in Puerto Rico, Isar P. Godreau argues that-the celebration of the racial trilogy notwithstanding - it is Hispanic heritage that is seen as the "essence" of the nation and that blackness, when and if celebrated, is construed as an exception. She writes,

Racial purity is, in that sense, only recognized in the past, while mixture is understood as the mark of the present. Yet, while race is mixed and de-essentialized at this point, the cultural outcome of that hybridity is construed as a homogenous national product. As a result, when the phenotypic and cultural 
signs of blackness are celebrated in their own terms they are often rendered as remnants of a past era that has been replaced by a modern, mixed present. ${ }^{19}$

The nation and national culture, coded as racially "mixed," are usually celebrated without an acknowledgment of the power relations that have informed them and continue to inform them. Bomba and plena-the genres Halbert Barton has described as the "color-coded folkloric dyad" that functions as a euphemism for "black people's music"20 — are thus paid tribute to, most notably by the state, while concealing "how such creations were forged in the context of discriminatory practices that still persist." ${ }^{21}$

Bomba has been praised as "black people's ballet" and "black people's minuet" in Puerto Rico, most notably by singer Ruth Fernández. ${ }^{22}$ She quoted her own aphorism for the cameras in the Raices 2001 music special. Already in her late eighties when the filming took place, she starred in some of its most poignant moments. One of them is when she recounts a painful (but victorious) incident when, as a black artist in mid-twentieth-century Puerto Rico, she was expected to enter through a hotel's back door but refused and entered (to everyone's shock) through the main door. Another one of those most powerful moments in Raíces is when—seated in a regal-looking wicker chair and decked out in a puffy-sleeved, full-length pink gown, chunky gold necklace, and scores of rings and jingling bracelets—Fernández proudly describes bomba through the ballet and minuet comparison. Salvador E. Ferreras notes, regarding Fernández's metaphors,

Good intentions notwithstanding, this type of characterization is no longer shared by younger participants who would rather raise the profile of bomba on its own merits rather than by linking it to an archaic dance of the European colonial elite. ${ }^{23}$

Ferreras, paying close attention to bomba as it is being practiced by the younger generations on the island as well as in the diaspora, also remarks, "Nationalism, identity politics and an underlying racial ambiguity [emphasis mine] surface as important factors in bomba's renewal." ${ }^{24}$ A decade earlier, Halbert Barton had also pointed out the primacy of the national framework, using Modesto Cepeda's ${ }^{25}$ bomba school (located in Santurce, Puerto Rico) as an example. This national framework is not unraced; rather, it is understood as fundamentally racially mixed. After pondering the implications of the remarks of Ketty Cepeda (Modesto Cepeda's wife) to her students regarding the unique- 
ness and value of their extremely varied phenotypes when compared to the groups representing other countries that they encountered in international folk dance competitions, Barton concluded,

Their Puerto Rican group had all the colors in the rainbow, and this was something to be proud of and valued for its own sake. In the school context, then, bomba dancing became a source of reflection about Puerto Ricanness rather than blackness itself. ${ }^{26}$

On October 11, 2004, an El Nuevo Día newspaper article titled "Bomba Incites a Heated Debate" had Modesto Cepeda vehemently objecting to historian Lester Nurse Allende's account of bomba's origins. ${ }^{27}$ According to the article, Nurse Allende stated that his research led him to conclude that bomba is not "essentially Puerto Rican." His examples included the fact that bomba's "seises had names in Creole rather than Spanish," as well as the close similarities of its various instruments (in terms of confection and nomenclature) with instruments found in Haiti, Cuba, Martinique, Guadeloupe, and Nicaragua. Cepeda, visibly upset, confronted Nurse Allende: "You cannot tell me that bomba is not Puerto Rican. I completely reject that. This is disrespectful.” The article also reports that Cepeda stated he did not want to be African but was Puerto Rican and proud of it and that Cepeda questioned the accuracy of Nurse Allende's pronouncements by brandishing his bomba lineage and Nurse Allende's lack thereof.

While stressing bomba's national identity is obviously Cepeda's priority, Nurse Allende's is not. Decentering bomba's Puerto Ricanness strikes Cepeda as disrespectful, whereas for Nurse Allende, it seems to be an opportunity to foreground bomba's Afrodiasporic linkages. While Cepeda places emphasis on a national framework, Nurse Allende privileges a Caribbean one.

Nurse Allende's efforts to locate bomba within a transnational Afrodiasporic framework can be interpreted in great part as a strategy to elide the constraints of the "national" straightjacket placed on bomba. In theory, nationalizing bomba does not have to perpetuate the marginalization of blackness. Yet it does. Isar P. Godreau notes how "celebratory renderings of blackness," such as bomba's enshrinement as a "national" music, routinely end up perpetuating the existing structures of dominance and oppression.

This inclusion and celebration of blackness is not distinct from but instead complements ideologies of blanqueamiento because it is rooted in some of the same ideological principles that distance blackness, geographically and tempo- 
rally, from the imagined margins of the nation. This distancing has the effect of locating the phenotypic and cultural signs of blackness "somewhere else."28

Lester Nurse Allende's transnational, Caribbeanist, and Afrodiasporic perspective seeking to destabilize the status quo of bomba as folklore ${ }^{29}$ and bomba as national is the one that the circle of musicians I document here find extremely inspiring and insightful.

\section{SICAMÁ MOYÓ AND URBAN MAROONAGE}

Alma Moyó was founded in 2002 by New York-raised Puerto Rican Alexander Lasalle, then twenty-three years old. ${ }^{30}$ It is a New York-based musical group whose name translates as "Soul Soul" - Alma being in Spanish, while Moyó is the creolized version of a Kikongo word widely used in the Afro-Cuban Palo Mayombe religious tradition Lasalle is initiated in. ${ }^{31}$

Presently, most of Alma Moyó's members are in their twenties. I was twenty-nine years old when the group was founded and have since been one of its "elder" members. Though the group attracts audiences of all ages, our core following consists of people under forty. We play most often at music festivals, bars, nightclubs, spiritual ceremonies, activist fund-raisers, and colleges and schools in the tristate area. Eight of Alma Moyó's eleven members are Puerto Rican, and three of its key drummers are Dominican. The group is dedicated to playing bomba.

"To hell with ballroom bomba! This is maroon bomba!" irreverently exclaimed Alma Moyó's founder and director during a 2005 performance in the East Harlem bar Jake's. ${ }^{32}$ Lasalle's statement was, in part, a reaction to the colonial/European "costume" and dance movements promoted through the dominant "folklorized" expressions of bomba. ${ }^{33} \mathrm{He}$-along with other practitioners of the younger generations - characterizes the costumes women often wear as frozen-in-time, caricaturesque "mammy outfits." ${ }^{4}$ Regarding wearing the outfits, Lasalle later told me in conversation, "It's like performing in blackface!" The "maroon" aesthetic self-consciously promoted by Alma Moyó includes emphasizing the participatory, jamlike quality of bomba musical events (rather than its "performance" aspects) $)^{35}$ and vindicating the much-vilified community tradition of street bomba in the town of Loíza, which has been described as "vulgar" (too much hip movement, backs not straight enough, movements not "elegant" enough) and "impure" (due to incorporation of Afro-Cuban instruments, songs, and rhythms). 


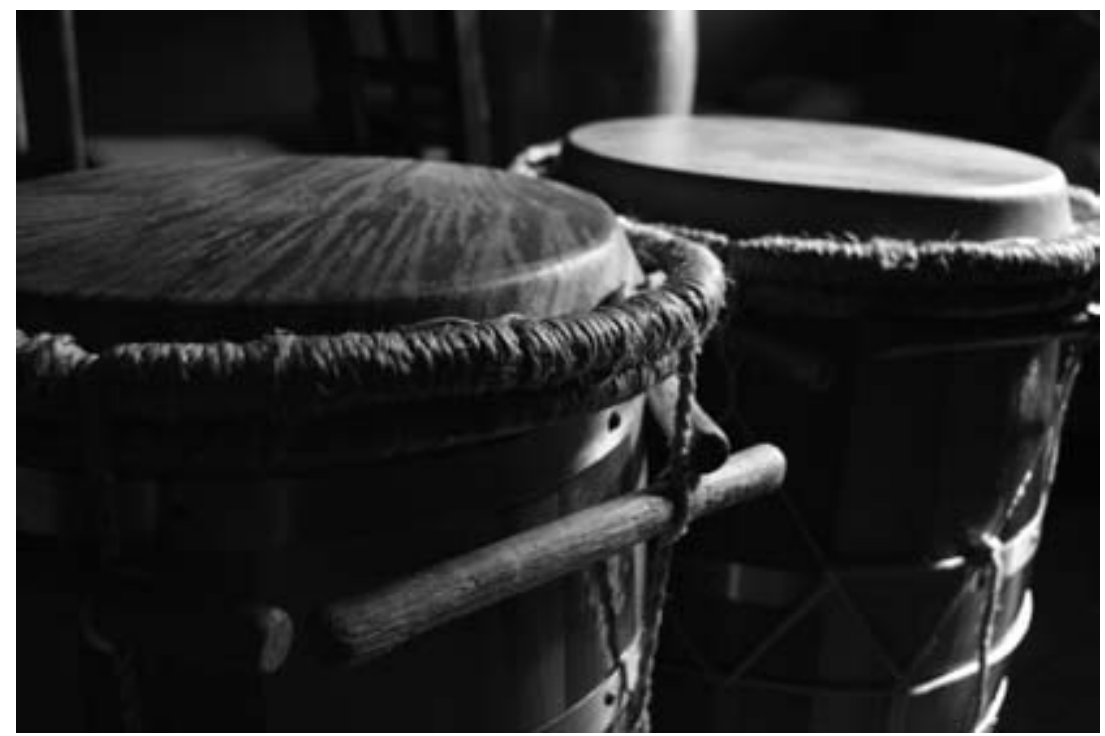

Alma Moyó's bomba drums, built by Puerto Rico-based master drum makers Papo del Valle and Iván Dávila. (Photo by Elias Irizarry Rosado.)

Lasalle's defiant remarks struck a chord with the crowd that night at Jake's, particularly for those who had been present during an infamous incident a few months earlier in late 2004 when Margarita "Tata" Cepeda, a Puerto Rico-based high-profile dancer and niece of Modesto Cepeda, stopped a Bronx bombazo (where she was a guest) because she felt affronted by the disrespect bomba was allegedly being treated with, particularly by the younger participants. Her complaints? The sensual brashness of some dancers' movements, the throwing of elegance out the window, the mixing of bomba steps with hip-hop and rumba. Her irate actions that night were undoubtedly informed by the reigning bomba dance aesthetic promoted by the most influential exponents of bomba in the last fifty years: her own Cepeda family, whose key words for dancing bomba are "elegance," "posture," and "firmness" (elegancia, postura, firmeza)—straight backs are privileged, and too much pelvic movement is shunned. "Elegance," being in the eye of the beholder, is a highly contested aesthetic concept. Ironically, the Cepedas-hailing from the northeastern town of Santurce - and their disciples have been criticized by elders from the southern region of the island ${ }^{36}$ for not being "elegant" or "graceful" enough. ${ }^{37}$ 
Of course, arguments about dance aesthetics are never objective or just about aesthetics. Underpinning Tata Cepeda's feeling of entitlement to stop the music at the Bronx bomba jam and reprimand the participants-particularly the teenagers and twenty-somethings—-was not only her national/international renown as a bomba dancer and her membership in bomba's best-known family but also underlying assumptions about New York bomba not being as "authentic" as bomba on the island. ${ }^{38}$ Part of its alleged lack of authenticity is precisely that it is being "fused" with other dance forms like hip-hop and rumba. Her comments generated months and months worth of conversations, writings, and public puyas (veiled criticism).

Tata Cepeda is actually well known for her signature and innovative bomba steps developed through the incorporation of flamenco-inspired moves. The irony was not lost for observers present during the Bronx public admonishment. Some of the younger ones later observed that at least the dance forms being fused in New York are all Afrodiasporic (bomba, hip-hop, rumba) and part of the same "family," while bomba dancers in Puerto Rico are incorporating dance moves from further removed sources like flamenco and ballet. These observers were undoubtedly placing a premium on fusing bomba with other Afrodiasporic practices. Awilda Sterling Duprey, a highly regarded performer in modern dance as well as bomba, seems to agree.

To my understanding, the act of dancing, in the case of the popular genres, is an intuitive response of rhythmic/musculoskeletal associations blended by the idiosyncratic sensory framework that the dancer possesses. Accordingly, it is perfectly acceptable (that is, if one's mind is receptive to the reasoning behind contextual change) that in New York so many stylistic variants are added to the traditional patterns danced in Puerto Rican bomba, given the variety of homonymous cultures with the sociopolitical and economic distortions and processes that are in constant interchange in the city. ${ }^{39}$

As a witness to the underpinnings and aftermath of Tata Cepeda's public reprimand at the Bronx bombazo, I was struck by the level of heat, anger, pain, and controversy that can be generated by debates regarding aesthetic standards. Ironically, rather than serving to tame the "disrespectful" New York bomberos, it made many of them even more defiant and committed to locally based community standards where mixing bomba, rumba, hip-hop, and Dominican roots musical traditions may be framed not as "inventing" or "experimenting" but as employing practitioners' "maternal" expressive languages. ${ }^{40}$ Given the intense 
participation and interaction in the bomba scene between New York-raised Puerto Ricans and Dominicans (more on this topic in the next section)_folks often having grown up more exposed to hip-hop and rumba than to bomba, palos, or other roots musical traditions of Puerto Rico and the Dominican Republic — the quest for "roots" takes on very particular characteristics.

\section{BARÓN/BAWON AND A BRIDGE CALLED HAITI}

Another important element of Alma Moyó's self-described maroon aesthetics is the acknowledgment of the Afro-Caribbean spiritual dimension of bomba, an aspect that has been consistently denied in both popular and academic forums - though it has been gaining credence in the last few years.

During another full-house performance at Jake's during 2005, Alma Moyó played well-known traditional bombas as well as a number of original bombas and traditional Dominican palos songs dedicated to San Elías (Saint Elijah), a spirit also known as Barón del Cementerio (Baron of the Cemetery) in Puerto Rico and the Dominican Republic and as Bawon Simityè in Haiti. Lasalle regaled the spirit - much beloved within certain branches of Puerto Rican espiritismo (Spiritism), as well as in Dominican santería/vudú/espiritismo and Haitian Vodou-with two new songs. One of them we performed as a 6/8 leró rhythmic pattern:

Leró leró San Isidro

Leró leró sanse mué

Leró leró San Elías

Padre de los muertos, San Elías priyé

Lero lero Saint Isidore

Lero lero my saint

Lero lero Saint Elijah

Father of the Dead, pray for us

The lyrics pay homage to both San Elías and San Isidro Labrador. The reason for the double homage, Lasalle explains, is that both spiritual entities often "work together" in espiritista traditions. Furthermore, following the example of other bomba songs passed down through the generations, Lasalle has integrated Kreyòl into his compositions, choosing the same Kreyòl words that of- 
ten appear in much older, traditional bombas that mix Spanish and Kreyòl: mué (mwen; in English, "me " or "my”) and priyé (priye; in English, "pray”). The term leró itself is a term derived from Kreyòl, though there are different takes on the original term: while some have said it derives from "le rose" (the rose), others say from "le rond" (the circle). ${ }^{41}$

Lasalle and Ernesto Rodríguez, then an Alma Moyó member, ${ }^{42}$ traded verses in the U.S. spiritual "Lay This Body Down" (Oh graveyard, oh graveyard / I'm walking to the graveyard to lay this body down) to a cunyá bomba pattern. Lasalle also sang another of his originals, this time to the rhythms of a bomba holandé, and Ernesto Rodríguez later sang a song from the Dominican salves/palos tradition-both songs dedicated to San Elías, their lyrics closely mirroring each other. Though I wrote down many of the night's details the day after this performance, I failed to note if the percussionists played a bomba holandé for Rodríguez's song or if they played palos or salves. Though I wish I could remember the choice made that night, I find my own lack of clarity and precision somewhat befitting to the degree of fusion between the two national traditions as Alma Moyó and others practice them. Oftentimes we have sung Dominican tunes to a bomba rhythmic pattern and on bomba drums, and almost just as often we have sung them to salves or palos rhythmic patterns played on bomba drums.

That night, Lasalle wore a huge top hat, a black suit jacket with a purple handkerchief tucked in the breast pocket, and sunglasses, in tribute to El Barón/Bawon and the way that he is traditionally rendered. Though not explicitly stated during the performance, Alma Moyó paid homage that night to the powerful spirit that rules over cemeteries and thus over the dead-and we did it by stressing the commonalties among diverse African-derived musical and spiritual traditions in the Americas. But these were not haphazardly chosen commonalties: just like the Barón del Cementerio was the numinous entity providing the spiritual glue for our performance that night, Haiti was the historical and mythical bridge linking the traditions of Puerto Rico, the Dominican Republic, and even the southern United States.

Manuela Arciniegas, another of Alma Moyó's Dominican members and one of the very few female percussionists who plays the lead drum among existing bomba groups, was raised "speaking Puerto Rican Spanish" in the South Bronx. The twenty-eight year old began playing Dominican and Puerto Rican roots music as soon as she returned to New York once she completed her undergraduate degree at Harvard. She says: 


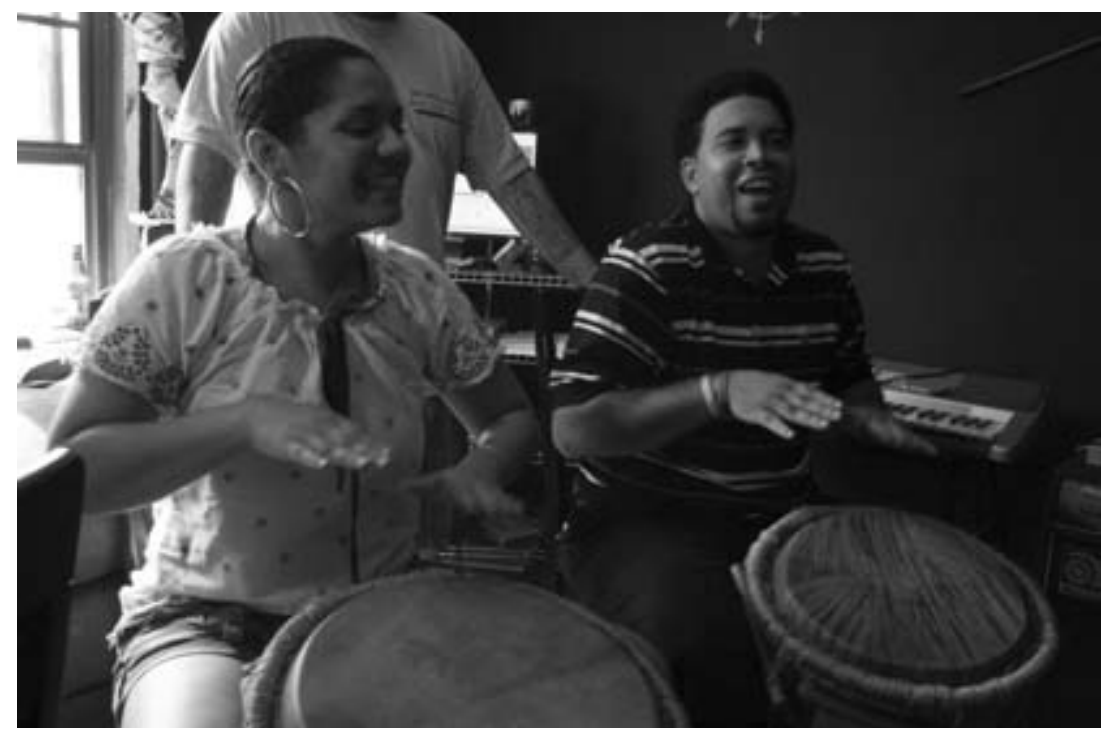

Alma Moyó's Manuela Arciniegas and Obanilú Iré Allende Solana at the 2008 recording of the Freedom album spearheaded by the Welfare Poets as a fund-raiser for Puerto Rican political prisoners. (Photo by Elias Irizarry Rosado.)

My spirit called me to bomba, early. I had access to palos and I loved it, but then something happened with bomba where it was a new beginning. I always felt like it was mine and it's strange cause I'm Dominican. But it's like my spirit is like, "No, this is a big part of who you are." So when I started hearing about the Haitian roots [of bomba] I got really excited. I'm like, "Oh, the point of connection was like three generations ago with my Haitian ancestors and your Haitian ancestors and they're on both islands!" Let's celebrate that. It's important to get rooted in those spaces where the cultures overlap, the times overlap, descendancies overlap. ${ }^{43}$

Rather than just celebrating bomba as a national Puerto Rican musical tradition or a Latin American music phenomenon, Alma Moyó places a greater priority on practicing/performing bomba within the context of Afrodiasporic traditions and exploring most profoundly the connections between roots music in Puerto Rico and the rest of the African diaspora-particularly the Dominican Republic and Haiti. The group's self-description provides a good example. 
Alma Moyo's signature contribution to La Bomba includes promoting spiritual and revolutionary Bomba songs and practices obtained through years of research throughout the island of Borinquen. Our music celebrates the connection between all descendants of the African Diaspora in the United States, the Caribbean, and Latin America. Our goal is to create a cultural revolution that promotes our Afro-Caribbean identity through an exhilarating rhythmic journey. ${ }^{44}$

In that challenging of the dominant discourses that perpetuate the blackness/Latinidad divide or that promote the national framework as the most important one, Alma Moyó is certainly not a lone exception but an example of a larger cultural phenomenon in New York City. They are merely part of a small but vocal circuit of Caribbean roots musicians-many of them Puerto Rican and Dominican - who know and collaborate with each other. Between four to six members of Alma Moyó have at one point or another been part of the Dominican roots music groups La 21 División, Pa' lo Monte, Palo Mayor, Claudio Fortunato y Sus Guedeses, and Kalunga Neg Mawon. Other examples of New York-based musical groups that include (or have included) both Dominican and Puerto Rican members (and that, to varying degrees, highlight the connections between the musical traditions from both countries) are Yaya (Puerto Rican and Dominican roots music), Ilú Ayé (Dominican, Puerto Rican, and Cuban roots music), Bámbula (Puerto Rican roots music), and Tato Torres's Yerbabuena (Boricua roots music). Then there are groups like Pa' lo Monte and Kalunga Neg Mawon whose focal point is Haitian-Dominican music; the core of their membership is (or has been) Dominican but has also included Haitians and Puerto Ricans.

Juango Gutiérrez, director of Grammy-nominated plena and bomba ensemble Los Pleneros de la 21, believes that the contemporary youth-led roots music scene in New York City builds on the musical and community-based work of groups like his (founded over two decades and a half ago) and many others. ${ }^{45}$ What he does notice as a distinct difference between his generation and the younger ones is the heightened degree of collaboration and musical hybridization between Dominicans and Puerto Ricans. In the spirit of description and not judgment, Gutiérrez characterizes the prior musical collaborations between Dominicans and Puerto Ricans using the popular aphorism "juntos pero no revueltos" (together but not convoluted), while aptly describing the younger generations' praxis as "juntos y revueltos" (together and convoluted). ${ }^{46}$

While playing in the same groups and hybridizing Dominican and Puerto 
Rican roots musical and spiritual traditions, the younger generations have posed a challenge to the primacy of the nation as the guiding principle in the perpetuation of roots musical traditions (a perpetuation frequently guided by attempts at preserving a static nation-identified "folklore" rather than nourishing living traditions). ${ }^{47}$ Likewise, these younger generations of roots musicians have been self-consciously laboring to break with the blackness/Latinidad dichotomy ${ }^{48}$ New York Dominicans and Puerto Ricans have been reimagining their national and/or ethnic musical traditions by challenging Latino and Latin American Eurocentrism and narrow-minded nationalisms and stressing their connections to the wider African diaspora. In the process, they have also been constructing and reconfiguring social, political, and spiritual alliances and reshaping/reimagining history.

Born and raised in New York City, Alma Moyó's Alexander Lasalle is the child of parents from the town of Moca in the western part of Puerto Rico, a member of a family of bomba practitioners, and a descendant of Haitians who were forced to leave the country by their enslaver after the Haitian Revolution. Evidently, the concept of Haiti as a link or a bridge is more than just poetic collective history to him. But neither is it for many other key players in this New York roots music scene.

Pedro "Único" Noguet, founder of the plena group Capá Prieto, was raised in Mayagüez, the largest town on Puerto Rico's western coast (adjacent to Lasalle's hometown). In a 2004 community forum of bomba practitioners, convened to air out preoccupations and strengthen collective bonds, Noguet replied to a Dominican participant's mention of New York Puerto Rican examples of institution building serving as inspirational models for the New York Dominican community.

My great-grandmother was Dominican. The first time I saw a pandereta used to play salves was in Mayagüez. It's very important that the unity between Dominicans and Puerto Ricans is respected. It's a unity that is centuries old. I'm very interested in emphasizing that. ${ }^{49}$

To Noguet's statement, Ernesto Rodríguez added,

Dominicans and Puerto Ricans are two branches of the same tree. From my Mom's hometown in the Dominican Republic you can see the lights in Mayagüez. When I got to New York, the first community that opened their arms to me were Puerto Ricans. 
This last statement brings us back to Manuela Arciniegas's childhood remembrances of a tight Dominican/Puerto Rican link, based on shared New York City experiences but self-consciously tied by New York-based bomba practitioners to previous historical moments of shared experiences in the Caribbean, such as those centuries-old ones along the western coastal towns of Puerto Rico, particularly Mayagüez. Whereas bomba aesthetics as re-created by Santurce and Loíza-based folkloric groups dominated popular conceptions of bomba for most of the second half of the twentieth century, long-standing efforts to include Mayagüez in bomba's narrative culminated in the prominent inclusion of Don Félix Alduén y Sus Tambores in the 2001 music special Raíces.

Mayagüez and nearby towns and their traditions have served to inspire young researchers/musicians—like Lasalle, Rodríguez, Arciniegas, Noguet, and many others - to investigate and develop further what their ancestors started (and the linkages between them). When I first became a bomba enthusiast in the mid-199os, Mayagüez songs like "Liberté," "Sepúlate," and "Obli Mablé" were not yet part of the bomba "canon"; today, they most certainly are. ${ }^{50}$ Though the exact meaning of the lyrics is still being debated, the Kreyòl origin of many of the terms is agreed on. The most obvious is, of course, the first: liberté is the Puerto Ricanized version of libète (freedom/liberty). Sepúlate, though much less obvious, is said by researchers and practitioners (often one and the same, in the case of the folks featured in this essay) to be possibly derived from c'est pour la tèt (in English, "it's for the head") and has spiritual underpinnings derived from Vodou, where the lwa closest to a devotee is known as the mèt tèt (in English, "owner of the head" or "master of the head").51

The song "Mwe Ale" is an original composition by Osvaldo "Bembé" Lora and Niko Laboy of Ilú Ayé, a group founded in 2004 that gathers some of the best young New York Puerto Rican and Dominican percussionists and singers. The group performs both sacred and popular genres such as plena and bomba from Puerto Rico; palos, salves, and congos from the Dominican Republic; and batá, güiro, and rumba from Cuba. The lyrics to "Mwe Ale," a remix of Kreyòl into Caribbean Spanish and set to a bomba cuembé, are a poignant homage to the town of Mayagüez as a meeting point for Puerto Ricans, Dominicans, and Haitians. The first part of the chorus is in Kreyòl: "mwe ale, mwe ale" (I'm going, I'm going). The second part is in Caribbean Spanish: "pa' Mayagüez" (to Mayagüez).

Ironically, Haiti-the much-maligned blackest country of the Caribbean in the imperial/racist imagination, the one that has fueled what Halbert Barton has termed the "voodoo-phobia" 52 against bomba—has become the bridge that con- 


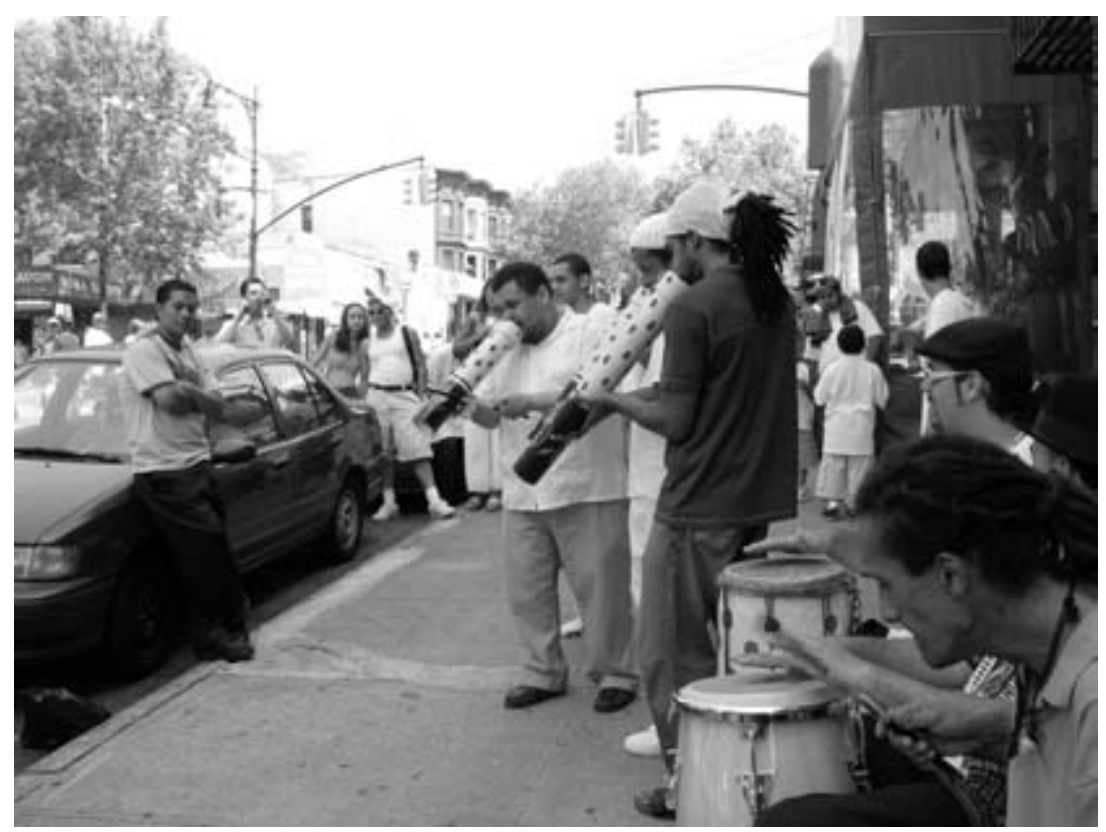

Members of Kalunga Neg Mawon, Alma Moyó, and other musicians play gagá in Sunset Park, Brooklyn, at a 2005 street BBQ and jam in solidarity with the Acosta family, brutalized by police officers two years earlier. Playing a fututo (vaccine) on the far left is José Figueroa. Drumming and wearing sunglasses is Alexander Lasalle. Drumming in the foreground is Ernesto Rodríguez.

nects New York Dominican and Puerto Rican musicians to each other. Haiti is also the mythical bridge that connects New York Caribbean Latinos to the blackness within. In a conversation regarding the same ideas I am elaborating here, Alexander Lasalle perceptively described his generation's hunger to connect to Haitian traditions as a modern-day equivalent of the inspiration drawn from the Haitian Revolution by African descendants all throughout the Americas.

In the book Esclavos rebeldes, the author said that a lot of black Puerto Ricans saw Haiti and the Dominican Republic as the freedom land and almost heavenlike. And that's the same concept among the Haitians when they speak about Guinee. Guinee for them is like heaven, but not like the actual country Guinea. It's what they remember as being beautiful and free and good. That's why when they speak of heaven, they speak of Guinee. ${ }^{53}$ 
In the same conversation, Manuela Arciniegas added the poetic clincher to Lasalle's statement: "Everybody keeps pointing somewhere else as heaven. Its like heaven is the stop on the slave ship before this one." ${ }^{54}$ Thus, Haiti-today as yesterday-serves as a mythical bridge between matter and spirituality, between the outside world and the universes within, and between Afrodiasporic populations of the Spanish-speaking Caribbean who refuse to let their blackness be steeped in the bleaching waters of Latino self-denial.

\section{Notes}

1. These are not direct quotes but my recollections from that night.

2. Rivera, New York Ricans.

3. See Flores, From Bomba to Hip-Hop; Morales, "Brown Like Me?"; Oboler and Dzidzienyo, "Flows and Counterflows"; Laó-Montes, "Afro-Latinidades." tinidad."

4. Rivera, "Real' Puerto Rican Culture"; Rivera, "Between Blackness and La-

5. The pronoun our functions here less as a familial term and more as a proprietary one.

6. Barton, "Drum-Dance Challenge"; Godreau, "Folkloric 'Others'”; Jiménez Román, "Looking at that Middle Ground."

7. In 2003, Dominican-born singer and cultural activist Nina Paulino-a prominent member of the New York musical community I document here-was one of the black-identified Latinos featured in a groundbreaking New York Times article. See Navarro, "New York's Black Latinos."

8. Laó-Montes, "Afro-Latinidades," 126.

9. For analyses of Guinee/Ginen in Haitian spirituality, see Montilus, "Guinea versus Congo Lands," 163-69; Brown, Mama Lola; Désir, "Vodou," 91-96.

10. Barton, "Challenge for Puerto Rican Music," 69-89; Dufrasne González, Puerto Rico también tiene .. . jtambo!; Torres and Mbumba Loango, "Cuando la bomba ñama ... !"; Dufrasne, "La homogeneidad de la música caribeña"; Álvarez and Rivera, "Bambulaé sea allá."

11. Torres and Mbumba Loango, "Cuando la bomba ñama ... !"

12. There is also a New York-based bomba group, cofounded by Alexander Lasalle and Halbert Barton, called Damba Yaribe.

13. Álvarez Nazario, El elemento afronegroide.

14. For critical reflections regarding cultural praxes and products labeled "national," see Rivera, “'Real' Puerto Rican Culture.”

15. See, for example, Petra Cepeda's interview in Yves Billon's 1991 documentary Salsa Opus 3: Puerto Rico.

16. See ethnomusicologist Luis Manuel Alvarez's comments in the 2001 Banco Popular music special Raíces.

17. Ferreras, "Solo Drumming in the Puerto Rican Bomba," 260-61; Maldonado, "Bomba Trigueña." 
18. For a critical assessment of the Raíces music special, see Ferreras, "Raíces."

19. Godreau, "Folkloric 'Others,'” 182.

20. Barton, "A Challenge for Puerto Rican Music," $71,72$.

21. Godreau, "Folkloric 'Others", 178.

22. Ferreras, "Solo Drumming in the Puerto Rican Bomba," 92.

23. Ibid.

24. Ibid.

25. Modesto Cepeda is one of the sons of Don Rafael Cepeda, the deceased folklorist dubbed "the patriarch of bomba."

26. Barton, "Drum-Dance Challenge," 148.

27. Rivera Marrero, "Provoca la bomba un encendido careo."

28. Godreau, "Folkloric 'Others," 172.

29. Barton, "Drum-Dance Challenge," 29-32.

30. "Sicamá Moyó" is the title of an original bomba composed by Alexander Lasalle and performed by the musical group featured in this section, Alma Moyó. The full chorus is "Sicamá Moyó, que un alma libre traspasa todo" (Raise/wake your spirit/life force because a free soul can transcend anything). Sikama means to "wake up" or "lift" in Kimbundu/Kikongo.

31. Moyó is related to the word mojo as used in the United States.

32. The translation is mine. His actual words were in Spanish: “¡Pa’l carajo la bomba de salón! ¡esto es bomba cimarrona!"

33. See Barton, "Drum-Dance Challenge," 29-32.

34. Maldonado, "Bomba Trigueña." See also Ferreras, "Solo Drumming in the Puerto Rican Bomba," 261: "Women's traditional wide fringed skirt, with their corresponding decorated slips, typical of staged bomba, have given way to informal outfits that minimize fashion and maximize movement. When they are ready to dance they pull clothes from their purses or fitness bags and fasten wrap-around skirts over whatever their outfit happens to be."

35. See Barton, "Challenge for Puerto Rican Music," for an account of the 1990 s rise in Puerto Rico of bombazos, tailored to reintroduce bomba (originally a community event, later folklorized for the stage) to the streets.

36. Ruth Fernández, incidentally, is from the southern town of Ponce.

37. Ferreras, "Solo Drumming in the Puerto Rican Bomba," 262-63.

38. I developed this idea in a three-part series, "Elogio de la bomba de Nueva York," published in Claridad, October-December 2004. A version in English, "In Praise of New York Bomba," was printed in the magazine Güiro y Maraca and is available on the Web.

39. Quoted in Rivera, "Elogio de la bomba de Nueva York 3."

40. I was told by a bomba practitioner who asked to remain anonymous, "You know, body movements are, to a certain point, involuntary ... If people, especially our youth, is mixing in bomba with rumba and hip hop it's because these are often the maternal language, the principal language, that their bodies speak" (quoted in Rivera, "In Praise of New York Bomba").

41. Salvador E. Ferreras subscribes to the "le rose" theory: "It is believed that its name is a contraction of the French 'le rose,' the circle formation dancers once assumed when performing its steps" (Ferreras, "Solo Drumming in the Puerto Rican Bomba," 117). 
42. Percussionist Ernesto Rodríguez grew up between the Dominican Republic and New York City. A year or so after this 2005 performance, he left Alma Moyó and cofounded the Haitian/Dominican roots music group Kalunga Meg Mawon.

43. Manuela Arciniegas, personal communication, 2005.

44. www.almamoyo.com/wedo (accessed March 5, 2008).

45. Juango Gutiérrez, personal communication, 2005.

46. Ibid.

47. Barton, "Challenge for Puerto Rican Music"; Barton, "Thousand Soberaos"; Rivera, “'Real' Puerto Rican Culture."

48. This is certainly not to discount the internal debates within this generation, though, in practice, there is a high degree of musical and dance hybridization; debates regarding how much is too much abound.

49. These are not direct quotes but my recollections from that night.

50. "Obli Mablé" and "Liberté" are included in the 2006 album ¡Candela! (Casabe Records).

51. Alexander Lasalle, personal communication.

52. Barton, "Drum-Dance Challenge," 139.

53. Alexander Lasalle, personal communication, 2005.

54. Manuela Arciniegas, personal communication, 2005.

\section{Bibliography}

Álvarez, Luis Manuel, and Angel Quintero Rivera. "Bambulaé sea allá: La bomba y la plena.” 2001. www.tradicionmusical.com/pdf/compendio_final.pdf.

Álvarez Nazario, Manuel. El elemento afronegroide en el español de Puerto Rico. San Juan: Instituto de Cultura Puertorriqueña, 1974.

Barton, Halbert E. "A Challenge for Puerto Rican Music: How to Build a Soberao for Bomba." Centro 16, no. 1 (Spring 2004): 69-89.

Barton, Halbert E. “The Drum-Dance Challenge: An Anthropological Study of Gender, Race and Class Marginalization of Bomba in Puerto Rico." PhD diss., Cornell University, 1995.

Barton, Halbert E. "A Thousand Soberaos: CICRE and the Bombazo Movement." In Cultural (con)Fusion? [Transcaribbean Performance and Performers] Simposium IV, edited by Lowell Fiet and Janet Becerra, 35-47. Rio Piedras, Puerto Rico: Caribe, 2000.

Brown, Karen McCarthy. Mama Lola: A Vodun Priestess in Brooklyn. Berkeley: University of California Press, 1991.

Désir, Dowoti. "Vodou: A Sacred Multidimensional, Pluralistic Space." Teaching Theology and Religion 9, no. 2 (April 2006): 91-96.

Dufrasne, J. Emmanuel. "La homogeneidad de la música caribeña: Sobre la música comercial y popular de Puerto Rico." PhD diss., University of California, Los Angeles, 1985.

Dufrasne González, J. Emanuel. Puerto Rico también tiene .. . jtambó!: Recopilación de artículos sobre la plena y la bomba. Rio Grande, Puerto Rico: Paracumbe, 1994. 
Ferreras, Salvador. "Raíces: New Roots, New Routes." Presented at the Society for Ethnomusicology annual conference in Tucson, AZ, November 5, 2004. www.salferreras.com/writings/Raices.doc.

Ferreras, Salvador. "Solo Drumming in the Puerto Rican Bomba: An Analysis of Musical Processes and Improvisational Strategies.” PhD diss., University of British Columbia, 2005.

Flores, Juan. From Bomba to Hip-Hop. New York: Columbia University Press, 1999.

Godreau, Isar P. “Folkloric 'Others': Blanqueamiento and the Celebration of Blackness as an Exception in Puerto Rico." In Globalization and Race: Transformations in the Cultural Production of Blackness, edited by Kamari Maxine Clarke and Deborah A. Thomas, 171-87. Durham: Duke University Press, 2006.

Jiménez Román, Miriam. "Looking at that Middle Ground: Racial Mixing as Panacea." In A Companion to Latina/o Studies, edited by Juan Flores and Renato Rosaldo, 325-36. Malden, MA: Blackwell, 2007.

Laó-Montes, Agustín. "Afro-Latinidades: Bridging Blackness and Latinidad." In Technofuturos: Critical Interventions in Latina/o Studies, edited by Nancy Raquel Mirabal and Agustin Laó-Montes, 117-40. Lanham, MD: Lexington Books, 2007.

Maldonado, Melanie. "Bomba Trigueña: Diluted Culture and (Loss of) Female Agency." In Caribbean without Borders: Literature, Language, and Culture, edited by Dorsia Smith, Raquel Puig Ramos, and Ileana Cortés Santiago, 95-117. Newcastle, United Kingdom: Cambridge Scholars Publishing, 2008.

Montilus, Guerin C. "Guinea versus Congo Lands: Aspects of the Collective Memory in Haiti." In Global Dimensions of the African Diaspora, edited by Joseph E. Harris, 163-69. Washington, DC: Howard University Press, 1982.

Morales, Ed. "Brown Like Me?" The Nation Online Edition, February 19, 2004. http://www.thenation.com/doc.mhtml?i=20040308\&s=morales (accessed March 5, 2008).

Navarro, Mireya. “For New York's Black Latinos, A Growing Racial Awareness.” New York Times, April 28, 2003.

Oboler, Suzanne, and Anani Dzidzienyo. "Flows and Counterflows: Latinas/os, Blackness, and Racialization in Hemispheric Perspective." In Neither Enemies nor Friends: Latinos, Blacks, Afro-Latinos, edited by Suzanne Oboler and Anani Dzidzienyo, 3-35. New York: Palgrave Macmillan, 2005.

Rivera, Raquel Z. "Between Blackness and Latinidad in the Hip Hop Zone." In A Companion to Latina/o Studies, edited by Juan Flores and Renato Rosaldo, 351-62. Malden, MA: Blackwell, 2007.

Rivera, Raquel Z. "Elogio de la bomba de Nueva York." Claridad, October 21-27, 2004.

Rivera, Raquel Z. "Elogio de la bomba de Nueva York 2: 'La diáspora contrataca.'” Claridad, November 18-24, 2004.

Rivera, Raquel Z. "Elogio de la bomba de Nueva York 3: Tradición ¿y con qué se come eso?" Claridad, December 23-29, 2004.

Rivera, Raquel Z. "In Praise of New York Bomba." Güiro y Maraca, 2005. http://blog.my space.com/index.cfm?fuseaction $=$ blog.view \&friendID $=80291013 \&$ blogID $=20531623$

7. 
Rivera, Raquel Z. New York Ricans from the Hip Hop Zone. New York: Palgrave Macmillan, 2003.

Rivera, Raquel Z. "Will the 'Real' Puerto Rican Culture Please Stand Up? Thoughts on Cultural Nationalism." In None of the Above, edited by Frances Negron-Muntaner, 219-33. New York: Palgrave Macmillan, 2007.

Rivera Marrero, Mildred. "Provoca la bomba un encendido careo." El Nuevo Día, October 11, 2004.

Torres, Carlos "Tato," and Ti-Jan Francisco Mbumba Loango. "Cuando la bomba ñama ... !: Religious Elements of Afro-Puerto Rican Music." Manuscript, 2001. 


\title{
Talking Drums: Soca and Go-Go Music as Grassroots Identity Movements
}

\author{
DEIDRE R. GANTT
}

\section{INTRODUCTION: THE PEOPLE'S MUSIC}

Soca music is a fast-paced derivative of calypso. Its name is derived from Lord Shorty's self-described mission to find the "soul of calypso." It was created in the 1970 s by the calypsonian Garfield Blackman, better known as Lord Shorty or the "Father of Soca," who "began experimenting with East Indian rhythms, using instruments such as the dholak, tabla and dhantal and fusing them with the calypso beat." ${ }^{2}$ The Indian influence in soca faded out fairly early in the genre's development, resurfacing in the last decade as soca gave birth to new forms such as the hybrid chutney-soca. ${ }^{3}$

Like calypso, soca is closely linked to the Trinidadian Carnival, or "mas" (short for masquerade). Other common features between the two genres include a lead singer; sometimes a duet and, more rarely, a group of vocalists; and a lyrical emphasis on sexuality and double entendre. Soca tends to forgo its predecessor's frequent political commentary in favor of "fete music" — party anthems associated with the annual carnival season. Dudley identifies another distinction between the forms: "The [soca] vocal line is very sparse in comparison with traditional calypso. The denseness of syllables and the storytelling style of text have given way to short, crisp phrases that function more like instrumental riffs than narrative."

Around the same time that Lord Shorty was experimenting with calypso, Washington, DC-based guitarist and bandleader Chuck Brown was creating another unique sound: go-go music. Go-go historians Kip Lornell and Charles 
C. Stephenson, Jr., write that Brown—affectionately known as the "Godfather of Go-Go"-began experimenting with this new sound as early as 1971; however, they consider his 1974 and 1975 live shows as the turning point when the new sound emerged. ${ }^{5}$

Go-go music is distinguished from all other forms by the go-go beat, often called a "pocket." The beat is described by Lornell and Stephenson as a polyrhythmic, "syncopated, dotted rhythm that consists of a series of quarter and eighth notes ... which is underscored most dramatically by the bass drum and snare drum, and the hi-hat. This basic rhythmic unit is ornamented by other percussion instruments, especially the conga drums, timbale, and handheld cowbells."

The live show environment is a central factor in both the development and naming of go-go. While playing cabarets to predominately African American audiences in Washington, Brown recognized the need to compete with disco DJs, who "could keep the dance floor packed" and led partygoers to dislike the "pause in between songs." According to Lornell and Stephenson, "Brown replied in kind, performing non-stop with the percussion section keeping the beat, playing the funk, until the band grooved into the next selection."8 This performance strategy led to the name go-go, derived from the Smokey Robinson song "Going to a Go-Go," to characterize the sound that goes and goes and goes. ${ }^{9}$

While soca and go-go began as primarily aesthetic movements by individual musicians, both genres were rapidly popularized by working-class and poor Trinidadians and Washingtonians of African descent. Despite differences in location and sound, soca and go-go music share a common project: an attempt by these populations to negotiate and express their African heritage and to revise, affirm, and project their collective cultural identities. The specific nature of each population's project is closely linked to their historical and contemporary situations-Trinidad's as an essentially biracial, formerly colonized, developing nation and DC's as a predominately black nonstate that happens to also be the capital city of the world's superpower.

\section{A COMMON HERITAGE}

Due to the numerical majority of Africans in slavery-era Trinidad and differences between the repressive practices of American and French slaveholders, Africans in Trinidad were much more successful than their American counterparts in preserving connections to African culture. This has resulted in a direct 
connection of soca to African music practices. This lineage extends back in time to calypso, cariso, the calenda (drum-based songs and dances that accompanied the stick fights of the nineteenth-century "jamette" Carnival as celebrated by Afro-Trinidadians following emancipation), and earlier genres like the jhouba and belair. ${ }^{10}$ When the British banned drumming after seizing control of Trinidad from the Spanish, Trinidadian ingenuity maintained the link through innovations like the tamboo bamboo, a stick drum cut from bamboo canes. ${ }^{11}$

In the United States, including, of course, Washington, DC, along with Virginia and the Carolinas, from which many current black Washingtonians trace their immediate roots, the white establishment stripped the African minority of visible manifestations of African cultural practices. Yet many so-called African music practices clearly survived due to what Olly Wilson calls "shared conceptual approaches to the process of music-making" in the absence of clearly inherited techniques. ${ }^{12}$

The African strategies found in go-go music are also derived from interactions with Caribbean and South American residents of the Washington area, whose cultures had retained African music styles through more concrete methods. Chuck Brown was inspired to add conga drums and timbales to the go-go sound from his stint with Los Latinos, an Afro-Latin band with whom he had played prior to forming the Soul Searchers. ${ }^{13}$ The influences of Afro-Latin and Afro-Cuban music was not, of course, limited to the Washington area but was present throughout American society, particularly in the 1940s through the 1960s. ${ }^{14}$

In the 1970s and 1980s, ideologies of cultural nationalism and Afrocentrism spread throughout Washington's black population. Go-go musicians, audiences, and students responded to this movement by emphasizing the connection between go-go and African music. This tendency was shown most clearly in Straight Up Go-Go, a 1992 documentary, in which Howard University professor Dr. Elias Jones states, "[Go-go] reminded me of Africa, it reminded me of the Caribbean, and it was one of the strongest elements of African presence that I felt in Washington, DC." In the same film, go-go drummer Jason Lane describes the sound as "punk, rock, mostly African," and a fan, Brian Knight, says, "It's kind of like the original beat from Africa." Music critic and writer Nelson George compares go-go to the music of Fela Kuti, while music teacher and gogo drummer Mamadi Nyasuma connects the music to the agogo bell and the wa wa ko rhythm of West Africa. ${ }^{15}$

Whether inherited through direct and literal or conceptual and symbolic methods, soca and go-go share three common strategies of African music- 
making: polymetric ensemble drumming, call-and-response between performers and the audience, and the use of repetitive lyrics that appear in multiple songs performed by multiple artists over a long period of time (years). These strategies have specific applications in the larger project of communal identity formation and expression that these communities have undertaken.

First, the ensemble drumming embodies the process of negotiating multiple identities that characterize both the Afro-Trinidadian and black Washingtonian experience within their cultures. As Nyasuma notes, "The African rhythm was polyrhythmic: all the drums were saying different things but they had to be in sync with one another." ${ }^{16}$ Describing the uses of call-and-response, Jeff Pressing states that "where the response does not copy the call, the response typically has an invariant form and involves several to many singers or instruments, whereas the call is often solo and is more likely to feature substantial variation and improvisation." 17 This is certainly true of its function in soca and go-go, in which artists employ call-and-response to engender both vocal and physical interplay between the musicians and audience members, transforming the fete and the go-go into sites of co-creation, where all members are united in performing their shared identity. The use of repeated phrases and themes creates a "script" of sorts, a blueprint for transmitting the shared identity through time and space. J. C. Roederer writes,

Repetition ... limits the burden on memory, achieves intensification of engagement and attention, and promotes automaticity. This heightens the groove's potential for emotional impact, reinforcing the power of imposed communal rhythms to establish behavioral coherence in masses of people. ${ }^{18}$

The descendants of African slaves in Trinidad and Washington have inherited and adopted common modes of expression; however, the sociopolitical experiences of working-class Trinidadians and Washingtonians are distinct. Thus, the cultural identities being expressed and defined through these tactics are very different and very specific to members of these groups. This helps to explain why each style is highly popular in its region of origin, while being relatively invisible in the mainstream.

\section{SOCA AND THE TRINIDADIAN IDENTITY}

It is no accident that soca music emerged from calypso roughly a decade following Trinidad's independence from Great Britain. Though connected to ear- 
lier Afro-Trinidadian music styles, traditional calypso emerged in the wake of the Arouca riots and general repression by the British colonial government at the turn of the twentieth century. ${ }^{19}$ Calypso became what the former prime minister Eric Williams termed the "mouthpiece" of Afro-Trinidadian political sentiments. ${ }^{20}$

With the end of British rule over the island, Trinidadians found themselves at a crossroads, having to undertake the formidable task of forming a new national identity. Keith Warner documents extensively the calypsonians' continued role as social critics during the formative years of the People's National Movement. But he also demonstrates calypso's ideological shift toward goals stated in 1962 by Williams, then prime minister: that there could be "no Mother Africa for those of African origin ... no Mother England, and no dual loyalties," for "the only Mother we recognise is Mother Trinidad and Tobago." 1

Then, as now, this newly independent country was fundamentally biracial. Trinidadians of African and East Indian descent make up nearly equal percentages of the population; together, they form the country's majority. ${ }^{22}$ Cowley documents the long-standing practice of the British to use "divide-and-rule" tactics on the Afro-Trinidadians and the East Indians who had been brought to Trinidad as indentured servants following emancipation. ${ }^{23}$ Thus, working out new power relations in the absence of the British became of utmost importance. Lord Shorty's experimental fusion of calypso and Indian music is an artistic reflection and extension of this project. The drums that talk to one another in soca are polyrhythmic not only in the number of distinct beats being played but in the synthesis of African and Indian culture into one Trinidad.

Today, soca music makes frequent reference to the need for multiethnic unity among Trinidadians. Here, the technique of repetition finds its strength. These appeals crop up in song after song, as if to drum the concept into the minds of listeners. In "Soca or Die," Destra Garcia, one of Trinidad's most popular soca artists, sings, "It could be so easy if we were divided / all together as one, but yet we so damn divided," calling attention to the unfinished nature of Trinidadian unity and, by implication, the need to keep it in the forefront of the people's minds. Calls for unity permeate Destra's catalog, but she is far from the only artist to employ this technique. Tribe, one of Trinidad's largest mas bands (as in a posse of revelers rather than a musical ensemble), bills itself as "all-inclusive." ${ }^{4}$ Iwer George, the 2007 Soca Monarch (champion of the annual Carnival soca competition), titled one of his songs "Time to Unite." In one performance during 2006 mas, Machel Montano called for everyone to jump: black, white, Indian, or Chinese. ${ }^{25}$ 
This so-called festival soca has been widely criticized for its lack of socially conscious lyrics and its emphasis on jumping, wining, and waving rag and flag. In the documentary Calypso at Dirty Jim's, the famous calypso pioneer Calypso Rose accuses the modern soca singers of "assassinating calypso," due to the highly repetitive nature of many soca tunes. (Soca is not without its "message" songs, however, although they are less common and often less direct than those found in traditional calypso.)

However, these seemingly redundant instructions use call-and-response to reinforce the message of unity. Singer after singer instructs the audience to move together as a unit— to jump up, wave, "get on bad." In the performance of shared activity-particularly within a context of fun-the identity project strives to make the sung unity real, even if only while playing mas. In this way, Trinidadians are once again redefining Carnival. Just as the jamettes overtook the celebration from the French upper classes a century ago, using it to critique their enslavers and, when merged with Canboulay, to celebrate their freedom from bondage, ${ }^{26}$ today's Trinidadians are reinterpreting Carnival as a celebration open to all Trinidadians.

\section{GO-GO MUSIC AND THE WASHINGTONIAN IDENTITY}

Like soca, go-go music emerged in the wake of Washington, DC's, acquisition of limited political home rule. Article 1, Section 8, Clause 17 of the U. S. Constitution effectively made Washington a colony of the United States. Until 1961, residents of the capital city did not even have the right to select delegates for the electoral college that elects the president and vice president of the United States. ${ }^{27}$ Two years before Chuck Brown and the Soul Searchers developed gogo's seminal sound, the situation changed somewhat when Congress passed the District of Columbia Home Rule Act of 1973, granting Washington's residents (eight hundred thousand at the time) the right to elect a mayor and city council representatives. ${ }^{28}$

To this day, however, DC residents do not have a voting member of Congress, nor do they enjoy the same level of self-governance taken for granted by residents in any of the fifty states. Congress must approve the city's budget and legislation passed by its elected officials; it also has the power to revoke home rule, as it proved in 1995 when it appointed a financial control board to assume responsibility for major decisions that were formerly the province of elected city officials. ${ }^{29}$

This federal-local schism extends beyond governance into the daily lives of 
Washington's residents. As noted in the go-go documentary The Pocket, there is, on the one hand, Washington the federal city, which is powerful, wealthy, controlled by whites, and extremely visible around the globe. On the other hand, there is DC, which is politically powerless, economically deprived, predominately black, and utterly invisible to the millions of tourists who flock to the city to see the government buildings, monuments, Smithsonian museums, and cherry blossoms - invisible except, that is, during televised reports of drug trafficking, violence, or other social mayhem.

This aspect of Washington's history and social conditions played an important role in the rise of go-go music. The liner notes of the early go-go compilation album Go-Go Crankin: Paint the White House Black demonstrate the selfawareness of go-go in this regard.

Cut through the razzmatazz - the White House, Lincoln Memorial, a thriving tourist industry - and outside the golden mile the heritage is one of mass unemployment and widespread unrest creating a tension that must be channeled before it explodes. Go Go is the creative force born to absorb the anger. Go Go music is functional. It is a hard-hitting percussion-led punch that reflects the audience's "say it loud and say it proud" stance.

Thus, the fundamental identity project of go-go music is to affirm the presence of Washington's invisible black community. Washington Post journalist Jill Nelson calls go-go "Washington's most unique personality ... the African American community's, musically, way of saying 'this is something that is intrinsically ours. " 30 Like soca, go-go employs the techniques of polyrhythmic drumming, call-and-response, repetitive themes, and "shout-outs" to achieve its purpose.

A go-go song can last anywhere from five to fifteen minutes and is generally structured in one of three ways: as an original composition, a "go-goized" cover of an existing song, or a "suite" in which the band combines verses and choruses from two or three songs that are similar in theme or genre. Go-go bands' reliance on popular music subjects them to intense criticism by those in the Washington metropolitan area (and beyond) who consider the majority of gogo bands to lack originality and musicianship. (Like the critiques of soca, this point often overlooks the numerous original compositions performed each year by go-go bands. However, in both cases, repetition and covers tend to dominate the popular play lists.)

The tradition of covering mainstream hits stems from go-go's origins as Top 40 cabaret music and from Chuck Brown's own self-described limitations as a 
songwriter. ${ }^{31}$ As the genre's pioneer, his focus on writing hooks rather than narrative-driven lyrics has undoubtedly influenced later bands. Nevertheless, gogo's heavy use of popular music does not automatically indicate a lack of creativity among band members. Wilson and Alroy's Record Reviews calls go-go "an extraordinarily supple form: you can play anything from an MOR ballad to a car commercial over a go-go beat and make it danceable."32 In setting popular music to a go-go beat, the polyrhythms - timbales, congas, rollatoms, trap set, and hand percussion in the form of cowbells and tambourines-not only speak to one another but create a space for black Washingtonians within the wider American culture of which they are a part (but not a part, at least politically).

Brown also developed the strategy of revising the lyrics of an existing song to give them a hometown flavor, as demonstrated in his signature renditions of a Duke Ellington classic as "It Don't Mean a Thing, If It Don't Have the Go-Go Swing" and of Harry Belafonte's "Day-O," which removes listeners from the setting of a banana boat and places them in the nightclub, where "daylight come, we don't wanna go home."33 Go-go bands have followed suit, reinterpreting songs from nearly every American genre: rap, funk, classic R\&B, reggae, jazz, rock, alternative, gospel, even TV theme shows and commercials. In 2006, L!ssen Band used this strategy to adapt a Boost Mobile television commercial into a boast of citywide support: "Northeast, Northwest, Southeast, Southwest, Where they at, the whole city behind us." ${ }^{34}$ This is an example of the "display" aspect of go-go music, which will be discussed shortly. Today's fans come to the go-go expecting to hear their favorite band give popular songs a "DC sound."

From the beginning, go-go was a participatory form of music. Between sets, Chuck Brown began greeting audience members by name. Soon this became a cornerstone of the go-go experience, and as the music spread through Washington's black neighborhoods, it came to be known as the "display." Contemporary go-go songs commonly start or finish with a lead talker greeting members of the audience, often calling out neighborhood crews (mostly males) and "honnie cliques" (groups of females who may or may not be affiliated with the male crews) or interacting with the crowd over a pocket beat. Steven "Bugs" Herrion, the lead talker of Junkyard Band states,

We can live without the call and response, but sooner or later, the crowd's going get into it, and want to say something. That's just the energy that comes from them. They wanna say, "Oh say my name. Say my name. Put me on display." People love to, you know, be known, you see. Let the crowd know they in the house, you know. "I'm over here." So, that's going automatically come. ${ }^{35}$ 
The display strategy is fundamental to go-go's soaring popularity. The practice places the dispossessed and invisible members of DC's poorer communities on the map, if only among themselves. Go-go songs are full of names that are intelligible only to people who are knowledgeable about DC street life: Nu Projects, Third World Honeys, E Street Bangers, 14th and Up (short for Uphsur Street), KDY (an abbreviation for Kennedy Street) and 640-the address of a housing project on northwest Hobart Street where the "bad boys of go-go," Backyard Band, grew up. Eventually, these displays grew to include neighborhoods and crews from bordering Prince George's County in Maryland as well.

Like soca, go-go music features certain repetitive themes that function as both call-and-response and an in-group script. If you are part of the go-go community, you know that you are supposed to say, "Wind me up, Chuck," to bring the Godfather on stage. When a band says, "Where y'all from?" you are supposed to scream your sector of the city-Northeast, Northwest, Southeast, or Southwest-or your specific neighborhood or crew. If a band member sings, "I've got that feelin, that funky feelin," and sticks a mike in your face, you know to say, "[insert band name] is in the house and they're ready to roll." These and other scripts are recycled from band to band and from generation to generation; they serve to unify and preserve the traditions that have emerged out of go-go's history of more than thirty years.

\section{CONCLUSION: IS AH WE TING ... YOU WOULDN'T UNDERSTAND}

In closing, the Trinidadian identity project as expressed through soca can best be summed up with the common West Indian phrase "Is Ah We Ting." Soca music's open-arms stance is a by-product of Afro-Trinidadian security and strength, relatively speaking, as co-creators of a new, independent national identity with a culture worthy of exportation. By contrast, the defensive, selfaffirming posture of go-go music can be summarized by a similar African American slogan from the early 1990s: "It's a Black Thing"-in this case, a black DC thing-_You Wouldn't Understand."

Both genres have a long way to go in gaining respectability, both among the upper classes of Trinidad and Washington and in the larger music cultures beyond their regions. Soca-and Carnival—has spread throughout the Lesser Antilles, a fact that makes Trinidadians extremely proud. Carnival, pan, and calypso represent what several writers refer to as the trinity of Trinidadian cultural achievements. ${ }^{36}$ As Trinidadians and other eastern Caribbean natives have 
immigrated to the United States, the United Kingdom, and Canada, they have exported Carnival beyond the Caribbean, albeit in a somewhat diluted, PanCaribbean fashion. But this, too, is part of the Trinidadian project, stretching back to the days of the West Indian Federation on up to CARICOM and attempts to forge a Pan-Caribbean identity. ${ }^{37}$ Soca is at the forefront of this movement, with Destra's appeals to Caribbean "massive," Nadia Batson's tune "One Island," Patrice Roberts's "Come to the Islands," and Barbadian Alison Hinds's song "Wine Meh."

Yet Trinidad's soca artists still struggle for regular airplay after Carnival, leading many to tour extensively in the months between the end of Carnival and the beginning of the next season. Critics such as Bukka Rennie accuse fete soca of being one more instance of the commercialization and mass marketing of Carnival as well as a takeover by middle-class interests. In 2005, for example, the Trinidad and Tobago government invested ten million U.S. dollars into Carnival celebrations. This reaped a benefit of $\$ 150$ million for the economy as a whole, which was estimated at $\$ 13-18$ billion in $2005 .{ }^{38}$ The government naturally seeks to capitalize on Carnival in order to drive tourism to the island and raise its profile among nations. Soca's "golden child" status is temporary, however, and closely connected to the annual influx of Carnival dollars from December to February into the national income. ${ }^{39}$

Unlike Trinidad, Washington has a natural tourism draw and does not need the go-go economy. Initially, the city's most popular stations would not play gogo at all. While a few record labels—Sugar Hill, Island, and Def Jam-flirted with the DC sound in the early 1980s, go-go has yet to break out of the Washington area in any substantial way. ${ }^{40}$ Additionally, as DC leaders seek to eliminate the city's old "murder capital" image and attract more affluent development and residents, go-go's close relationship with DC's ghettoes and projects has made the genre an easy target for the news, city administrators who want to appear tough on crime, and the white and black middle class who make up their primary audience and constituent base. Certain fans have made it harder for go-go music to survive by starting fights or worse-wounding or killing people in or near go-go clubs. Lornell and Stephenson and many other defenders of go-go emphatically point out that this violence usually does not take place inside the clubs. But when a police officer was killed inside the IBEX nightclub in 1997, the city shut the club down, starting a trend that has pitted city officials against the go-go community.

Two grassroots organizations, the Go-Go Coalition and Peaceoholics, have successfully mobilized band members, industry staff, and go-go supporters to 
protest club closings. They have also organized community conferences on public safety at go-go clubs and pro-peace go-go concerts and have advocated special security measures, including ID cards, to track attendees and remove troublemakers from the premises. ${ }^{41}$ As go-go music matures, it is slowly breaking out of the "local hood flavor" box it has been trapped in. Go-go bands have been used at health fairs, HIV awareness events, and fund-raisers for Hurricane Katrina victims. Gospel go-go has also begun to grow in popularity. In the last five years, Chuck Brown has been embraced as a hometown hero by local leaders, and mainstream urban-format radio stations have created evening go-go programming. True to its name, DC's homegrown music keeps going and going and going.

Pressing notes, "Once musical effects attain a certain currency, they form part of a cultural evolution, which proceeds nongenomically from generation to generation." ${ }^{42}$ Through the use of polyrhythmic drumming, call-and-response, repetition, and display, both soca and go-go seek to make this evolution real in the lives of its listeners and the cultures to which they belong. In this respect, soca and go-go are included in what Pressing calls "relatively complex creative adaptations of traditional African and African diasporic rhythmic techniques [which] are a natural consequence of a culture of questioning and reflection that encompasses maintenance of historical reference and accommodation to innovation." ${ }^{43}$ Using this framework, I have sought to rescue both genres from their stigmatization as mindless party music or uninspired bucket beating.

\section{Notes}

1. Warner, Kaiso! The Trinidad Calypso, 21.

2. National Library, "Calypso: Subject Guide."

3. Dudley, "Judging by 'The Beat,"” 287.

4. Ibid., 294.

5. Lornell and Stephenson, The Beat, 23.

6. Ibid., 12.

7. Ibid.

8. Ibid.

9. Ibid.

10. Cowley, Carnival, Canboulay, and Calypso, 14 .

11. Inside Trinidad and Tobago Carnival.

12. Wilson, "It Don't Mean a Thing," 154.

13. Lornell and Stephenson, The Beat, 25.

14. Ibid., 12. 
15. Ibid.

16. Ibid.

17. Pressing, "Black Atlantic Rhythm," 304.

18. Quoted in ibid., 290.

19. Cowley, Carnival, Canboulay, and Calypso, 124.

20. Quoted in Warner, Kaiso! The Trinidad Calypso, 59.

21. Quoted in ibid., 82.

22. Dudley, "Judging by 'The Beat," 286.

23. Cowley, Carnival, Canboulay, and Calypso, 56.

24. Inside Trinidad and Tobago Carnival.

25. Ibid.

26. Cowley, Carnival, Canboulay, and Calypso, 20, 33.

27. "DC Voting Rights Historical Timeline."

28. Ibid.

29. Martin, "Q \& A: The Financial Control Board."

30. Straight Up Go-Go.

31. Chuck Brown, interview on Kato and the TMOTTGoGo Morning Show.

32. Lornell and Stephenson, The Beat, 11.

33. Chuck Brown, Go-Go Live at the Capital Centre.

34. Ibid.

35. The Music District.

36. "Kitch the Legend"; Montano and Garcia, "Carnival."

37. Warner, Kaiso! The Trinidad Calypso, 70.

38. Meschino, "Soca Battles Pirates," 25.

39. Ibid.

40. Lornell and Stephenson, The Beat, 43-44.

41. Go-Go Coalition, http://www.gogocoalition.org; Pierre and Williams, "Pulse of Go-Go," A1.

42. Pressing, "Black Atlantic Rhythm," 298.

43. Ibid., 285 .

\section{Bibliography}

Brown, Chuck. Go-Go Live at the Capital Centre. http://youtube.com/watch?v=huJCN fEbcJk. Streaming video of 1987 performance.

Brown, Chuck. Interview on Kato and the TMOTTGoGo Morning Show, WEIT (Washington, DC), May 21, 2007. http://www.gogoradio.com.

Calypso at Dirty Jim's. Directed by Pascale Obolo. Performers: Bomber, Mighty Sparrow, Calypso Rose. Maturity Music, Ltd., 2005. DVD.

Cowley, John. Carnival, Canboulay and Calypso: Traditions in the Making. Cambridge: Cambridge University Press, 1996.

Dan, Maximus. "Order." 2005.

“DC Voting Rights Historical Timeline.” DC Vote, 2003. http://www.dcvote.org/trellis/ denial/dcvotingrightshistoricaltimeline.cfm. 
Dudley, Shannon. “Judging by 'The Beat': Calypso versus Soca.” Ethnomusicology 40, no. 2 (1996).

Garcia, Destra. "Soca or Die." 2007.

Garlin, Bunji. "Blaze De Fire.” 2005.

Go-Go Coalition home page. http://www.gogocoalition.org.

Inside Trinidad and Tobago Carnival 2006 in Xcess. Advanced Dynamics, 2006. DVD.

Junkyard Band. The Word/Sardines. 12 in. Def Jam Recordings, 1986.

"Kitch the Legend . . . Region Mourns." Trinidad Guardian, February 12, 2000. http://www.tntisland.com/kitch05.html.

L!ssen Band. "The Whole City Behind Us." http://www.youtube.com/watch?v=II WKPxj9mhw. Streaming video.

Lornell, Kip, and Charles C. Stephenson, Jr. The Beat: Go-Go's Fusion of Funk and HipHop. New York: Billboard Books, 2001.

Martin, John P. “Q\&A: The Financial Control Board.” Washington Post, August 7, 1998. http://www.washingtonpost.com/wp-srv/local/longterm/library/dc/control/con trolqa.htm.

Meschino, Patricia. "Soca Battles Pirates of the Caribbean." Billboard, March 19, 2005.

Metropolitan Police Department. "DC's Curfew Law-Know the Facts." http://mpdc.dc .gov/mpdc/cwp/view,a,1237,q,547375,mpdcNav_GID,1549,mpdcNav,\%7C.asp.

Montano, Machel, featuring Destra Garcia. "Carnival." The Xtatik Circus. 2003.

Montano, Machel, and Xtatik, featuring Benjai. “Amnesty (Rah, Rah, Rah).” B.O.D.Y. JW Production, April 20, 2006.

Montano, Machel, and Xtatik, featuring Doug E. Fresh. "We Not Givin Up." The Xtatik Experience. 2005.

The Music District. Directed by Susan Levitas. Performers: Junkyard Band, Kings of Harmony. California Newsreel, 1996.

National Library and Information System Authority of Trinidad and Tobago. "Calypso: Subject Guide.” http://library2.nalis.gov.tt/Default.aspx?PageContentID=186\&tab id $=138$ (accessed February 12, 2007).

Pierre, Robert E., and Clarence Williams. "Pulse of Go-Go, Promise of Peace Mingle at D.C. Dance Event for Youth.” Washington Post, October 16, 2006, A1. http://www .washingtonpost.com/wp-dyn/content/article/2006/10/15/AR200610150 1115.html.

The Pocket: The DC Go-Go Movement. Directed by Nick Shumaker and Michael Cahill. 2002.

Pressing, Jeff. "Black Atlantic Rhythm: Its Computational and Transcultural Foundations." Music Perception 19, no. 3 (2002): 285-310.

Rennie, Bukka. "Jamette Doh Play Jamette." March 1, 2003. http://www.trinisoca .com/articles/2003/0103.html.

Rondeaux, Candace, and Rosalind S. Helderman. "Amid Wave of Killings, Pr. George's Shuts Clubs." Washington Post, March 30, 2007, A1. http://www.washingtonpost .com/wp-dyn/content/article/2007/03/29/AR2007032902550.html.

Sankeralli, Burton. "It's Carnival." Trinidad-Tobago Net. February 22, 2004. http://www .trinidad-tobago.net/Article.aspx?PageId=80.

Straight Up Go-Go. Directed by Shuaib Muhammed Kedar. Progressive Productions, 1992. 
Thomas-Lester, Avis. "Protesters Offer to Be Part of Solution.” Washington Post, March 30, 2007, A1. http://www.washingtonpost.com/wp-dyn/content/article/2007/04/03/ AR2007040301726.html.

Various Artists. Go-Go Crankin: Paint the White House Black. 4th and Broadway, 1985.

Warner, Keith Q. Kaiso! The Trinidad Calypso: A Study of the Calypso as Oral Literature. Washington, DC: Three Continents Press, 1985.

Wilson, Olly. "It Don't Mean a Thing If It Ain't Got That Swing: The Relationship between African and African American Music." In African Roots/American Cultures: Africa in the Creation of the Americas, edited by Sheila S. Walker. Lanham, MD: Rowman and Littlefield, 2001. 


\title{
Warriors of the Word: Rapso in Trinidad's Festival Culture
}

\author{
PATRICIA VAN LEEUWAARDE MOONSAMMY
}

Rapso, "de power of de word in de riddim ${ }^{1}$ of de word," is a genre of lyrically oriented rhythmic performance and music from Trinidad. It is deeply rooted in the traditions of oral culture and resistance associated with Carnival, Trinidad and Tobago's pre-Lenten festival. Yet this genre finds itself positioned precipitously on the edge of Carnival, which, in the popular imagination, constitutes the performances that embody Trinbagonian ${ }^{2}$ identity and nationhood. ${ }^{3}$ In this essay, I explore the ways in which rapso performance and rapso artists exist within the cultural, social, and economic politics of identity and performance in Trinidad and Tobago-politics that are located within and shaped by the aesthetics and business of Carnival. Additionally, attention to rapso performance reveals how an alternative politics of activism can create spaces for reenvisioning individual agency and nation within the sphere of globalized political economies of cultural production.

In Trinidad and Tobago, music is a highly politicized cultural product. It is the subject of debates about foreign cultural imperialism, morality, freedom of expression and censorship, and individual and national identity. It has been a central feature of the nationalist project that, in postindependence Trinidad and Tobago, sought to construct an indigenous identity independent of the cultural hegemony of its former British colonial authority. Calypso was positioned as the musical form most suited to that project. ${ }^{4}$ Although rapso practitioners view their craft as a lyrically foregrounded, activist-oriented variant of calypso, describing it as the poetry of calypso and the consciousness of soca, some have resisted its inclusion under the umbrella of the calypso art form. This serves to 
delegitimize this genre with respect to national culture. Through the following close reading of a rapso performance, I will discuss how rapso artists position themselves in relation to aspects of national culture and create spaces for an alternative vision for the nation and the place of its citizens in the contemporary context of local and global flows of capital and power.

\section{WARRIOR CHANTS AND SONGS OF REVOLUTION}

The vibe at the Pelican Inn that night was unfamiliar to me. Unlike the many Carnival fêtes and concerts that I had attended in Trinidad, this felt more intimate, as though the people present were part of a close-knit community. The patrons at the Pelican Inn that night were truly representative of the ethnic mélange that is Trinidad. There were people of African, Indian, Chinese, and European ancestry of all ages, from young children to the elderly. In the crowd could be seen members of Trinidad's artistic elite and representatives from the media, as well as a solid core of intellectual and creative young adults. A stage was set up in the corner of the patio area, and the venue was filled to capacity, outside, inside, and even on the second-floor balcony overlooking the patio. Those who had arrived early were lucky to find seating in the white plastic armchairs set up in rows in front of the stage or at the wooden picnic tables scattered along the periphery of the patio. Others were standing about or sitting on the ground. Self-consciously, I set up my tripod and video camera, positioning myself next to the cameraman from Gayelle, Trinidad and Tobago's new television station, whose commitment to programming with 100 percent local content was revolutionary. I sought to capture on film that which Edward Schieffelin notes is so elusive: the creation of presence in the performance moment through the interaction between the performer and the audience. ${ }^{5}$ I hoped, somewhat in vain, to record the emotion and spirit of the evening, but settled for what I could accomplish with one camera-one ethnographic gaze.

The night air, though much cooler than it had been even a few hours earlier, was still quite warm, but very comfortable as it enshrouded us under the open Caribbean sky. Sheldon Blackman was in concert to launch his new CD, Re-Loaded. Sheldon's father, the late Ras Shorty I, had been a prolific calypsonian and is recognized as the man who blended elements from classical and devotional Indian music in Trinidad with calypso, a musical genre tracing its roots to Africa, thereby creating soca, which has evolved to become the musical energy that drives and sustains Carnival. But that particular evening was not about soca music or about Carnival. It was about Sheldon's particular brand of 
rapso, Jamoo $^{6}$ rapso, and, more expansively, about alternative music in Trinidad. His music reflected the influences in his life, being indigenous, with a calypso rhythm, but simultaneously international, folksy, and jazzy, with smatterings of rhythm and blues and rock. Sheldon, backed by his multitalented family, sang songs of revolution, songs honoring the beauty of African women, songs of love and spirituality, and songs evoking the Trinidadian land- and seascapes. His music was conscious music, Trinidad-style, with a message of love and transformation.

It was April 28, 2004, a date celebrated in Trinidad and Tobago as the National Day of Rapso. Sheldon's concert was part of a larger program celebrating Rapso History Month. How fitting, then, that Sheldon would acknowledge and respectfully call to the stage the man who embodies the spirit of rapso: the poet, social activist, and educator, Brother Resistance.

In the tradition of the chantuelle, ${ }^{7}$ Sheldon drew Brother Resistance forward through song, chanting a verse and chorus from Resistance's song "Ring de Bell" and priming the audience for an engagement with the charismatic rapso leader's call and response performance style.

C'mon, c'mon brother leader

It's high time that we summon up de power

This time we ring it in de earbell

Look, ah have a story to tell

Well it's a long, long time that we fighting for freedom

Victory bound to come

Assemble de people with sight of de mission

Leh we rock de rapso riddum

The chorus was sung in call and response fashion.

(Call) Ring de bell, ring de bell ... (Response) Ring de Bell

De bell down dey. . . Ring de bell

De bell for culture ... Ring de bell

De bell down dey... Ring de bell

De bell for freedom . . . Ring de bell

De bell down dey. . . Ring de bell

De bell for de rapso riddum ... Ring de bell

De bell down dey... 
Looking toward the rear of the audience, once could see Brother Resistance's signature tall leather hat that contained his floor-length dreadlocks emerge as he made his way through the densely packed crowd to the stage. After embracing Sheldon and greeting the other musicians on stage, he began to sing "Ring de Bell." Midway through the song, he signaled for the volume of the music to be lowered and addressed the audience.

Dis is de spirit of rebellion

De fire dat blaze in de heart of de youth

De sound of pride and determination

In de heartical ${ }^{8}$ search for de truth ... Rapso

Rapso is de attitude as we rock against de colonial order

To create a new vibration for us all in de region ... Rapso

Rapso is de signal dat de struggle ent done, Trinidad and Tobago

You know why?

You know you love jamoo so much and you cyar ${ }^{9}$ hear yuh music on de radio

You cyar see yuh picture on a TV show (well except Gayelle)

So how you want de world to know dat all this beautiful music comin' outta Trinidad and Tobago?

So you see, as Lancelot "Kebu" Layne would always say

Don't believe what foreigners do

Is better than you, because that ent true

Is ah mental block dat hard to unlock

It hard like ah rock and with it you don't work

Yuh go live with illusion ... tryin to be anodda man

So don't believe what foreigners do

Is better than you, because that ent true

And if a man want to set false standards for you to follow

To he, what you say?

(Audience responds) Blow 'Way

What you say

(Audience responds) Blow 'Way

Blow'Way

So I tell you, we all have to come together to fight for our music on de radio Pick up yuh pen an' write. Pick up yuh telephone an' call. 
Let us rally together, Trinidad and Tobago, so we could hear our music on de radio

So your artists and dem could live, and feed dey family, and make more music

By de grace of de most high God, you all have a responsibility

I didn't come here to preach to you all tonight, but I'm telling you

Sheldon Blackman and all these musicians here is anodda generation again!

We cyar wait no more Trinidad and Tobago

Make it your personal pledge

You must fight to get your music on de radio

You will fight against piracy ${ }^{10}$ in dis country? Eh? Yuh sure?

Returning to song, Resistance sang,

And ah ring it and ah ring it and ah ring it and ah ring it

Ring de bell for Marcus Garvey, Malcolm X and Buzz Butler ${ }^{11}$

Ring de bell...

He concluded,

Because we make a music to build bridges across humanity

We make a music to break down de walls dat divide we

May God bless each and every one of you

Stand firm for yuh culture

Stand firm for yuh culture

I want de call and response vibration

De poet and de people

De chantuelle and de band

As he exited the stage, the audience joined him in singing,

Stand firm for yuh culture

Stand firm for yuh culture

When Sheldon Blackman began his introduction of Brother Resistance by singing one of the signature rapso songs, Brother Resistance's "Ring de Bell," he foregrounded the spiritual aspect of a performance environment that already combined artistic, progressive politics with Afro-Caribbean, Rastafarian-in- 
formed Christianity. "Ring de Bell," with its call and response repetition, invoked the spirit of the Spiritual Baptist ${ }^{12}$ preacher, ringing her bell between the rhythmic phrases of her prayers. Brother Resistance extended this performance by picking up the song where Sheldon Blackman had stopped, continuing the singing-chanting of the verses and chorus for several minutes, then shifting the tone of the performance from repetition and chanting to rapso poetry. In the tradition of the rapso artist, he honored the elder, the ancestor Lancelot "Kebu" Layne, ${ }^{13}$ by reciting from his stridently anticolonial song "Blow 'Way."

After honoring the ancestors and calling forth performances of worship and rebellion, Brother Resistance shifted the performance yet again to rapso dialogue, exhorting the audience to be social activists, demand local images in the media, and support local artists. He expressed Pan-Africanist consciousnessthrough references to Marcus Garvey, Malcolm X, and Uriah "Buzz" Butlerand simultaneously expressed the nationalist sentiment to "Stand firm for yuh culture." Embodying rapso authenticity, Brother Resistance had the audience on their feet, with arms raised, dancing to the rhythm of his music and the rhythm of his words. This performance was passionately executed, displaying several of the styles and themes of rapso performance: chants, songs, poetry, dialogue, call and response, and themes of resistance, spiritual independence, self-determination, and activism.

Brother Resistance's activist-oriented rapso dialogue illuminated several aspects of the current state of Trinbagonian cultural politics. That the era of anticolonial/anti-imperial struggle has not come to a close in Trinidad and Tobago is evident, and although the struggle is no longer for independence from direct colonial administrative governance, it continues to take place in the arena of culture, identity, and political economy. The phrase "it's a long, long time that we fighting for freedom" references various historical struggles for freedom in Trinidad and Tobago-freedom from slavery; freedom from colonial domination, from neocolonial (Afro-Saxon) bias for white and/or Western social and cultural forms; freedom from U.S. imperialist control and occupation-as well as contemporary struggles for equality, respect, and social and economic justice. Brother Resistance invoked the spirit of the chantuelle, one of a complex of Trinidadian Carnival figures of resistance, and called the audience to action with his exhortation that "de struggle ent done." This conscious association with local, historical symbols of indigenous strength and warriorhood is an expression of the politics of resistance inherent in rapso performance and activism.

People mistakenly assume that the term rapso is a combination of the words 
rap and soca, but both rapso and soca were evolving from calypso in the 1970 . Soca evolved from Ras Shorty I's experimental blendings of calypso and Trinidadian versions of the traditional music of India. Rapso evolved from calypso also but traces its roots to the oral traditions and masquerade characters of Trinidad and Tobago: the chantuelle, the Midnight Robber and the Pierrot Grenade. The chantuelle sang the praises of a particular stickfighter as he battled against a foe in the gayelle. ${ }^{14}$ The Midnight Robber sang his own praises, weaving long tales of conquest together with descriptions of his fearsome countenance and character. The Pierrot Grenade broke large words down into syllables and told a story about each syllable, bringing the stories to conclusion in an artful and comedic fashion to inscribe in the memory of those present an appreciation for play with words.

All of these traditions and characters express rebellion and assertion of self in the face of cultural, social, economic, or political domination. The chantuelle's boasts of prowess in the stickfighting arena in an era of slavery and European domination were acts of rebellion not only against the institution of slavery, with its laws banning public gathering among slaves, but also against the idea that to be black was to be inferior and powerless. The Midnight Robber's speeches defied not only man but also the forces of nature to dare challenge him in a war of words or might. Indeed, his badness was outright rebellion against any form of containment or limitation, man-made or otherwise, and symbolized the physical and metaphysical power that could be summoned by the oppressed. The Pierrot Grenade attacked the distinction made between Standard English and creolized English by infusing words with new associations that are rooted in local experiences and ways of speaking.

In addition to the legacy of these classic performances of the oral tradition in Trinidad, rapso built on the work of the calypsonian Lancelot "Kebu" Layne. Layne disrupted the musical flow of sung calypso by speaking verses that he felt were especially significant, so that the message would not be lost on the audience, who may be more attuned to the music rather than the words of sung calypso. "Blow 'Way" was written during the turbulent early period of the 1970s Black Power Revolution in Trinidad, when Black ${ }^{15}$ people demanded a revolutionary change in the social and economic order that had been inscribed during colonial rule and that continued to exist after national independence. Rapso was a vehicle of protest, and Lancelot "Kebu” Layne, Brother Resistance, and Brother Book ${ }^{16}$ were some of the rapso chantuelles that were chanting for freedom in the frontlines of the wars for Black rights and workers' rights. 
Cheryl Byron, considered the "Mother of Rapso," was also an important figure in the history of the genre. She took the stylistic practice of Lancelot "Kebu" Layne a step further and broke tradition by performing poetry, rather than singing calypso, within the calypso tent. ${ }^{17}$ An ordained Reverend Mother in the Spiritual Baptist religion, Byron brought African diasporic spiritual consciousness to the calypso tent, a performance arena noted for sexual double entendre and humor, as well as social and political commentary. In contrast to the typically male-performed masquerade characters that signify resistance practice within the Carnival context and that are historical symbols of an ethic of empowering stances in opposition to domination, Cheryl Byron's poetic performances made visible the female acts of anticolonial resistance that were carried out in spiritual and religious practice.

The cultivation of Black consciousness, the inscribing of absent histories, and the fight against social injustice were fundamental aspects of early rapso ideology. It was into this sociopolitical climate that the first wave of rapso artists emerged. Carnival spaces and traditions were reclaimed and reinterpreted as conscious and deliberate acts of self-representation and postcolonial agency. The rhythm of indigenous language, wedded with the emotions of everyday life experiences and the politics and performances of resistance, gave rise to rapso, a unique poetic and musical form. The rapso artist was a warrior of the word, fighting for equality, for consciousness, and for the downpressed. ${ }^{18}$

When rapso artists acknowledge that there is a relationship between rapso and rap and dancehall but assert that rapso did not evolve from those forms, they are rejecting a global ordering of Black performance practices that locate American forms (such as rap and hip-hop) at the center and presume that African diasporic forms such as dancehall and rapso are Jamaican and Trinidadian versions of American rap. They argue that rapso is a musically poetic expression of the Trinidad experience, brought forward in a Trinidadian voice. The self-pride that comes from using one's own voice, of stamping artistic expression indelibly with one's own identity, is a fundamental tenet of the rapso practice. Rapso is "de power of de word in de rhythm of de word" and affirms Trinidadianness.

Stephanie Sadre-Orafai writes that "language is the ultimate site of authenticity for rapso," 19 yet as I have argued, rapso authenticity is equally defined by tracing particular lineages and through strategic associations with select local cultural forms. Rapso must also be discussed in terms of ideology and practice. A socially conscious message and social activism are integral aspects of rapso practice. One without the other renders the rapso practitioner insincere. 


\section{RAPSO IDEOLOGY}

Rapso performance makes a statement about national identity but also speaks to spirituality and respect. By claiming a rapso identity, one is making a commitment to create music of a higher standard or ideal: conscious music, positive messages, and social commentary. Rapso music educates, recounts or rewrites history, challenges authority to right historical wrongs, celebrates life, and validates the emotions and experiences of its community. Brother Resistance's "Ring de Bell" is a song of spirituality and of rebellion. In his words, "Ring de Bell" is "celebrating the power of African religion in the Caribbean and how that religion has, to a great extent, embraced a people and taken them from that period of slavery and bring them to emancipation." He explained,

It's one of those things ... Usually religion is a thing that does really . . lock down people in a way, mentally and spiritually, but in terms of the Baptist and in terms of the Orisha and even Rasta, these are religions that release people, that push people forward and empower them in a certain kind of way. So "Ring de Bell" celebrates that, and the bell is depicted as a symbol of resistance, as a symbol of liberation, because you know at one time when Baptist people ring their bell on a street corner and police come in, they had to run. We used to get lockup for worshiping God! Ah mean, that's how dread the colonial system was. So "Ring de Bell" celebrates all of that in a people, and it calls on the leaders to gather the people who have the same vision, who have the same mission, an' leh we move forward for justice, for culture and for freedom, and of course for de rapso riddum. ${ }^{20}$

Rapso artist Karega Mandela locates his motivation for creating rapso in his desire to uplift the oppressed and dispossessed. ${ }^{21}$ His most celebrated rapso song, "Never Surrender," recounts the achievements of the African people and observes, "We've been oppressed for a very long time, but we never surrender." Acknowledging that the colonial mind-set still exists in Trinidad, his mission is to instill a sense of self-pride in the youth who may feel inferior due to their racial or economic status.

Rastafarianism is also a significant thread that weaves through much of rapso performance practice and ideology. Subscribing to the teachings of Marcus Garvey, the Rastafarian ethos of Black pride and self-determination, anticolonialism, and rejection of "Babylon" is mirrored in rapso artists' politics and activism and is demonstrated by Brother Resistance's performance and call to 
action during Sheldon Blackman's Re-loaded concert. Brother Resistance, himself a Rastafarian, brought Rasta consciousness to the performance through its embodiment in his person and as it was invoked in song via the reference to Marcus Garvey. ${ }^{22}$

Rapso is a performance genre and an ideology, but rapso occupies a dual position within Trinbagonian society. Trinidad, the womb out of which rapso was born, can be a hostile environment for artists whose work deals with serious themes and who assume strong positions in the interest of self-determination. Brother Book elaborates on this reality when discussing the reception of local audiences to rapso music.

Appreciation? Mild, lukewarm. It have to be worked upon. And it's not by accident. I don't expect it to be blooming and flourishing, because people who run the society do not appreciate anything local. The steelband movement is a fight down. The kaiso (calypso) movement is a fight down. Everything we produce, the people here who in authority does fight it down... They don't want nothing positive ... Wine and jam, nani and totie, ${ }^{23}$ penis and vagina ... that is the music they pushing, and if you playing that on the radio constantly, the weak minds must go along that line, so I'm not surprised at the reception. The rapso artists know that they must keep persevering. They have to keep persevering. And when the work is necessary, they must put down the work. ${ }^{24}$

Rapso artists have a history of social activism that continues to this day. Early rapso involvement in trade union activism, labor strikes, and grassroots community development is now augmented by work in arts advocacy, education, prison reform, and regional crisis response efforts, such as assisting with relief efforts in Grenada after the destruction of Hurricane Ivan in 2004. As social conditions in the nation deteriorate, the activist work of the rapso artist becomes more crucial.

Trinidad and Tobago is facing growing concerns from its citizens about violent crime, kidnapping, racial intolerance and discrimination, corruption, poverty, and declining morality. What is perceived by Trinbagonians to be a society in crisis is the daily subject of radio talk shows, television news, and print and online newspaper headlines. An article in the Los Angeles Times brought news of the escalating rate of abductions in Trinidad to an international readership, noting that "an ugly social ill threatens the perpetual party atmosphere: [it is] kidnapping, a crime so epidemic that Trinidad ranks second in the world behind Colombia for its rate of abductions." 25 
Yet despite these negative trends, Trinidad and Tobago is a nation whose distinctiveness lies in its festival aesthetic. Although Carnival is the nation's most widely recognized festival, it is important to note that festivals are used to celebrate and commemorate a host of holidays and significant occasions. ${ }^{26}$ Sheldon Blackman views this festival aesthetic as both a strength and a weakness for the nation of Trinidad and Tobago. Speaking about Trinidadian cultural politics, he contends,

We have a carnival mentality. It is productive yet still destructive ... We live for that time. And even our music industry is structured that way. Three months of Carnival and love it [local music]. And after that, it's foreign music, nine months of the year. And the artist that produces [local] music during that time struggles because you can't hear your music on the radio. During carnival time the music that is being focused upon is jump and wave. ${ }^{27}$ It's beautiful, it's festival music. But we live our life in that festival. We don't even protest seriously. We protest like we're dancing and singing, which is good, which is part of us, but we need to consider our way seriously because there are too many things falling apart around us. ${ }^{28}$

Roger Roberts of 3canal expressed similar sentiments when he noted,

We live in a crucial time, not only in Trinidad, but globally, and if you have special gifts or talents and you have a microphone in your hand, that comes with responsibility. That's why I choose to do it in a positive way or in a way that might uplift or agitate someone to explore deeper or to think rather than just have a good time all the time. That's important too, but we do a lot of that in Trinidad. We celebrate a lot and we party a lot, but we don't think and plan and consider and research and develop and protect ourselves enough. ${ }^{29}$

For the rapso artists, the message of their work is of the greatest significance. Their music and performances provide a platform for their words. Yet the extent to which their words are heard is mediated by the political economy of cultural production in Trinidad and Tobago.

\section{THE POLITICS OF THE MUSIC INDUSTRY}

The local music industry revolves around Carnival, and the popular music of Carnival is soca, which emphasizes pace (a fast beat), movement (jump and 
wave), and release from concerns of the mind to gratification of the body. ${ }^{30}$ For the majority of the festivals and holidays celebrated in Trinidad and Tobago, party music/soca music is the musical expression of choice that reflects festivity as it is internalized in the Trinbagonian psyche.

Rapso music, due to its association with social rebellion and Afro-Trinbagonian political and spiritual identity, finds its way easily into the festivities celebrating Afro-Trinbagonian experiences, such as Emancipation Day or Spiritual Shouter Baptist Liberation Day. However, popular perceptions of the politics of rapso have also served to distance the art form from other festival environments linked to non-African cultural traditions or that are, in effect, mini-carnivals that take place in individual villages or to celebrate landmark events in the nation. Politics of ethnicity and culture in Trinidad serve to circumscribe the use of particular musical genres to particular contexts and occasions. Chutney and chutney soca music is prominently aired on the radio and performed in concerts around the national holiday of Indian Arrival Day, in the same way that rapso, as well as traditional calypso, receives heavy rotation and attention during Emancipation Day and Spiritual Shouter Baptist Liberation Day.

In addition to the ethnic politics of music, local music practitioners struggle to establish their art form in the face of foreign cultural imperialism and the sociopolitics of culture in Trinidad and Tobago, in which local images and music are underrepresented in the media. In an economic system where the livelihood of musicians is dependent on airplay, competitions, and live performance contracts, limitations on the circulation of music have serious consequences for the survival of the artist, of the artistic product, and ultimately of the genre and its ability to shape national culture.

Performing artists whose popularity has secured work for them on the international concert circuit return to Trinidad by the end of October and head into the studio to record their song, or songs, for Carnival. If they have a working relationship with the right studio, their songs may get adequate rotation on the radio and in the fêtes. This rotation in the media cultivates demand for these artists, who then are hired to perform at Carnival fêtes. If their music is very popular and they secure lucrative gigs during the carnival season, they may have enough money to fund an elaborate display of dance, drama, fireworks, or pyrotechnics during their competition for the Calypso Monarch, Soca Monarch, or Chutney Soca Monarch titles. If they are fortunate enough to win one of these major competitions, they are likely to be offered jobs performing at the various carnivals throughout the Caribbean, North America, and En- 
gland, financially sustaining them until the following year's Carnival, when the cycle begins again.

While in Trinidad engaging in fieldwork, I repeatedly heard from insiders in the music industry that the business of soca music in Trinidad and Tobago is dominated by a few individuals, locally referred to as the music mafia, who control the most popular radio conglomerates and who also own recording studios. Through aggressively promoting the music of the artists who record on their label, they shape market demand for music. As a result of strained relationships between the music mafia and rapso artists who refused recording contracts with these studios, the music mafia in Trinidad had blacklisted rapso, to the extent that its deejays were expressly forbidden to play rapso music on their radio stations. ${ }^{31}$

Rapso has also suffered from a decline in its financial support base. Kisskidee and Rituals, the recording companies that were most actively involved with the production and promotion of rapso music, have closed down or been severely downsized due to financial pressures. Given these circumstances, it has become increasingly important to advocate for local content in media programming and for the enforcement of copyright laws that prohibit the pirating of artists' music. Brother Resistance's call for action during Sheldon Blackman's launch of his ReLoaded CD was an impassioned response to the political economy of music production and promotion in Trinidad and Tobago.

\section{AGENCY AND SURVIVAL}

Rapso artists have been fighting for survival for over thirty years and continue to do so today. They create alternative spaces for performances and alternative ways of performing. During the carnival season, Brother Resistance and the Rapso Coordinating Committee produce Rapso Explosion, held at the National Library's outdoor amphitheater. Rapso Explosion is a free concert of practitioners of the oral tradition, from the Pierrot Grenade and Midnight Robber to rapso elders and calypso veterans, and culminates with performances by some of the most dynamic rapso and lyrically oriented soca artists in Trinidad. ${ }^{32}$ The group 3canal has created The 3canal Show, an alternative to the traditional calypso tent; in their show, rapso takes center stage in an avant-garde production of music, dance, theater, and masquerade. Sheldon Blackman hosts the Alternative Dimensions Concert on the Friday after Carnival, where alternative music, including but not limited to, rapso, claims a space in the national landscape.

All year long, spaces are created for rapso to be heard. Brother Resistance 
and Karega Mandela host Word, Sound, Power, an hour-long rapso radio program. One of Trinidad's newest and most successful radio stations, Trini Bashment, ${ }^{33}$ also has made space for the promotion of rapso music through its Monday morning show hosted by Homefront rapso artist OzyMajic. ${ }^{34}$ Through Internet technology, these programs are broadcast not only in Trinidad and Tobago but also throughout the world, via live feeds available online at the Web sites of these radio stations.

Through the activism of rapso artists, April was designated as Rapso History Month. During April, rapso artists travel throughout the nation, working in schools to teach children about their history and oral traditions. Workshops are held for those wishing to begin the journey of self-expression through rapso, culminating in a concert called Breaking New Ground. There are also two other concerts, one honoring women of the oral tradition, where women poets, storytellers, and rapso singers perform, and the other, RapsoFest, showcasing the work of a multitude of rapso artists. Throughout the year, 3 canal hosts parties at their headquarters in Woodbrook or at the Callaloo Company mas camp, in celebration of various holidays (Emancipation Day, Independence Day, Divali, and Eid-ul-Fitr). In so doing, they expand the contexts in which rapso music can be appreciated as a festival music. Rapso artists also create a presence for themselves at other alternative performance spaces, such as the monthly underground open-mic gatherings known as The Speakeasy and Songshine, at steelband concerts throughout the year, and at folk festivals, such as those under the rubric of the Prime Minister's Best Village Trophy Competition.

Rapso is rooted in the local experience, but its messages and references move beyond the shores of Trinidad and Tobago. As demonstrated at Sheldon Blackman's CD launch, Brother Resistance is as comfortable at chanting out the names of Marcus Garvey and Malcolm X, thereby invoking the histories of counterhegemonic struggles in Jamaica, the United States, and Africa, as he is at chanting out praises to Uriah "Buzz" Butler.

Performance, identity, and political ideology are linked in the collective imagination. Rapso is linked to blackness and to revolutionary Afrocentric politics, even though the work of newer-generation rapso artists attracts a broad spectrum of supporters and employs themes that are more universal in their content. Rapso has a historical connection to Black Nationalism, but rapso artists have also established professional relationships and recorded music in collaboration with Trinbagonian musicians of South Asian Indian ancestry, such as Mungal Patasar and Rikki Jai. Further, rapso artists host celebrations of Hindu and Muslim holidays. What emerged as an art form shaped by 1970 an- 
ticolonial politics and Afrocentric sentiments now embraces, in the contemporary moment, an activism that reflects equally important but different struggles.

The contemporary battles to be won by the warriors of the word are to see local images and hear local sounds in the media, to affirm local identities, and to have the world know that music from Trinidad and Tobago is more than soca and calypso. In this postcolonial era, a new imperialism exists in this twin-island nation —one that nods to the colonialism of the past, with its Eurocentric bias and dearth of local icons, and supports the cultural and capitalist-driven imperialism of American hegemony. Simultaneously, another layer of hegemony exists - a locally based, Carnival-driven cycle of music circulation. So the contemporary politics of media is about not only national identity in a transnational global setting but also the reproduction of Trinbagonian culture and, ultimately, of Trinbagonian bodies. Brother Resistance implores the audience to join in the battle to legislate for more local content in the media, so that the "artists and dem could live, and feed dey family, and make more music." The politics of music is also the politics of survival.

Rapso has evolved over the years, and its visibility and popularity have shifted in relation to the premier performance event in the nation, Carnival. While rapso performance has evolved from the same oral traditions that are integral features of Trinidad and Tobago's Carnival, an analysis of the history of rapso and it's positionality vis-à-vis national culture must consider the nuances of "national culture." In this essay, I have discussed the purposeful claiming of "traditional" Carnival characters, such as the Midnight Robber and Pierrot Grenade. In so doing, rapso artists have symbolically moved these characters from the realm of salvage/heritage state-sponsored pageants and performances that support the hegemonic, nationalist agenda back to the downpressed segments of society from which they historically emerged. By consciously tracing their artistic lineage to the chantuelle, rapso artists negate assumptions about dominant flows of cultural production that would locate the roots of rapso in American rap and hip-hop, thereby erasing a significant portion of Trinbagonian cultural history and rendering their performances as nothing more than imitations of foreign forms. By claiming these local historical characters as ancestors of their craft, they imbue their practice with indigenous power and warriorhood.

Through rapso performance events that take place throughout the year, such as the performance at Sheldon Blackman's CD launch at the Pelican Inn with which this essay began, the spirit of rebellion that erupts occasionally and unexpectedly when the forces of oppression become intolerable is invoked in 
pursuit of social justice and a strong sense of identity. Richard Schechner argues, "One must never forget that Trinidad Carnival is played out on the world stage as well as on the island. Far from being an eruption of 'the people,' it is the signature happening of an entire nation, the most prominent mark of its culture." ${ }^{35}$ However, an analysis of rapso's significance as it relates to the construction of Trinbagonian national identity must move beyond what can be ascertained through an analysis of Carnival. One must also seriously consider how local politics of capitalism impede the flow and distribution of artistic production and how new technologies in the transfer of culture, such as the role of the Internet in broadcasting local radio programs throughout the world, contribute to the dissemination of ideas about identity and subjecthood. In a festival nation that is working through the process of defining itself, rapso artists engage in a multiplicity of strategies and temporal frameworks that employ words, music, theater, and performance to advocate for social justice and their place within the boundaries that define the nation. In Trinidad and Tobago, where performance has always been a significant medium for struggles against oppression, the concept of warriorhood is positively equated with passion, determination, and defense of indigenous rights and identity. Warriorhood is a thread that continues to run through the work of rapso artists to the present.

\section{Notes}

1. Rhythm. The use of Trinidadian Creole language by rapso artists is both an act of active resistance against the legacy of colonial Eurocentric hegemony and an unconscious organic expression of an identity shaped by the Trinidadian experience.

2. The nation is comprised of the islands of Trinidad and Tobago. Trinbago and Trinbagonian are contemporary terms used to refer to the nation and the people of the nation, thereby avoiding the Trinidad-centered orientation of the term Trinidadian. When discussing the genre of rapso, I privilege the use of the term Trinidadian, as the overwhelming majority of rapso artists are from Trinidad, and their art and performance reflects the Trinidadian experience. Further, since my analysis of rapso discusses the sound of the language, my use of Trinidadian acknowledges that the sound and structure of Creole speech differs on the two islands.

3. For analyses of the role of Carnival in Trinidad and Tobago, see Cowley, Carnival, Canboulay and Calypso; Dudley, Carnival Music in Trinidad; Green and Scher, Trinidad Carnival: The Cultural Politics of a Transnational Festival; Donald R. Hill, Calypso Calaloo: Early Carnival Musin in Trinidad; Errol Hill, The Trinidad Carnival: Mandate for a National Theatre; Koningsbruggen Trinidad Carnival: A Question of National Identity; Liverpool, Rituals of Power and Rebellion; Riggio, Carnival: Culture in Action-The Trinidad Experience; Riggio, "Trinidad and Tobago Carnival."

4. Jocelyne Guilbault notes in her discussion of music as nationalist discourse, "Seen 
as central in the promotion of national culture, calypso was thought of as bringing the kind of new consciousness needed to eliminate the false sense of self that people experienced under the colonial regime" ("On Redefining the Nation through Party Music," 231).

5. Schieffelin, "Problematizing Performance," 194-207.

6. Jamoo is a category of music established by Ras Shorty I (Garfield Blackman) after he became disillusioned with the way in which soca music had evolved, with its emphasis on electronically synthesized fast rhythms, simplistic lyrics, and the "jam and wine" party environment with which it was indelibly linked. Further, Jamoo was the musical reflection of Ras Shorty I's radical change in lifestyle as he disassociated himself from the womanizing, drinking, and partying typical of many top calypsonians in the 1960 s and 1970s. The term Jamoo is derived from "Jah's Music," and the music is spiritual in lyrical content, while still integrating Shorty I's love for a range of indigenous Trinidadian musical influences, styles, and rhythms. Ras Shorty I and his family formed a band called "The Love Circle," and on this particular night, that band was performing with Sheldon Blackman.

7. The chantuelle is a historic figure in Trinidadian performance. Associated with the gayelle, the stickfighting arena, the chantuelle was a singer who issued forth the praises of a particular stickfighter. The chantuelle is considered an early practitioner of what was to become the calypso form.

8. Heartfelt.

9. Can't.

10. Piracy is the unauthorized and illegal reproducing, distributing, and selling of an artist's music. This informal economy is widespread in Trinidad and Tobago, and legal efforts to control, stem, and prosecute offenders are irregular, at best.

11. Tubal Uriah "Buzz" Butler was an important trade union leader in Trinidad in the 1930 .

12. The Spiritual Baptist religion is an Afro-Christian New World religion that combines Protestant Christianity and African doctrines and ritual observances.

13. Lancelot "Kebu" Layne was a calypsonian credited with being the first artist to perform in a calypso tent using a performance style that was to become known as rapso. The rapso community has conferred upon Lancelot "Kebu" Layne the title "Father of the Rapso Movement."

14. A gayelle is an informal arena in which stickfighting competitions occur.

15. In 1970 Trinidad and Tobago, Black was a descriptive term that was embraced not only by people of African ancestry but also by people of other ethnicities who felt politically aligned with the struggle to radically change social and economic institutions and ideologies that continued to privilege people of European ancestry or those whose skin color and hair texture associated them with whiteness in what was still a very rigidly hierarchical and color-stratified society. Even though Trinidad and Tobago had been an independent nation for almost a decade, having gained its independence from Britain in 1962 , and was governed by what was popularly understood to be a Black political party, the People's National Movement headed by Dr. Eric Williams, darker-skinned people still faced institutionalized racism and discrimination.

16. Brother Book (Hollis Peters), also known as "the Optician" because his work en- 
ables people to see the reality of the social environment in which they live, is an elder in the rapso movement who, along with Brother Resistance, established the National Day of Rapso in Trinidad.

17. The "calypso tent" is the main venue where calypso is performed nightly during the carnival season. Early on, calypso was performed in an outdoor venue covered by a tent, but in the contemporary era, it is performed indoors in public halls and theaters.

18. Downpressed is a Rastafarian version of the word oppressed and emphasizes the extent to which people are kept down by institutions of inequality and discrimination. In my interviews with Brother Resistance, he used the term downpressed to indicate the community for whom his activism is primarily targeted to benefit.

19. Sadre-Orafai, "Hypernationalist Discourse in the Rapso Movement of Trinidad and Tobago," 235.

20. Interview with Brother Resistance, Port of Spain, Trinidad, March 19, 2004.

21. Interview with Karega Mandela, Port of Spain, Trinidad, November 17, 2004.

22. There is a strong link between rapso and Rastafarianism. Several rapso practitioners are Rastafarians, and many performances are preceded by offstage prayers and the invocation of God through ritualized, call and response exchanges (e.g., "Greetings in the name of the most high God, Jah! Rastafari"), which are often offered as rapso artists walk on stage. Not all rapso artists, however, are Rastafarians. In Trinidad, spirituality is often a fluid, multidimensional experience, with people relating to, participating in, and expressing various aspects of multiple religious forms. There is an extensive body of literature that addresses the subjects of religion, syncretism, and creolization in Trinidad, beginning with the work of Melville Herskovits (1947). For some contemporary treatments of this subject, see Henry, Reclaiming African Religions in Trinidad; Houk, Spirits, Blood, and Drums; Khan Callaloo Nation; Korom, Hosay Trinidad; Miller, Modernity.

23. Nani and totie are colloquialisms for the female and male genitalia.

24. Interview with Brother Book (Hollis Peters), Woodbrook, Trinidad, November 9, 2004.

25. Williams, "Kidnappings Send a Chill through Sunny Trinidad," 9.

26. There are thirteen public holidays throughout the year, not including Carnival. To those thirteen days, Carnival, in all its manifestations, adds approximately two months of fêtes, calypso competitions, steelband competitions, masquerade band launchings, traditional masquerade parades and historical re-creations, chutney soca competitions, brass band concerts and festivals, liming at the pan yards, liming at rum shops, and going to concerts. Throughout the year, there are festivals celebrating communities ("We Beat" in St. James, Borough Day in Point Fortin, Tobago Heritage Festival) and festivals celebrating culture and religion ("Best Village," numerous pan festivals, Tobago's Buccoo Goat Race Festival, the Music Festival, RapsoFest, the Hindu Ganga Dhaara River Festival, and the Orisha Osun).

27. "Jump and wave" refers to soca music.

28. Interview with Sheldon Blackman, Mt. Lambert, Trinidad, May 18, 2004.

29. Interview with Roger Roberts, Woodbrook, Trinidad, September 23, 2004.

30. See Balliger, "Popular Music and the Cultural Politics of Globalisation"; Dudley, 
Carnival Music in Trinidad; Guilbault, Governing Sound; and Rohlehr, Scuffling of Islands.

31. Ataklan (Mark Jimenez) expressly addresses music industry politics in his song "I Am Me" from his Atavival CD (Taj Records, 2001).

32. Soca performers that emphasize lyrics and have performed at Rapso Explosion in the past include David Rudder, Maximus Dan, and Bunji Garlin.

33. Trini Bashment, owned by soca performer and businessman Iwer George, is notable for its commitment to programming with 100 percent soca content. Here, the distinctions between soca and calypso and rapso are blurred, and the intent is to promote Trinbagonian popular music. The popularity of this station, coupled with Ozzie Merrique's rapso program, may have a positive impact on the widespread knowledge of and popularity of rapso.

34. Ozzie Merrique's rapso moniker.

35. Schechner, "Carnival (Theory)," 8.

\section{Bibliography}

Balliger, Robin. "Popular Music and the Cultural Politics of Globalisation among the Post-Oil Boom Generation in Trinidad." In Identity, Ethnicity and Culture in the Caribbean, edited by Ralph R. Premdas, 54-79. St. Augustine, Trinidad: The University of the West Indies, 2000.

Cowley, John. Carnival, Canboulay and Calypso: Traditions in the Making. Cambridge: Cambridge University Press, 1996.

Dudley, Shannon. Carnival Music in Trinidad: Experiencing Music, Expressing Culture. New York: Oxford University Press, 2004.

Green, Garth L., and Philip W. Scher, eds. Trinidad Carnival: The Cultural Politics of a Transnational Festival. Bloomington: Indiana University Press, 2007.

Guilbault, Jocelyne. Governing Sound. The Cultural Politics of Trinidad's Carnival Musics. Chicago: University of Chicago Press, 2007.

Guilbault, Jocelyne. "On Redefining the Nation through Party Music." In Carnival: Culture in Action-The Trinidad Experience, edited by Milla C. Riggio, 228-38. New York: Routledge, 2004.

Henry, Frances. Reclaiming African Religions in Trinidad: The Socio-Political Legitimation of the Orisha and Spiritual Baptist Faiths. Kingston, Jamaica: University of the West Indies Press, 2003.

Herskovits, Melville J., and Frances S. Herskovits. Trinidad Village. New York: Knopf, 1947.

Hill, Donald R. Calypso Calaloo: Early Carnival Music in Trinidad. Gainesville: University Press of Florida, 1993.

Hill, Errol. The Trinidad Carnival; Mandate for a National Theatre. Austin: University of Texas Press, 1972.

Houk, James T. Spirits, Blood and Drums: The Orisha Religion in Trinidad. Philadelphia: Temple University Press, 1995.

Khan, Aisha. Callaloo Nation: Metaphors of Race and Religious Identity among South Asians in Trinidad. Durham, NC: Duke University Press, 2004. 
Koningsbruggen, Petrus Hendrikus van. Trinidad Carnival: A Question of National Identity. London: Caribbean, 1997.

Korom, Frank J. Hosay Trinidad: Muharram Performances in an Indo-Caribbean Diaspora. Philadelphia: University of Pennsylvania Press, 2003.

Liverpool, Hollis. Rituals of Power and Rebellion: The Carnival Tradition in Trinidad and Tobago, 1763-1962. Chicago: Research Associates School Times Publications, 2001.

Miller, Daniel. Modernity: An Ethnographic Approach. Dualism and Mass Consumption in Trinidad. Oxford: Berg, 1994.

Ofosu, Natasha. “Unsung Heroes.” Trinidad Guardian, July 16, 2002.

Riggio, Milla C., ed. Carnival: Culture in Action-The Trinidad Experience. New York: Routledge, 2004.

Riggio, Milla C., ed. “Trinidad and Tobago Carnival." Special expanded issue, TDR: The Drama Review 42, no. 3 (1998).

Rohlehr, Gordon. A Scuffling of Islands: Essays on Calypso. San Juan, Trinidad: Lexicon Trinidad, 2004.

Sadre-Orafai, Stephanie. "Hypernationalist Discourse in the Rapso Movement of Trinidad and Tobago." In Globalisation, Diaspora and Caribbean Popular Culture, edited by Christine G. T. Ho and Keith Nurse, 215-41. Kingston, Jamaica: Ian Randle, 2005.

Schechner, Richard. “Carnival (Theory) after Bakhtin.” In Carnival: Culture in ActionThe Trinidad Experience, edited by Milla C. Riggio, 3-11. New York: Routledge, 2004.

Schieffelin, Edward L. "Problematizing Performance." In Ritual, Performance, Media, edited by F. Hughes-Freeland, 194-207. New York: Routledge, 1996.

Williams, Carol J. "Kidnappings Send a Chill through Sunny Trinidad." Los Angeles Times, January 2, 2005, part A, “The World." 


\section{Timba Brava: Maroon Music in Cuba}

\section{UMI VAUGHAN}

Yo traigo la verdad, pa’ tí y pa' tu mamá...

[I bring the truth, for you and your mother too...]

—JOsé LUIS CORTés EL TOSCo (a chorus from his song "Masca la cachimba")

Nowadays all acknowledge the boom of Cuban popular dance music that occurred at the opening of the 1990 and maintained itself until the closing of that decade. ${ }^{1}$ During that period, the musical practices, instrumentation, treatments of traditional themes, and all-new thematic content based on emergent realities-in short, the sound that was born (having, of course, roots in previous epochs)—formed a legitimate and new kind of popular music, called first "Cuban salsa," then "timba." This essay describes timba and argues that it is an important phenomenon where several processes and social debates in Cuba intersect: specifically, I look at economic policy, identity formation, gender roles, and especially race struggle. Because it taps into the spirit of struggle and creativity, I have chosen to call timba "maroon ${ }^{3}$ music," following Puerto Rican historian Angel Quintero Rivera. ${ }^{4}$ What might at first seem an odd connection alludes to continuing systems of racial inequality and to the relationship between marginalized communities and the powers that be. Both timba and maroon life from the colonial period in the Caribbean are based on "outsider identity," unique language, "raiding," and the use of old principles to improvise new styles in emergent social circumstances, which Amiri Baraka calls "the changing same." ${ }^{5}$ Maroons "stress individual style and dramatic self-presentation, openness to new ideas, and value innovation and creativity." ${ }^{\text {Q }}$ Quintero Rivera offers a definition of the Taíno-Caribbean root word simaran. 
Stray or "runaway" arrow ... From there it took on the meaning of "gone," "up in arms," or "mad" used to describe domestic animals that took to the hills, and to men-first indians then later negros-who rose up and sought their freedom far from the dominion of their masters. ${ }^{7}$

Both timba and maroon identity exist in conflict and complicity with the state and mainstream culture. On Cuba's sister island, Puerto Rico, maroons "sought to live on the margins of the state." opposition to the state per se but, rather, to their aversion to subordination under its regime. To safeguard their position, maroons sometimes fought on behalf of the colonial masters or signed treaties that pitted them against fugitive slaves. Timba was born in the face of challenges posed by a radically changing Cuban society in crisis throughout the decade of the 1990s. We will see how timba is an important voice for Afro-Cuban people. Inasmuch as it creates/constitutes a space for particularly Afro-Cuban social/cultural/economic development, timba is "maroon music" in both dialogue and tension with Cuban society. Definitions of the term timba itself give clues to its nature as both a musical genre and a form of social action.

\section{DEFINITIONS OF TIMBA}

Fernando Ortiz suggests that the word timbá is onomatopoeia-like batá, tambó, and so on-replicating the sound of drums. ${ }^{9}$ However, timba was also an old word used in the Spanish army to designate a group of gamblers-deriving from the word timbal, because they often used the kettledrum as a card table. ${ }^{10}$ In the solares of Havana and Matanzas during the nineteenth century, it referred to a meeting of men with drums and rum, synonymous with rumba de solar, one of the roughest (del pueblo [of the people]) manifestations of rumba. ${ }^{11}$ Here we see rumba or timba as a kind of fiesta or social activity that would always include food, drink, song, dance, drums, invited guests from the neighborhood, and so forth. ${ }^{12}$ Roy tells us, "Timba and timbero are expressions that appear frequently in the context of the rumba, exclamations with which one called out to the drummers, to encourage them.." ${ }^{13}$ The word timba implies not only sound but also people (especially marginalized people) and collective action. ${ }^{14}$

Guava paste eaten with bread as an inexpensive snack, called pan con timba, is another common usage in Cuba. Timba also means "belly" (barriga) $)^{15}$ and refers, some say, to the feminine energy of the drum, pregnant with sound and 
power. It is delicious and full of possibilities. The term was first recorded by Los Papines: "I like to hear a bolero, guaracha, or son montuno if it has timba, bonkó." ${ }^{16}$ Timba is Arsenio Rodríguez ${ }^{17}$ and Benny Moré. ${ }^{18}$ There is timba in the swaying stride of Cuban women on any neighborhood sidewalk and even in the desire of foreigners to imitate the way Cubans dance. References to El Benny, Arsenio, and the swaying hips of Cuban women invoke notions of essential Afro-Cuban male and female energy. Issues of race, class, and gender are worked out through timba.

Timba is also a jam session with percussive piano and horns, mixing in jazz, a great deal of son, ${ }^{19}$ and, to round it all off, bass guitar that takes on the voice and musical vocabulary of rumba. ${ }^{20}$ Many Cuban musicians, including Angel Bonne, David Calzado, and César Pedroso, refer to occasions when they played this way during breaks while studying at the Escuela Nacional de Arte (ENA) or Instituto Superior de Arte (ISA). They agree, too, that timba is Cuban dance music in its highest degree of development, made contemporary by incorporating popular music from around the world. ${ }^{21}$ Some identify timba with abstract values like "strength," 22 referring to its sound but also to the way Cubans rely on music as sustenance ("strength") to carry on under difficult circumstances. One of the best timba bands is Manolito y Su Trabuco-trabuco literally refers to a firearm from the times of the independence war of 1895 and figuratively refers to anything forceful or strong. ${ }^{23}$ "La Timba" is also a working-class neighborhood in Havana. The phrase tener timba (to have timba) means "to become enraged." 24 Timba is both a "Cuban attitude toward music and dance" 25 and a social movement or subculture. ${ }^{26}$ Timba is the "convergence of politics and pleasure." ${ }^{27}$

Considering both journalistic and academic writings about timba, one perceives the surprise, frenzy, scandal, rejection, and passion that this movement has aroused and also the acceptance-still contested-that it finally seems to have earned. The discourse on timba categorizes it as brash music, threatening for various reasons, but at once respected for its virtuosity, daring, and success. Like Caliban, timba appropriates language (both spoken and musical) to express its subaltern perspective. ${ }^{28}$ It is a musical performance that has created "a resistant space beyond the realm of politics in which rebelliousness of various sorts or identifications with alternate ideologies may be emphasized." ${ }^{\prime 29}$ It is part of an "unruly musical wave that exploded in Havana in the late 1980s." 30 This uneasy relationship of popular music with the state has existed since colonial times and has only assumed new details after the triumph of the revolution. The tension is caused by the fact that popular music is made by individu- 
als and groups (to some extent) independent of the state and "in some cases in opposition to it." 31

Virtuosi musicians often come from and are still rooted and producing in the marginal barrios of Havana. Few people would dare attack the skill of timba musicians, trained as many of them are in the country's best schools. Nevertheless, some view ambivalently the use of skills developed through study at staterun schools and still perceive the music as vulgar, shamelessly commercial, or simply too black. (Imagine if the architects of early hip-hop were conservatory trained!) As we explore timba and social action in Cuban dance spaces, it is important to recall José Martís claim that to be Cuban is more than to be black, white, or mulato. He insisted that there is no such thing as race-that it was merely a tool used locally to divide the anticolonial effort and globally by men who invented "textbook races" in order to justify expansion and empire. ${ }^{32}$ One aim of his work was to persuade white Cubans to discard their fear of blacks. ${ }^{33}$ Cuba's mulato poet Nicolás Guillén extended Martís ideas about racial unity in Cuba, claiming, "Cuba's soul is mestizo, and it is from the soul, not the skin, that we derive our definite color. Someday it will be called 'Cuban color.' "34 We will see how timba is survival music emanating from Cuba's black communities inspired by Martîs and Guillén's ideal of racial equality and fusion. Timba seeks integration, not separation, through sound.

\section{A LONG TRADITION OF MIXED MUSIC}

Timba is "música mulata," as Puerto Rican sociologist Ángel Quintero Rivera would say—a fusion of multiple elements in which it is difficult to distinguish and separate the ingredients, so well integrated are they in the final product. Musical "alchemists" 35 blend many influences: rumba, son, Afro-Cuban ritual music, jazz, songo, Puerto Rican bomba, North American folk music, reggae, Caribbean and New York salsa, hip-hop, rock, funk, samba, and European classical music. ${ }^{36}$ Cuban pianist Gonzalo Rubalcaba, who is renowned as a jazzman but also participated in important popular dance music projects (very notably with Issac Delgado), says, "Of all the music in the world, Cuban music is among the most capable of assimilating influences of other cultures and sounds without losing its own authenticity, rather enriching it." ${ }^{37}$

The earliest forms of uniquely Cuban music were enriched by African and European sources, ${ }^{38}$ which merged on the island to create totally native Creole forms through an ongoing process of transculturation. ${ }^{39}$ For example, nourished by Yoruba, Bantu, and Spanish roots, Cuban rumba evolved by the mid- 
1800 as a popular music/song/dance complex among poor urban blacks. Rumba functioned as a site where oral histories were constructed, protests raised, and diversion from life's hardships found. Many Cubans rejected rumba because of its African sound-the musical ensemble consisting of clave, three drums or boxes, a lead singer (el gallo), and a chorus-and the overt sexual references of the dance. It was a form created and developed primarily by black Cubans, but because rumba took place in marginalized spaces, some poor whites participated, too.

Though it was played before (perhaps as early as the 180os), son came to Havana from Eastern Cuba in the early twentieth century and emerged by the 1920 s as a genre of international importance. Like earlier forms-for example, danzón $n^{40}$ —it was criticized as too wild, barbaric, and so on. The dance step was described as "lascivious" and dangerous. Robin Moore and Leonardo Acosta remind us that danzón and son were initially repudiated for being black and then later appropriated by the same dominant, white classes that had rejected them. ${ }^{41}$ Danzón and son were eventually used to represent Cubanness and to defend the national culture against the influence of jazz and tango that invaded the island in the 1920s. In their day, when Arcaño y Sus Maravillas mixed danzón and son and when Arsenio Rodríguez developed the orchestra format called conjunto (incorporating the conga drum), both were criticized for their "música negra" and relegated to play in marginal spaces due to the color of their skin. ${ }^{42}$ Even still, son remains the strongest reference point for all Cuban dance music produced since. This love-hate relationship with black music and black people has helped shape timba, which, like any good son of son, has grown and claimed its space despite initial rejection.

\section{TIMBA: A WAY OF MAKING MUSIC}

The instrumentation of timba bands and the particular ways of executing specific instruments in timba reveal increased timbric resources and enriched expressive and technical arsenals for arrangers, allowing greater possibilities for the music in general. It is important to note that there is not a fixed or obligatory format to play timba. In fact, changüi groups or charangas (e.g., the famous Orquesta Aragón) play this style, using the traditional instrumentation for their respective formats. This suggests the lasting effect timba may have on Cuban popular dance music in general. Throughout Havana, small groups entertain at bars and restaurants performing traditional son integrated with clear inflections of timba in their arrangements. For example, at a local bar called 
Siete Mares (the Seven Seas), a quintet with bongo, flute, guitar, violin, and a singer played traditional Cuban music for most of the evening, including songs by Benny Moré, Pablo Milanés, and other Cuban musical legends. They would regularly infuse these numbers with timba-style breakdowns, using the same acoustic instrumentation in a different way.

Following Charles Kiel's analysis of the blues and Deborah Pacini-Hernandez's discussion of bachata, I will here look at timba in terms of four main stylistic elements: structure, timbre and texture, content, and context. ${ }^{43}$

\section{STRUCTURE}

In timba, the traditional organization and interpretation of sections of son compositions-introduction, exposition, and montuno-is altered. Challenging this configuration, arrangers often displace the introduction and begin with a rap or a short tease of the estribillo, or chorus, to be introduced later in the montuno of the song. At times, the presence of estribillos right from the start and throughout compositions, separated by song verses or spoken sections by soloists, make the entire piece sound like one extended montuno. At other times, songs are voiced ensembles up until the montuno begins, at which time a soloist dialogues with the chorus. Sometimes the role of soloist is passed among the main singers of the orchestra right from the song's opening.

There are four sections in timba: la salsa, which is of moderate tempo and performed by a soloist; el montuno, in which the tempo increases, a refrain is introduced, and call-and-response begins; and los pedales, where a hiphop/R\&B-like backbeat is brought in, tempo recedes, and tension is increased with the bass guitar, as the soloist talks rhythmically, introducing the next (more dynamic) refrain. During these first sections, most people dance casino. In the next section, el despelote (the breakdown), a rapped chorus answers the soloist, and both dancers and musicians go into a frenzy, inspired now by the percussive slapping and plucking of the bass guitar (à la Bootsy Collins). During this section, people dance reparto and tembleque. The band then returns to el montuno, los pedales, and so on at will, to add new refrains ${ }^{44}$ and to change the intensity of the performance. The image of a train climbing a hill (la salsa), pausing at its peak (los pedales), and rushing down (el despelote) gives a rough idea of how energy is manipulated over the course of a song. Each of the added chorus refrains can also be called sobremontuno, as in above and beyond the first. Compositions often end with a cooldown, returning to the mellower salsa style used in the opening. 
The changes wrought by timba opened the way for an attitude of free combination of instruments and ways of playing based on patterns from other music styles from the Caribbean, (black) North America, Brazil, and so on, using Cuban son and rumba as points of departure for experimentation.

\section{TIMBRE AND TEXTURE}

Describing timba in general, Orozco emphasizes the predominance of the clave beat from rumba-guaguancó (2-3), which is at times substituted by the clave beat of son (3-2) or other related patterns that appear sometimes at various points within the same composition. Generally, there is a tendency to vary and to fragment phrases, lyrics, and choruses, illustrated by the use of the bass guitar, which no longer marks the stable tumbao pattern associated with Cuban son but instead attacks in a disjointed way that is still graceful in its propulsion of the music and the dancers. The classical tumbao of $s o n^{45}$ has been left behind, replaced now by phrases more related to reggae and funk (by their harmonic progression and their rhythmic attack) but nevertheless very Cuban and danceable, with steps derived from son.

Casanella and González also refer to the extreme fragmentation of the classical tumbao, the perennial counteraccentuations, and the juxtaposition of elements and planes with hard and tense sounds. More specifically, they cite the rhythmic, percussive use of horns, their melodic execution of disjunct phrases-performed often in the sharpest, most strident registers- that gives timba its aggressive sound. As regards actual percussion instruments, the authors underline the segmented polyrhythm of the different timbric layers and a break from the timbric-expressive functions of previous eras, because now groups incorporate trap drums, congas, timbales with bass drum (bombo), and bongo, all improvising freely, as well as guiro, maracas, claves, chequeré, and bell. The simple enumeration of so many different elements gives an idea of the infinite combinations and effects possible rhythmically.

The variations in the patterns of the instruments mentioned cause a perceived acceleration that can be real or only suggested. When we consider the rhythmic role of the horn section leading to climactic moments inside compositions, working in a polyphony of incredible counterpoint and polyrhythm called mambos or champolas, we have a formula to make dancers delirious. The horn section of NG La Banda is affectionately called los metales del terror (metals of terror). So important is the work of the horn section inside the timba format that this naming of the horn section itself has become common—take, for 
example, los metales de la salsa of Issac Delgado, los chamacos (the boys) of El Médico, la zorra y el cuervo (the fox and the raven) of Aramis Galindo, los metales de la élite of Paulo F.G., and so on, responding to exhortations such as “¡Dále mambo!” or “¡Champola pa’ tí!” This tendency in timba is closely related to its roots in jazz.

The vocal style, in turn, is more emphatic as a result of the direct influence of rap, with whole sections spoken in hip-hop style rather than sung in the way of the traditional Cuban sonero. The song style also has characteristics from rumba and black American R\&B, especially in the phrasing and adornments that bend and play in between written notes. Casanella and González cite Mario "Mayito" Rivera, singer of Los Van Van, as an example par excellence of this first tendency (as was Óscar Valdés with Irakere in the previous generation). Singers Michel Maza (who set the vocal style still used by new members of La Charanga Habanera) and Ricardo "Amaray" Macías from Manolito y Su Trabuco are good examples of the second tendency to use vocal riffs patterned after Luther Vandross, Keith Sweat, and other African American R\&B and gospel stars.

\section{CONTENT}

There are several general categories into which timba songs fall textually. Romantic songs, as in many other diasporic popular musics, deal with Westernstyle male-female relationships. Issac Delgado-an excellent salsero whose music exists at the frontier of timba and international salsa with influences from Puerto Rico, New York, and Colombia—sings in "Mi romántica,"

Ella es muy linda por fuera pero más bella por dentro

Donde están los sentimientos más sinceros del amor

Donde se resume la vida en un segundo

Donde se abre una flor, donde ha crecido el mundo...

(Chorus)

La niña más linda, la niña más bonita, la niña que yo quería ¿Quién lo diría?

[She is very pretty, and even more beautiful within

Where the sincerest feelings of love are

Where life is summed up in a second 
Where flowers bloom and the world grows

(Chorus)

The prettiest girl, the most beautiful, the one I always wanted

Who would have thought?]

Songs of betrayal address situations in which a woman deserts her man in favor of a rich foreigner, often depicted as Italian. Playfully, Manolín, El Médico de la Salsa, plans to torment a lover who has scorned him this way by making constant collect phone calls.

Te di mi amor del alma

Te brindé amor sincero

Pero más pudo el interés

Por todo ese dinero.

Y sé que me dejaste

Y sé que me fallaste

Adiós, que te vaya bien

Good bye, my love, te quiero

(Chorus)

Te voy a hacer

Una llamada telefónica

A pagar allá

[I gave you love from my soul

I gave you sincere love

But greed was stronger because of all that money

I know you left me

I know you failed me

Adios, farewell

Goodbye, my love, I love you

(Chorus)

I'm going to call you

by telephone

collect!!!] 
There are boasting songs, which parallel hip-hop, dancehall reggae, and soca in their references to the singer's skill as a musician and a lover. In these two veins, respectively, El Médico toasts,

Somos lo que hay

Lo que se vende como pan caliente

Lo que prefiere y pide la gente

Lo que se agota en el mercado

Lo que se escucha en todos lados

Somos lo máximo

[We are it

What sells like hot bread

What people prefer and request

What sells out in the stores

What's listened to all about

We are the most]

and La Charanga Habanera (1996) boasts,

Yo soy cabillero

Tengo mi medida

Fundo la cabilla que tú necesitas

I'm an ironworker

I've got my size

I do the pipework that you need]

More and more songs contain references to Afro-Cuban religious practices and use pieces of ritual chants or make percussive references to ritual rhythms, or toques. According to Adalberto Álvarez, the early 1990 "coincided with a time when religious spirituality found a space within the institutional life of the

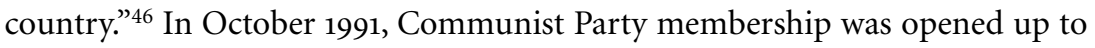
revolutionary Christians and other religious believers. ${ }^{47}$ After this, "Catholics, Protestants, and Jews return to their churches and synagogues openly, and Santería practitioners no longer hide their rituals." ${ }^{38}$ In 1992, the Cuban Consitution was changed to reflect that the state is now "secular" rather than "atheist." ${ }^{\prime \prime}$ 
In jest, but accurately, people say that religion was "depenalized" around the same time as the dollar. As a result, "to sing of the orishas became fashionable in popular music, for good and bad," says Âlvarez. On one hand, "one of our cultural roots was being recovered," but, on the other, "many imitators appeared on the scene with a pseudo folklore that bothers me." 50

El Tosco and his NG La Banda sang often of los santos. In "Santa palabra" (Holy word), they actually incorporate ritual gestures associated with a lucumí (Yoruba) cleansing ceremony called $e b b o$, in which negative energy is removed and then thrown backward over one's shoulders.

Hay muchas personas que esconden los santos

Por el día y por la noche llanto

Para abrir el camino Echu Beleke busca un Eleguá

Pues sin este santo todo va pa tras...

(Chorus)

Despójate, quítate lo malo

Échalo pa tras, limpiate mi hermano

[Many people hide the saints

Crying day and night

In order to open the road, Echu Beleke, find an Elegua

Without that saint nothing goes right

(Chorus)

Strip away, get rid of the bad

Throw it backward, clean yourself, my brother]

Many say that when times get tough, religion becomes more important. Because it developed at the start of the 1990s, as the Soviet bloc collapsed and the so-called special period of rationing and resource management began in Cuba, timba has evolved during a time of intense social change. Timba is one way Cubans have responded musically. Timba is festive and irreverent. The image it portrays is rough and sometimes contrary to authority. For this reason, it has been compared to hip-hop, particularly gangsta rap. ${ }^{51}$ The following, performed by Chispa y Sus Cómplices at La Casa de la Música (April 2003), talks about the continuing slippage of the Cuban peso in relation to the U.S. dollar. 
¡A veinticinco!

¡A veintiséis!

¿Cómo se ha puesto el fula?

¡Duro pero duro de matar!

\section{[At twenty-five!}

Then at twenty-six [pesos to one dollar]!

What's happened to the greenback?

It's playing hard to get!]

Like rappers, timberos defend their music (lyrics and image) as a reflection of reality — what takes place daily in the street. ${ }^{52}$ For example, in a number entitled "No estamos locos" (We're not crazy), La Charanga Habanera, infamous and even banned by the state in 1997 for their "vulgar" lyrics and stage show, sing, “¿Pero qué loco de qué, si lo que canto es lo que es?” (Why am I crazy, if what I sing is what is?).

Controversial texts are common in timba. Casanella and González assert that timba expresses definite sociological messages through its lyrics and its sound. ${ }^{53}$ In terms of lyrics and song structure, the estribillo, by its repetitive and catchy nature, is a favorable vehicle to employ double entendre in function of social criticism; to salute los barrios, personages, and tourist places of Havana; or to share an anecdote or dicharacho (slang term) from everyday life. Singer Issac Delgado, in an interview with Emir García Meralla in the magazine Cuban Salsa, said that "an estribillo makes or breaks a tune, there is no in between," and El Médico adds that "estribillos speak and summarize popular wisdom," that "one is obliged to add a touch of guapería, of street talk, so that you can feel the authenticity of afrocubanness" (emphasis mine).

Casanella, a philologist, discusses the linguistic exchanges between musicians and the public, in which phrases from colloquial slang are taken by musicians and used to popularize compositions (because this is the language of many of their fans), and vice versa. In the latter case, musicians invent a phrase-or take it from a small circle of use, which makes it unknown to most - and popularize and spread it, inserting it in popular speech momentarily or even permanently. Take, for example, tunturuntun, coined by Adalberto Álvarez, which was on everyone's lips during 1999 and 2000 and meant "get outta here," and the saying "No es fácil," coined in the 1980s by Juan Formell and commonly used to this day. 
Song texts are also related on many occasions with choreography, as happened with the steps and accompanying gestures of "Masca la cachimba" by NG La Banda, "El baile del toca toca" by Adalberto Álvarez, or "Te pone la cabeza mala" by Los Van Van. "Arriba de la bola" by El Médico had its own dance and coded meaning. Penned during the special period, many say that "to be on the ball" meant that one had to hustle, to survive by any means necessary. About the dance that accompanied the song, Balbuena writes, "It is characterized by the execution of very sensual, sometimes exotic movements. It is done with arms in the air, bent, hands open, pretending to manipulate a ball or something round [perhaps a globe]. At the same time, the hips, waist, and torso are rotated." ${ }^{54}$ Like the texts themselves, the choreographies are submitted to the creative reinterpretation of the public, and thus the cachimba or la bola semiotically and choreographically take on meanings beyond the intention of their authors.

In a kind of intertextuality, timba compositions make reference to works from diverse musical traditions, both Cuban and foreign. This practice serves to dynamize the improvisations of the soloists and (when the reference is only musical) specific passages of songs, recontextualizing borrowed "licks" that momentarily evoke the experience and meanings of other works. "Qué pasa con ella" from the famous 1997 album Te Pone La Cabeza Mala by Juan Formell y Los Van Van is a good example. When the montuno begins, after the opening argument of the song, most of the improvisations by the lead are bits and pieces of other hits from Los Van Van's then thirty-year career. In this case, they are used to invoke the humor or quality of whichever particular song and underline the group's staying power over such a long time. "When the singer improvises on the main theme of a song, he or she creates new utterances and also rearticulates and culls phrases from other songs of various traditions. The singer opens up a sonorous space of freedom, improvisation, and innovation, clinging simultaneously to tradition and reaffirming collective memory." ${ }^{55}$ Timba shares this approach with international salsa and other popular music styles of the African diaspora.

\section{TIMBA DANCE}

A few styles of dance are generally used with timba. Some dance traditional Cuban son, emphasizing the "ands" of the second and fourth beats with their shoulders and feet. Most folks dance casino-like son, a partner or ballroom dance performed in closed position-now stressing the first and third beats of 
quarter time. Other dances include el reparto (the neighborhood), a kind of vibrating "robot" dance, and el tembleque, a hip-rolling dance similar to those performed by Jamaican "dancehall queens" or Zairean "dancing girls." The complex of dances, gestures, and physical attitudes surrounding timba reaffirms the genre's quality of unpredictability; it revitalizes one of the roots of Cuban popular dance (la rueda/the "wheel dance") and at the same time approaches dance styles from Africa and its diaspora (e.g., reggae and soukous), because they emphasize community dance (in groups and in couples) but deemphasize or eliminate partner dancing in closed position.

The dances that accompany timba seem combinations of the steps and gestures that made up the dances for rhythms of the past-pachanga, collude, pilón, Mozambique, and others. History, fashion, and popular dance repeat themselves. According to Nieves Armas Rigal, coauthor of Bailes populares tradicionales cubanas, the dances called el despelote (the mess/explosion) and $e l$ tembleque (which means "the quake" but also a coconut-flavored pudding), performed today with timba, are no less than the derived product of the aforementioned dances; besides summarizing and extending the Cuban popular dance tradition through movement and gesture, they also emphasize the African roots that nourished it. ${ }^{56}$ This jibes with anthropologist and dancer Pearl Primus's assertion that "the spirit . . responsible for the dynamic [African] dances of yesterday is merely underground" and that "sometimes it will spring forth in a seemingly new form." ${ }^{57}$ About this, César "Pupy" Pedroso says, "Our idiosyncrasy as Cubans is very African. We are descendants of the Africans. All these dances that have come and gone, what we call timba today, $e l$ despelote - all of it is nothing more than African dance." 58

Like other forms of popular dance music, the movements represent "the fundamental connection between the pleasures of the sound and their social realization in the libidinal movement of bodies, styles, and sensual forms." The dance, then, is "a social encounter, which can be [in] a dancehall, a club, or a party, where bodies are permitted to respond to physical rhythms that elsewhere would not be tolerated." It is "the moment when romanticism brushes against reality, and a transitory step out of the everyday can be enjoyed."59 Timba dance implies "a going out of one's self, the creation of alternative space, a state of mind that may function as therapeutic or political liberation." 60 The maroon is present here, too, in dance, as timba dance draws on "the rumba, drumming, and the merengue [that] were prohibited in the colonial [and postcolonial] societies of the Caribbean," including Cuba. ${ }^{61}$ 


\section{CONTEXT}

Timba is a recent development of Afro-Cuban popular dance music. Timba's association with Afro-Cuban culture and with shifts in the Cuban economy and social life plays an important role in perceptions of it as rebellious music. The genre was closely linked to the promotion of tourism in Cuba and was aided by legislation that sought to engage Cuba, at least partly, in the capitalist world economy. Take for example, Paulito F.G.’s song “¿Dónde están los especuladores?" from 1997 (perhaps the height of the timba boom), irresistible dance music with a striking message. In contemporary slang, especulador (literally "speculator") means a "show-off" eager to accumulate, enjoy, and flaunt wealth, a polemical identity in a socialist nation. The word echoes and puns on the older use of speculator, referring to those who, at the start of the Cuban Revolution, were too slow in embracing necessary sacrifices (i.e., surrendering businesses, properties, etc.). Whereas leaders exhort musicians to "think about their society and its values and to write pieces that reflect such [socialist] values," ${ }^{32}$ works that depart from this mission or seem to question it become problematic. In the words of José Quiroga, "this is where the vanguard of expression collides with the vanguard that wants to preserve tradition." ${ }^{63} \mathrm{He}$ continues,

The liberating force is music, but the beat of the music is never allowed to stray from the beat of the state. Music and the state seem to dance around each other, and with each other: music involves musicians and dancers, and these demand venues, and the venues produce a collective expression that may or may not fall into line with what government policies seek to promote. ${ }^{64}$

It seems that some, especially those that criticize timba, imagine that it has nothing to do with authentic Cuban music, either that of yesteryear or other contemporary forms of better taste. We have seen that what is considered proper music is highly contested and shifting terrain. Acosta calls timba "the most important phenomenon of the 1990s and the first [Cuban] music of international popularity and importance since the $1950 \mathrm{s.}^{\prime \prime 5} \mathrm{He}$ corroborates what other writers say, noting the fierce passages from horn sections; the elaborate arrangements; the rhythmic patterns from rumba and santería; the vocals presented in hip-hop style in a context of call-and-response; the disorienting tempo changes; the spontaneous nature of timba music and dance; the use of street language with a festive and irreverent character; and the lyrics considered vulgar, violent, sexist, and "ghetto." But even more interesting, he asserts that 
timba is heir to a long musico-social tradition, in which Afro-Cuban forms debut in the face of very strong opposition that was nourished by racial prejudice and the desire that Cuba (and therefore the music that represents Cuba) not be black.

\section{CONCLUSION}

Many characteristics of NG La Banda and its leader, José Luis Cortés, quoted in the epigraph that starts this essay, are also true of timba. An anecdote about Cortés recounts a television program interview during which he was asked just why he represents Cuban music in such a vulgar, offensive fashion. Instead of responding, he changed the subject, offering to play a piece of classical music for flute supposedly known by all "cultured" people. The host assured him that she was familiar with the work. Cortés proceeded to play a masterpiece of colors and arpeggios and afterward asked if the famous piece was well done. The interviewer said yes, and at that, Cortés declared that what he just played was no famous composition at all but, rather, his own virtuoso improvisation, which embarrassed the host and, surely, many who shared her perspective. The maroon escaped. But not before landing a painful blow. iQué peligro! What danger! As in the words of Cuban scholar Antonio Benítez-Rojo about the marginalized Caribbean identity in general, El Tosco is "a consummate performer with recourse to the most daring improvisations to keep from being trapped." ${ }^{6}$

Timba was born as a maroon music in the face of challenges posed by a radically changing Cuban society in crisis throughout the decade of the 1990s, in which it has been necessary for certain Cubans-blacks and mulatos especially-to reaffirm their identity, presence, and importance in their own terms inside the culture and social structure of Cuba. In terms of maroon aesthetics, timba employs the strategies of "raiding" (borrowing elements from diverse musical sources) and "improvisation" (creating new musical language and style for emergent social circumstances, according to old performance principles). Like maroons of the colonial period, timberos negotiate complex relationships with national/colonial governments and international markets, maneuvering power and opportunity from a marginalized position.

The penetration of marginal Afro-Cuban culture into mainstream Cuban culture in the form of aggressive sounds, marginal themes, vulgar and coded lyrics, and eccentric or "ghetto" self-representations are but affirmations of identity that intend not to destroy Cuban society but, rather, to find a just position within it, as has been the case in the fight of blacks and mulatos in Cuba 
since colonial times. So it is that timba and the reaction of Cubans toward it (and similar movements) are quite significant, complex, and impassioned. Timba will have many repercussions, musically and in the history of Cuba and its beautiful revolution.

\section{Notes}

1. David Calzado, director of La Charanga Habanera, says that the 1990 os represent one of several golden eras of Cuban music and that it waned due to saturation of the public. Paulito F.G. contends that that period represents a special moment because of the fertile production of numerous, restless, young musicians that were impelled to fuse Cuban music with other international styles. Nevertheless, he blames disorganization and inexperience in matters of business on the very part of the young timberos, and he cites lack of promotion and distribution support as reasons that this golden moment came to an end. These criteria and others will be discussed in more depth in this essay. Ned Sublette (Cuba and Its Music, 433) also hails the late 1980s and 1990s as one of several golden ages in Cuban music.

2. Here, timba will be used. It is already the term of preference among musicians and scholars, because it emphasizes the uniqueness of contemporary popular dance music from Cuba.

3. The American Heritage Dictionary of the English Language defines maroon as follows: "a fugitive black slave in the West Indies in the 17th and 18th centuries; the descendant of such a slave; plantation slaves who had run away to live free in uncultivated parts."

4. For Quintero Rivera, salsa is maroon music because its base (in the form of earlier styles) was set by mixed ethnic communities in opposition to colonial authority.

5. Baraka, "The Changing Same."

6. Price and Price, Maroon Arts, 285.

7. Quintero Rivera, Salsa, sabor y control, 265.

8. Ibid., 276.

9. Ortiz, Los tambores batá, 8.

10. Sublette, Cuba and Its Music, 272.

11. García Meralla, "Timba brava."

12. Acosta, Otra visión de la música popular cubana, 40; Sublette, Cuba and Its Music.

13. Roy, Cuban Music, 180.

14. This idea of lower-class blacks being more culturally invested in music and dance is reiterated throughout this essay, both by my informants and by many writers. It may seem stereotypical and implausible, but there is something to it. In Cuba, "popular music has long been dominated by people of color" (Carpentier, La música en Cuba, 38) because music was considered an unstable and even immoral line of work. Throughout the colonial period, much, if not most, of the European military and religious music on the island was performed by blacks and mulatos. By 1831, there were three times more black musicians than whites. This strong identification of blacks with music does not 
also imply lack of ability, interest, or achievement in other areas. See Leymarie, Cuban Fire, 10; Carpentier, La música en Cuba.

15. Balbuena, El casino y la salsa, 93.

16. The song cited, called "Clave para un timbero," here refers to genres of Cuban music. Bonkó is an African-derived word that means "friend." The chorus of the song is "salsa pa 'quí, timba pa llá para los rumberos" (salsa over here, timba over there for all the rumberos). I interviewed Luis Abreu Hernández of Los Papines in 2003.

17. The singer professionally known as Arsenio Rodríguez was born in the small town of Güira de Macurije in Matanzas Province in 1911. The grandson of a slave brought from the Congo, his birth name was Ignacio Arsenio Travieso Scull. For years in the 1940s, dancers would go to La Tropical to dance to his rhythm. See Sublette, Cuba and Its Music, 442; Orovio, Diccionario de la música cubana, 388.

18. García Meralla, "Timba brava."

19. Son is a musical and vocal style of dance music considered one of the basic, most important genres of Cuban music. Its structure has Bantu African as well as Spanish elements mixed in a Cuban way with rhythmic turns, choruses, percussion, and guitar tones. It is danced in closed partner position. The musical ensemble to play it classically includes tres (a guitarlike instrument with three pairs of chords) or guitar, sometimes accompanied by marimbula (a large wooden box with metal keys to pluck; a big thumb piano), guiro, clave, and bongo. It was born in Eastern Cuba at the end of the nineteenth century in towns like Guantánamo, Baracoa, Manzanillo, and Santiago de Cuba. It became the most authentic expression of the humble sectors (blacks and mulattos) of the Cuban social, economic, and political structure. Throughout the twentieth century, composers like Ignacio Piñeiro and Arsenio Rodríguez and performers like trumpeter Felix Chapotín and singer Benny Moré helped to establish son as music of national and international popularity and influence. Son was the main ingredient in New York salsa of the 1970 and continues to be a major touchstone for contemporary musicians in Cuba and elsewhere. See Orovio, Diccionario de la música cubana, 455-60.

20. This took place often in the context of break time for students at ENA or ISA, who were prohibited from playing popular music but did it anyway. César "Pupy" Pedroso, interview with the author, 2003.

21. David Calzado, interview with the author, 2003.

22. Bamboleo, interview with the author, 2003.

23. Manolito Simonet, interview with the author, 2003.

24. Balbuena, El casino y la salsa, 93.

25. Ibid.

26. Perna, Timba.

27. Aparicio, Listening to Salsa, 92.

28. Retamar, Todo Caliban.

29. Moore, Music and Revolution, 8.

30. Sublette, Cuba and Its Music, 272.

31. Ibid.

32. Ferrer, Insurgent Cuba, 4.

33. Brock and Castañeda, Between Race and Empire, 128. 
34. De la Fuente, Nation for All, 182.

35. García Meralla, "Timba brava."

36. Orovio, "Rumba en la salsa, pop, folk y timba."

37. Gonzalo Rubalcaba, interview with the author, 2001.

38. Carpentier, La música en Cuba; Alén, From Afrocuban Music to Salsa.

39. Ortiz, Cuban Counterpoint; Morejón, Fundación de la imágen, 188.

40. Danzón is a ballroom music and dance genre in $2 / 4$ meter, derived as a Cuban interpretation of the French contredanse. Instrumenation included two violins, piano, violin, clarinet or flute, double bass, Cuban pailas (timbales), and a guiro. In the dance, groups of several couples traced figures. The first danzón is said to have been composed in 1879 by Miguel Failde. The form has a clear African-Caribbean lilt, but the African element is not as pronounced as in rumba. See Alén 1999, From Afrocuban Music to Salsa, $121-31$.

41. Moore, Nationalizing Blackness; Acosta, Del Tambor al sintetizador.

42. In the case of Arsenio Rodríguez, this is also due to his way of playing, described as "rowdier and blacker" than other styles in Cuba. For the white dancers of New York (no doubt different from the dancers of Cuba), his rhythm was too difficult to follow: "You had to be Cuban, a good dancer, and on top of that black [to really follow his beat], because it was very slow." The immigration to the United States of musicians Mario Bauzá in the 1930s, Chano Pozo in the 1940s, and Arsenio Rodríguez in the 1950 s was due at least partly to the limitations facing blacks in Cuba. See Roberts, Latin Tinge, 9; D’Rivera, Mi vida saxual, 140.

43. Keil, Urban Blues; Pacini-Hernández, Bachata.

44. La Charanga Forever, personal communication with the author, 1999.

45. The harmonic progression of the classic tumbao for son is I-IV-V-IV-I or, alternately, I-II-VI bimol-V-I (Fabián 1997). Rhythmically, emphasis is placed on the "and" of the second and fourth beats (Moore, Nationalizing Blackness).

46. De la Hoz, "Adalberto Álvarez."

47. Braun, Perspectives on Cuba, 80.

48. Behar, An Island Called Home, 274.

49. Ibid.

50. De la Hoz, "Adalberto Álvarez."

51. Acosta, "La timba y sus antecedents."

52. Ibid.

53. Casanella and González, "Gozando y a lo cubano," 6.

54. Balbuena, El casino y la salsa, 89.

55. Aparicio, Listening to Salsa, 84 .

56. Nieves Armas Rigal, interview with the author, 2003. In 2000, during carnival festivities in Matanzas, a city known as an important center of Afro-Cuban culture, I observed a salsa/timba band perform an oro cantado to the principal Yoruba orishas (mixing Yoruba and Spanish, oro cantado means "tradition sung," an ordered series of songs and chants in acknowledgment and praise of the various Yoruba deities still venerated in Cuba). During this performance, the soloist asked that children or initiates of each orisha join him on stage to dance the steps traditionally associated with them, performed now, however, to the timba beat. The dancers always began with traditional, religious 
Afro-Cuban movements, but as the music intensified, their style changed, evolving quickly into timba, with its own strong African energy. This illustrates well the sacredprofane, ancient-modern continuum spanned by Cuban popular music, this time incarnated as timba.

57. Green, "(Up)Staging the Primitive," 121.

58. César "Pupy" Pedroso, interview with the author, 2003. In the Cuban context, the term African refers to manifestations of black culture "informed by ancient African organizing principles" that crossed the Atlantic from the Old World to the New World. These cultural patterns are sometimes identifiable as derived from specific ethnic groups and sometimes only recognizable as a general "Negro type" (read Afro-Cuban) that is the result of transculturation among original African ethnic groups, Europeans, and Asians on Cuba. In both cases, creation is based largely on a common "understanding, attitude of mind, logic and perception" shared by the various African ethnic groups introduced on the island and used by them to adapt to new circumstances. See Thompson, Flash of the Spirit, xiii; Bastide, African Civilizations in the New World, 8, 10; Ortiz, Cuban Counterpoint; Mbiti, African Religions and Philosophy, 2; Brandon, Santería from Africa to the New World; Herskovits, The Myth of the Negro Past; Ortiz, Los tambores batá.

59. Chambers, Popular Culture, 135.

60. Aparicio, Listening to Salsa, 103.

61. Ibid.

62. Moore, Music and Revolution, 24.

63. Quiroga, Cuban Palimpsests, 147.

64. Ibid.

65. Acosta, "La timba y sus antecedents."

66. Benítez-Rojo, Repeating Island, 24.

\section{Bibliography}

Acosta, Leonardo. Otra visión de la música popular cubana. La Habana: Editorial Letras Cubanas, 2004.

Acosta, Leonardo. Del Tambor al sintetizador. La Habana: Editorial Letras Cubanas, 1989.

Acosta, Leonardo. "La timba y sus antecedentes en la música bailable cubana." Salsa Cubana 2, no. 6 (1998): 9-11.

Alén Rodriquez, Olavo. From Afrocuban Music to Salsa. Havana: Center for the Investigation of Cuban Music, 1999.

Aparicio, Francis. Listening to Salsa: Gender, Latin Popular Music, and Puerto Rican Cultures. London: Wesleyan University Press, 1998.

Armenteros Mejuto, Zoe. “Una descarga con Juan Carlos Alfonso." Ritmo Cubano, revista de la casa discográfica de la EGREM (1997).

Balbuena, Bárbara. El casino y la salsa en Cuba. La Habana: Editorial Letras Cubanas, 2003.

Baraka, Amiri [LeRoi Jones]. “The Changing Same (R\&B and New Black Music)," In The LeRoi Jones/Amiri Baraka Reader, edited by William J. Harris, 186-209. New York: Basic Books, 1999. 
Bastide, Roger. African Civilizations in the New World. New York: Harper and Row, 1971. Behar, Ruth. An Island Called Home: Returning to Jewish Cuba. Piscataway, NJ: Rutgers University Press, 2007.

Benítez-Rojo, Antonio. The Repeating Island: The Caribbean and the Postmodern Perspective. Durham, NC: Duke University Press, 1996.

Brandon, George. Santería from Africa to the New World: The Dead Sell Memories. Bloomington: Indiana University Press, 1997.

Braun, Theodore A. Perspectives on Cuba and Its People. New York: Friendship Press, 1999.

Carpentier, Alejo. La música en Cuba. Mexico City: Fondo de Cultura Económica, 1946.

Casanella, Liliana. “Textos para bailar: ¿Una polémica actual?” Salsa Cubana 2, no. 7 (1998): 12-15.

Casanella, Liliana, and Neris González. "Gozando y a lo cubano con la Charanga Habanera." Salsa Cubana 5, no. 16 (2001): 14-17.

Chambers, Iain. Popular Culture: The Metropolitan Experience. London: Methuen, 1986.

Daniel, Yvonne. Rumba: Dance and Social Change in Contemporary Cuba. Bloomington: Indiana University Press, 1995.

de la Fuente, Alejandro. A Nation for All: Race Inequality and Politics in Twentieth Century Cuba. Chapel Hill: University of North Carolina Press, 2001.

de la Hoz, Pedro. 1997. “Adalberto Álvarez: En el alma de los bailadores." In Tropicana Internacional, no. 3 (1997): 2-6.

D’Rivera, Paquito. Mi vida saxual. San Juan, Puerto Rico: Editorial Plaza Mayor,1998.

Fernández Robaina, Tomás. El Negro en Cuba 1902-1958: Apuntes para la historia de la luch a contra la discriminación racial. La Habana: Editorial de Ciencias Sociales, 1994.

Ferrer, Ada. Insurgent Cuba: Race, Nation, and Revolution, 1868-1898. Chapel Hill: University of North Carolina Press, 1999.

García Meralla, Emir. “Timba brava.” Tropicana Internacional 4 (1997): 47-48.

Green, Richard. “(Up)Staging the Primitive: Pearl Primus and 'The Negro Problem' in American Dance." In Dancing Many Drums, edited by Thomas F. De Frantz, 105-42. Madison: University of Wisconsin Press, 2002.

Herskovits, Melville J. The Myth of the Negro Past. 1941. Reprint, Boston: Beacon Press, 1990.

Keil, Charles. Urban Blues. Chicago: University of Chicago Press, 1966.

Leymarie, Isabelle. Cuban Fire: The Story of Salsa and Latin Jazz. New York: Continuum, 2002.

Mbiti, John S. African Religions and Philosophy. London: Heinemann Press, 1969.

Moore, Robin. Music and Revolution: Cultural Change in Socialist Cuba. Berkeley: University of California Press, 2006.

Moore, Robin. Nationalizing Blackness: Afrocubanismo and Artistic Revolution in $\mathrm{Ha}$ vana, 1920-1940. Pittsburgh: University of Pittsburgh Press, 1997.

Morejón, Nancy. Fundación de la imágen. Havana, Cuba: Editorial Letras Cubanas, 1988.

Orovio, Helio. Diccionario de la música cubana. La Habana, Cuba: Editorial Letras Cubanas, 1992.

Orovio, Helio. “Rumba en la salsa, pop, folk y timba.” Salsa Cubana 2, no. 5 (1998): 14-17. 
Orozco, Danilo. [Unpublished] Nexos globales desde la música cubana con rejuegos de son y no son. La Habana, Cuba: Ojalá.

Ortiz, Fernando. Cuban Counterpoint: Tobacco and Sugar. 1940. Durham, NC: Duke University Press, 1995.

Ortiz, Fernando. Los tambores batá de los yorubas. 1951. Havana: Publicigraf, 1994.

Pacini-Hernández, Deborah. Bachata: A Social History of a Dominican Popular Music. Philadelphia: Temple University Press, 1995.

Perna, Vincenzo. Timba: The Sound of the Cuban Crisis. Burlington, VT: Ashgate, 2005.

Price, Sally, and Richard Price. Maroon Arts: Cultural Vitality in the African Diaspora. Boston: Beacon Press, 1999.

Quintero Rivera, Ángel. Salsa, sabor y control: Sociología de la música "tropical." Havana, Cuba: Fondo Editorial Casa de las Américas, 1998.

Quiroga, José. Cuban Palimpsests. Minneapolis: University of Minnesota Press, 2005.

Retamar, Roberto Fernández. Todo Caliban. La Habana, Cuba: Editorial Letras Cubanas, 2000.

Robaina, Tomás Fernández. "Marcus Garvey in Cuba: Urrutia, Cubans, and Black Nationalism." In Between Race and Empire: African-Americans and Cubans before the Cuban Revolution, edited by Lisa Brock and Digna Castañeda Fuertes, 120-28. Philadelphia: Temple University Press, 1998.

Roberts, John Storm. The Latin Tinge. 2nd ed. New York: Oxford University Press, 1999

Roy, Maya. Cuban Music: From Son and Rumba to the Buena Vista Social Club and Timba Cubana. Princeton: Markus Weiner, 2002.

Sublette, Ned. Cuba and Its Music: From the First Drums to the Mambo. Chicago: Chicago Review Press, 2004.

Tabares, Sahily. "Paulito F.G.: El bueno soy yo." Salsa Cubana 1, no. 2 (1997): 26-29.

Thompson, Robert Farris. Flash of the Spirit: African and Afro-American Art and Philosophy. New York: Vintage Books, 1984. 


\title{
Salsa Memory: Revisiting Grupo Folklórico y Experimental Nuevayorquino
}

\author{
JUAN FLORES AND RENÉ LÓPEZ
}

Eddie Palmieri makes it a point these days to remind us that La Perfecta II is not meant to be a "revival band." Rather than "reviving," he thinks of this presentday remake of his groundbreaking band from the early 1960s, Conjunto La Perfecta, as "revisiting" an earlier concept and context. Instead of just a rerun of an older phenomenon, "revisiting" is a more creative, with-the-times way of recreating, of reenvisioning musical breakthroughs and discoveries of an earlier era still very much alive in the minds and hearts of many listeners and dancers today. In a way, it's post-salsa revisiting pre-salsa and perhaps arriving at the core of this thing called "salsa" in the process. The irony is that, whatever its intent, the recordings and concerts of La Perfecta II, which remain remarkably faithful to the original sound, have been generating something of a revival of salsa in its irresistible infancy, ever since Eddie birthed the new group some forty years later.

Even more recently, there is another important and related salsa revival/revisitation afoot. The current return of Grupo Folklórico y Experimental Nuevayorquino is likewise not intended as a mere throwback to the heyday of its predecessor in the mid-1970s, even though most of the original musicians are still in place and though their repertoire mainly consists of the original tunes from their two collectible LPs, Concepts in Unity (1975) and Lo Dice Todo (1976). But in their historic concerts in Berlin in September 2007 and at the Smithsonian Folklife Festival in June 2008, the new, regrouped Grupo is moving their bold musical concept in directions unexplored and in accord with cultural and musical developments of the intervening years. Though the dialectic of "folk- 
lore" and "experimentation," tradition and innovation, remains the guiding premise, what constitutes both "folklore" and "experiment" has of course changed with the times and with a changed Nueva York.

In both cases, revisiting Conjunto La Perfecta and the original Grupo Folklórico amounts to an exercise in musical and cultural memory. La Perfecta II seeks to transport us back to the early 196os in Latin music, when a new generation of young, second-generation New York Puerto Ricans began to come out with their own style, building on, but distinct from, the prevalent sound of the previous, mambo era of the 1940 and 1950 . They revered the giants of that formative period-Machito, Tito Rodríguez, and the first New York-born mambo king, Tito Puente-but they had to strike out in new directions of their own making. The Cuban pachanga was the first new rhythm that the young Turks picked up on, and Charlie Palmieri, Ray Barretto, Johnny Pacheco, and other upcoming bandleaders and instrumentalists took up this Nueva York-inflected variant of the traditional Cuban charanga sound, with its characteristic smallband format featuring flute and violin. Eddie famously carried the innovation even further by-following the lead of legendary plenero Mon Rivera-highlighting a frontline of trombones. This was what his brother Charlie jokingly called "trombanga," and with a slew of unmistakable recordings featuring the symbiotic collaboration of Eddie and trombonist Barry Rogers, Conjunto La Perfecta contributed more than any other group to creating a new sound of the times. Here was the initiation of the musical revolution that nearly a decade later, around 1970, came to be called "salsa."

The reunion of Grupo harkens back to a different time in the salsa story, toward the waning, rather than the dawning, of that musical heyday. By 1974, when Andy and Jerry González formed the Conjunto Anabacoa (the first name of Grupo), and 1975, when the original ensemble recorded Concepts in Unity, New York Latin music going by the name of "salsa" had already reached the peak of its commercial popularity under the aegis of Fania Records, the label that made salsa into a known quantity. Indeed, salsa itself was by then a "label," as it were, in the existing market of musical commodities. Less clearly perhaps, "salsa" was also an identifiable stylistic option among the expanding repertoire of a budding "world music." What had begun a decade or so earlier as the voice and feel of a generation and a community, as exemplified by Conjunto La Perfecta, was by the mid-1970s already degenerating into a formulaic commodity field characterized by a predictable and overproduced sound.

The Fania All-Stars and the label's packaged stable of in-house musicians came to stand for that standardization in the eyes and ears of many of the most 
creative musicians of the time, including some who had recorded with Fania. They felt that the making and marketing of "salsa" involved a betrayal of treasured musical roots and, at the same time, a blunting of any experimental and creative edge to their expressive struggle. Andy González explained, "Fania used the Motown formula of recording music, which was to use the same group of musicians, the same rhythm sections for almost every recording. The same arrangers, the same producers, and the same-sounding kind of product." ${ }^{1}$ In The Book of Salsa, Venezuela historian César Miguel Rondón speaks of the Fania-produced salsa of this period as "supermarket music" and describes the label's 1974 crossover album Latin, Soul, Rock as a "new musical trend" introduced by the company "to represent the convergence of styles that dominated the pop music market at the time." "The new product, 'Latin Music,'” he says, "was a sort of rock with congas."

Grupo Folklórico was the epitome of this sentiment and an epicenter of resistance to the hegemony of the industry in the doings of musical practice and creativity. ${ }^{3}$ Drawing together a dream team of practitioners from a range of Afro-Cuban and Puerto Rican genres, arguably the best at their respective instruments, the formation of Grupo was obviously not at odds with the "allstar" idea, which was widespread on the scene in those years and typified by Fania and also the Alegre All-Stars, the Tico All-Stars, and such stellar groupings for many other labels. What was different about Grupo and what set it in polar contrast with the Fania enterprise and the salsa-as-Fania narrative were its musical concept, practice, and product. Here was salsa that was at the same time anti-salsa, New York Latin music designed to run directly counter to "salsa" as invented, tailored, and packaged by the market, most visibly represented by Fania. Grupo's guiding aesthetic of folkloric tradition and contemporary experimentation rooted in a specific social place-Nueva York-aimed to offer a clear, attractive, and real alternative to the deracinated, decontextualized, and creatively stifling results of the commercializing process.

Grupo's two LPs, which have enjoyed an avid international following of salsa connoisseurs for over three decades, exhibit that aesthetic in action and the wide range of styles and instrumental resources that intermingle and are brought into dynamic unison in their unique repertoire. To start with the personnel and instruments, the original group's forte and binding element was of course the rhythm section, anchored in Manny Oquendo's solid timbales, Andy González's versatile bass, Oscar Hernández's percussive piano, and an array of seasoned drummers including Milton Cardona, Frankie Rodríguez, and Gene Golden on batás and Jerry González on tumbadora and quinto. Other instru- 
mental mainstays included the masters Chocolate Armenteros on trumpet, Nelson González on tres, Jose Rodrigues and Reinaldo Jorge on trombone, and flutist and tenor saxophonist Gonzalo Fernández. The main vocalists were the seasoned Cuban Virgilio Martí; Willie García, already a veteran Cuban salsa singer at the age of thirty-six; and street musician par excellence Genaro "Henny" Alvarez, a Puerto Rican drummer, composer, and singer. This core of accomplished and highly regarded exponents of Cuban and Afro-Caribbean music, plus an assortment of special guest appearances and cameos by the likes of master batá drummer and singer Julito Collazo, violinist Alfredo de la Fé, legendary vocalist and composer Marcelino Guerra, and Carlos "Caito" Díaz, who had been a vocalist with La Sonora Matancera since its founding in 1924, assured a seemingly boundless resource of musical possibilities and experiments in multiple musical languages. Though they were all stars or were to become stars in subsequent years, the idea was not so much a lineup of celebrities as a collective of players in synch, held together by their love for the music, respect for each other, and connection to community and by the guiding premise as conceived primarily by the González brothers (Andy and Jerry) and Manny Oquendo and by the steady-handed and expert sensibility of producer/mastermind René López. López, a New York Puerto Rican born and raised in the Bronx, is a ubiquitous presence in the story of New York Latin music since the 1960 s and an undisputed guru of Afro-Cuban music this side of Havana. Along with coproducer Andy Kaufmann, it is he who is mainly responsible for renaming the group "Folklórico y Experimental Nuevayorquino," boldly articulating its central concept, and for reuniting and recasting the group thirty years after its short-lived apogee in the mid-1970s.

As for the music itself, the taproot and trunk of the stylistic tree is of course Afro-Cuban music in its wealth of variants, especially the rumba guaguancóson montuno continuum. But the albums contain many other genres, most of them brought into lively interaction with that basic stylistic modality: guaracha, bolero, charanga, Puerto Rican bomba and plena, Brazilian samba and bossa nova, calypso, Mozambique, and of course various jazz idioms are all present in this constantly shifting and surprising pastiche. There is not a piece in either of the collections that is not in the tradition of one or the other "folkloric" form, yet there is also none in which this primary style is left intact, as it were, and not interrupted and mixed with other stylistic languages.

The first selection on Concepts in Unity, for example, "Cuba Linda," probably the best-known and most beloved song in their repertoire, is a nostalgic hymn to the lost homeland, a beautiful, alluring guaguancó sung incomparably 
by Virgilio Martí. Though recognized as a guaguancó, the piano, tres, flute, and timbal parts tend to veer off from that genre's usual instrumentation, and Chocolate's ever-present trumpet gives it a flavor of classical son in the manner of the septetos of the 1920s and 1930s; indeed, the lyrics even include some familiar lines from Ignacio Piñero, the leader of Septeto Nacional and generally considered the father of the traditional recorded son. In that vein, the following track on the album, "Choco's Guajira," is an unmistakable example of the son guajira, featuring the lush trumpet of Chocolate in his inimitable style, but here again other stylistic qualities also come through. A signature piece, "Anabacoa," for which the group is perhaps best known and which even mentions "el Conjunto Anabacoa," is a powerful guaguancó recorded by Arsenio Rodríguez, which includes an extended piano solo that shows strong jazz influences. Two songs from Puerto Rican folklore, "Adelaida" and "Luz Delia," leave no doubt that they are a plena and a mazurka, respectively; but in the Grupo context, their traditional features are constantly interrupted and toyed with in multiple ways, be it the unexpected trombone and cowbell in "Adelaida" or the complex string and hand drum parts in the mazurka. The same kind of deliberate and creative interference is evident in the two religious invocations to the orishas, "Canto Asoyin" and "Canto Ebioso," both executed with appropriate reverence to the original musical forms, but both complicated by fascinating interventions, most notably Andy González's bass part in "Canto Ebioso."

The most characteristically "Grupo-style" numbers on both albums are the street rumbas (rumbas callejeras), generally composed and/or sung by Henny Alvarez, a veteran of the rumba scene in Central Park and composer of several of Grupo's songs (along with, interestingly, the lyrics for Larry Harlow's salsa opera, Hommy). On Concepts in Unity, those tunes are "Carmen la Ronca" and "A Papá y a Mamá." The most prominent among these tunes on Lo Dice Todo is the leadoff piece, "Cinco en Uno Callejero," called such because of the interplay of five different rhythms centering on Puerto Rican bomba. "Corta el Bonche," "La Mama," "Aguémimo," and "Iya Modupué" all share that quality of a very freewheeling and open-ended "experimentation" with the rumba guaguancó and guaracha.

The unquestioned mastery of the traditional forms that is demonstrated by the musicians allows them to move in and out of any given folkloric expressive field and bring to bear an assortment of other idioms in fully complementary ways. The social implication is that the densely multicultural demography and soundscape of the home location, Nueva York, make for the ready presence of all of these rhythms in their daily lives, and it is precisely the mixing and weav- 
ing that typify the musical locale in which they all find themselves. Though their music is fundamentally Cuban in its national origin, all but a few members of Grupo are New York-born Puerto Ricans, whose diasporic urban lives allow them familiarity with and command of a huge range of styles and rhythms. Great Cuban masters like Chocolate, Julito Collazo, and Virgilio Martí do help ground the performances in lifelong Afro-Cuban musical experience, but none of them would question the chops of any of the other players-like Nelson González on tres, Frankie Rodríguez, or a whole rhythm section on their respective instruments, as idiosyncratically Cuban as those instruments may be.

The key term for this kind of music making is descarga, the jam session. It is informal, improvisational, and fun, as a matter of principle. Originally, descargas often happened in after-hours clubs and private parties, or in a nonperformative mode, and without any scored arrangements whatsoever or even much by way of a preconceived plan. There is such confidence and respect among the musicians that structures and sequences take shape during the course of the presentation, and interactions, though challenging and emulative, are free of the interpersonal jealousies and competitiveness that so often poison collective endeavors. Of course, the idea of the Fania All-Stars was also based on the descarga format and on sharing the stage among peers, most obvious in the typical alternation of solo stretches that much Latin music shares with and perhaps borrowed from jazz performance practice. The tracks on the Fania AllStar recordings are also long, many ranging close to ten minutes in duration, as are those of Grupo, so that in neither case was there much regard for the usual limit on the length of singles recordings.

The difference, in my view, has to do with the relatively greater tightness of the weave among the instrumental parts and with a sense of structural coherence that emerges from the Grupo numbers despite all their informality and extemporaneity. The relative openness of the form and seeming randomness of the delivery in a piece like, for instance, "Iya Modupé," the closing number on Concepts of Unity and, to my taste, their crowning achievement among all the many gems, does not preclude the distinct and pleasing feel of a coherent sequence of mood and pacing. The development is evident in the vocal line of that song, which moves from a self-assurance in the early parts, to an unsettling effect toward the middle section due to the periodic intervention of restless trombone and bass parts, and then to a forceful resolution or restoration of confidence at the end with the lengthy flute solo, the interaction of coro and trombone, and then Chocolate's lyrical trumpet taking it out for the final 
minute. This, for me, exemplifies descarga at the pinnacle of its potential-improvisational yet deliberate, open but structured, experimental and folkloric.

Rather than necessarily the same songs or even the same musicians, it is this realization of the descarga principle or technique that René López and the group seek to "revisit" in their new incarnation in our times. It is not quite clear why the members of Grupo decided to go their separate ways in 1977; the band was in fact gaining increasing acclaim, and their records were still selling well amid many invitations to perform. ${ }^{4}$ But in the intervening years, all have gone on to successful careers in many bands, some of them under their own leadership; those who were not already luminaries have become so-that is, those who did not pass away (as did some core members like Virgilio Martí, Jose Rodrigues, Frankie Rodríguez, Gonzalo Fernándes, and Henny Alvarez) or cease to be active in music (as did Willie García).

The most widely acknowledged sequel to and outgrowth of the Grupo of the 1970 s was no doubt Conjunto Libre, mainly because of the central formative role, once again, of the González brothers, Manny Oquendo, Oscar Hernández, and Nelson González. Renamed Libre and then Manny Oquendo's Libre (because of the anchoring role of the seasoned and tireless timbalero), the band added Barry Rogers to join Jose Rodrigues on trombone for the first time since their collaborations in Conjunto La Perfecta. Relative newcomers (at the time) who were added were soon-to-be-master Nuyoricans Papo Vázquez on trombone and David Valentín on flute. Libre continued the energetic initiative of Grupo in resisting the commercialization of salsa, but by comparison, they incorporated less of the "folkloric" and more of the "experimental" (including more Latin jazz) into their sound, which was more in line with recognizable salsa at its best. Though lacking the name value and market backing of the Ray Barretto, Willie Colón, or Eddie Palmieri recordings, Libre has its place of honor in the annals of salsa. Along with the Latin jazz breakthroughs of the Fort Apache Band under the primary tutelage of Jerry González, the role of these post- and anti-Fania projects in the history of New York's Latin music has been consistently bold and pioneering, contributing to a strong counternarrative of that history.

Now, a full generation after the heyday of salsa, Grupo is back. The taste for old-school salsa from the 1970s, before it was eclipsed by merengue and hiphop and salsa romántica, is still very much alive and has been amplified by a huge and growing international audience of listeners and dancers. For many, what passes for modern-day salsa lacks both the folklore and the experimentation of the good old stuff, and for a surprising number, that has meant not so much 
Fania but Grupo. The musicians and René López could not help but get wind of that continued and growing interest, and the idea for a reunion of Grupo took hold. López's project called for a new CD recording, to be promoted and accompanied by a documentary video about the group, including profiles of some of its individual members. As mentioned, all but a few of the original performers are still playing actively, and all responded enthusiastically when first approached about the idea. The only question was, what would be the right occasion and venue for the reunion?

Chance has it that in those very days during 2006, the House of World Cultures (Haus der Kulturen der Welt) in Berlin, Germany, was planning a major showcase of New York City cultures for the fall of the following year. When told of the plans to reunite Grupo, they made a well-advised beeline for René López, and plans were set with no further ado: Grupo would do a single live concert in the halls of the Haus der Kulturen in September 2007, all for video and audio recording. López figured this would be an excellent trial run, to then be followed by other cameo concerts, one at the Smithsonian's Folklife Festival, the other in the "at-home" setting of Hostos Community College in the South Bronx, in July and November 2008, respectively. (It is the third of these reunion appearances, the one at Hostos, which is being earmarked for a possible live CD recording.) Meanwhile, a film crew has been shooting and interviewing at all rehearsals and appearances, as well as at a formal conversation with René López about the concept and history of Grupo.

The concert in Berlin came after two rehearsals in New York and one on location. The core standbys-Andy and Gerry, Manny, Nelson, Oscar, Gene Golden-were joined by new members, some of them of huge musical presence: Oscar "Puntilla" Ríos who replaces Julito Collazo on the santería end of the repertoire and Virgilio Martí at the deeply traditional percussion and vocal parts; Jorge Maldonado, longtime singer for La Sonora Matancera and now lead vocalist in place of Henny Alvarez; Abraham Rodríguez, the versatile young Bronx Puerto Rican percussionist and backup vocalist strongly schooled by Puntilla, in place of Willie García; Eddie Zervigón, musical director and flutist from Orquesta Broadway; Guido González filling in for Chocolate, who was not available for the trip; and Eddie Venegas, a very young, classically trained Venezuelan multi-instrumentalist who held up well on both violin and trombone. Under the musical direction of Andy González, the group started off a bit falteringly but soon started clicking. They reached impressive intensity toward the end, on "Anabacoa" and "Se Me Olvidó que Te Olvidé," when the international crowd delighted in recognizing and even dancing to the beloved 
and unique Grupo sound once again and in live performance. For the most part, the group stayed with the original songs from the records, which they used as a gauge and standard. At this point, they were at what we might call the "revival" stage of the renewal, the main goal being to do justice to the songs as they sound on the recordings.

The concert on the mall in DC, in the huge tent facing the Smithsonian castle, was an even more energetic occasion than that at the congenial Haus der Kulturen and had an even more synergetic audience; it also carried more personal resonance for the original members of the group, for it was in that same context and venue, the Smithsonian's annual Folklife Festival on the mall, that they had played in 1975. Again the rehearsals were a bit edgy, and the opening numbers were sometimes shaky. But once they got into a groove, there was the old irresistible and inimitable Grupo doing their thing, with some interesting and inevitable variations reflecting the renovated personnel and their diverse strengths. Though they again stayed for the most part with the known repertoire, there was more daring in veering off from the original versions as recorded. Some of the intensity of the moment was that of the new Grupo, with presences like those of Puntilla and Eddie Zervigón having their indelible mark and with newcomers like Venegas and Abie Rodriguez bringing new accents and angles to the familiar songs.

On this occasion, though, they decided to add one new entry to the repertoire, a Grupo version of Arsenio Rodriguez's canonical son montuno "La Gente del Bronx," with its resounding chorus "el elemento del Bronx!" The idea, of course, was not only to pay further tribute to Arsenio, the single most important overall influence on Grupo and its members, the towering figure who showed that "modernizing" the son meant not a separation from but a deepening of the musical tie to African and guaguancó roots. The newly minted selection was also meant to reemphasize the group's Nueva York location and even to specify the centrality of that borough of the city where most of the musicians live and grew up and where Arsenio spent some of the most productive years of his momentous career. Here was the occasion for Grupo to celebrate the master once again and to execute in the spirit of Arsenio, if not à la lettre. Beyond the varied adjustments and reworking of the song as they knew it from the Arsenio recordings, they decided to make one change in the lyrics, so as to bring the original up to date and in line with the times: when the coro in Arsenio's tune sings "igual bailan mambo que el danzón," the singers in the new group replace the danzón reference with the dance sound of young people in the Bronx today: "igual balian mambo que reggaetón.” It is in that irreverent, experimen- 
tal spirit in their relation to the folkloric giant Arsenio Rodríguez that the new incarnation of Grupo Folklórico is revisiting itself-and asks to be revisitedas a cultural phenomenon.

We are writing in July 2008, and preparations are by now underway for the concert on November 1 at Hostos Community College. It promises to continue the revisiting process and to take the re-creation of Grupo to an even higher level. First off, they will be rejoined by Jerry González, who could not take part in the DC event. There are also plans for cameo appearances by important complementary musicians. Here, Grupo will be playing on their home turf-in the Bronx, Nueva York, of their folklore and their experimentation-so the interaction and energy should be even more symbiotic than in the earlier reunion concerts. What exactly to expect is hard to tell, of course, what with the very special assortment of musicians, all involved in wide-ranging projects of their own and sure to bring some of that to the session.

But the one planned feature of the program that holds my deepest interest and curiosity is the inclusion of Eddie Palmieri making an appearance on piano to play his signature hit of all time, a Grupo version of "Muñeca." What will the masters of Grupo do with this contagious song from the La Perfecta album Lo Que Traigo Es Sabroso from 1964. How will they and Eddie "revisit" that cherished number that all of them have played many times, which, perhaps more than any other song, can be identified with salsa as a musical modality even though it was written and popular years before the music was called by that name.

Here, with the anticipated Grupo/Eddie version of "Muñeca," musical memory comes full circle, since most of the original core members of Grupo Folklórico - the Gonzalez brothers, Nelson, Manny, Oscar Hernández, Jose Rodrigues-either cut their teeth playing with Eddie or are a result of the revolution he wreaked on New York Latin music in the early 1960s. René López even refers to the original Grupo as an "Eddie Palmieri Alumni Band."5 By way of explanation, López states that the whole Grupo concept and experience grew out of the musical era ushered in by Palmieri's "trombanga," including the dialectic of folklore and experimentation that was their hallmark.

Revisiting La Perfecta and revisiting Grupo Folklórico are thus part of the same process, which is in a larger sense about revisiting salsa. These two efforts are about re-creating, respectively, the seeds and the harvest of salsa, thus critically flanking its boom period from both historical directions. Call it "revisiting" or even "revival," both reunions are about activating musical memory. They are about continuing the unending struggle to uphold and to experiment with 
folklore-that is, with deeply rooted Afro-Caribbean expressive traditionsand to ground creative experimentation in the fertile soil of that folklore.

\section{POSTSCRIPT}

Grupo did it again: they blew people away. The long-awaited November 1, 2008, concert at Hostos Community College left the packed auditorium enthralled and demanding more. From all appearances, the crowd was indeed comprised of the salsa sophisticates one would expect at a Grupo reunion concert over thirty years later: mainly New York Puerto Ricans and African Americans who had lived and loved Grupo since way back when, in the salsa seventies, and were in the know about the special, inimitable quality that Grupo stood for in the Latin music firmament of those years and ever since. Call them "Grupomaniacs," but they hung on every note, recognized the tunes from the first chord, and, while fully present before the newly constituted group, found themselves collectively wafted back to an earlier period in their sonic lives. This must be what Eddie Palmieri had in mind when he was talking about "revisiting" a great and indelible cultural moment.

Eddie himself had other obligations that night and was unable to take part. So though still on the agenda, the new, Grupo version of "Muñeca" will have to await future opportunities. There were other unexpected changes of plan as well, the most notable of them occasioned by the passing away of the great Orlando "Puntilla" Ríos in August. The loss was profound, throughout the AfroLatino musical and spiritual community and of course for Grupo, where his role and sheer presence in its new incarnation have been central. But in the Hostos concert, held in Puntilla's memory, Grupo demonstrated the wisdom of their guiding concept of improvisation: in facing this and other challenges, they were able to replace the irreplaceable by once again adapting their format and building on new strengths. The young Afro-Cuban drummer, singer, and dancer Pedrito Martínez joined the group in Puntilla's unexpected absence and surpassed the hopes of all but those who already knew of his inspirational talent in all three capacities. His strong presence throughout the concert was no doubt one of the highlights of the evening.

Another surprise was the participation of the veteran Puerto Rican vocalist Israel Berríos, who was a vocalist in Arsenio's band in New York during the 1950 and 1960 and musical director of the New York-based son group Son de la Loma in subsequent years. He captivated the audience with his renditions of a bolero and a danza and of course served as lead voice in "La Gente del Bronx," 
which brought the proud hometown crowd to its feet. In recognition of the largely Nuyorican audience, the group decided to bring back the plena from its first album, "Adelaida," with its irresistible and hilarious chorus "Si me pego en el pool (yo me caso contigo)" (If I hit the lottery (I'll marry you)). ${ }^{6}$ Originally performed by the early New York plena group Victor Montañez y Sus Pleneros de la 110, the lead was assumed in this 2008 rendition by the young Nuyorican drummer and singer Alex Lasalle, and his vibrant energy and powerful voice electrified the hall.

As Grupo Folklórico II moves forward and aspires to a longer life span than the first time around, the principle of descarga continues to guide the project in all its aspects. Even the shifting personnel and repertoire go to illustrate the group's inherent ability to be flexible, its commitment to improvisation. What amazes and delights even the musicians themselves is performing these complex and demanding musical compositions without arrangements and without even a set plan for any given execution. With Grupo, unlike in the other bands they lead or play with, it is arrange as you go, within each tune and in the lineup of songs and even musicians on any given occasion. Confident musicianship is of course a prerequisite to such flexibility and open-endedness and to such a free hand with the musical traditions. But as Jerry González and his startling jazz-guaguancó rendition of two Pedro Flores standards, "Obsesión" and "Perdón," demonstrated perhaps more powerfully than anything else on that already historic November 1 evening in the South Bronx, Grupo is, by its very nature and in its founding concept, about resisting and refusing formula and standardization. It is steeped in traditions, from bolero to rumba guaguancó, but those traditions might be interwoven among themselves and laced through, in this case, with Gerry's signature Miles Davis-sounding muted horn. Grupo is faithfully folkloric and boldly experimental Nueva York style.

In our times, perhaps even more than the mid-197os, when Fania Records was taking salsa in a strongly commercial, formulaic direction, there is a need for that alternative idea of what "salsa" is about and to restore it to its improvisational intentions, to that delicate balance between tradition and innovation that Grupo stands for by definition. La Perfecta showed the way and opened the door to this new stylistic practice back in the 1960s, at the threshold of salsa history, and the "Eddie Palmieri Alumni Band," Grupo Folklórico y Experimental Nuevayorquino, upheld and continued that alternative musical concept and practice as salsa's heyday was beginning to wane. Today, La Perfecta II and Grupo II, as revisited by their original proponents, are once again holding the line against the rampant standardization and dilution of that rich musical 
legacy. Salsa memory is about tapping history and reinstating descarga to the center of Afro-Latino musical expression.

\section{Notes}

The authors would like to thank Kwami Coleman for his contribution to this essay.

1. González, interview, 115.

2. Rondón, Book of Salsa, 96.

3. René López discussed the relation of the founding of Grupo to this resistance to Fania in his June 28, 2008, interview on the Washington DC radio show Latin Flavor. In personal conversation in September 2008, Nelson González told me that Grupo was sometimes referred to as "el cuco de la Fania," the haunting spirit, as it were, of the powerful record label.

4. I differ here with the interpretation offered by Rondón, who claims that "the salsa boom had indirectly affected the group, poisoning its folk music and its experimentation" (Book of Salsa, 248).

5. López, interview.

6. The phrase "me pego en el pool" refers to the betting pool in bolita, based on the horse races. This line was unfortunately improperly translated in the English version of Rondón's Book of Salsa (on p. 242, it reads, "if I win at pool”).

\section{Bibliography}

González, A. Interview. In SalsaTalks, ed. Mary Kent. Altamonte Springs, FL: Digital Domain, 2005.

Rondón, C. M. The Book of Salsa. Chapel Hill: University of North Carolina Press, 2008. 


\title{
Epilogue: Performing Memories_-The Atlantic Theater of Cultural Production and Exchange
}

\author{
CARROLL SMITH-ROSENBERG
}

Rhythms of the Afro-Atlantic World emerges out of a conference, "Rhythms of the Atlantic World: Rituals and Remembrances," held at the University of Michigan in the spring of 2005. Conference participants explored the ways the peoples of the Atlantic turned to music, dance, and religious rituals to express their experiences of crossing and recrossing that ocean of tears and misremembering: not only their sorrows and fears, but also their resilience and resistance to oppression, the joys they took from life and love, the desires that drove them. Scholars from Brazil, West Africa, Europe, the Caribbean, and the United States reported on the gestures, rhythms, bodily movements, and song patterns that followed often reluctant travelers from Iberia to the Cape Verde Islands, from Senegal and the Bight of Biafra to Bahia and Surinam, and thence across the Caribbean to New Orleans, Charleston, and New York-and, at times, back again. Sessions described how, through song and dance, Atlantic peoples performed barely remembered traditions, stories of worlds they had never known and their hopes for unseen futures. Papers reported on conflicting elements in Trinidadian and Brazilian carnivals; the movement of Jews displaced from Spain and Portugal to Senegal and the transformation of their musical traditions within the Afro-Jewish communities they formed there; the flow of architectural forms from Senegal to Portugal to Brazil, of ritual dances from West Africa to Guiana to syncratic fusion churches in the Bronx-or, counterclockwise, from Africa to Cuba and Brazil and down to Argentina, where they assumed the tango's many-layered forms. At all times, conference participants asked about memories and transfigurations, how distant origins surfaced as 
suppressed pentimentos, unconscious vestiges embodied in muscle memories, speech patterns, and rhythmic gestures. The conference was interdisciplinary, transregional, and transnational. Rhythms of the Afro-Atlantic World has selected presentations that focus on contemporary music, dance, and religious rituals, especially as they figure Afro-Atlantic interconnections and the complex ways cultural performances connect the local to the global. The volume's underlying concern is with the ways cultural performances create sites of AfroAtlantic political agency and empowerment. In all these ways, the conference represented the particular vision of the University of Michigan Atlanticists.

Who were the scholars who made up Michigan's Atlantic community, the individuals who imagined "Rhythms of the Atlantic" and brought it into existence? Some of us had long-standing connections with the University's Latin American and Caribbean Studies Program, others with the Center for African and African American Studies, still others with the American Culture Program, which included in its commodious folds Native American, Latino, and Arab American studies, or with the History and English Departments, with their strong foci on African, U.S., Caribbean, and European history and literature. We reached out, as well, to the Law School, to draw in colleagues connected with an international research and teaching project, "The Law in Slavery and Freedom," as well as to fellow researchers at Michigan State University. Many of us drew our inspiration from diasporic and race studies, from examining the impact that the Middle Passage, chattel slavery, peonage, and racial discrimination had on the formation of contemporary Atlantic cultures and politics. Others focused on the impact of colonialism on indigenous and exploited peoples around the Atlantic and on their patterns of political and cultural resistance, still others on comparative emancipation studies. Some of us were drawn by literary historian Joseph Roach's vision of a circum-Atlantic world formed and transformed through cultural performances as varied as jazz funerals, Mardi Gras, and theatrical performances. "The circum-Atlantic world," as Roach imagined it, "insists on the centrality of the diasporic and genocidal histories of Africa and the Americas, North and South, in the creation of the culture of modernity." "While a great deal of the unspeakable violence instrumental to this creation may have been officially forgotten," he explained, "circum-Atlantic memory retains its consequences, one of which is that the unspeakable cannot be rendered forever inexpressible."' Only partially-forgotten memories repeatedly resurface in circum-Atlantic music, dance, theater, and religious rituals. Reembodiments of the past, reinventions of the unsuccessfully repressed, they substitute present creativity for past traumas. ${ }^{2}$ Crossing national and ethnic di- 
visions, densely layering inherited forms with current experiences, they come together to create an "oceanic interculture."3

The object of Michigan's Atlantic Studies Initiative was to interweave our disparate perspectives; to encourage discussions and team teaching among Latin American, Caribbean, British, and African historians, anthropologists, and literary critics; to open the borders constraining U.S. history within landlocked confines. We offered courses on comparative indigeneities, comparative slaveries, revolutions, and empires; the material Atlantic; and sexualities and the discourses of modernity. Out of our discussions and interdisciplinary courses, a multilayered vision of a circum-Atlantic world emerged, a vision that was, at times, conflicted and contradictory, but always open-ended and interdisciplinary. We insisted on positioning the South (Africa and South America) and the twin archipelagos of the Cape Verde Islands and the Caribbean at the center of our vision of Atlantic studies. We repeatedly explored the Atlantic's relation to modernity, to modernity's origins in the fifteenth and sixteenth centuries as well as to the postmodern world of global capitalism. Europe's exploitation of the natural resources and rich lands of the South, we argued, its penetration of the sub-Saharan gold trade, its seizure of gold and silver from Mexico and Peru, its trade in the addictive crops of Brazil and the Caribbean (sugar, coffee, chocolate, and spices) and in the most revolutionary commodity of all, human bodies from the Americas and Africa, greatly enriched European economies, stimulating the commercial and industrial revolutions. Long before textile factories fouled the air of Lancaster and Manchester, modern industrial systems developed on and across the Atlantic: on British and Dutch trading vessels, where, as Peter Linebaugh and Marcus Rediker argue, large numbers of men, subject to harsh, industrial disciple, "cooperated on complex and synchronized tasks ... subordinated to mechanical equipment"; on the large-scale plantations of Brazil, Surinam, and the Caribbean, where sugar was not only grown but refined and where the bodies of field hands constituted the systems' movable parts. ${ }^{4}$ The Atlantic's economic revolutions, partnered with its political revolutions, produced the first modern republics (the United States and France) and the first postcolonial independent nations (the United States and Haiti) - along with that ultimate expression of political modernity, the affirmation of man's inalienable right to life, liberty, and happiness. This last point should not surprise us. Liberty and slavery wound around one another in the circum-Atlantic world, for, as Toni Morrison argues, liberty cannot be imagined except in opposition to chattel slavery. ${ }^{5}$ Inspired by eighteenth-century declarations of the rights and equality of man, new indepen- 
dent republics took form across Latin America in the early nineteenth century. Political modernity stepped forth upon the world stage.

To these economic and political themes, others of us of brought a cultural studies concern with performance-not only literal performances, as in music or dance, but also performances of the most inner sense of self. Turning to the proliferating literatures of the early modern and modern eras, we sought evidence of the emergence of modern subjectivities, the decentered subject dependent on others for her/his sense of self. While Hegel did not formulate his master/slave conundrum until the late eighteenth century, we found examples far earlier, in Prospero's dependence on Calliban and Crusoe's on Friday. Others of us looked at the fragmented Caribbean subject as she emerged in Jean Rhys's novels and the rootless, centerless subject depicted so differently by Claude McKay and Nella Larsen. At the same time, we invited Brazilian artists to display their work, listened to Caribbean poets, watched the films of Isaac Julian and Sembene Ousmane. In short, we sought the origins of the modern cosmopolitan subject in the flow of circum-Atlantic literature and performance.

Always, we insisted on seeing the circum-Atlantic as a whole, never ignoring the centrality of Africa to the Atlantic experience, at the same time as we refused to divide the Atlantic into a Black Atlantic and a Western Atlantic centered on struggles between indigenous Americans and European imperialists. Such a division would inevitably marginalize African diasporic peoples and cultures in Latin America and indigenous Americans in the Caribbean. Most seriously, it would ignore the ways their systemic exploitation by Europeans were interrelated-as were the oppressed's efforts at resistance. Indeed, precisely what intrigued us was the interaction of peoples and cultures-and modes of oppression-around and across an Atlantic that was at all times black, red, and white. Organizing conferences and exchanging and commenting on one another's papers, we worked to refine a University of Michigan vision of the Atlantic world and Atlantic culture. Rhythms of the Afro-Atlantic World exemplifies this vision-at the same time as it expands and enriches it.

Insisting on the dynamic flow of cultural forms and traditions from West Africa to Brazil, Haiti, Cuba, New York, Paris, and back again, Rhythms of the Afro-Atlantic World inscribes the circum-Atlantic as a theater of cultural exchange and production. In tracing these movements and transformations, it insists on the critical importance of the body's sensuality in linking past memories to present creativity, building on a long-standing tradition in black Atlantic studies that stretches from W. E. B. Du Bois, through Alain Locke, Langston Hughes, Claude McKay, Aimé Césaire, and Leopold Sédar Senghor, to Paul 
Gilroy and current musicologists. Not only does Rhythms insist on the vital interconnectedness of cultural performance and political enactments; in doing so, it problematizes the traditional division of global and local.

Pointing to Afro-Atlantic communities' active participation in the transformation of African cultural traditions into new cultural forms through the appropriation of modern technologies, Rhythms of the Afro-Atlantic World problematizes not only the local/global binary but our understandings of tradition and hence of modernity itself. As explained by Senegalese dancer/choreographer Germaine Acogny (the subject of one of the essays in Rhythms), "tradition is not ... a sleeping lake but a sea with waves coming and bringing new things." For half a millennium, African cultural forms have been dispersed and reformed across the diaspora-disrupted, disempowered, and reassembled during colonization. Commodified, born aloft on radio signals and Internet connections, they have returned to Africa, where, yet again, they are being reappropriated, transformed, and politicized. Swirling around the circum-Atlantic, Afro-Atlantic cultural forms refuse the dichotomies of local/global and traditional/modern-just as Rhythms of the Afro-Atlantic World refuses the dichotomy of cultural/political. This is the complex, multilayered and interactive vision Rhythms holds up to its readers. Like Afro-Atlantic cultural performances, Rhythms links traumatic and resistant memories to current creativity and political agency. Refusing to forget, it forges new directions.

\section{Notes}

1. Joseph Roach, Cities of the Dead: Circum-Atlantic Performance (New York: Columbia University Press, 1996), 4.

2. Ibid., 2.

3. Ibid., 4.

4. Marcus Rediker and Peter Linebaugh, The Many-Headed Hydra: Sailors, Slaves, Commoners, and the Hidden History of the Revolutionary Atlantic (Boston: Beacon, 2000), 150 .

5. Toni Morrison, Playing in the Dark: Whiteness and the Literary Imagination (New York: Vintage, 1993).

6. Interview with Ralph Lemon, April 2009, Program Notes, "Fly: Five First Ladies of Dance," May 30/31, 2009, 651 Arts, New York. 



\section{Contributors}

\section{EDITORS:}

Mamadou Diouf is Leitner Family Professor of African Studies at Columbia University, Middle East and Asian Languages and Cultures and History Departments, and Director of the Institute of African Studies. He has taught at the University of Michigan, Ann Arbor, and the University Cheikh Anta Diop in Dakar (Senegal) and served as Director of the Research Program at the Council for the Development of Social Science Research in Africa (CODESRIA). His research focuses on urban and cultural studies; performance studies; and citizenship in West Africa, Senegal in particular. He has published and edited numerous articles and books, including Le Kajoor au 19 $9^{\text {ème }}$ siècle: Pouvoir Ceddo et Conquête Coloniale (1990) and Une Histoire du Senegal: Le Modèle Islamo-Wolof et ses périphéries (2001) and coedited (with Mara A. Leichtman) New Perspectives on Islam in Senegal: Conversion, Migration, Wealth, Power, and Femininity (2009).

Ifeoma Kiddoe Nwankwo is currently Associate Professor of English at Vanderbilt University. She specializes in comparative analyses of U.S. African American and Caribbean literature and popular culture (including that from the Hispanophone Caribbean and the circum-Caribbean portions of Central America). She is author of Black Cosmopolitanism: Racial Consciousness and Transnational Identity in the Nineteenth-Century Americas (2005), editor of African Routes, Caribbean Roots, Latino Live (a special issue of the Journal of Latin American and Caribbean Ethnic Studies), and founding director of Voices from Our America ${ }^{\mathrm{TM}}$, an international public scholarship project. Nwankwo's articles and reviews have appeared in American Literary History, Radical History Review, and Callaloo, among other venues. Topics have included U.S. African American-Latin American/Latino relations; the mechanics of memory in bicultural, bilingual Black communities; and the politics of intraracial translation. For her work, Dr. Nwankwo has been awarded fellowships from the Ford Foundation, the DeWitt Wallace Foundation, and the Woodrow Wilson National 
Fellowship Foundation. She taught at the University of Michigan from 1999-2006 and co-directed the University of Michigan Atlantic Studies Initiative from 2004-2006.

\section{CONTRIBUTORS:}

Melvin L. Butler is currently Assistant Professor of Music at the University of Chicago. After studying performance and jazz composition at Berklee College of Music (BM Cum Laude 1993), he pursued graduate degrees in Jazz Studies and Ethnomusicology, earning his PhD (2005) from New York University. Based on fieldwork among Pentecostal Christians in African Caribbean and African American communities, his doctoral dissertation examined the dynamics of musical experience, national identity, and religious practice in Haiti, Jamaica, and New York City. Butler has presented his research at meetings of the Society for Ethnomusicology, the Inter-American Conference on Black Music Research, the International Association for the Study of Popular Music, and other venues. His published articles and reviews have appeared in Ethnomusicology, Journal of the American Academy of Religion, Black Music Research Journal, Current Musicology, Journal of Popular Music Studies, and Current Musicology. In addition to receiving a Fulbright IIE field research grant (2002), Butler is the recipient of a Ford Foundation Predoctoral Fellowship (1999-2003) and was the 2004-5 Thurgood Marshall Dissertation Fellowin-Residence at Dartmouth College.

Yvonne Daniel is Professor Emerita of Dance and Afro-American Studies at Smith College and was a Rockefeller Fellow at the Center for Black Music Research, 2005-6. As a dance artist and musician, she has performed, choreographed, and taught Caribbean dance for over thirty years. As a scholar, she has done fieldwork in Haiti, Cuba, Brazil, Suriname, and Martinique, and she presents her findings both at academic conferences and in community settings. She has published two books, Rumba: Dance and Social Change in Contemporary Cuba (1995) and Dancing Wisdom: Embodied Knowledge in Haitian Voudou, Cuban Yorumba, and Bahian Candomblé (2005), and over twenty articles, chapters, encyclopedia entries, and reviews and has edited four documentary videos on Caribbean dance and African American religions. Dancing Wisdom won the de la Torre Bueno Prize given by the Society of Dance History Scholars.

Juan Flores is Professor of Latino Studies in the Department of Social and Cultural Analysis at New York University. He teaches, lectures, and writes about Puerto Rican and Latino culture, theories of culture and popular culture, diaspora studies 
and transnational community, Latino literature and music, and Afro-Latino culture and history. His book publications include Poetry in East Germany, Divided Borders, La venganza de Cortijo, From Bomba to Hip-Hop, The Diaspora Strikes Back, and Bugalú y otros guisos. He is the translator of Memoirs of Bernardo Vega and Cortijo's Wake (El entierro de Cortijo) by Edgardo Rodríguez Juliá, and he is a coeditor of On Edge: The Crisis of Contemporary Latin American Culture and the Blackwell Companion to Latina/o Studies. He won the Casa de las Américas Prize in 1980 for his essay Insularismo e ideología burguesa and in 2009 for Bugalú y otros guisos, and in 2008 was honored with the Latino Legacy Award from the Latino Center at the Smithsonian Institution. Flores serves on a range of advisory and editorial boards and is a founding member of the Afrolatin@ Forum.

Susan Leigh Foster is Professor in the Department of World Arts and Cultures at the University of California, Los Angeles. Choreographer, dancer, writer, Foster began presenting concerts of her own work in 1977. Since that time she has created several solo concerts that she has toured in the United States, Canada, and Europe. Her publications include Reading Dancing: Bodies and Subjects in Contemporary American Dance (1986), Choreography and Narrative: Ballet's Staging of Story and Desire (1996), and Dances That Describe Themselves: The Improvised Choreography of Richard Bull (2003).

Deidre R. Gantt is an adjunct English faculty member at Prince George's Community College in Largo, Maryland, where she serves as the faculty adviser for Reflections Literary and Arts Magazine. She holds an MFA in creative writing from Emerson College and a BA in sociology from the University of Southern California. Her research interests focus on the communicative functions of creative arts in communities and nations throughout the African Diaspora, with an emphasis on the interplay between shared traditions and local customs. She has been published in several literary journals and anthologies, including Brilliant Corners: A Journal of Jazz and Literature and Gathering Ground: A Reader Celebrating Cave Canem's First Decade. Most recently, she has been writing and performing poetry over go-go, jazz, gospel, and Caribbean musical forms.

René López is an internationally acclaimed authority on Afro-Cuban and U.S. Latin music. His work as a producer, collector, and educator on the subject has resulted in a foundational contribution to public knowledge about these influential cultural fields. Lopez has worked closely with such major musical innovators as Arsenio Rodriguez, Eddie Palmieri, Israel “Cachao” Lopez, Chucho Valdez, and many others. 
His accomplishments have been acknowledged by the Smithsonian Institution, Jazz at Lincoln Center, and various cultural institutions in Cuba and Puerto Rico.

Patricia van Leeuwaarde Moonsammy, Assistant Professor and Distinguished Chair of Africana Studies at Dickinson College, received her PhD in Anthropology from the University of Michigan in 2009. Her scholarly interests lie at the intersection of expressive culture, social activism, and the politics of representation and subjectivity in the Caribbean and throughout the African Diaspora. With funding from the National Science Foundation and the University of Michigan's Center for World Performance Studies, she spent two and a half years conducting fieldwork in Trinidad and Tobago, exploring the dynamic relationships that exist between people of African and South Asian Indian ancestry and documenting how these relationships are expressed through performance. Her dissertation, Rapso Warriors: Poetic Performance, Revolution, and Conscious Art Music in Trinidad and Tobago, employs performance analysis and oral history to document the evolution and politics of rapso, a genre of music whose practitioners advocate for social justice.

Halifu Osumare has been involved with dance and African American culture internationally for over thirty years as a dancer, choreographer, teacher, administrator, and scholar. She is a 2008-9 Fulbright Scholar for Ghana, West Africa; holds a $\mathrm{PhD}$ in American Studies from the University of Hawai'i at Manoa; and has a BA in dance and an MA in the ethnology of dance. Currently, she is Associate Professor of African American Studies at the University of California, Davis, and she was a member of the dance faculty of Stanford University from 1981 to 1993. She has published extensively on global hip-hop, including her book The Africanist Aesthetic in Global Hip Hop: Power Moves (2007).

Deborah Smith Pollard is Associate Professor of English Literature at the University of Michigan, Dearborn. Her research centers on contemporary issues in gospel music like the praise and worship movement, the changing dress code, and holy hip hop. Her publications include her book, When the Church Becomes Your Party: Contemporary Gospel Music (Wayne State University Press, 2008), which was named a Michigan Notable Book for 2009, as well as articles in academic journals like the Arkansas Review: A Journal of Delta Studies, Womanist Theory and Research, CEA Critic, and the CLA Journal. Since 1994 she has been the host and producer of Strong Inspirations on FM $98 \mathrm{WJLB}$, the Detroit area's top rated urban station. In 2005 she was named Gospel Announcer of the Year during the 2oth Annual Stellar Music Awards, often called “The Grammys” of Gospel. From 1983 to 2004, she produced 
two of the country's largest free outdoor gospel festivals, Detroit's McDonald's GospelFest and the Motor City Praisefest, and from 2002 to 2006, she was the Director of the African and African American Studies program at the University of Michigan, Dearborn.

Millery Polyné is Assistant Professor of American Studies at New York University's Gallatin School of Individualized Study. Polyné is a historian of the African Diaspora in the Americas, and his research interests and publications highlight U.S. African American and Afro-Caribbean cultural, political, and economic initiatives in the 19th and 2oth centuries. A former Frederick Douglass Postdoctoral Fellow at the University of Rochester, Polyné has published several peer-reviewed articles in Caribbean journals, including Caribbean Studies and Wadabagei. He is the author of From Douglass to Duvalier: U.S. African Americans, Haiti, and Pan Americanism, 1870-1964 and is working on a second project that examines the cultural politics of race, space, and urban memory in Boston, Massachusetts.

Raquel Z. Rivera is a writer and Affiliated Scholar of the Center for Puerto Rican Studies at Hunter College. She coedited an anthology with Deborah Pacini Hernandez and Wayne Marshall entitled Reggaeton (2009). Her book New York Ricans from the Hip Hop Zone was published in 2003 and is already in its fifth printing. Her academic articles on popular culture have been published in various books and journals. As a freelance journalist, she has been published in numerous magazines and newspapers, including Vibe, One World, Urban Latino, El Diario/La Prensa, Hoy, San Juan Star, El Nuevo Día, Claridad, and Diálogo.

Carroll Smith-Rosenberg is the Mary Frances Berry Collegiate Professor, Emeritus, University of Michigan. She is the author of This Violent Empire: The Birth of an American National Identity; Disorderly Conduct: Visions of Gender in NineteenthCentury America; and Religion and the Rise of the American City, in addition to numerous articles. She is presently at work on a book-Constituting Atlantic Citizenship: Race and Citizenship/Universalism and Exclusion in the Age of Revolution. She is the recipient of scholarly awards from the Guggenheim Foundation; the Institute for Advanced Study, Princeton; the Ford Foundation; the Rockefeller Foundation; the American Council of Learned Societies; Center for the Study of Ideas and Society, University of California. She founded and directed the Atlantic Studies program at the University of Michigan and is currently director of the Atlantic Studies at The Graduate Center, City University of New York. 
Lucía M. Suárez is Associate Professor of Spanish at Amherst College. Born in Spain of Cuban parents in transit to their new life in the United States, she has been shaped by, and is deeply committed to, transatlantic studies. Her research and work have taken her around the world to places such as Brazil, Cuba, the Dominican Republic, Haiti, and France. She is the author of The Tears of Hispaniola: Haitian and Dominican Diaspora Memory (2006) and the coeditor (with Ruth Behar) of The Portable Island: Cubans at Home in the World (2008). Suárez has written articles and reviews on dance, human rights, and Caribbean literatures and film, which have appeared in the Journal of Haitian Studies, World Literature Today, Callaloo, and Latin American Literary Review, among other volumes. A Ford Foundation Fellow, she is currently writing her book Seeking Democracy through Dance: Afro-Bahian Dance Traditions, \& Cultural Agency.

Umi Vaughan is an artist and experimental ethnographer who explores dance, creates photographs, and publishes various works about African Diasporic culture. He has conducted extensive anthropological research in Cuba about Afrocuban music and dance and has created numerous scholarly presentations, art exhibits, and cultural events in the United States and abroad. He holds a PhD in Cultural Anthropology from the University of Michigan, and his photographic work has been commissioned for the permanent collection of Alameda County and the City of Oakland, California $(2007,2008)$. He is currently Assistant Professor of Africana Studies at California State University, Monterey Bay. In Fall 2008 he introduced an exciting new course called Afro Cuba Hip Hop: Music and Dance in the Black Atlantic, in which students explore the social history and actual practice of music/ dance styles from throughout the African Diaspora. 


\section{Index}

Abakuá dances (Cuba), 23-24

Acogny, Germaine, 10, 122-27, 130-33, 134ng

Acosta, Leonardo, 238, 248

Adams, Yolanda, 42

Adejunmobi, Moradewun, 169

African

dance aesthetic, 121-33, 134n17, 146-47

diaspora. See diaspora

hip-hop, 12-13, 161-76

oratory, 59-60

African American

church, 55, 59-65, 67, 69, 71

hip-hop, 8, 12-14, 161-68, 170, 173-76, 221,228

identity, 122, 127, 130, 144-45

Pentecostals, 47, 51

Africanhiphop.com, 165-68

Africanist aesthetic, 162, 164, 170, 174-75, $176 \mathrm{n} 2$

Africanist Aesthetic in Global Hip-Hop: Power Moves, The (2007), 162

African People's Socialist Party, 173

Afro-American Folksong: A Study in Racial and National Music, 3

Afrolution Records, 161

AIDS, 112

Ailey, Alvin, 122, 129-30

Ainsi parla l'oncle (So Spoke the Uncle), 143

Akan symbols, 175

Alegre All-Stars, 258

Ali, Muhammad, 68, 70

Alkire, Helen, 126

allmusic.com, 62

Alma Moyó, 185-92, 194
Alternative Dimensions Concert, 226

Álvarez, Adalberto, 243-46

Alvarez, Henny, 259-60, 262, 263

Alvin Ailey American Dance Theatre, 115

American Negro Ballet (1937-39), 146-48

Anan, Kofi, 172

Anderson, Benedict, 100

Andrade, Mario de, 105

Andrade, Oswald de, 97, 101

anthropophagy (Brazil), 9-10, 97, 101, 112

Appadurai, Arjun, 95, 108

Araiz, Oscar, 100

Arará dances (Cuba), 23-24

Arciniegas, Manuela, 189-90, 193, 195

Argentina, 100, 103-4, 118n18

Armenteros, Chocolate, 259-61, 263

Ashanti, Kariamu Welsh, 122

Associated Negro Press, 148

Augustin, Papa, 145

Austin-Broos, Diane J., 52

Australia, 124

Babenco, Hector, 109

Bacardi beach, Cuba, 21

Bahamas, 23

Baker, Houston, 4

Balanchine, George, 122

Balbuena, Bárbara, 246

ballet, 10, 100, 114, 123-29, 145-50, 187

Ballet du Vingtieme Siecle (Brussels), 125

Bal Nègre (1946), 144

Banco Popular, 182

Baraka, Amiri (Leroi Jones), 3, 234

Barnett, Claude, 148-49

Barón del Cementerio (Baron of the Cemetery), $188-89$ 
Barton, Halbert, 183-84, 193-94

batá drumming (Cuba), 30

batarumba (Cuba), 30-31

Bausch, Pina, 102

Bawon Simityè, $188-89$

Beatty, Talley, 127

Beauchamps, Pierre, 124

Beenie Man, 50-51

Béjart, Maurice, 125-26

Belo Horizonte, Brazil, 98-99, 102, 104-5, 113-14

Benítez-Rojo, Antonio, 249

Benjamin, Walter, 99

Bennett, Andy, 164-65

Bennett, Robert, 5

Berríos, Israel, 266-67

Berthoz, Alain, 132

Bethune, Mary McLeod, 144

Bezerra de Mello, Yvonne, 110-11

Bible Break (album), 62

Bicentennaire Exposition Internationale, 144

Biggham, Milton, 63

Bilby, Kenneth, 41

Birth of African-American Culture, The, 6

Black Arts Movement, 130

Black Atlantic: Modernity and Double

Consciousness, The, 4

Black Entertainment Television (BET), 42

Blackman, Garfield. See Lord Shorty

Blackman, Sheldon, 215-19, 223-24, 226-28, $230 n 6$

Black Nationalism, 227, $231 \mathrm{n} 17$

Black Noise, 165

Black Pentecostalism, 60

Black Power Revolution (1970s), 220

"Black Semantics," 61

Black Uhuru, 173

Blackwell, Scott, 62

Blaine, Vicki, 126

Blaxploitation films (1970s), 174

"Blood Spilla," 67

"Blow 'Way" (song), 219-20

blues, $58,167,175$

BMG 44, 167-68

bomba, 12, 178-95, 196n 40

and Alma Moyó, 185-92, 194

and "maroon" aesthetic, 185-88 nationalizing and transnationalizing, $181-85$

three "cultures" of, 182

Bonne, Angel, 236

Book of Revelation (Bible), 68-69, 73n56

Borges, Lô, 104-5

"Boul Fale" (song), 170

Bourdieu, Pierre, 10, 121

Boyer, Horace C., 61

Branch, William ("Duce") ("The Ambassador"), 56-57, 65, 67

Brant, Fernando, 101-4

Brathwaite, Edward Kamau, 6, 170

Brazil, 2, 9-10, 19, 29, 37n33, 79-80, 83-84, 86, 89-90, 95-119

and artists, 112-13

the body, 108-15

and citizenship, 95-96, 111, 113-15

as colonial country, 105

and dance, $105-8$

and modernity, 97-99, 112-15

national identity, 95-97, 103-4, 108

national unity, 100

and violence, 95-96, 102, 109-10, 115

See also anthropophagy; Corpo

Cidadão; Grupo Corpo

Brazilian Candomblé, $8,80,87-88$

Breakaway online magazine, $62,72 \mathrm{n} 33$

Breaking New Ground, 227

Brierre, Jean, 137, 145

Brother Book, 220, 223, $230 n 16$

Brother Resistance, 216-20, 222-23, 226-28, 231n16, 231n19

Brown, Chuck, 200-202, 205-7, 210

Buena Vista Social Club, 23

Buenos Aires, 100, 103-4

Bureau d'Ethnologie, 143, 150-51

Bus 174, 10, 109-12

Bush, George W., 21, $230 n 16$

Busta Rhymes, 166

Butler, Uriah ("Buzz"), 219, 227

Byron, Cheryl, 221

Cabrera, Lydia, 83

Cadilla, María, 181

Caesar, Shirley, 61

Caími, Nana, 104

Caldeira, Teresa, 109

Caldwell, Robert G., 142 
call-and-response, 8, 13

Calvary Baptist Church (Salt Lake City), 66

calypso, 13, 200, 202, 203-5, 208, 214-16, 220-21, 223, 225-26, 228, 229n4, 23onn6-7, 23on13, 231n18, 231n27, $231 n 34$

Calypso at Dirty Jim's, 205

Calzado, David, 236, $250 n 1$

Canada, 21, 25

Canclini, Néstor García, 96, 115

Candomblé. See Brazilian Candomblé

Cannon, Poppy, 153n12

Capá Prieto, 192

Caribbean, 6-7, 12, 21, 95

Caribbean Cultural Center (NYC), 178-79

Caribbean New Yorkers, 12, 178-95

Carnival (Trinidad), 200, 202, 204-5, 208-9, 214-20, 224-29, 231n27

Carpenter, Bill, 62

Carter, Paul, 124

Casanella, Liliana, 240-41, 245

Cashless Society, 162

Cash Money Crew, 162

casino dancing (Cuba), 30-31

Castriota, Leonardo Barci, 98

Castro, Fidel, 22-23

Catholicism, 139-41

Cepeda, Margarita ("Tata"), 186-87

Cepeda, Modesto, 183-84, 186

Césaire, Aimé, 4

Channel O, 165, 171

chants, 82-84

Chile, 103-4

choreography, 121-35

Christian rap music, 8, 55-71. See also holy hip-hop

Church on the Rock (Kingston, Jamaica), 44-45

chutney soca music, 225

cimarron (runaway) existence, 31

Cimber, Alphonse, 145

Cinco de Mayo, 79-80

cities, 97-99, 108-15

Cities and Citizenship (1999), 108

citizenship, 95-96, 108-9, 111, 113-16

civil rights movement, 8,55

"clap-hand" choruses, 7, 42 cold war, 136-37

Collazo, Julito, 263

Colombia, 223

colonialism, 2, 4, 15n3, 22, 82, 89, 91n10, 97-98, 102-5, 109-10, 116n 4, 123-27, 129, 131, 133n6, 133n8, 137-38, 143, 154n34, 163, 167, 172-73, 180, 182-83, 185, 201, 204-5, 214, 217, 219-22, 227-28, 229n1, 23on4, 234-37, 247, 249-50, 25on4, 250n14, 270-73

communism, 104, 136-37, 243

Concepts in Unity (1975), 256-57, 260

Conjunto Anabacoa, 257

Conjunto La Perfecta, 256-57, 259-62, 265

Conjunto Libre, 262

connective marginality, 12, 163-65, 174-76

consumerism, 96, 107-8, 115, 165

"contact zones," 116n4, 133n8

Contemporary Christian Music (CCM), 62

Cooder, Ry, 23

Coolio, 171

Cooper, Carolyn, 170

Corbin, Jon, 66

Corpo Cidadão, 10, 96, 102, 113-14

corporeal memory, 10-11

Cortés, José Luis, 249

Courlander, Harold, 89

Cross Movement (CM), 56, 65-71, 73n56

Cross Movement Ministries, 65

Cross Movement Records (CMR), 65, 58, 65

Crouch, Andrae, 58-59

Crystal Rose Records, 58

Cuba, 2, 6-8, 12, 14, 19-36, 36n1, 37n33, 37n35, 79-80, 83-84, 86, 88-9o, 92n17, 181, 234-5o, 250n14, 251n19, 252n40, 252n42, 252n56, 253n58, 257. See also Cuban dance; Cuban tourism

"Cuba Linda" (song), 259-60

Cuban dance, 19-36, 88, 92n17, 246-47 as "cultural capital," 23 effects of, 32-34 and "experiential authenticity," 29-30 and film, 23 and international students, 26-28, 35 


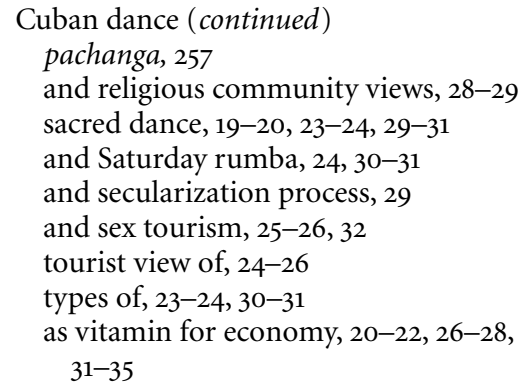

See also orichas; salsa; timba dance

Cuban Ministry of Culture, 22-23

Cuban Revolution (1959), 26, 30, 35, 248

Cuban rumba, 24

Cuban tourism, 19-36, 36n1

and dance. See Cuban dance

and education, 21-23

and international students, 21-23, 26-28, 35

sex tourism, 25-26, 32

U.S. ban on, 21-22

Cuban Yoruba, 8, 23-24, 30, 36n1, 8o, 83, $86-89,237-38,244,252 n 56$. See also orichas

Cunningham, Merce, 102, 129

Dafora, Asadata, 142

DaMatta, Roberto, 109

"Damba Yaribe" (song), 181

dance, 1-11, 85-89, 96, 105-8, 123-33, $134 \mathrm{n} 17,136-55$

African dance aesthetic, 121-33, 134n17, 146-47

and cultural circulation, 8

and divinity, 85-86

emotion, and spectacle, 105-8

and feelings of "groundedness," 4, 123-24

and improvisation, $127-31$

memory, 10-11

and national identity, 96

and perceptual theorists, 132

and resistance, 121-23, 131-33

and rhythm, 87-89

and slavery, 127

and tourism. See Cuban tourism

Western, 124-25

See also danse folklorique Haïtienne; muscle memory; "stored knowledge"; timba dance; unison movement

dancehall, 7, 14, 42, 46, 49-51, 54n8, $146-47,170,180$

dance memory, 10-11

danse folklorique Haïtienne (Haitian folkloric dance), 9, 136-55

Danzón, 252n40

Davis, Carlene, 50

Davis, Gerald, 60

Debord, Guy, 107

DeFrantz, Thomas, 122

Delany, Martin, 4

Delgado, Issac, 241, 245

de Mille, Agnes, 146-47

de Pradines, Emerante, 148

descarga principle, 262, 267-68

Dessalines, Jean-Jacques, 144

Destiné, Jean Léon, 137-45, 148, 151, 154n31, 154nn34-35

Destiny's Child, 64

Development of Creole Society in Jamaica, The, 6

diaspora (African), 2-9, 12, 14, 15n7, 41, $44-45,54 \mathrm{n} 8,55,59,8 \mathrm{o}-87,128,152$, 167-68, 176n2, 179-81, 184-87, 190-92, 195, 210, 221, 246

and bomba, 181, 184-87

and New York, 179-81

Diawara, Manthia, 167, 174-75

Dieul, Dieuf, 169

District of Columbia Home Rule Act of 1973, 205

Dixon-Gottschild, Brenda, 121-22

Dja-Rara, 178

DJs, 46, 54n8, 62, 66, 72n28, 208

Dockett, Kymo, 66

Dominican Republic, 12, 178-80, 185, 187-94, 195n7

Donnie McClurkin: Live in London and More (2000), 44-49

Douglass, Frederick, 3

"downpressed," 231n19

drumming, 13, 81, 84-87, 125, 145

"buried mathematics" of, 84-87

polymetric, 13

and tratao, 85

Du Bois, W. E. B., 3-4, 172, 272

Dudley, Shannon, 200 
Duncan, Isadora, 128, 151

Dunham, Katherine, 115, 127, 129-30, 137, 140, 142-50, 155nn46-47

Duprey, Awilda Sterling, 187

Ecole des Sables, 125, 130

Egypt, 167

Elegbara, 79, 90

El Médico, 241-43, 245-46

El Nuevo Día newspaper, 184

Emancipation Day, 225, 227

“embodied knowledgeS," 80, 89-90

eschatology, 68

Escuela Nacional de Arte (ENA), 236, $251 \mathrm{n} 20$

Estimé, Dumarsais, 136, 144

ethnology, 84

ethnomusicology, 13, 83

"experiential librarians," 81-89

Failde, Miguel, 252n4o

Fania Records, 257-58, 262-63, 267, 268n3

Fantasia, 59

Favela Rising, 112

Fernández, Ruth, 183

Ferreras, Salvador E., 183

Feuillet notation, 129, 133n6

Figueroa, José, 178-80, 194

Finland, 25

Fischer, Sibylle, $153 \mathrm{n} 10$

Five Percent Nation, 55

"flip the script," 162, 164-65, 170

Flores, Pedro, 267

Fon-based dances, 24, 86, 89

Ford Foundation, 142

Foreman, Murray, 169

Formell, Juan, 245-46

Foucault, Michel, 10, 121

France, 25, 123, 127, 130, 133n6, 143, 145, 163,169

Franklin, Aretha, 59

Franklin, Kirk, 42, 47, 63-65, 68, 72n 42

Freyre, Gilberto, 105

"Fun in the Son" gospel festival (Jamaica), 50

Fussman-Mathon, Lina, 140-41, 153

Gabao Hip-Hop Festival (Gabon), 161 Gambia, 161
Garcia, Destra, 204

García, Willie, 259, 262-63

Garvey, Marcus, 218-19, 222-23, 227

Gayelle, 215

Gelewsky, Rolfo, 100

genege music, 171

George, Iwer, 204, 232n34

George, Nelson, 202

Georgia Mass Choir and Gospel Music Workshop of America, Inc., 63

Ghana, 175

Gibson, James, 132

Gilroy, Paul, 4, 100, 272-73

Glimpses of Haiti, 150

Glissant, Edouard, 3

globalization, 2, 6, 8, 10, 14-15, 114, 165

Godreau, Isar P., 182, 184

God's Trombones, 59

Go-Go Coalition, 209-10

Go-Go Crankin: Paint the White House Black, 206

go-go music, 13, 200-210 and audience participation, 207-8 as the people's music, 200-203 and the Trinidadian identity, 203-5 and the Washington, DC, identity, 205-8

Golden, Gene, 263

Goler, Veta, 122

González, Andy, 258-60, 262-63

González, Celina, 31

González, Guido, 263

González, Jerry, 258-59, 262, 265, 267

González, Nelson, 262-63, 265

González, Neris, 240-41, 245

Good Neighbor Policy, 136, 142

"gospel blues," 58-59

Gospel Gangstaz (holy hip-hop), 62

gospel music (African American), 7, 41-50, 58-59, 61-63

and evangelism, 62

and "holy hip-hop," 61-63

"intoned" style of sermonizing, 44

notable figures in, 59

transnational spread of, and radio, 42

See also McClurkin, Donnie

gospel reggae (Jamaican), 7-8, 42, 45-53, $54 \mathrm{n} 8$

Gospocentric Records, 63 
Gottschild, Brenda Dixon, 169

G-Praize Music, 58

Graburn, Nelson, 27

Grace Thrillers, 50

Graham, Martha, 102, 125, 128, 142, 149

Graham technique, 125

Great Britain, 172-73, 202, 203-4, 214, $230 n 15$

"the Great Commission," 67

Green, Al, 59

Grenada, 223

"groundedness," 4, 123-24

Grupo Corpo (Brazilian dance company), 9, 96-97, 99-102, 104-5, 107-8, 112-16, 117 n16

Grupo Folklórico y Experimental Nuevayorquino, 256-67, 268n3

Grupo Folklórico II, 267-68

Guilbault, Jocelyne, 229n4

Guillén, Nicolás, 237

Gutiérrez, Juango, 191

Habermas, Jürgen, 98

Haiti, 8-9, 12, 19, 29, 79, 83-84, 86, 89-90, $115,128,136-55,180-81,188-94$

art, 138-39, 150

as bridge, 180

and Catholicism, 139-40

folkloric dance. See danse folklorique Haïtienne

and Kreyòl, 181

music, 178

national identity, 139-40, 151-52

tourism, 136-39

U.S. occupation of (1915-34), 137, 139

See also Haitian Vodou

Haitian Academy of Folklore and Classic Dance (HAFCD), 149-50

Haitian folkloric dance. See danse folklorique Haïtienne

Haitian Revolution (1791), 87, 192

Haitian State Tourist Office, 145

Haitian Vodou, 8-9, 19, 80, 87-88, 128, 137-40, 147-51, 181, 188, 193

and lwas, 87, 181, 193

yenvalu dance, 88

and zombie films, 137

Haiti Dance, 149

Haiti Sun, 145, 151
Haiti Tourist Information Bureau

(HTIB), 136-37

Haiti Week of New York (1951), 136-37, 145

Hammond, Fred, 42

Hartman, Saidiya, 127, 134nn11-13

Hawkins, Edwin, 58-59

hedonism, 12-13

Hernández, Oscar, 258, 262-63, 265

Herrion, Steven ("Bugs"), 207

hip-hop, 8, 12-14, 42, 55, 161-76, 176n17, 221, 228

African, 12-13, 161-76

African American, 8, 12-14, 161-68, 170, 173-76, 221, 228

Kenyan, 170-74

Latino, 163

Senegalese, $168-70$

underground of, $176 \mathrm{n} 17$

"Hip-Hop Globe," 162

Hip Hop Parliament, 171-72

Holland, 171

Holston, James, 95, 108

Holt, Grace Sims, 60

holy hip-hop (HHH), 47, 55-71, 72n41

and Black preacher style, $59-61$

cultural and historical links, 58-61

and gospel, 61-63

lyrics, $67-71$

and the mainstream, 63-65

and performance, 66

terminology, $56-58$

See also Cross Movement

Horst, Louis, 149

Hostos Community College (NYC), 265-66

House of World Cultures (Haus der Kulturen der Welt) (Berlin), 263-64

Hughes, Langston, 3, 143-44, 272

Humphrey, Doris, 128

Hurricane Ivan, 223

Hurricane Katrina, 210

IBEX nightclub, 209

identity, 41, 44-49, 96, 122, 203. See also national identity

Ilú Ayé, 193

improvisation, 125-31, 164, 203, 240, 246, $249,261-62,266-67$ 
In Search of Africa, 174

Indian Arrival Day, 225

Indian music, 200, 204, 208-9

Instituto Superior de Arte (ISA), 236, 251020

invisibility, 110-11

I Walked With a Zombie (1943), 137

Jackson, Michael, 64

Jai, Rikki, 227

Jamaica, 22-23, 41-54, 173, 221, 227

"Fun in the Son" gospel festival, 50

identity expression through gospel music, 44-49

and "Spring Breakers," 49-50

See also Jamaican Pentecostals; reggae

Jamaica Gleaner, 49-50

Jamaica Hotel and Tourist Association, 50

Jamaican Pentecostals, 7-8, 41-44, 47-54

and African American culture, 42-44

dress code, 51-52

gospel festival, 50

and gospel music, 42-44

and gospel reggae, 51-53

and "Jamaicanness," 48

and Jamaica of yesteryear, 43

Jamaican Protestants, 42

Jamaica Tourist Board, 50

Jamoo rapso, 215-16, 230 6 6

Japan, 21, 25, 163

Jay-Z, 56, 167

jazz, 3, 58-59, 127-28, 134n17, 146-47, 167, 175

Jerkins, Rodney (“Darkchild”), 64

Jim Crow segregation, 146

Joachim, Paulin, 15n 3

Johnson, James Weldon, 59

Jones, Elias, 202

Judson Church group, 122

Junkyard Band, 207

Kalamashaka (K-shaka), 12, 170-71, $173-76$

Kalunga Neg Mawon, 191, 194

Kaos and Mystro, 57

"kapuka," 171

Kenoly, Ron, 50
Kenya, 2, 161-62, 166-68, 170-74

hip-hop, 170-74

Kenya African National Union, 173

Kenyatta, Jomo, 173

Kibaki, Mwai, 171

Kidd, Michael, 149-50

Kikuyu ethnic group (Kenya), 171

Kingston, Jamaica, 42, 44-45

Kisskidee, 226

Klauss, Vianna, 100

Knight, Brian, 202

Knowles, Beyonce, 59

Kongo-Angola Palo dances (Cuba), 23-24, 30, 89, 91010

Kongo-Bantu languages, 181

Krehbiel, Henry Edward, 3

Kreyól, 12, 188-89, 193

KRS-One, 166

Kumina, 41

Kuti, Fela, 202

labor movements, 13-14

Laboy, Niko, 193

La Casa de la Música (April 2003), 242

La Charanga Habanera, 245, 250 n1

Lafayette Theatre (Harlem, NY), 146

Laguerre, Michel, 83

Lane, Jason, 202

La Perfecta II, 256-57, 265, 267

Lasalle, Alexander, 185-86, 188-89, 192-95, 196n30, 267

Lataillade, Vickie Mack, 63

Latin America, 10, 12, 25, 95, 98-99, 103-4, 108

Latinidad, 12, 192

Latino, the term, 178-79

Latino hip-hop, 163

Latin soul, 180

La Troupe Folklorique Nationale, 144, 148

La 21 División, 191

Laurenti, Jean Noel, 133n6

Layne, Lancelot ("Kebu”), 13, 219-21, $230 n 13$

"Lay This Body Down" (song), 189

Leitão, Júlio, 115

Leite, Carlos, 100

LeoGrande, William, 21-22

Lescot, Élie, 139 
Lévi Strauss, Claude, 98

Liberia, 174

Limón, José, 102

Lindy, 128

Linebaugh, Peter, 271

Locke, Alain, 3, 272

Lo Dice Todo (1976), 256

London, 44-45

López, René, 14, 259, 262-63, 265, 268n3

Lora, Osvaldo ("Bembé"), 193

Lord Shorty, 200, 204, 215, 220, $230 n 6$

Lornell, Kip, 200-201, 209

Los Pleneros de la 21, 191

Lost Boyz, 171

Los Van Van, 241, 246

Louis XIV, 124-25

Love 101 FM (Jamaica), 42, 45

Lull, James, 165

Lund, Kátia, 109

Luo ethnic group, 177

Lycée des Jeune Filles, 148

Maal, Hamet, 169

Magloire, Gérarde, 143, 150

Magloire, Paul E., 136, 138, 152n5

Makeba, Miriam, 168

Malawi, 161

Maldonado, Jorge, 263

Malone, Jacqui, 122

Mandela, Karega, 222, 227

Mango Island record label, 168

Manifesto antropófago (1928), 101

Manifesto da poesia Pau-Brasil (1924), 101

Manning, Susan, 129

Manolito y Su Trabuco (timba band), 236

marginalization, 108, 112, 161-65

Marks, Morton, 83

Marley, Bob, 48

Maria Maria, 10, 96, 100-105, 108, $118 \mathrm{n} 18$

"maroon," 185-88, 234-50, $250 n 3$

defined, $250 n 3$

Martí, José, 237

Martí, Virgilio, 259-63

Martin, Randy, 100, 106

Martínez, Pedrito, 266

Martins, Marilene, 100

Mary Mary, 63-64
Mason, J. Alden, 181

Mason, John, 83

materialism, 12-13, 55

Le Matin, 139

Mau Mau uprising (Kenya), 172

Mberam, Nickson, 172

McClendon, Lisa, 58

McClurkin, Donnie, 42, 44-49, 54n 4

McIntyre, Diane, 10, 122-23, 126-33, 134n16-17

McKay, Claude, 3, 272

MC Lida, 168

MC Solaar, 168

Meirelles, Fernando, 109

Meralla, Emir García, 245

Merrique, Ozzie, 227, 232n34

methodology, 1-15, 269-73

Mexico, 21-23

Middle Passage, 3, 59, 103, 127, 170, 270

Midnight Robber, 220, 226, 228

Mintz, Sidney Wilfred, 6

Miranda, Wander Melo, 98

modern dance, 10, 96, 100, 108, 114, 123, 126-30, 142, 145, 149, 151-52, 155n41, 155n 54,187

Modernism and the Harlem Renaissance, 5

modernity, 4-5, 9, 10-11, 97-99, 112-14, 149, 153 n10

Montano, Machel, 204

Montego Bay, Jamaica, 44, 49-51

Mont-Rosier, Régine, 150

Moore, Robin, 238

Moré, Benny, 236, $251 n 19$

Morrison, Ingrid, 5

Morrison, Toni, 271

Motown, 258

Moulin, Nelly, 111

Mount Olivet and Riversdale Pentecostal Church, Jamaica, 48-49, 53

Mowatt, Judy, 50

MTV Africa, 164

Mudra Afrique, 125-26, 130

"Muñeca" (song), 265-66

muscle memory, 10-11, 81, 122

music, $1-15,15 \mathrm{n} 7$. See also gospel music; gospel reggae; hip-hop; holy hip-hop; reggae; rhythm and blues 
music mafia (Trinidad and Tobago), 226

"Mwe Ale" (song), 193

Nascimento, Milton, 101, 104

Nascimento, Sandro, 109-11

National Association for the Advancement of Colored People (NAACP), 142, 153n12

National Ballet of Senegal, 126

National Day of Rapso, 216

National Folk Festival in Washington, DC, 141-42

national identity

Brazilian, 95-97, 103-4, 108

and dance, 96

Haitian, 139-40, 151-52

Trinidad and Tobago, 214

Trinidadian, 203-5, 208

Nation of Islam, 55

Nazareth, Ernesto, 102

Nazario, Luis Alvarez, 181

N'Dour, Yousou, 168

Nelson, Jill, 206

Nettleford, Rex, 149

"Never Surrender" (song), 222

New Negro, The, 3

News of Haiti, 137

New York bomba, 178-95

New York City Opera, 144

NG La Banda, 240, 244, 246, 249

Nigeria, 167, 171

Nijinsky, Kyra, 149-50

Ni Wakati, 171

Nkrumah, Kwame, 172

Noguet, Pedro ("Único"), 192

Nommo, 59

nongovernmental organizations

(NGOs), 113-14

North African Arabs, 163

Norwood, Dorothy, 61

Le Nouvelliste, 143

Nu Nation Project, The (album), 63

Nurse Allende, Lester, 184-85

Nyasuma, Mamadi, 202-3

Obeah (1940), 146-47

O Clube da Esquina, 104-5

Odinga, Raila, 171

Ohio State University, 126
Old Ship of Zion, 60

O Projecto Sambalelê, 113

Oquendo, Manny, 258-59, 262-63, 265

Orange Democratic Party, 171

orichas, $7,20,26,30,36 \mathrm{n} 1,83,85,87$, 244

Orozco, Danilo, 240

Ortiz, Fernando, 1, 84, 235

Osumare, Halifu, 122

OzyMajic, 227, 232n34

P. Diddy, 167

pachanga, 257

Padmore, George, 172

Palmieri, Eddie, 256, 262, 265-67

Pa' lo Monte, 179, 191

Pan-Africanism, 125-26, 172-73, 219

Paris, Arthur, 60

Patasar, Mungal, 227

Paul, the apostle, 67

Paulo F.G., 241, 248, 250 1

Peace, Michael, 62

Peaceoholics, 209-10

Pederneiras, Miriam, 100, 113-14

Pederneiras, Paulo, 100

Pederneiras, Pedro, 100

Pederneiras, Rodrigo, 100-102, 105

Pedroso, César, 236, 247, 253n 58

Pee Froiss, 167

Pelican Inn (Trinidad), 215-19, 228-29

Pentecostalism (Jamaican), 41-54

People's National Movement, 204, 230n15

Pereira, Vilma, 111

Phanatik (Brady Goodwin), 65

Pierrot Grenade, 220, 226, 228

Piñeiro, Ignacio, 251n19

Pinn, Anthony B., 58, 71n2

Pinochet, Augusto, 103

Pitts, Walter, 60

plena, 183, 191-92

Pocket, The, 206

polyrhythm, 164, 175, 201, 203-4, 206-7, 210,240

Popular Music and Youth Culture (2000), 164

Portugal, 82, 91 1nio

Positive Black Soul (Senegal) (PBS), 12, $167,168-71,173,175$

poverty, $108-13$ 
Pratt, Mary Louise, 116n4, 133n8

Pressing, Jeff, 203, 210

Price, Richard, 6

Price-Mars, Jean, 140, 143, 150

Primus, Pearl, 127, 129, 142, 247

privatization, 108

"proprioceptor" nerve, 132

Public Enemy, 57-58

Puerto Rico, 11-12, 178-95, 235, 257. See also bomba

Pure Flava/Pure Gospel, 58

Purri, Carmen, 100, 118n19

Queen Afrik, 168

Queen Latifah, 168

Quiroga, José, 248

Q-Unique, 179

Raíces (2001), 182-83, 193

Ramsey, Kate, 139

rapso, 13-14, 214-32

audience participation, 215

ideology of, 222-24

and the music industry, 224-26

and revolution, 215-21

and survival, 226-29

Rapso Explosion, 226

RapsoFest, 227

Rapso History Month, 216, 227

Ras Shorty I. See Lord Shorty

Rastafarianism (Jamaica), 41, 48, 55, 218-19, 222-23, 231n23

Rediker, Marcus, 271

Reed, Teresa L., 58

reggae, 7-8, 45-49, 52, 170. See also gospel reggae

Re-Loaded, 215, 223, 226

Rennie, Bukka, 209

repetition, 13, 107, 203

"reterritorialization," 165, 169, 175

Revival, 41

“The Revolution" (song), 64-66, 68, $73 n 45$

rhythm, 4, 8-9, 79-92. See also chants; dance; drumming; polyrhythm; unison movement

rhythm and blues (R\&B), 8, 42, 46, 48, $55,58-59,64,73 n 60$

"Rhythms of the Atlantic World: Rituals and Remembrances" conference, 269-73

Rigal, Nieves Armas, 247, 252n56

"Ring de Bell," 215-19, 222

Rio de Janeiro, Brazil, 19, 104, 109-10, 112

Ríos, Oscar ("Puntilla"), 263, 266

Rituals (recording company), 226

ritual singing, 85

Rivera, Angel Quintero, 234, 237

Roach, Joseph, 121, 270

Roberts, Roger, 224

Robeson, Paul, 143-44

Rocha, Castro, 97, 117n7

Rockefeller, Nelson, 142

Rockefeller Foundation, 142

Rock It Right (album), 62

Rodrigues, Jose, 259, 261-62, 265

Rodríguez, Abraham, 263-64

Rodríguez, Arsenio, 236, 251n17, 252n42, 260, 264-65

Rodríguez, Ernesto, 189, 192, 194, 197n42

Rodríguez, Frankie, 258, 262

Rodríguez, Tito, 257

Roederer, J. C., 203

Rogers, Barry, 262

Rogers, J. A., 3

Rondón, César Miguel, 258

Roosevelt, Eleanor, 154n36

Roosevelt, Franklin D., 136, 142

Ros, Lázaro, 31

Rose, Doudou Ndiaye, 169

Roy, Maya, 235

Rubalcaba, Gonzalo, 237

rumba, 12, 24, 186-88, 193, 196n4o, 235-38, 240-41, 247-48, 259-60, 267

Russia, 163

Sá, Anderson, 112

Sadre-Orafai, Stephanie, 221

salsa, 14-15, 30-31, 180, 257-60, 262, 265-68

and descarga principle, 262, 267-68

Salt-n-Pepa, 65

Salvador, Brazil, 19

samba, 97, 112

Sambo figure, 127

San, Papa, 50, 66

San Elías (Saint Elijah), 188-89

Sant-Anna, Sérgio, 104 
São Paulo, 104

Savain, Roger, 145

Savoy Ballroom era, 128

Schechner, Richard, 229

Schieffelin, Edward, 215

Schwarz, Roberto, 101

Senegal, 2, 10, 12, 121, 123, 125-26, 130, 162, 167-70, 173

hip-hop, $168-70$

See also Positive Black Soul

Senghor, Leopold Sédar, 4, 125, 134n9, 272 sermonphone, 61

Sete ou oito peças para um ballet, 102, 106-7

Settereld, Valda, 126

sex tourism, 25-26, 32, 97

Shell, $117 \mathrm{n} 16$

Shiffai, $167-68$

Shuffle Along (1945-46), 146

"Sicamá Moyó," 185, 196n30

simaran, 234-35

singing, 82-84

Sissle, Noble, 146

ska, $7,42,48$

Slave Dance, 144-45

slavery, 1, 3-4, 8, 15n7, 31, 59, 82, 102-3, $109,115,127,164,270-72$. See also diaspora; Middle Passage

Smith, Tim, 61-62

Smith, Wayne, 21

Smitherman, Geneva, 59, 61

Smithsonian Folklife Festival (2008), 256, 263-64

Soares, Luiz Eduardo, 110

soca, 13, 200-206, 208-10, 214-15, 220, 224-26, 228, 230 n6

Soca Monarch (2007), 204-5

Sokolow, Anna, 126

Solana, Obanilú Iré Allende, 190

Sommer, Doris, $116 \mathrm{n} 2$

son, 236-40, 246, 251n19, 252n45, 264, 266

Son de la Loma, 266

songs, 3, 58, 82-84

soul jerkers, 60

Soul Searchers, 202, 205

Souls of the Black Folk, The, 3

Soul II Soul, 5

Soul-to-Soul tour, 175

Sounds in Motion, 126, 130

South Africa, 161-62, 165, 167, 171
Spain, 21, 82, 91n10, 202

Spanish Town, Jamaica, 42

"spectacular society," 107-8

spellbinders, 60

Spiritual Baptist religion, 219, 221, 225, $230 n 12$

Spiritual Shouter Baptist Liberation Day, 225

Stephenson, Charles C., Jr., 200-201, 209

Still, William Grant, 144

Stitchie, 50

"Stomp" (song), 63-65

"stored knowledge," 8-9, 81

Straight Up Go-Go (1992), 202

Sublette, Ned, 3, 250n1

sub-Saharan Africa, 175

Sugar Hill Gang, 61

Sweden, 25, 171

Switzerland, 25

SWV (Sisters with Voices), $73 n 60$

Tamaris, Helen, 149-50

Tanzania, 168, 172

Taylor, Diana, 122

Tee, Doug E., 168

theater, 106

Thompson, Robert Farris, 122, 180

3canal, 224, 226-27

3 canal Show, The, 226

Tico All-Stars, 258

timba ("maroon music") (Cuba), 13, 14, 30-31, 234-50

context of, $248-49$

dance, $246-47$

definitions of, 235-37

lyrical content, $241-46$

musical style of, $237-41$

timba dance, $246-47$

Timberland boots (Timbs), 66

Tonex, 63

Tonic, The (John Wells), 65, 67

Torres, Carlos (“Tato"), 181

Tratao, 85

Trini Bashment, 227, 232n 34

Trinidad, 2, 12-13, 181, 200-210, 214-29, 229nn1-2, 23on7, 23on15, 231n23

and abductions, 223

national identity, 203-5, 208

See also Carnival 
Trinidad and Tobago, 13-14, 204, 214, 216-20, 223-29, 229n2, $230 \mathrm{n} 15$

and music mafia, 226

national identity, 214

and the term Black, 23on15

Tristes Tropiques, 98

Troubled Island, 144

Trouillot, Michel-Rolph, 140, 152n 5

T.R.U.-L.I.F.E. (Virgil Byrd), 65

Truman, Harry S., 154n36

Turner, Ike, 175

Turner, Tina, 175

Turner, Victor, 112

Uhuru Movement, 173

Ukoo Fani Mau Mau, 172

Último Trem, 100

unison movement, 79-80, 88-89, 90n1

United Nations, 172

United Pentecostal Church (UPC), 53-55

United States, 2, 12-13, 23, 25, 164. See also gospel music

University of Michigan, 269-73

Unsung Heroes, 167, $231 \mathrm{n} 17$

U.S. Congress, 205

Valdez, Merceditas, 31

Varadero, Cuba, 21

Velez, eDDie, 57

Venegas, Eddie, 263-64

Verger, Pierre, 83

Victor Montañez y Sus Pleneros de la, 110

Villa-Lobos, Heitor, 102

Vincent, Sténio, 139, 153n26

Virgin Islands, 12, 181

Vitier, Jose Maria, 31

vodou. See Haitian Vodou

Voeks, Robert, 83

Voices of East Harlem, 175

Von Grona, Eugene, 146-47
Wald, Elijah, 5

Walker, Hezekiah, 50

Warner, Keith, 204

Washington, DC, 140-42, 200-210

Washington Post, 206

Weheliye, Alexander G., 3, 5

Wenders, Wim, 23

West, Kanye, 56

West Africa, 9, 15n3, 137-38, 141, 143, 151, $164,168,170,202$

Western Mirror, The, 49

Western music, 4, 164

"What a Friend We Have in Jesus" (song), 44

White, Walter, 142, 153n12

White Zombie (1932), 137

Wiley, Stephen, 62

Williams, Eric, 204, $230 n 15$

Williams, Kimberly (Kiwi), 58, 62, 66, 70

Williams, Lavinia, 137-38, 145-51, 154n39, 155n 47

Wilson, Danny, 57

Wilson, Jason ("Maji"), 57-58, 66

Wilson, Olly, 202, 207

Winans, Marvin L., 47

Wolof slang, 169-70

Word, Sound, Power, 227

World War II, 143

Wray, Cheryl, 65

Wright, Richard, 4

X, Malcolm, 172-73, 219, 227

Yarborough, Lavinia Williams, 87

Yelvington, Kevin, 137, 150

Yuinon, The, $57-58$

Zervigón, Eddie, 263-64

Zimbabwe, 161

Zimbalist, Jeff, 112

zombie films, 137 